\title{
The Story of the \\ New England \\ Whalers
}

John R.Spears 


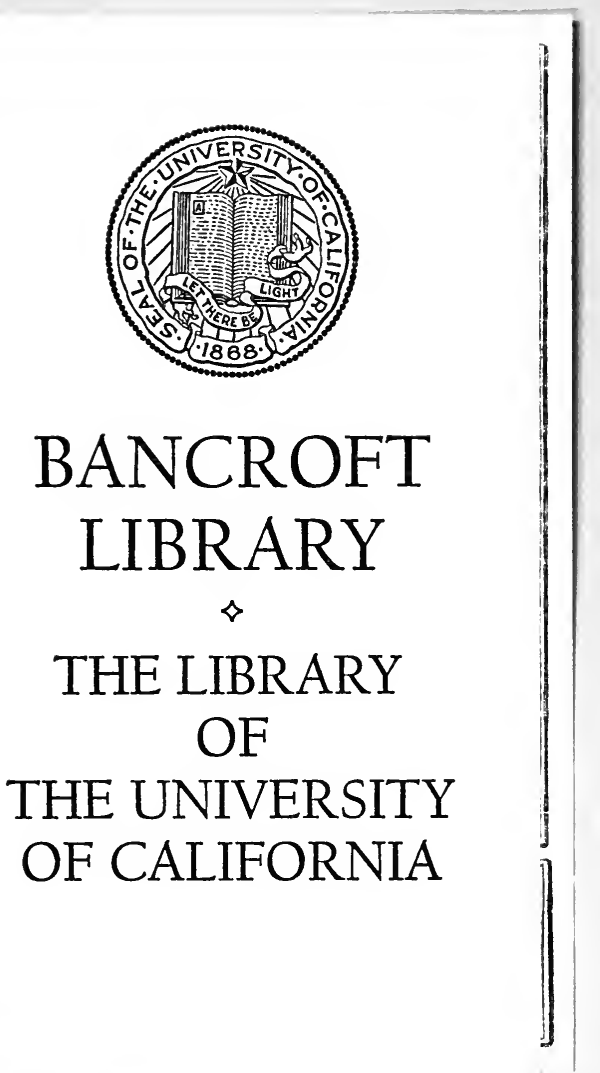


Digitized by the Internet Archive in 2007 with funding from Microsoft Corporation

http://www.archive.org/details/storyofnewenglan00spearich 


\section{THE STORY OF}

THE NEW ENGLAND WHALERS 


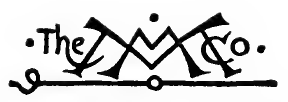

\section{THE MACMILLAN COMPANY}

NEW YORK - BOSTON - CHICAGO ATLANTA - SAN FRANCISCO

MACMILLAN \& CO., Limited LONDON - BOMBAY - CALCUTTA MELBOURNE

THE MACMILLAN CO. OF CANADA, LTD. TORONTO 


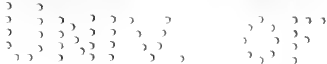

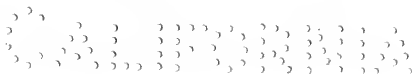




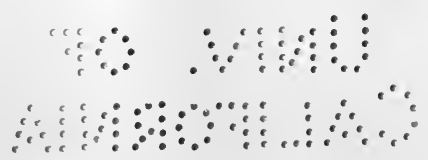

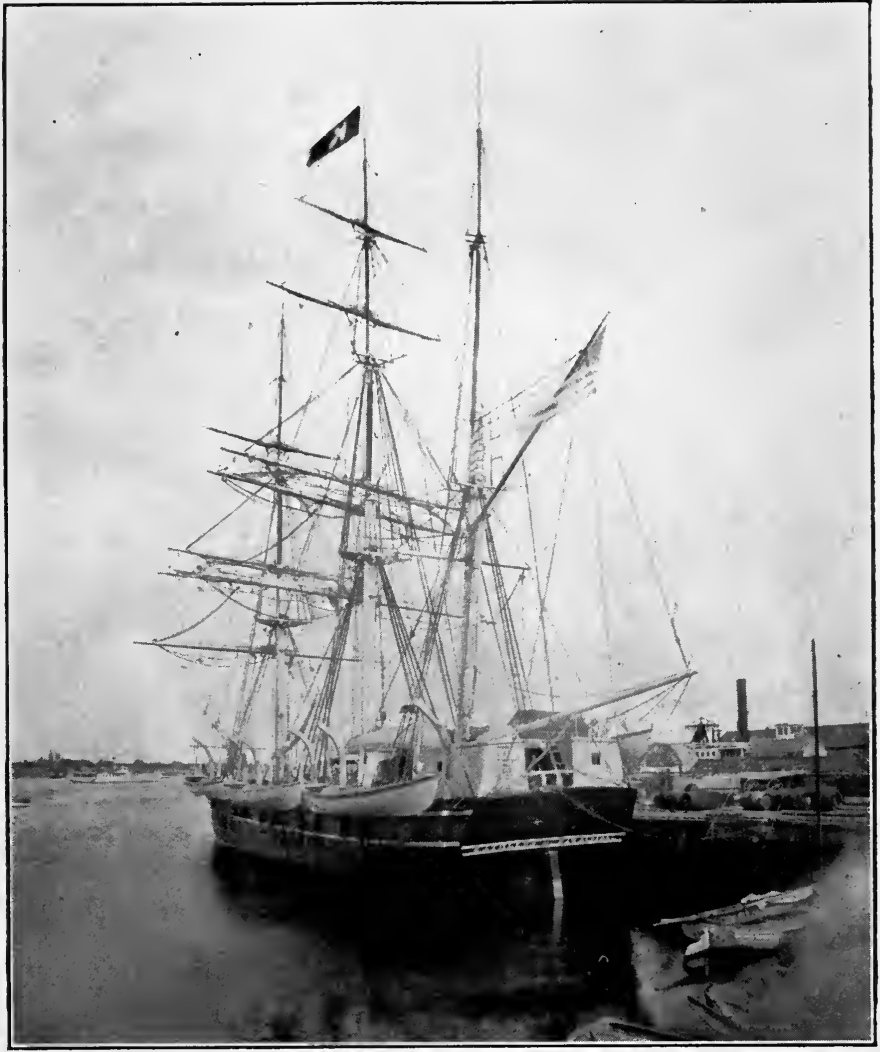

Ready to Sail 


\title{
THE STORY OF
}

\section{THE NEW ENGLAND WHALERS}

\author{
BY \\ JOHN R. SPEARS
}

New Wark

THE MACMILLAN COMPANY

1910

All rigbts reserved 


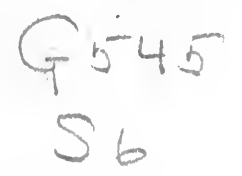

\section{MISTORY}

COPYRIGHT, I908,

BY THE MACMILLAN COMPANY.

Set up and electrotyped. Published September, rgo8. Reprinted September, rgro.

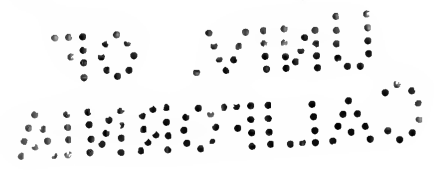

\section{Norwood Press}

F. S. Cusbing Co. - Berwick Eั Smitb Co. Norwood, Mass., U.S.A. 


$$
63603
$$

\section{To}

ALL WHO PULL TO THE TUNE OF

"A DEAD WHALE OR A STOVE BOAT"

4.8581. 


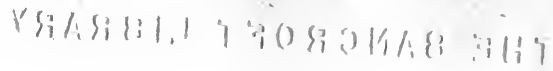




\section{CONTENTS}

CHAPTER

I. Samuel Mulford, Alongshore Whaler • I

II. Told of the Red Indian Whalers • . 18

III. EARly Days on Nantucket • • $\quad 38$

IV. The Minor Colonial Ports • • . 73

V. Nantucket in the War of the Revolution 85

VI. A Long Period of Depression • • • 97

VII. Adventures of the Explorers - • - 123

VIII. Whales as the Whalers knew Them • 159

IX. Harpoons, Lances, Guns, and Boats • . 203

X. Sketches Afloat with the Whalers • 244

XI. Work of the Fighting Whales • • . 286

XII. Whaling as a Business Enterprise • 312

XIII. The Mutineers and Slavers • • . 340

XIV. Tales of Whalers in the Civil War

XV. In the Later Days • • • • • 394 


\section{LIST OF ILLUSTRATIONS}

Ready to sail

Trying out blubber on deck $\quad$. $\quad$. $\quad$ : $\quad$. 68

Towing whales to the Onondar Fiord trying house, Iceland $\quad . \quad . \quad . \quad . \quad . \quad . \quad . \quad 128$

Off for a two years' cruise . . . . . 160

Sperm whaling - The chase . . . . $\quad$ I 88

Entangled whale diving • • . . 226

Cutting in a whale. $\quad$. $\quad$. $\quad .276$

Ships receiving the captains, officers, and crews of aban-

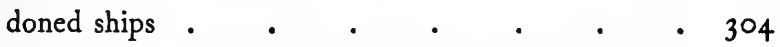

View of the Stone Fleet which sailed from New Bedford,

November 16, 1861 $\quad$. $\quad . \quad$. $\quad . \quad$. 384

Abandonment of the whalers in the Arctic Ocean, Sep-

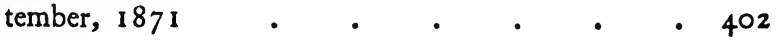





\section{I}

SAMUEL MULFORD, ALONGSHORE WHALER

A $T$ a meeting of the inhabitants of Easthampton, Long Island, held on November 6, I651, "It was ordered that Goodman Mulford shall call out ye town by succession to loke for Whale."

"Goodman," as the reader will remember, was not a given name but a title that was applied to citizens who were not of the aristocracy. "Goodman" Mulford had been christened John. $\mathrm{He}$ was of the peasantry, but the fact that he was chosen to the office mentioned shows that he was a man of influence in the community, and of tried impartiality as well.

Restless Englishmen from the settlements on Massachusetts Bay had scattered themselves along the coasts to the south and west, and crossing Long Island Sound (the first purchasers numbered 


\section{The Story of the New England Whalers}

thirty-five), they had formed a settlement at the easterly end of Long Island as early as 1640 .

Long Island was a goodly country in its soil and climate. Prodigious crops of wheat could be raised, and prodigious crops of truck are yet raised there. And what was of more importance to this story, the sea, just off the dune-lined beach, was a natural feeding ground for whales at certain seasons of the year.

The pioneers on Massachusetts Bay, with their followers, seem to have had some knowledge of the whale fishery. When the Mayflower had anchored inside of Cape Cod, the Pilgrims observed that "large whales of the best kind for oil and bone came daily alongside and played about the ship. The master and his mate and others experienced in fishing preferred it to the Greenland whale fishery." Because of the number 'of whales seen there some of the Pilgrims wished to settle on the cape rather than go on in search of another location, for they had come to establish a fishing colony as well as in search of "freedom to worship God."

As the products of the whale formed an impor- 


\section{Samuel Mulford, Alongshore Whaler}

tant source of income to the first settlers on Massachusetts Bay, the prospectors who came to Long Island to spy out the land looked away across the surf, as well as at the soil in the clearings the Indians had made; and seeing the familiar spout of the right whale out at sea confirmed them in the good opinion of the locality which an inspection of the soil had already given them. Moreover they learned from the Indians that "drift whales," namely, those that had died from natural causes, were often to be found on the beach.

It is manifest from the records that the whale fishery was prosecuted on Long Island almost from the first day the settlers arrived. In March, r644, the settlers divided themselves into four wards of eleven persons each to attend to the drift whales cast ashore, and it was voted that, when such a whale was found, "Every inhabitant, with his child or servant that is above sixteen years of age," should share equally in the products, save only as two men who were appointed to cut up the carcass were to have two shares each.

The active work of hunting live whales was carried on at the Long Island settlement after a 
4 The Story of the New England Whalers

fashion that had already been established on Massachusetts Bay. Boats fit to launch through the surf were built by the community, and, with the necessary implements, these boats were held in readiness to go in pursuit of any whale that might be seen offshore. To make sure that every whale that came near the beach would be seen it was necessary to keep some one constantly on watch alongshore. To give such lookouts a wide range of vision the settlers erected among the dunes a number of tall spars, fitted with wooden pins up which the lookouts could climb, with perches or seats at the top. Further than that, a well-thatched hut was built, here and there, near the beach to serve as a shelter from heavy storms; for the whales "struck in" along that beach in winter - from November to April.

Naturally, the work of the lookout was irksome and distasteful even to settlers inured to hardship. The perch on the spar was an uncomfortable seat in the best of weather, and a gale of wind searched the hut, in spite of the fire that was built, for every hut was open on the side toward the sea. However energetic these settlers 
might be in the actual work of killing a whale and preparing the products for market, some of them would shirk their tours of duty on lookout. Shirking roused the anger of those who did not shirk, and therefore, to preserve peace in the community, it was necessary to give some one authority "to call out ye town to loke for Whale."

To this delicate and thankless task "Goodman" John Mulford was called in $165 \mathrm{I}$. It may be noted also that he was chosen to serve as magistrate during the same year.

It has seemed important to give these facts about the whaler settlers of Long Island, partly to set forth something of the character of their work, but chiefly because "Goodman" John Mulford was the father of Samuel Mulford, who was not only the most notable whaler of his day, but a patriot of the colonial period, whose work has never received the attention it has merited.

Samuel was six years old when, in 1651 , his father was authorized to "call out ye town to loke for Whale." In connection with his career it will be interesting to consider a peculiar feature of the work of the whalers among whom he was 
6 The Story of the New England Whalers

raised. It was the custom to employ the natives of the island, the red Indians, in the boats used for pursuing the whales. The story of the Indian as a whaler shall be told in the next chapter, but it may be noted here that the tribesmen of various parts of the American coast had been in the habit of going afloat in canoes in pursuit of whales before the white man came, and that they succeeded, now and then, in worrying one to death, though possessed of no more efficient weapon than a bone spear or a flint-pointed arrow. And that is to say that they were able and courageous in the handling of such weapons as they had. How the European invaders usually treated the unfortunate aborigines is very well known to all readers; the story as a whole is shocking, but at the east end of Long Island the white settlers employed the Indians as whalers instead of exterminating them. Moreover, the pay given to the Indians when thus employed was three shillings a day at a time when that of common white laborers was two shillings.

In fact, the competition of individual white whalemen for the services of the more expert 
red men led, in time, to an increase of the pay given to a point where the white community as a whole deemed it necessary to enact a law for the regulation of the matter. The act declared that "whosoever shall hire an Indyan to go a-Whaling, shall not give him for his Hire above one Trucking Cloath Coat, for each Whale, hee and his Company shall Kill, or halfe the Blubber without the Whale Bone."

Samuel Mulford was not only trained by a father who was noted for his sense of justice, but he grew up in a community that would provide by law that Indians might receive a "lay" of half the blubber of the whales they helped the white men to take.

The details of the training of Samuel Mulford in the actual work of a whaler are not recorded, but it is not to be doubted that he learned to hurl the harpoon and use the lance as soon as he had the strength to do so, and that he became an expert in "saving" whales. Further than that, it is certain that he became a leader in the community, as his father, "Goodman" John, had been. As a whaler of skill and a foremost citizen 
8 The Story of the New England Whalers

of his community, he lived for about seventy years, and he would have died without any greater claim upon posterity than such a career afforded but for an arbitrary attack that was made, meantime, upon the rights of all American whalers of his day. When this attack was made, Samuel Mulford, animated by a hatred of injustice that was hereditary and ingrained, stepped forward alone as the champion of his guild, and won in a fight that, as said, has made his name memorable in the annals of the nation.

It was in the days when Governor Robert Hunter ruled New York. Hunter, in his early youth, was an apprentice to a druggist, but having entered the British army, he rose by good work and hard fighting to the rank of major general. Then, at a time when he was not needed in the field, he was sent to succeed Governor Lovelace in New York. The rise of the poor apprentice to such high rank shows that Hunter was a man of uncommon ability; and that is not all one may learn in his favor. His papers show that he wrote French at least as well as he did English. $\mathrm{He}$ had educated himself while working his way up 
in the army, and "his intimacy with Swift and Addison and the other wits of the day affords another proof of his literary taste."

Until he received his commission as governor, Hunter had grasped at power and position chiefly; in New York he reached out for wealth as well, and thus fell foul of the Long Island whalers. Observing that no tax was paid on the catch of whales within his colony, Hunter decreed that the whalemen should pay him one-twentieth of all the oil and bone they gathered, not only from drift whales, but from those captured with boats; and the share thus to be taken was to be delivered to him in New York, a point more than a hundred miles, on the average, from the whaling grounds. The whalers having ignored the decree, "there was a writ directed to the sheriff [I III] to seize all whale fish whatsoever" in order to compel the whalers to bring in the share of oil demanded.

Up to this time Long Island whaling, though it had been carried on by means of small boats only, had been fairly profitable. A report by Lord Cornbury, dated July I, I708, in speaking 
Io The Story of the New England Whalers

of this matter, says that "for example last year they made 4000 Barrils of Oyl." . On the other hand, in the season preceding this very profitable one, only six hundred barrels had been secured. It was plain to all the fishermen that if they were to be taxed one-twentieth of their gross product of oil every year, they would have their labor for their pains during a large part of the time. This fact was, naturally, quite enough to create opposition, but a loss of profits was not the only feature of the situation that aroused the indignation of the whalers. Fishing was among the rights that had been granted to them in the patent to their lands, and for that patent they paid a yearly tax of forty shillings. Under the rights thus granted them they had been accustomed, from the making of the settlement, a period of more than seventy years, "to go out upon the Seas, adjacent to their Lands, Six Men in a Small Boat, to take and kill Whales and other fish, and the Capters to have all they killed."

That a governor, sitting at ease in New York, should demand a share of their hard-earned produce from the high seas, after all those years 
of freedom from such a tax, was bad enough, particularly as the levy was made without any pretence of a return to them for what was thus to be taken; but fully to understand their indignation in the matter, it must be remembered that they had been, practically, republicans, making laws for themselves, at least in local matters, and paying very little in the way of taxes save as they made levies upon themselves for the benefit of the community.

After the sheriff came among them with his orders to "seize all whalefish whatsoever," some few of the whalemen paid the tax. Others, more indignant, ceased fishing for whales. Of neither of these classes, however, was Samuel Mulford. With his two sons, Timothy and Matthew, and enough Indians to complete the crew of the boat, he went to sea whenever the lookout reported a whale, and he disposed of the catch according to the ancient custom under which the "capters" had "all they killed."

In the days before Governor Hunter levied on the product of the whale fishery, Samuel Mulford had served his neighbors as a civil justice and as 
12 The Story of the New England Whalers

a lieutenant of militia. He was now chosen to represent the community in the General Assembly. It was hoped that he would there be able effectually to oppose the governor's schemes. Apparently Governor Hunter feared the influence of the whaler in the legislature, for he promptly got out an anchor to windward, so to speak, by creating new assembly districts in territory wherein he was able to control the elections, and he was thus able to secure a working majority.

Mulford was thus balked of his hopes of relief through legislation, but he took the legislator's privilege and freed his mind by a speech before the assembly, in which he not only set forth the rights of the whalers, but exposed a number of the other grasping schemes of the governor in merciless fashion. He who had hauled in alongside a whale was not to be frightened by any kind of a man, however great in power and station.

Of course the governor struck back. The obedient assembly expelled the bold whaler. Then a creature of the governor who held the office of Chief Justice of the Supreme Court, 
assisted by the prosecuting attorney, proceeded against Mulford for the "high misdemeanor" of uttering "a false and seditious libel," and that, too, in spite of the fact that under the law the speech was privileged. Still further to harass the whaler, "an action of trover" was commenced against him and his sons "for converting the Queen's goods to their own use."

As the action for libel could not be lawfully pressed, the charge was continued from term to term during four terms of the court; and at each term the old man was brought to town, a distance of one hundred and fifteen miles. He was tried on the charge of trover by the Chief Justice, although he appealed, as a matter of right, for a jury trial. Of course he was convicted. In short, every method known to an adroit politician in power was used to annoy and overpower the determined whaler, who, in spite of losses and personal persecutions, continued the fight.

A remarkable figure is Samuel Mulford as he is portrayed in the records of his day. Governor Hunter frequently speaks of him in letters sent to England as a "crazy old man." Gardiner's 
I4 The Story of the New England Whalers

East Hampton says he was "an original genius of good judgment but of an odd turn." It is related that while he was a member of the legislature he got into trouble by saying that the House was governed by the devil. When brought to the bar by the speaker, he explained that what he had intended to say was that the House was ruled by the Albany members, they by Colonel Schuyler, he by the Mohawk Indians, and they by the devil; whereat everybody laughed so heartily that the old man was forgiven for his plain speech. That he should have made such a decided stand against the governor was evidence in the minds of average citizens that he was what would now be called a "crank." But if his motives and ambitions be now examined, it is seen that he was not only the ablest citizen of Long Island, but a far-seeing statesman, one worthy of being ranked with the patriots of the Revolution. For he had come to be animated, not by a foolishly stubborn determination to oppose a tyrannical governor, but by a lofty spirit of patriotism. The fight as he made it was not to escape the payment of a fine of $£ 50$ that had been im- 
posed upon him, but to establish a principle, as shall now appear. Parliament had provided special encouragements for "subjects within this Kingdom," who might wish "to go a Whale Fishing to Greenland, Friezland and places adjacent." In Mulford's view "the subjects in New York" had the same rights under that act as any Englishman in England. If that were so, the decree of Hunter for taxing the fishery was contrary to the act of Parliament for encouraging it, and this was the plea which Mulford's attorney made when he was arraigned on the charge of trover. The subservient Chief Justice, in considering this plea, declared that the colonists "had nothing to do with the acts of Parliament," and that they "had no law but what the Crown allowed" them.

On hearing this decision Samuel Mulford determined to learn "whether the Subjects in New York Colony are to be governed by Prerogative and deprived of property, or whether they are to be governed by the Constitution of English Government." That is to say, Mulford made his fight to determine the rights of the colonists as British citizens, and not merely to escape a petty fine that he was well able to pay. 
I6 The Story of the New England Whalers

Finding the power of the governor too great for him in the colony (Hunter called him a traitor for standing out against the decision of the Supreme Court), Mulford left home secretly, crossed over to Newport, walked thence to Boston, and sailed for London to lay his case before the Crown.

Rarely has a man seen a greater change in his surroundings than Mulford saw when he went from the stern sheets of a Long Island whale boat to the crowded antechambers of those who waited upon royalty at the beginning of the eighteenth century. Dress, manner of speech, and every motion proclaimed him a wayfarer from a far country. The pickpockets of the streets "annoyed" him much. The gentlemen of the court found him vastly amusing at first, and latterly, as he persisted, perhaps something of a nuisance. But the resourcefulness and the determination of the whaler were in him. He sewed fish-hooks inside of his pockets, and so caught the light-fingered thieves; and by other hooks equally effective he drew those in authority around him until the Lords Justices wrote to Governor Hunter, saying plainly, "We must observe to you that we 
hope you will give all due encouragement" to the whalers.

Before Washington was born, Samuel Mulford, the alongshore whaler of Southampton, set the pace to which the patriot hosts at Lexington were to march. Decision on the main point for which Mulford contended was avoided. That was left for later arbitrament. But Hunter was compelled to reply, "I have remitted the five percent on Whale Fishing." By means of the mental qualities that he had cultivated when "out upon the seas" with "six men in a Small Boat to take and kill Whales," Mulford triumphed over one of the ablest of the royal governors of New York.

This account of Samuel Mulford has little of whaling in it, but it seems well worth telling here, first of all, because one of the most important features of the American whale fishery is found in its influence upon the men who were engaged in it, and, through them, upon the whole people. 


\section{TOLD OF THE RED INDIAN WHALERS}

$\mathrm{N}$ the early days of Nantucket, while yet the people were engaged in alongshore whaling by means of small boats only, it happened one day while thirty boats were in search of whales at a distance of something like six miles offshore that the wind suddenly whipped around to the north and began to blow with great violence. At the same time snow began to fall.

In the circumstances there was only one thing for the whalers to do, and that was to head for land and pull with all their might. This was done, though without much thought of danger at first. Boats were often caught thus by an offshore wind, but as time passed it became apparent to all hands that they were making little headway against the gale, and then one after another of the oarsmen became weary, and finally discouraged. Through the weakness of these men 
the headway that had been made theretofore was soon lost, and a time came when the whole flotilla was at the point of drifting away to sea.

But at that moment, when thirty boat loads of men were held in a balance that was wavering to and fro between life and death, one of the Indians employed shouted in a loud voice:

"Pull ahead with courage; do not be disheartened; there are too many Englishmen to be lost now!"

It was a voice like that of old Cornstalk, as he raged to and fro at the battle of Point Pleasant, shouting to his men: "Be strong! Be strong!" It was even more than that, for the words were a keen taunt to the white men who had shown discouragement. And when those words were heard, the weak, as well as the strong, bent to their oars once more, and with an increase of energy that carried the flotilla to safety.

The historians who have from time to time considered the whale fishery have all been much interested in a discussion concerning the first whalers known to the record. It is pretty well agreed among them that the peculiar people 
found in certain places along the north coast of Spain, and called Basques, were the first to make whaling a regular business. The ancient documents to be seen there show, at any rate, that in I150 King Sancho the Wise granted special privileges in the matter of whaling to the city of San Sebastian; and there is no record about whaling to be found elsewhere among civilized people of earlier date. It is not to be inferred from this fact, however, that the Basques were the inventors of the arts of whaling. The aborigines of Europe in the stone age were certainly as courageous and venturesome as those of America, and the first white men to explore the coast of New England found red whalers at work. In every clan and tribe along the coast were men accustomed to killing whales.

Most interesting to the humanitarian is every record of things done by the red men of America in the days when they were undefiled by contact with the white race. And of the stories of the things done, few if any portray red manhood in brighter colors than those relating to the whale fishery. 
One can appreciate the work of the red whalers, however, only after a consideration of some details of his weapons. On the Atlantic coast the Indians had stone-headed arrows and stoneheaded spears. The arrow-heads were about two inches long; the spear-heads four or five. Some were made longer than the dimensions here given, but the average weapon of each kind was no larger. These weapons were used on land for killing deer and other animals found in the forest. For the land animals they were efficient enough. Deer, moose, elk, and bears were all killed with such weapons easily, though always at such short range that the Indian was almost within touch of his prey. The white man, with his repeating rifle that fires a bullet through a quarter of an inch of iron plate, may well wonder at the ability of the Indian to strike down the moose with stone-headed arrows.

To secure the whale, the Indian had to go afloat upon the sea, and it was during the winter season that whales were found in greatest numbers along the Atlantic coast. In modern days we praise the courage of our life savers who go 
22 The Story of the New England Whalers

off to stranded ships in twenty-eight-foot surf boats, built with all the strength that modern skill and the best of tools can give them; and provided, moreover, with air-tight tanks at each end that will keep them afloat even when a hole in the bottom lets the water in. The life savers deserve all the credit they get, and more too; but the Indian, let it be remembered, went afloat on the ocean in a canoe, the frame of which was tied together with sinew, the planking composed of the bark of a tree, and the cracks calked with the fat of animals mixed with spruce gum.

Two kinds of whales were commonly hunted by the Indians. One was the black fish that came in large schools to such sheltered waters as were to be found under the point of Cape Cod and elsewhere along shore. To kill these was not a difficult matter. The other kind was the right whale. In two respects, at least, the right whales were of a character to try the nerves of white men as well as of red. Thus, as they swam to and fro, with their lips up, sucking in the food that floated upon the surface of the sea, the spectacle was so horrifying that the officers in the 
whale fishery of the white men were careful never to allow a "greenhorn" to look at it lest he be frightened out of his senses, and even men of experience sometimes feit their nerves quiver as they gazed upon one of these whales that was approaching the boat. To the superstitious Indians, therefore, the right whale must have seemed to be the embodiment of the most frightful spirit of evil. Nor was it the appearance of the beast alone that impressed them thus, for this whale, when angered, was a monster of devilish power and instincts. To enormous strength it added astonishing agility. Raising its widespread flukes in air, it would sweep them from jaw to jaw, searching, sometimes swiftly and sometimes with a gentle touch, here and there for traces of its enemies. Everything within the sweep, whether boat or man or splinter, was instantly detected and crushed under a blow from that tail.

And yet the Indians, with their frail canoes and their stone-headed spears, swarmed out to sea in pursuit of right whales whenever they saw the spouts, unless, indeed, the surf was impassable. 
24 The Story of the New England Whalers

Puny were the implements of the red whalers, but what they lacked in implements they made up with courage, ingenuity, and perseverance.

In John R. Jewett's Narrative of his adventures among the Indians of the Northwest coast, it is said that the Indians used harpoons made of wood shafts with pieces of shell for points. It is remarkable that these Indians, who made enormous and seaworthy canoes from the trunks of huge trees, should have used such frail weapons as the shell-pointed spears were; for they met, now and then, the Eskimos living farther north, who had harpoons and spears of superior construction. Jewett won the regard of his Indian masters by making whaling implements of iron; but he says in his Narrative that his work only made them the more determined to keep him from returning to civilized parts of the world.

The weapons made by the Eskimo whalers were the best of any ever found among the aborigines of America. The ingenuity displayed by them in making what is known among white whalers as the "toggle" harpoon was remarkable. Taking a walrus tooth the Eskimo mechanic 
carefully scraped one end to a point, and then, after cutting a slit in the point, he inserted a triangle of chipped flint or of some other kind of stone ground to a point and a cutting edge. Just why a stone point was added to the ivory point has never been explained. Then midway of its length he bored a hole crosswise through the tooth, and through this hole he secured what the white men called the warp or harpoon line. Above this hole another one was drilled lengthwise of the tooth, and this was shaped so that it served as a socket for the insertion of the handle of the harpoon. The part of the tooth above this hole was then carved into the shape of a barb, and some of the more artistic harpoon makers shaped the barb so that it looked like the upturned tail of a fish. To complete the weapon an inflated sealskin float was attached to the loose end of the harpoon line.

When the Eskimo hunter arrived alongside a whale, he jabbed his harpoon into the animal until the walrus-tooth head was buried out of sight in the blubber. Then he jerked away the harpoon handle, leaving the head of the harpoon 
26 The Story of the New England Whalers in the whale, and threw overboard the sealskin float. The whale, in plunging under water, brought a strain on the harpoon line, of course, because of the resistance offered by the float; but this strain, instead of drawing the harpoon head out of the whale, turned it around in the blubber so that the only way of getting it out thereafter was to cut it out.

This "toggle" harpoon was in use above Bering's Strait and on the coast of Greenland for no one knows how many years before a bright Negro blacksmith at New Bedford invented the same style of weapon for the use of white whalers.

As for the Eskimo lance, it consisted of a long shaft with a chipped-flint head as broad as a man's hand - a genuine paleolith sort of spear, such as the ablest of the cave dwellers would have thought perfection. It seems to the white whaler now like a crude weapon, something "heathenish for fair," as the writer once heard an old whaler say; but while the modern Eskimo has the lighter and sharper lance of the white man, together with the terrible bomb-lance gun, he yet carries one of those ancient stone-headed 
weapons. With the skill and strength of his ancestors he drives it home as soon as possible after he has struck his whale with the harpoon, and it is only when this has been done that he turns to use the steel lance and the bomb gun which he buys of the white man.

The float was the distinctive feature of the Indian whaler implements. White and red whalers alike used barbed spears for harpoons, but it was the red man who always used the float in connection with the harpoon. On the Atlantic coast the Indians made their floats of logs of light wood which were of as large a size as possible without bringing a strain upon the harpoon line that would pull the head from the wound or break the line. The line was only a few feet long. To have made it longer would havc allowed the float to come within reach of the flexible tail of the animal. The Indians depended upon these floats to impede the progress of the whale as it strove to escape from them. A single float, whether it were an inflated sealskin or a $\log$ of wood four feet long, did not materially lessen the speed of a fleeing whale; but when the Indians 
28 The Story of the New England Whalers

went hunting these animals they gathered around their victim in numbers, and thrust in so many of their harpoons that only the stronger of the whales were able to escape from them. Many an Indian canoe was smashed by the fighting whales, and many an Indian thus lost his life; but with the red as with the white whalers the dangers did but add to the joys of the chase.

The white settlers on the Atlantic coast promptly made friends with the red whalers. This is not to say that the white whalers always gave the Indians fair treatment; but, as already noted, the red men were employed, not exterminated with swords and guns, nor even driven away. It is not unlikely that the first whale boat that was set afloat by the white settlers was manned in part by Indians, and in all times until the present day red men and white have been found pulling together to the tune of "a dead whale or a stove boat." The records say that they have always been good oarsmen and the very best of harpoon throwers. More than one American whale ship has had red men for mates, but no record of one serving as a captain is known to the writer. 
While the Eskimos have always been on friendly terms with the white whalers (too friendly for their own good), they have never been employed to any considerable extent in the crews of the Arctic whale ships. Their principal connection with these whalers has been in the exchanging of whalebone for the weapons used by white men, and for other less useful products of civilized countries.

The work of the modern Eskimo whaler, as described by John Murdock, a scientist in government employ who spent a winter at Point Barrow to study their habits, is extremely interesting. The whales in working their way to the breeding grounds at the north of the continent pass Point Barrow in the months of May and June. Accordingly, the Eskimos begin their preparations for whaling in April. First of all the umiaks (whale boats), which are stored away during the winter, are brought out. The frames are carefully cleaned, the lashings are all renewed, and the skins that cover the frames are soaked, repaired, and stretched into place. The weapons of all kinds are also carefully cleaned. This 
30 The Story of the New England Whalers

work is not done because the Eskimo dislikes dirt to any extent, but because his religion or his ideas about luck make him think the things should be cleaned. In this particular respect the Eskimo differs, by the way, from the white whalers, many of whom think that cleaning away the dirt that accumulates on the masts of a ship while cutting in blubber would surely bring bad luck.

When the owners of the umiaks have their cleaning done, they hire their crews. For it is to be noted that the modern Eskimo is a capitalist - an employer of labor. Some of them own property of considerable value by the white man's standard. That is to say, some of them own harpoons, lances, and bomb guns to the value of several hundred dollars, as well as boats. In hiring his crew the boat owner sometimes pays stated wages in tobacco, knives, guns, cartridges, etc., which he obtains by selling bone to white traders. Usually, however, he follows the white custom and gives each man a "lay" or share of the whalebone taken, the bone being the merchantable portion of the whale. 
Having selected his crew, the Eskimo owner looks after the charms and amulets which he and his men are to carry afloat to insure success. The skin of a raven, the skull of a wolf, and the incisor teeth of a mountain sheep are all valued for the luck they are supposed to bring to whalers. So, too, is a stone image of a whale; but nothing else is prized quite as highly for this purpose as a bunch of feathers from a golden eagle, or a few hairs from the tip end of the tail of a red fox.

When open water is seen offshore, the umiak is loaded on one sled and the gear upon another. Dogs drag the sleds across the ice to the water, and the women go along to guide it and push. Having launched their boats the crews go cruising, and as it is by that time perpetual day, they remain afloat as long as they can endure the work, eating and sleeping as they can. The women bring food to the edge of the open water from' time to time.

The attack upon the whale is made by a rush of all the boats, as was that of the Indians of Long Island, though the Eskimo must now be much more cautious than in other days, because 


\section{The Story of the New England Whalers}

whales have learned to fear the whaler. The modern Eskimo is, if possible, more reckless than any red whaler of former years. Because of the ever present ice under which the whale usually tries to escape, he must strike while he may, and to see an Eskimo taking chances in order to get a thrust with his lance or a shot with his bomb gun is the experience of a lifetime; for the Eskimo whaler is always so anxious lest his prey escape that he never gives any thought to the dangers he may be risking.

It was the custom of the red whalers to divide the meat and blubber which they took among their neighbors - among the whole community, that is. This custom still prevails among the Eskimo. They are so far socialists. The bone was also common property in former days, but now it is divided as prize money is divided among the crews of war-ships, all boats within reach at the killing, and no others, share the bone. Bone is held as private property now because the white trader will buy it. With bone held as private property the Eskimo whaler of unusual ability now has what a white man would call a tangible 
profit from his work in proportion to his skill. Yet it appears that the able Eskimo of other days was not without a somewhat satisfactory reward; for while bone as well as meat was shared among all, he was distinguished as the leader of his community. The white whalers say that the Eskimo has made progress in civilization through acquiring civilized ideas about personal property. The fact is, however, that his habit of thought has been changed only in the increase of selfishness, and as for the reward for his superior skill, it appears that, if he should come to own a dozen. bomb guns instead of one or two, and many boats loaded with other gear, he could never be, at best, more than the leader and benefactor of his community, while at the worst he might enslave all his neighbors.

Since the whale has been in all times a principal source of food and other supplies, the red novelists - the myth makers - have naturally directed much attention to it. It is a pity that the traders who have bought the bone of the red whalers have always considered the red man's literature, if that word may be allowed, as the mere gibberish 
34 The Story of the New England Whalers

of idolaters. If we could have had a Ruskin to place their myths before us, we should have found in them something more than idle talk; for, however told, the stories of the red men give us an insight into the life of the igloo and the tepee not to be obtained in any other way.

As a final view of the Eskimo whalers, consider their "Myth of the Raven, the Whale, and the Mink," as gathered by Nelson near Bering's Strait and printed in the Eighteenth Annual Report of the Bureau of Ethnology:

Seeing a Whale near the shore the Raven shouted:

"When you come up again shut your eyes and open wide your mouth." The Whale did as he was ordered, and the Raven, "carrying his fire drill under his wings," flew "straight down the Whale's throat." As the whale plunged under water once more the Raven found itself "at the entrance of a fine room, at one end of which burned a lamp," and he "was surprised to see a very beautiful young woman sitting there," the young woman being "the shade or inua of the whale which was a female."

The young woman made the Raven welcome and went about preparing him a meal of berries and oil. Every time she went out of the room while thus engaged, 
she called his attention to a tube leading along the top of the room from the end of which oil was dripping into the burning lamp. That tube, she said, he must not touch. In spite of the repeated warnings, however, his curiosity led the Raven to catch a drop of the dripping oil on one claw and lick it off with his tongue. The taste was so sweet that he caught more of it, until finally that method of collecting the oil "became too slow for him, so he reached up and tore a piece from the side of the tube and ate it." Instantly "a great rush of oil poured into the room extinguishing the light. ... The inua never came back to the room and the whale drifted ashore."

The Eskimos of a near-by village found the dead whale, and in cutting it up released the Raven. Leaving his fire drill behind him, the Raven flew away unobserved and alighted upon a hill from which he watched the people at their work. After a time he changed himself into the semblance of a man, and joined them in cutting up the whale until he found his fire drill. With that in hand he began rolling down his sleeves, saying, "This is too bad, for my daughter has told me that if a fire drill is found in a whale and people try to cut up that whale, many of them will die. I shall run away." "And away he ran," adds the tale.

Being frightened, the people ran away as he had done, whereat the Raven laughed heartily, and return- 


\section{The Story of the New England Whalers}

ing to the whale began to cut it up for his sole use. Later, upon observing that he had nothing in which he could store the oil, he called on the Mink for help. The Mink invited the "sea people," the seals, to a feast in a house that he and the Raven built. When the sea people came, and had filled the house, the Raven said to them:

"What a number of people! How shall I be able to make a feast for all of you? But never mind; let me first rub the eyes of some of you with this stuff in order that you may be able to see better; it is dark in here."

"This stuff" was a ball of gum that closed the eyes of the seals, effectually blinding them, whereupon the Raven killed all but one, that, through an oversight, escaped to the sea.

"When he had finished Raven turned to Mink and said, 'See what a lot of seals I have killed. We will have plenty of oil bags now.' Then they made bags of the sealskins and filled them with oil for the winter. Ever since that time Raven and Mink have been friends, and even to this day ravens will not eat the flesh of a mink, be they ever so hungry; and the raven and the mink are often found very close together on the tundras."

These sauvage whalers were a rude people, but they could look into a whale and see its inua in 
the form of a beautiful young woman sitting beside a lamp that burned as long as the whale lived. They saw the cunning of the raven, the simplicity of the seal, and they laughed heartily at the thought of a raven taking a whale from them by guile. They could while away the long hours of a winter's storm by elaborating a story to explain a strange companionship that they had observed among the tundras.

Not less interesting were the mental characteristics of the whalers found on the other coasts of America. If we could but see their courage and fortitude, and their humor and poetry, they might seem now to be something different from the vile and degraded heathen they were supposed to be when the white men first came among them. 


\section{III}

\section{EARLY DAYS ON NANTUCKET}

A CCORDING to a story told by the myth makers among the red whalers, a mighty giant who, once upon a time, lived on the Atlantic coast was in the habit of using Cape Cod as a sleeping place - partly because the warm and yielding sands were comforting, and partly because the shape of it fitted him well when he curled down to rest. One night, however, he was so restless that he kicked his feet around the whole night long. Naturally the cape sand was scooped out and bulged up, here and there, forming hollows and dunes to be seen to this day, and what is of more interest here, the giant got his moccasins well filled with sand. When awakened the next morning he found the sand in the moccasins particularly annoying because of the ill humor following such a night, and taking off first one moccasin and then the 
other, he flung their contents away across the sea, and thus made Martha's Vineyard and Nantucket and the shoals beyond.

Whether this myth is regarded as the absurd emanation of an idolatrous brain, or the vision of a poet who saw dimly the workings of the giant forces of nature, it gives the account of the origin of Nantucket as it was told to the first white men who settled on the island.

Of the settlers themselves we have a more detailed record. One Thomas Macy, living in Salisbury, in the colony of Massachusetts, gave shelter and food to three or four Quakers who were fleeing through a storm from the persecutions of the Puritans. In due time the officers of the colony came and demanded the Quakers; but Macy, who had been in the army under Oliver Cromwell, refused to give them up, until the Quakers saw that their host in defending them was preparing serious trouble for himself and insisted on surrendering themselves. Thereupon the officers took them away and hanged one of them. Then, being as yet unsatisfied, they returned to persecute Macy, and in this they persisted until 
40 The Story of the New England Whalers

he was obliged to fly. Embarking his family in an open boat, with a friend named Edward Starbuck, Macy sailed across Massachusetts Bay, rounded Cape Cod, and, braving the perils of the open sea, crossed to Nantucket Island. There, "as the Indians were not sufficiently enlightened to abhor his crime, the dispenser of unlawful hospitality was kindly received and permitted to live in peace."

The first white explorer to see Nantucket was Bartholomew Gosnold, who went cruising among the islands south of Cape Cod in 1602 . The title which his discovery gave to the British was found in the hands of the Earl of Stirling in I64I. The earl's American agent sold the island on October 13 of that year to Thomas Mayhew, a merchant of Watertown, Massachusetts, for $£_{40}$. Mayhew still owned the island when, in $165^{8}$ or I659, Thomas Macy fled from Salisbury; but no one had been able, up to that time, to secure a foothold among the red inhabitants - a fact that gives interest to the story of Macy's choice of a location and his success in obtaining a welcome.

Finding the island very much to his liking, 
Macy remembered some of his friends in his former home - men who were lawless enough to give shelter to Quakers adrift in a storm - and sent Starbuck back to tell them what was to be found on Nantucket. This mission was so well executed that several families agreed to emigrate. The whole company thus formed united to purchase the island from Mayhew, who, after reserving one-tenth of it for himself, sold the remainder to Tristam Coffin, Thomas Macy, Christopher Hussey, Richard Swayne, Thomas Barnard, Peter Coffin, Stephen Greenleaf, John Swayne, and William Pike. Mayhew and the nine men here mentioned are known in Nantucket annals as "The Ten First Purchasers." Each of the ten afterward took a partner on equal terms and thus the "Twenty Purchasers" were organized. To omit mentioning the "Ten First Purchasers" and the "Twenty Purchasers" in any account of Nantucket would be, in the eyes of Nantucket people, like a history of the United States with no mention of the Declaration of Independence.

On emigrating to Nantucket, the "Twenty Purchasers" bought "the right of the Indian 
42 The Story of the New England Whalers

Sachims the tenth of May, I66o." As the record very clearly shows, not one of the Nantucket settlers was a whaler. All were frontier home makers-such men as those who crossed the Alleghanies a hundred years later to create the civilization that now distinguishes the Ohio Valley. Neither were they sailors, for the records show that they offered special inducements to one "William North, Salier," to come to the island and there "imploy himself or Bee Imployed on the sea ... and not to leave the island for three yeares time."

These settlers must have seen the red whalers at work, but it had no particular influence upon them, for it was not until a whale placed itself in a natural trap within their reach that they made any effort to go whaling. According to the tradition a "scragg" whale (a right whale having a number of small humps on its back) came into the harbor and remained there three days. Its prolonged stay "excited the curiosity of the people," according to Macy, the island's chief historian, "and led them to devise measures to prevent its return" to the open sea. "They 
accordingly invented and caused to be wrought for them a harpoon with which they attacked and killed the whale."

But if the settlers of Nantucket were not whalemen, nor even sailors, they had a love for the sea which was manifested in their custom of going to the hilltops to look over the waters surrounding their home. Indeed, they built platforms on top of their houses that they might have lookout perches more convenient than the hills. And according to a tradition of the island the habit of going to the hilltops to look at the sea eventually turned the thoughts of the people toward the whale fishery. As a number of the people were on Folly House Hill one day, so the story runs, one man pointed to a school of whales seen offshore and exclaimed:

"There is a pasture where our children's grandchildren will go for bread."

Of course it was an idle remark, worded in a manner peculiar to the day, but it was remembered for the reason that within the year when the remark was made (1690, according to Starbuck), the people of the island began to go regularly to that offshore "pasture" for "bread." 
44 The Story of the New England Whalers

The Nantucket method of undertaking the whaling business was characteristic and memorable. They sent in 1690 to Cape Cod, where, as they knew, "the people had made greater proficiency in the art of whale catching than themselves," and hired Ichabod Paddock, an expert, to come to the island and teach them how to do the work.

Comparisons may be odious, but they are none the less instructive. In the period when the Nantucket people sent to Cape Cod for a teacher of the arts of whaling, the French Canadians were also thinking about engaging in the same enterprise. As early as 1636 (Thwaites's Fesuit Relations, IX, I69), the Basque whalers worked in the St. Lawrence River "up as far as Tadousac, or farther," and schools of whales were seen at "Kebec." But when seeing these whales finally turned the thoughts of the French Canadians to the whale fishery, they did not hire a Basque to teach them the arts; they applied to their king for a subsidy with which to hire Basque whalers to do the work for them. The king gave them the "encouragement" they said they needed to estab- 
lish the industry. Some Basques were brought over to go whaling. Some individual French Canadians thus made some money. But when the king ceased giving the encouragement, the fishery ended. The difference between the French Canadians, with their subsidy, and the Nantucket people, with their schoolmaster, seems particularly well worth the attention of the patriotic Americans who are now interested in seafaring matters.

Under the lead of Ichabod Paddock the south shore of the island (more whales were seen off the south than the north shore) was divided into four beats, or districts, each about three and a half miles long. To each beat six men were assigned. A hut was built at the centre of each district for the shelter of the crew during stormy weather, and a tall spar with a "crow's nest," or lookout perch, at the top was erected on a sand dune near each hut to give a wide range to the eyes of a man who was kept on the perch at all times during the day, and possibly during moonlit nights.

These crews "carried on their business in common." They united their labor and means to 
46 The Story of the New England Whalers

build the huts, erect the spars, build the boats, and buy the necessary gear. When one crew went in chase of a whale, the others, summoned by a signal, joined as soon as possible. When a whale was killed the crews united to save the oil at try works erected near the beach for the purpose, and all shared alike in the product.

The work of getting the blubber into the pot was particularly laborious. The huge carcass had to be towed to the surf, and these men knew whether it was easier to tow it head first or tail first. At the beach the blubber was dragged from the carcass by means of a sort of capstan called a crab, after which it was cut into chunks that could be lifted into a cart.

As these men labored on the beach they were wet with the spray and with the sweat of their toil; they were chilled by the north wind's blast; they were smeared over with the grease of the blubber, and they were stung by the flying sand that the wind carried; but they kept the pot boiling.

As on Long Island, the Indians were employed. They soon learned to use the white man's weapons, and because they accepted as pay the unmarket- 
able parts of the whale, with clothing and other things manufactured by the whites, they were exceedingly profitable hands. The Nantucket solution of the race problem is memorable in connection with modern race problems.

The success of this first whale fishery is manifest from the fact that it not only persisted, but it grew. From keeping men perched on top of tall spars, "in order to observe the spouting of whales," the Nantucket men began to go afloat in their open boats. They went cruising offshore and thus at once increased their opportunities and acquired a skill and a venturesome habit of thought, which were of the utmost importance. The records show the results of their enterprise. In 1726 twenty-eight boats saved eighty-six whales. Captain Abishai Folger is credited with six, while Captain James Johnson and Captain Shubael Folger killed five each. The savings of the others numbered from four down to one.

It was in the stories of the offshore cruising that the account of the red whaler hero, as told in the last chapter, was found, and it was there, too, that the adventure of the first white whaler 
48 The Story of the New England Whalers

hero of the island is described. Captain Christopher Hussey, probably a son of one of the "Twenty Purchasers," while in command of an open boat, in 1712, was blown away to sea. That all hands labored with all their might to reach land is not to be doubted, but a time came when they could do no more.

As they were drifting away through the deadly perils of a winter's storm on the open sea, however, a school of sperm whales suddenly appeared. These Nantucket men had seen one whale of that kind. It had drifted ashore, dead, and they had probably shared in the product. A sperm whale was to them like a "pay streak" to a Rocky Mountain prospector, for "sperm," taken from a cavity in the head, was "thought to be of great value for medicinal purposes, . . . a certain cure for all diseases, . . . esteemed to be worth its weight in silver," or eight shillings an ounce.

And there within reach of the drifting Hussey and his crew was a school of sperm whales. Forgotten was the danger! Though the devil himself were knocking the spume from the wave crests, Hussey would go in chase of such a prize, 
and his men would bend to their oars at the word.

Thereupon safety was found in aggressive courage. Having killed the whale, the "slick" (the oil that oozed from the carcass) smoothed the sea so that they rode out the gale in safety. Then they towed their prize to the beach - the first of the kind ever killed by Nantucket whalers.

Most interesting is a picture of Nantucket life at that time. Every family had a home, - a log house with a thatched roof, or at best a roof of shingles that were held in place with long poles. They all owned sheep, cattle, and hogs that ranged the common pastures, and they cut their fuel in the common forest; but they raised their corn and wheat on lands which each owned individually. In connection with the fuel it was noted in the annals that the poorest among them warmed himself at a better fire than the lords of England could afford. And that they should have drawn such a comparison is a memorable fact because it shows that Young America was looking up.

Their farms not only afforded food, but cloth$\mathbf{E}$ 
$5^{\circ}$ The Story of the New England Whalers

ing. The women spun the wool of the sheep into yarn that was woven as well as knitted, and some of the skins of domestic animals were used for clothing.

It is noted in connection with the farm work that loans of seed and animals were easily obtained by all who needed such an accommodation because such loans were held to be "debts of honor." While all were farmers, none lived isolated. The homes were in the village that was then called Sherbourne. ${ }^{1}$ The houses were built close together, too. While the man was away from home it was a comfort to the wife to live with her neighbors close at hand.

Because they lived simply the men found that they needed to give only a few days to their farms to produce the necessities of life, and thus they were free to give many days to the profitable openboat whaling.

In the meantime the original plan of holding all things in common in the whale fishery had failed

${ }^{1}$ In the earliest days the village stood some distance west of its present location. It was moved because the people needed the better harbor facility found at the present site. 
to give universal satisfaction. Some who were stronger and more skilful than others thought themselves entitled to shares that should be in proportion to the work they did; and, being stronger and more skilful, they took the larger shares to which they thought themselves entitled, and the original associations of all on equal terms developed into a system of partnerships.

The socialistic community had separated into groups of partners in Hussey's time (I7I2). Working as partners the men of Nantucket cut trees in the forest, whip-sawed the logs into lumber, and with the lumber built boats. Iron (Spain made the best in the world then) was secured in exchange for oil, and the blacksmith forged the iron into nails for the boats, and into harpoons and lances. The lines or warps were also purchased with oil.

In the meantime some Nantucket men had invested in sloops fit for use on the open sea, fit, that is, when manned by such sailors as Nantucket now boasted. The first vessel larger than a rowboat owned on the island was the sloop Mary, of twenty-five tons, built in Boston in 1694 
52 The Story of the New England Whalers

and sold to Richard Gardner and his partners of Nantucket four years later. When Hussey brought his sperm whale to the try pot, five sloops of from fifteen to forty tons each were owned on the island, and with visions of the product of the sperm whale that was "esteemed to be worth its weight in silver," the people of the island began to fit out their sloops for whaling cruises of from five to seven weeks' duration; for the sperm whale was to be found only in deep water. Of course the vision of "sperma Cœti," salable at eight shillings an ounce, proved to be a mirage; but beyond the mirage was a solid substance of fine oil and candles worth good money.

Cash capital was lacking on Nantucket, and throughout New England, for that matter; but these men who had wrung the necessities of life from the sterile land were able, through a union of labor, and in spite of a lack of currency, to embark in a business that not only sent open boats rowing alongshore, but fitted out vessels able to keep the sea for two months at a stretch.

Out of the partnership system of fitting out whale ships grew the later "lay" system of paying 
the crew. At first, as noted, the owners were the crews, save only as the Indians were hired. When some had accumulated capital, they hired white men as well as Indians. But instead of paying monthly wages, as was done on vessels in the cargocarrying trade, the owners took the sailors into a form of partnership by assigning to each a share of the expected catch, this share being called a "lay." The lay was large or small, according to the skill and strength of each man employed.

The "lay" system of paying will be described more particularly in another place; but it is to be noted here that even after common ownership of boats and gear had been replaced by private ownership, men who had not invested a penny or a day's labor in either boat or ship or gear were yet made partners in the cruise for whales; they received a share of the catch in proportion to their skill and efficiency. Even the apprentice who helped the cook prepare the meals had his "lay." Where European whalers of those days sharpened the eyes of the men on lookout by an application of the "cat," every member of the Nantucket crew felt the dignity and responsibility of an owner. 


\section{The Story of the New England Whalers}

Consider, too, how the partnership plan of fitting out the whalers affected the whole industry. The coopers made casks in which the blubber was stowed until it could be brought back to the try pots that were yet located on shore. The boatbuilders, blacksmiths, and coopers - every one that furnished anything to the whaling outfit became an owner or stockholder in the new enterprise, and received a share of the proceeds in proportion to what he had supplied. In like manner the men who tried out the oil were shareholders. It was therefore inevitable that each man should do his work as well as he could; he was working for himself.

The frontier home makers who subdued the wilds of the nation have been justly lauded for their enterprise, courage, and fortitude. The men of Nantucket not only did all that was done by home makers elsewhere, but while they subdued the land they also accumulated capital for and established a new industry which prospered in a way that yet excites astonishment.

It was in 1690 that the islanders hired Ichabod Paddock to teach them the arts of the whaler. 
Four years later they bought their first sloop. In I7I2, the year that Hussey killed his first sperm whale, five sloops were owned on the island. Two years later the number was increased to nine, of which six were in the deep-water whale fishery. These sloops, in 1715, secured 600 barrels of oil and II,000 pounds of bone, which were sold for $£$ IIoo. In I730 Nantucket had twenty-five whalers in commission and they brought home oil and bone that sold for $£_{3200}$.

In the meantime the alongshore or open-boat fishery had been growing; it was in 1726 that the eighty-six whales already mentioned were taken.

A glance at the shipping in the coastwise and over-sea trade of the colonies, in the early days, will give one a better idea of the conditions under which the whalers made progress. Ships were built and fitted out at various points on the coast by men who had little or no cash capital, but an abundance of strength and enterprise. They began with fishing smacks of the smallest size, and the codfish they obtained with the smacks, when exported, brought the iron, sails, ropes, etc., 
$5^{6}$ The Story of the New England Whalers

needed in building larger vessels. Timber products were important items in the exports, and, in time, finished ships. So the colonists became ship owners and merchants trading to many foreign parts.

The profits on the early voyages varied greatly. Weeden notes that a cargo brought from Bermuda, in 1636 , by Thomas Mayhew, returned a profit of "twenty od pounds." John Winter of Richmond Island, Maine, in 1639 , sent pipe staves costing $£ 6 \mathrm{I} 4 s$. $3 \frac{1}{2} d$. to England, and realized $£ 26 \mathrm{I} 7 \mathrm{~s}$. on the venture. A schooner that went to Nova Scotia to trade for furs secured a cargo valued at $£$ Iooo. John Hull, a notable merchant of Massachusetts, wrote that the profit in the passage of a ship from London "may be neer $£ 100 . "$

The slave trade was often particularly profitable. In 1696, for instance, the brigantine Seaflower brought forty-seven negroes from Africa to Rhode Island, which sold for from $£_{30}$ to $£ 35$ each. In 1727 a prime slave, fresh from Africa, would bring as high as $£ 80$ at Salem. Of course the cost of slaves on the African coast varied. A few gallons of rum or "ten shillings in English goods" often 
sufficed. At other times the trader had to give goods costing as much as $£ 12$. The margin at worst was large. Then because the negroes were generally sold in the West Indies, and a cargo was brought thence to the home port, another profit was secured.

Rum was the best cargo taken to the black coasts for trade, and it is an interesting fact that while the Nantucket people were developing the whale fishery, their neighbors in Rhode Island were developing especial skill as distillers of molasses. Rhode Islanders were noted for their ability to make a gallon of rum from a gallon of molasses, and in consequence of their superior distilling they soon had a long lead in the slave trade. As is pointed out in The American Slave Trade, "Rhode Island had 150 vessels in the African slave trade in $1770 . "$

In the cod fishery of the 'seventeenth century the ship owners took half the catch, the crew dividing the other half. Later the owner had to be content with only a fifth, if he were to get a crew for his ship, and thereafter the thrifty crews had opportunity to become owners. 
58 The Story of the New England Whalers

In the coasting and the over-sea voyages of the freighters it was customary to allow captains and mates to carry "private ventures." Each with his own money bought such goods as he supposed would sell in the ports to which the ship was bound. These goods were (in limited quantities, of course) carried free of charge. The proceeds were invested in foreign goods for the home market. A few voyages were made in which the crew received no wages; the profit on the private ventures which all carried sufficed. The slaver captain, in addition to his wages, had a commission of five per cent on the sale of the negroes in the West Indies, and five per cent more on the purchase of a cargo there for the home market. Furthermore he was allowed the price of four out of every one hundred and four slaves delivered in good order, and was permitted to buy five more with his own money and carry them freight free. The mates were allowed to carry two negroes each, bought with their own money, free. In short, in all the colonial ships of early days all of the officers, and at times the men, had some opportunity for profit beyond the wages paid. Thrift 
and enterprise were encouraged, with the result that American shipping increased at a marvellous pace.

Most interesting is a comparison of the opportunities of the men in the various kinds of ships during the early (eighteenth century) days of the colonies. The average captain of the average slaver certainly made much more money than the average whaler captain. Even when the owners of cod-fishing vessels took one-half the catch, the crews received a greater per cent on the sale of the fare than the crews of whalers secured from their lays. If the fact that a slave ship was a floating cesspool kept Nantucket men from the slave trade, there was no such objection to the cod fishery. Even the cargo-carrying trade afforded, on the average, more money to the crews than the whale fishery. Hull paid his captains $£_{4}$ a month and his best seamen $£ 2$ IOs. The average whaler did not get as much as that. Thus in 1730 the twenty-five vessels that brought in $£ 3200$ worth of product had only $£ \mathrm{I} 28$ each. The captains with a lay of one-eighteenth received for that year less on the average than $£ 8$, where one of Hull's captains earned $£ 48$. 
6o The Story of the New England Whalers

How did it happen, then, that anybody went in search of whales? Why did not all Nantucket men forsake whaling for the cod fishery or cargo carrying? For one thing, habit held them from it. The men of Massachusetts Bay, living within easy reach of populous fishing banks, had developed the cod-fishing habit; the Nantucket men, living near the whale-feeding grounds, had developed the whaling habit. Further than that, the income of the whaler was not as bad as the figures make it seem, for there is no statement of the length of time passed at sea in securing the $£ 3200$ worth of oil and bone. At most the captain was afloat for three or four cruises in the course of a year, and a cruise lasted for six or eight weeks. The Nantucket men were yet farmers as well as whalers; they spent much time caring for land and flocks. The average yearly whaling income of a captain was usually earned within six months, at most, passed at sea.

Of course, even with these facts in view, the whaling income on the average was so far below that of the other seafaring men that one must look still farther to understand the matter. Any 
inference drawn from a statement of the average income of the whalers is sure to be misleading in a consideration of the influence of the fishery upon its followers. The important fact is that they never calculated average incomes. From captain to cabin boy every member of every crew had his mind constantly fixed on the uncommon voyage - the "greasy" voyage which the skilful master and the "lucky" ship made every year. If the present voyage proved dry, no matter; the next would be greasy enough to make up for the present loss.

Nantucket people were not gamblers, for in spite of a lack of "meeting houses" that was shocking to Puritan ideas, they were deeply religious in their way; but some ships took more whales than others, and the thought of being one of the crew of a "greasy ship" - one that was filled with oil quickly -was fascinating. A man might, as some men did, make a year's wages in two months, and he would get his pay in a lump. Owners and crews were alike in this respect. All whalers eagerly "took chances"; they were under the sway of the gambler's instinct. 
62 The Story of the New England Whalers

It is a curious fact, worth mentioning here, that in the seventeenth century employers on land were sometimes fined for paying, and workmen were publicly flogged for accepting, higher wages than the law prescribed. The whalemen who went to sea for a "lay" were not subject to any such law.

If the owners be considered by themselves, it is found that they were doing pretty well even on the average. Their income compared very well with Mayhew's "twenty od pounds" profit on a voyage to the Bermudas. This is of interest because the increasing wealth of the owners was not a matter that excited, at that time, the envy of the forecastle men. It excited, rather, their emulation, because every ambitious forecastle man had opportunity to become an owner - to hold shares in ships. Ownership followed easily on the lay system of paying the crew. At the end of every "greasy" voyage the men drew more money than they needed for home and personal supplies (they drew it "in a lump," too), and it was the natural and usual thing for them to invest the surplus in the business wherein they had made 
it. Many a Nantucket capitalist began his investments in whaling ships by buying a five-dollar or a ten-dollar share. And this fact seems worth the consideration of those who would like to see the American high-seas fleet increased.

Although the whaler's opportunity for acquiring wealth has been considered first of all among the incentives which drew him into his career afloat, it is by no means certain that the call of greed was stronger on Nantucket than that of pride and ambition. John Paul Jones was not the only man of the eighteenth century who spelled rank with a capital $R$. In the slavers and freighters the ambitious youngsters saw abové them at most four posts of honor, - the berths of boatswain, second mate, first mate, and captain. By good work they could, in time, reach the highest rank, and the boy whose blood was not stirred at the thought of pacing a quarterdeck as captain of a ship was a "poor stick" indeed. So exalted did the position of captain seem that in their determination to reach it boys were known to wade barefooted through the snow from the farm to the wharf, where they might ship as foremast hands. 
64 The Story of the New England Whalers

And those barefooted boys worked their way aft to the berths of mates and captains with the rapidity, and with the ease and certainty, with which they climbed on a stormy night to the weather-topsail yard-arm when sail was to be shortened. "Bill" Phipps, the backwoods orphan boy, went to sea before the mast and in time came to be known as Sir William. Every ship's deck was 'then a pathway to honorable distinction, but in no other ship could an ambitious green hand gain rank so quickly as on a whaler; for the whaler carried more officers than any other ship, and the necessities of the work compelled the officers to give much attention to the training of the inexperienced.

The whale ship not only carried a captain and at least two mates, as other ships did, but it carried also a harpooner for every boat on the davits. And it was no small distinction to rank as harpooner on a successful whaler. In the work of killing a whale the harpooner stood up in the bow of the boat, as it danced and plunged over the waves; poised aloft the harpoon, and then hurled the weapon through the air with a might that drove 
it "to the hitches" into the body of the whale. On the accuracy and strength of the harpooner (and splendid courage was at the bottom of his skill and strength) the ship depended, first of all, for success in saving the whale.

It is particularly notable that the harpooner held the post of danger. The tossing flukes and the open jaws of the wounded monsters reached the man at the bow more frequently than any other of the boat's crew. And as the whale fled, dragging out the warp that was attached to the harpoon, the flying coils of the line caught many a harpooner and dragged him to death under the sea.

It is noted in most descriptions of whale killing that where the warp or harpoon line leaves the boat it passes through a wooden $\mathrm{Y}$ standing at the extreme bow. A small wooden peg was inserted through holes in the arms of the $\mathrm{Y}$ to keep the rope from flying out. This peg was a mere sliver which any Yankee could whittle to shape in two minutes; but the harpooners of Nantucket, when on shore and dressed for society (especially when dressed for a "squantum," as a picnic was called), wore those pegs as medals of 
66 The Story of the New England Whalers

honor. And every citizen of Nantucket, and of every other community where whalers were known, accepted the pegs as evidence of distinguished services afloat. The ambitious, agile youth on a freighter often served for several years before he was able to work his way aft to the berth of a second mate, but in the whale ship he often had opportunity during his first cruise to earn the right to wear the harpooner's badge.

Last of all, consider the secret society that the girls of Nantucket formed, a veritable Masonic order in its strength and beneficent influence, if we may believe the whaler annals. Though a man searched the ports of the wide world from Spitzbergen around both capes to the Sea of Okhotsk, he could find no girls to equal those of Nantucket Island ; and every one of them, obeying the precept of the ever present presiding genius of their society ("The Widow's Daughter?") was pledged not to marry any man until he had "struck his whale."

By its appeal to pride, ambition, greed - to the most powerful passions of the human mind - the pursuit of the whale drew every Nantucket 
lad to the sea, and there gave him the heart of a hero.

In I 7 I 2 Hussey showed the way to deep-water fishing. With every voyage thereafter the eager whalemen sailed farther from the home port. The Gulf Stream was reached, and abundant wealth was found there because of the whale food that floated along the edge of its current. The whalers were the first sailors to recognize the existence of this remarkable river of the sea, and through them all American captains learned to avoid it when westward bound across the Atlantic. They told the English captains about it, but for many years the proud Briton refused to take instruction from any colonial, even though Franklin (whose mother was a daughter of Peter Folger, a Nantucket whaleman) made a chart of the stream that had general circulation.

Cruising along the Gulf Stream the whalers went south to the Hatteras grounds, and on to the coast of Cuba. Cruising north and east they went to the Banks of Newfoundland and on to the waters about the Azores and Madeira, where a narrow space, quickly crossed, separated them from the grounds on the coast of Africa. 
68 The Story of the New England Whalers

In 1732 American whalers went to Greenland to hunt the whale among the ice fields off Cape Desolation, and it is recorded that "Capt. Atkins, returning from a whaling voyage thence, brought a Greenland bear." Crossing the equator they pursued the whales off the headlands of Brazil, along the desert coasts of Patagonia, and among the treeless Falklands. In I 767 no less than fifty New England whalers went to far southern waters "by way of experiment," as the chronicle says.

A table of dates of the extension of the Nantucket fishery, as found in the Merchants' Magazine, November, 1840 , is as follows:

The Island of Disco, in the mouth of Baffin's Bay, in the year $175 \mathrm{I}$.

Gulf of St. Lawrence, I76r.

Coast of Guinea, 1763 .

Coast of Brazil, 1774 .

It was when inspired by the enterprise of American whalemen thus exhibited that Edmund Burke, in his speech on Conciliation with America (now a schoolboy classic), said:

No sea but is vexed by their fisheries. No climate that is not a witness to their toils. Neither the perse- 


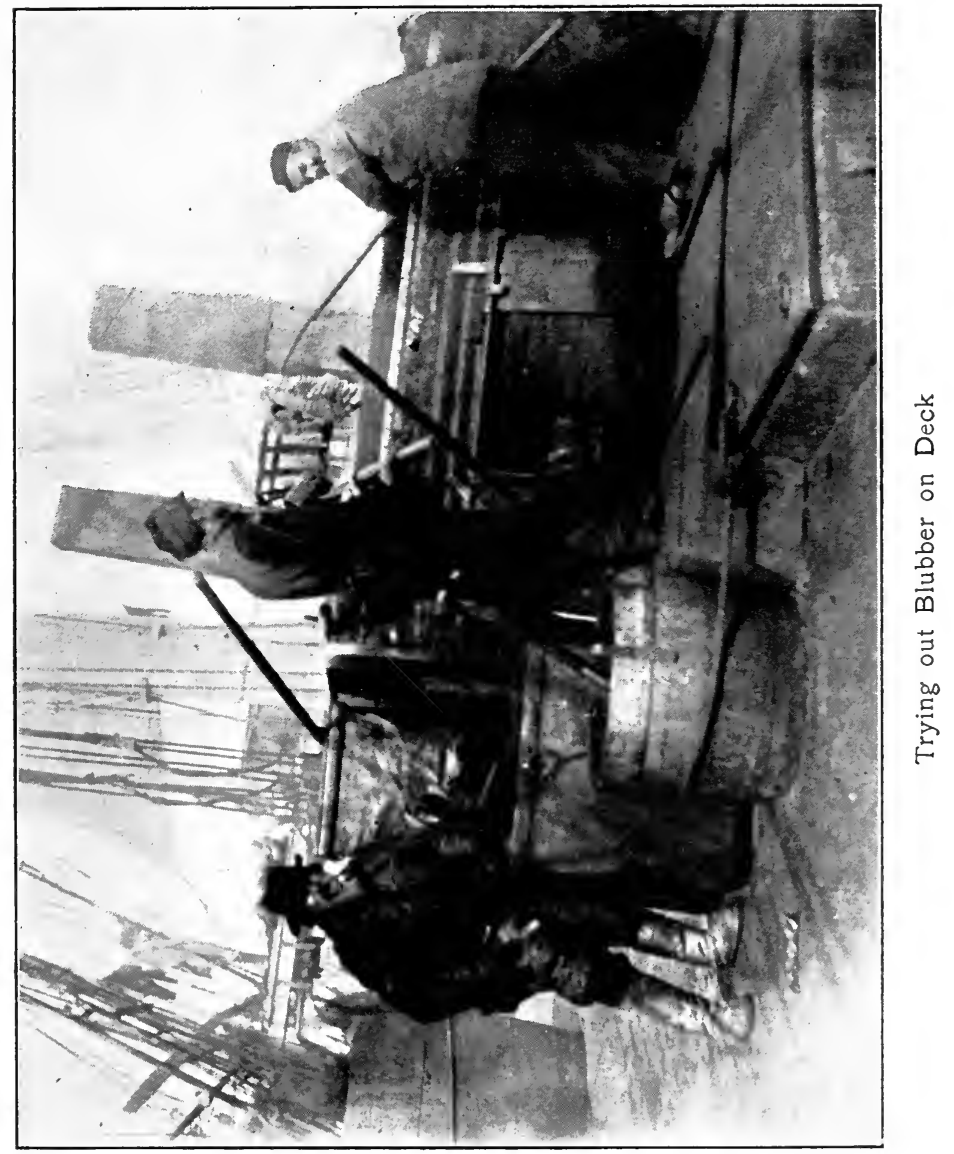



verance of Holland, nor the activity of France, nor the dextrous and firm sagacity of English enterprise ever carried this most perilous mode of hardy industry to the extent to which it has been pushed by this recent people; a people who are still, as it were, but in the gristle, and not yet hardened into the bone of manhood.

The market was sometimes swamped, for a time, by the flood of oil poured upon it by the successful whalers; but where others might be embarrassed, the people of Nantucket prospered steadily. In 1730 they began building their own ships. Captain Isaac Myrick launched a "snow" of I 8 tons during that year, a snow being a vessel having one square-rigged mast set at the midship section and another much shorter farther aft. Sloops and schooners of from 30 to 60 tons only had satisfied the Nantucket men theretofore.

In 1743 these whalers began to carry try-pots in furnaces built on their ships to try out the blubber as fast as it was saved, and larger ships were then needed for the longer voyages that this practice made possible. Yet the reader is not to think of any ship of the day as being large by any modern standard. An Erie canal boat carries 240 tons; 


\section{The Story of the New England Whalers}

it has twice the capacity of Captain Myrick's snow.

In I720 a small quantity of oil was shipped from Nantucket for sale in London. It brought a better price than the Boston buyers could afford to pay, and the cordage, canvas, iron, etc., which were purchased with it, were much cheaper than the same goods in Boston. This led, by slow degrees, to the establishment of regular direct trade relations with London. During the wars that afflicted the seas between the years 1740 and 1762 the American whalers were much troubled by the cruisers and privateers of the enemy, and by pirates also; but when they heard the reverberations of the guns at Quebec, they made haste to go whaling in the Gulf of St. Lawrence; and while commissioners were considering terms of peace in Paris, in 1762 , seventy-eight whalers cleared from American ports, of which more than half were from Nantucket. The year of i 766 saw I 8 vessels, measuring 75 tons each on the average, clear from Nantucket alone. They brought home II,969 barrels of oil valued at $\$ 129,983$. In 1770 the Nantucket fleet numbered 125 ships 
of the average size of 93 tons. During that year they took 14,33 I barrels of oil worth $\$ 358,200$.

The ship owners of other ports, seeing Nantucket's prosperity, had tried to share in it. Their success was fairly good, but Nantucket owned at this time as many whale-ships as all the other ports of America combined. The whale-ship owners of the other ports were obliged to send to Nantucket to get men fit to serve as captains and mates. The Nantucket men accepted the offers thus made, but they were Nantucket men still; for they called all the inhabitants of the mainland "Coufs," an uncomplimentary designation they had learned from the Indians.

Travellers from Europe, in those days, were astonished to find that America was a land where "no one begged." To its lasting honor Nantucket was a community not only where no one begged, but where every man was a laborer, and where every man was a capitalist, or, at worst, had capital within immediate reach.

"It is a fascinating theme. Nowhere in the whole history and evolution of peaceful commerce has such actual romance emanated as glowed in 
72 The Story of the New England Whalers

the voyages and lives of these homely men. These common folk, in their contest with the monsters of the deep, easily paralleled the old life of viking and sea rover." (Weeden's Economic and Social History of New England.)

But the evil days of the War of the Revolution were now at hand. 


\section{IV}

\section{THE MINOR COLONIAL PORTS}

$7 \mathrm{HE}$ story of Nantucket is by no means completed, but before going on with it some account of the whale fishery at other ports in the early days will prove of interest.

Whales haunted the whole New England coast. They were often seen in Buzzard's Bay and all the length of Long Island Sound. Indeed, there is an account of one that worked its way up the Hudson River as far as Cohoes. As on Nantucket, the settlers everywhere alongshore were farmers, woodsmen, and mariners (half horse, half alligator, was the description applied to such men in the Mississippi Valley), who promptly went in pursuit of the oil-bearing monsters whenever good opportunity offered. And of course the whales that drifted ashore were saved - with some bickerings over the ownership, as a rule. At Cape Cod and on Long Island the pursuit of whales became 
74 The Story of the New England Whalers

a regular business while yet the Nantucket people were content merely to save those that floated ashore. There were many whalers elsewhere. Salem was a whaling port of some importance as early as I 700. The records of Martha's Vineyard show that whales were killed alongshore in 1702. The Rhode Island sailors went in pursuit of whales at an early date, and in I73I the colony's assembly offered a bounty of five shillings for every barrel of whale oil and a penny a pound for bone taken by Rhode Island vessels and carried into the colony. The sloop Pelican, Captain Benjamin Thurston, was the first vessel to receive the bounty thus offered. She brought II 4 barrels of oil and 200 pounds of bone to Newport in 1733 .

In 1738 Captain Benjamin Chase, a successful Nantucket whaler, moved to Martha's Vineyard, intending to build up the whaling business on that island. He bought twenty acres of land on Edgartown harbor, built a wharf, and erected try-works. In the meantime he sent his sloop, called the Diamond, to deep water after whales. But a change of residence brought a change of luck; he failed. Between 1738 and 1744 three other capi- 
talists, one of whom had made a success on Nantucket, went to Martha's Vineyard to establish the fishery at Edgartown, and all failed as Chase had done. Then the tide turned and Edgartown was for more than a hundred years a moderately successful whaling port.

More important than any or all of the other minor ports of that day was the settlement which eventually developed into the famous port of $\mathrm{New}$ Bedford, on Buzzard's Bay. The land where New Bedford now stands was bought of the Indians by William Bradford and others in 1652 . The first settlers were nearly all driven away by King Philip's War; but when peace was made they returned and prospered. Remembering that Nantucket was first settled through the persecution of the Quakers, and that as it increased in population nine-tenths' of the inhabitants were of that liberty-loving sect, it is interesting to note that the people of the New Bedford region were for the greater part Quakers, and that their settlement first acquired notoriety in New England through their persistent refusal to support a minister of the Puritan creed. When the General Court 
76 The Story of the New England Whalers

levied a tax of $£$ roo, though the tax roll did not mention the purpose for which it was to be used, the Quakers saw that it would be given to a Puritan minister and refused to pay it. It was not a matter of money with them. They at once raised $£ 700$ with which they prosecuted an appeal to the home authorities, before whom they won.

It was this band of stiff-necked religious independents that established the whale fishery at New Bedford. One may suppose that the bulldog persistence of the Quaker in his fights for principle was at the foundation of his success in the whale fishery. A friend of the sect might go farther, perhaps, and say that while the standards of right and wrong of those days differed widely from the modern, yet even then the Friends chose whaling rather than the slave trade, and coastwise smuggling. And since they could not in good conscience sail on either a naval ship or a privateer, their innate love of a good fight had to find vent somewhere, and the whale fishery proved the most exciting resource.

The first settler on the territory now occupied by New Bedford was named Joseph Russell. 
He was a ship carpenter, as well as a farmer and fisherman, and with his two sons, Joseph and John, got afloat a number of vessels that were sent whaling offshore. The blubber was brought back to the Russells, who built try-works on the Acushnet River. The business prospering, works for refining sperm oil were erected, and then (1765) Captain Joseph Rotch, a Nantucket whaler with capital as well as experience, joined the Russells on the Acushnet, bringing with him several whaling vessels.

Rotch's reason for joining the Russells rather than locating on the more populous Apponegansett River may be noted here for future reference. The harbor was "deeper, broader, and safer." Rotch had reason for paying especial attention to the character of the harbor.

The glimpses which one may get in the records of the early whaling from Buzzard's Bay are all of interest. For instance, a part of the log of the whaling sloop Betsy, of Dartmouth (the name of the village on the Apponegansett), is preserved in Ricketson's History of New Bedford.

“Aug. 2d, I761, saw two sperm whales; killed 
78 The Story of the New England Whalers

one. - Aug. 6th, Spoke with John Clasbery; he had got 105 barrels; told us Seth Folger had got I50 barrels; spoke with two Nantucket men; they had got one whale between them; they told us that Jenkins \& Dunham had got four whales between them."

The whale ships often cruised in pairs, working as partners. The vessels were then small, and carried only one whale boat each. A single whale-boat crew could and did kill many a whale; but with two whale boats working together to kill a whale, the chances of success were more than doubled. Moreover, if the first boat to strike a whale happened to be crushed by the whale, the second boat would be at hand to rescue the crew. The crew of a boat working alone had to wait for the ship to come to the rescue.

There is no record of a crew of a whale boat being lost at that time through working alone, but there are tales of tragedies among the whalers from Buzzard's Bay. Thus in 1764 , Jonathan Negers, of Dartmouth, was so badly hurt when a whale struck his boat that he died a few days later. No details of the event are given. A 
more graphic tale is found in the Boston News Letter of August 18, I766: "Capt. Clark on Thursday Morning last discovering a Spermaceti Whale near George's Bank, manned his boat and gave chase to her, \& she coming up with her jaws against the Bow of the Boat struck it with such Violence that it threw a son of the Captain, (who was forward ready with his Lance), a considerable Height from the Boat, and when he fell the Whale turned with her devouring Jaws opened, and caught him. He was heard to scream when she closed her Jaws, and part of his Body was seen out of her Mouth when she turned and went off."

It appears that while the Nantucket whalers were cruising far to the south, the Buzzard's Bay men had a particular liking for the northern waters. The whaling vessels bound for the northern grounds were commonly fitted out for codfishing as well as whaling, - a division of interests that was profitable enough, but one that accounts for the superior growth of the Nantucket whaling interests. Having the cod-fish as a resource in case of failure in whaling, the ships with two out- 
80 The Story of the New England Whalers

fits were not likely to be as eager in the chase of a whale as those that had to get whales or nothing.

In 1765 the northern whalers ran foul of the authorities appointed by the Crown for the government of Newfoundland and the Labrador coast. A company had been chartered in London to carry on whaling, cod-fishing, and trading with the Indians on the coasts of Labrador. At the instigation of this company, Governor Hugh Palliser, of Newfoundland, issued a set of rules for the conduct of the colonial vessels coming to the coast. They were not "to fish for any other than Whales on this coast." When a whale was stripped of its blubber, the captors were to tow the "lean" at least three leagues out to sea because, as it was believed, the floating of a carcass alongshore drove away the cod. All fishing on the Newfoundland coasts was prohibited, and the trade with the Indians was restricted.

To enforce the obnoxious rules the sloop-ofwar Zephyr, Captain John Hamilton, was sent cruising alongshore. She boarded the colonial vessels she met and confiscated their catch of 
cod-fish, thus ruining their voyages. Worse yet, in the view of these sturdy colonials, was the haughty and insolent bearing of the Ziephyr's captain. Furthermore, two vessels that had been fitted out by the London company joined the sloop-of-war in her raid, and profited much by robbing the fishermen of their hard-earned fares.

On an appeal to the king he sustained the rights of the colonists to fish and trade on those coasts, but Governor Palliser was still able to forward the interests of the London people. Another proclamation was issued in which it was declared that the cruisers on the coast were to afford every protection and encouragement to the colonial fishermen. At the same time, however, the colonial ships were to be "under certain necessary Restrictions." Thus they were not to land to cut up whales and save the oil. To justify still further interference with the colonials it was asserted that they were in the habit of "plundering whoever they find on the coast too weak to resist them; obstructing our Ship Adventurers from Britain, ... destroying their fishing works on shore, stealing their boats, Tackle and Utensils, 
82 The Story of the New England Whalers and hunting for and plundering, taking away or murdering the poor Indian Natives of the country." Because of "these Barbarities, and other Notorious Crimes and Enormities" the cruisers were "to apprehend all such offenders" and to "bring them to me to be tried for the same."

As the Governor was at once prosecutor, judge, and jury, many of the colonial whalers were driven from the coast to deep-water fishing. It was an event that was not without influence upon the Revolution that was then at hand.

Nevertheless, further petitions brought a real modification of the rule, and in $\mathbf{I} 768$ eighty whalers from Nantucket, and as many from the other ports, went to the northern grounds. This proved a notable year for natural disasters. Ten of the Nantucket ships were lost and the fleet from other ports suffered as badly. Captain Hamilton, who, during this year, was in the Merlin sloop-of-war, saved two Nantucket crews. The catch of the survivors ran from 100 to 200 barrels of oil.

To complete the record of the whalers in the 
days before the Revolution it is necessary only to quote from a report, dated February 2, I79I, which Thomas Jefferson, Secretary of State, made to the House of Representatives regarding the whale and cod fisheries. A table in this report shows the "State of the Whale Fishery in Massachusetts from I77I to I775." It is the only statistical record of the fishery for that period, and it is as follows:

\begin{tabular}{|c|c|c|c|c|c|c|c|}
\hline $\begin{array}{l}\text { Ports from which the } \\
\text { equipments were made. }\end{array}$ & 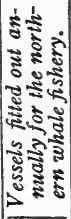 & $\begin{array}{c}\text { Their } \\
\text { tonnage. }\end{array}$ & 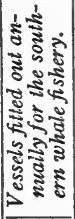 & $\begin{array}{l}\text { Their } \\
\text { tonnage. }\end{array}$ & $\begin{array}{l}\text { Seamen } \\
\text { em- } \\
\text { ploy- } \\
\text { ed. }\end{array}$ & $\begin{array}{l}\text { Barrels } \\
\text { of sper- } \\
\text { maceti } \\
\text { oil taken } \\
\text { annu- } \\
\text { ally. }\end{array}$ & 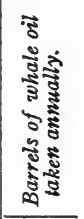 \\
\hline Nantucket & 65 & 4,875 & 85 & 10,200 & 2,025 & 26,000 & 4,000 \\
\hline Wellfleet & 20 & 1,600 & 10 & 1,000 & 420 & 2,250 & 2,250 \\
\hline Dartmouth & 60 & 4,500 & 20 & 2,000 & 1,040 & 7,200 & 1,400 \\
\hline Lynn [yard, & I & 7.5 & $\mathbf{I}$ & 120 & 28 & 200 & 100 \\
\hline Martha's Vine- & 12 & 720 & & & 156 & 900 & 300 \\
\hline Barnstable & 2 & 150 & & & 26 & 240 & \\
\hline Boston & 15 & $\mathbf{1}, 300$ & 5 & 700 & 260 & 1,800 & 600 \\
\hline stable County & 4 & 300 & & & 52 & 400 & \\
\hline Swanzey & 4 & 300 & & & $5^{2}$ & 400 & \\
\hline Total & 183 & 13,820 & I 2 I & 14,020 & 4,059 & 39,390 & $8,65^{\circ}$ \\
\hline
\end{tabular}

From this it appears that Massachusetts owned 304 whalers. Crews numbered from I3 to I4 
84 The Story of the New England Whalers

for each ship, and in the aggregate 4059 men were employed. The right whales gave ten pounds of bone for each barrel of oil. Onefourth of the oil of the sperm whales came from the head. This sold for $\$ I 50$ a ton, or $\$ I 8.75$ a barrel. Plain sperm oil sold for $\$ 100$ a ton and right whale oil, which was darker and of a rank odor, brought $\$ 50$. Whalebone sold for 15 cents a pound. The number of ships in the whale business that were owned outside of Massachusetts in the year' 1775 was between 50 and 60. Rhode Island and Connecticut owned most of them. The average size of a whaler of those days was 90 tons. They would be called small smacks in these days, but they braved the fiercest hurricanes of the seas, and those that were well handled often paid for themselves in the first voyage, leaving all subsequent catches as clear gains. 


\section{V \\ NANTUCKET IN THE WAR OF THE REVOLUTION}

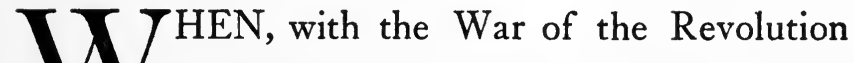
at hand, the Americans began arming themselves, and the British authorities were considering plans for coercing them, a committee of the House of Parliament was directed to consider the condition of affairs among the people of Nantucket. The facts related before this committee proved so interesting to the British public that Dodsley's Annual Register of London (1775) printed a résumé of the testimony from which the following paragraph is taken:

"The case of the inhabitants was particularly hard. This extraordinary people, amounting to between five and six thousand in number, ninetenths of whom are Quakers, inhabit a barren island, fifteen miles long by three broad, the 
86 The Story of the New England Whalers

products of which are scarcely capable of maintaining twenty families. From the only harbor which this sterile island contains, without natural products of any sort, the inhabitants, by an astonishing industry, keep ${ }^{4} 40$ vessels in constant employment. Of these eight are employed in the importation of provisions for the island, and the rest in the whale fishery; which with an invincible perseverance and courage, they have extended from the frozen regions of the Pole to the coasts of Africa, to the Brazils, and even to the Falkland Islands; some of those fishing voyages continuing for twelve months."

Here was an island thirty miles offshore that was dependent on the mainland for its daily bread, and yet there was not a gun mounted, nor was there any other means of making a defence if the enemy should come. And if a blockade were established, starvation or submission was inevitable.

As the reader will remember, Parliament was considering a bill "to starve New England" into subjection by "restricting colonial trade to British ports" and placing an embargo "on all fishing 
Nantucket in the War of the Revolution 87 along the American coasts." The Quakers of England interceded in behalf of their Nantucket brethren; but the bill passed 215 to 6I, and war became inevitable. The people of Nantucket had kept in touch with the political movements of the day, of course, and yet they were by no means prepared for war when it came. Their ships were out cruising for whales as usual, and their coasting vessels were plying to and fro, carrying oil to Boston and bringing food and other supplies to the island. The coasters were easily provided for, when war came; but the sound of the shot that was fired at Lexington, and was "heard around the world," was a long time reaching many of the whalers. In some cases, British cruisers took the echo to them with a summons to surrender that was not to be disobeyed. Those that escaped this misfortune hastened home as soon as they learned that war had been declared.

The story of the Nantucket whalemen during the years of war is tragic. The ships that reached home were no safer than they were on the high seas; they were not as safe, in fact. The British 
88 The Story of the New England Whalers

having a great navy were able to blockade the American coast and raid the American ports as well as scour the high seas. They burned ships at the wharf (fourteen at the first dash), and storehouses upon the land at Nantucket. The people of the little island were at the mercy of the invader, but they fitted out such vessels as escaped the invader and went to sea again and again in pursuit of whales until the fleet was almost entirely wiped out.

A number of the inhabitants migrated to the mainland, most of them naturally settling in ports of the mainland. Some of those who remained, preferring their island home to any other as long as they could live upon it, went afloat in rowboats to search for whales in the early fashion. Others manned blockade-running boats (the enemy did not occupy the island all of the time, but had cruisers near it much of the time) and carried on a traffic with and between the ports of the mainland. One reads in the histories of many venturesome deeds done by whale-boat men during the Revolution.

Meantime, to quote the words of Weeden, 
Nantucket in the War of the Revolution 89 some of the Nantucket men "occupied themselves in the common and inferior work of catching cod and mackerel in the nearer waters. The scarcity and high prices of salt took away the profit here. They tried making salt from the Atlantic sea water, but the fogs around their island gave them a too infrequent sunlight. As the war developed, West India produce became dear, and the whalemen engaged in this commerce."

The fact that Nantucket men thought the fishing for cod and mackerel common and inferior work and the West India trade something worth consideration only when war had brought them to the verge of starvation, is illuminating.

A graphic scene in Moby Dick is that where Captain Ahab calls all hands aft and questions them as to their duty when a whale is seen. They reply that, first of all, they are to "sing out," and then at the word they are to "lower away."

"And what tune do you pull to?" asked the captain, and they replied with a shout, " $A$ dead whale or a stove boat!"

Men who had pulled to that tune took kindly 
90 The Story of the New England Whalers

to war, once they were afloat in an armed ship. Many Nantucket men shipped in the patriot navy. Buell's Fobn Paul Fones says that twentyfive Nantucket men were on the Ranger when she left Portsmouth. The privateers, however, were favored most of all. There is abundant reason for saying that out of the 1700 men who had manned Nantucket whalers before the war, some hundreds shipped on the privateers. They took kindly to a calling in which there was such a strong element of chance. The hope of good luck was strong within them, and not without reason. For in the preceding war with France one Providence, Rhode Island, privateer, Captain Abraham Whipple, had captured no less than twenty-three prizes valued at a million of dollars. The Nantucket men firmly believed and often said, "What man has done man can do."

In due time the British cruisers began to gather in the ill-armed, under-manned, venturesome privateers. Some were captured by armed British merchantmen, for dozens of the Yankee privateers went to sea when armed with only one cannon, and a four-pounder at that. In fact, 
Nantucket in the War of the Revolution 9 I while our histories of privateering make boast of the number of ships captured from the enemy, they omit mention of the number the enemy took from us. By a return made in 1778 in Parliament it appears that while American cruisers had taken 733 British ships, the British had captured 904 American ships.

It is a most interesting fact that whenever an American ship was captured by British cruisers, the crew were at once interrogated to learn where each man hailed from. A list was then made of all Nantucket men found on board, and these, when they had arrived in England, were offered good wages as well as liberty, provided they would ship on British whalers. Naturally some accepted the offer. When, however, not enough whalers were thus secured, the obdurate Nantucket men were fed on food of such poor quality and so scant in quantity that they felt obliged to eat snails and rats found in the prison to keep soul and body together. In time, these methods of persuasion having failed, the Nantucket men were taken from prison and compelled to choose whether they would go whaling or ship on a 
92 The Story of the New England Whalers

British man-o'-war and serve under the claws of the cat.

The British government had determined to establish a British whale fishery. As few British subjects knew anything about whale fishing, and because Nantucket men knew all about it, the authorities tried to compel the captured whalers to man the ships destined for this fishery, and not only secure the bone and oil wanted in the market, but at the same time build up a whalefishing population at some port in England. To encourage the owners of British ships fitted for this fishery, the government granted each ship a bounty of from $£ 500$ to $£ 1000$.

In a communication from the American commissioners in France (Franklin and John Adams), dated October 30,1778 , to M. de Sartine, is the following:

"The English last year carried on a very valuable whale fishery on the coast of Brazil and off the River Plate ... just on the edge of soundings, off and on. . . . They have this year about seventeen vessels in this fishery which have all sailed in the months of September and October. 
Nantucket in the War of the Revolution 93

All the officers and almost all the men belonging to these seventeen vessels are Americans from Nantucket and Cape Cod in Massachusetts, excepting two or three from Rhode Island and perhaps one from Long Island."

A list of twenty American captains of British whalers, as obtained from the officers of three of the whalers that had been captured by French cruisers, was added to the communication. Sixteen of the twenty were from Nantucket.

The commissioners suggested the sending of a French frigate to the Brazil coast to gather in that whaling fleet. Adams wrote home urging that an American frigate or sloop be sent to the same coast. In this letter he said:

"Whenever an English man-o'-war or privateer has taken an American vessel, they have given the whalemen among the crew, by order of government, their choice either to go on board a man-of-war and fight against their country, or go into the whale fisheries. Such numbers have chosen the latter as have made up the crews of these seventeen vessels."

There is no record of any attack upon this British fishery. 
94 The Story of the New England Whalers

In time the British, occupying Newport and New York, sent out privateers that broke up the despised cod and mackerel fishing of the Nantucket men, and drove the West India traders into narrow waters. In this desperate situation, in fact, to avert actual starvation, an effort was made to secure from the British authorities permits to go whaling. Timothy Folger and William Rotch were sent as envoys from the island to New York to negotiate for permits to set afloat twenty open boats for alongshore fishing, four deepwater whale ships, and ten small coasters to serve as packets for carrying food and fuel from the mainland. In 1781 Admiral Digby, commanding at New York, being moved by the statements of these envoys, issued permits for twenty-four whale ships to go to sea. ${ }^{1}$

${ }^{1}$ The following is a copy of one of the permits taken from Starbuck:

"L.S. By Robert Digby, Esquire, Rear Admiral of the Red, and commander-in-chief, \&c., \&c.

"Permission is hereby given to the brig Dolphin, burthen sixty tons, Walter Folger, owner, navigated by Gilbert Folger as master and the twelve seamen named in the margin, to leave the island of Nantucket and to proceed on a whaling voyage, - to commence the first of January, I782, and end the last 
Nantucket in the War of the Revolution 95

Of seventeen vessels that were fitted out during I78I under permits of this kind, two were carried as prizes to New York and one was burned in spite of the permits. The others made good voyages, and, in consequence, twenty-four were fitted out in 1782. Of these one was taken to New York in spite of her permit, and two were carried to Salem and Boston because of the permits. The New England privateersmen had learned about the Nantucket people having British permits, and, in spite of the well-known condition of the islanders, went cruising after the twenty-four whalers. The courts in Massachusetts released

day of - following, provided that they have on board the necessary whaling craft and provisions only, and that the master of said brig is possessed of a certificate from the selectmen of the said island, setting forth that she is bone fide the property of the inhabitants of the island, with the names of the master and seamen in her; and that she shall not be found proceeding with her cargo to any other port than Nantucket or New York.

\section{"Robert Digby.}

"Dated at New York the first day of December, I78I.

"To the commanders of his majesty's ships and vessels of war, as well as all privateers and letters of marque.

"By command of the admiral.

$$
\text { “Thomas M. Palmer." }
$$


96 The Story of the New England Whalers

the two thus taken, on the grounds of humanity, but their voyages had been ruined and they had no redress.

Finally (March 22, I783) the "draft of a passport" for the use of Nantucket whalers was reported to the American Congress and "agreed to" in such shape that the inhabitants were to be permitted to go whaling with British permits as well. The war, however, was now about at an end, and the measure had little effect upon the fortunes of the whalers.

To sum up the disasters that befell the people of Nantucket during the War of the Revolution, it appears that out of a fleet that numbered 150 vessels of all kinds, owned in the island before the war began, no less than I34 were captured by the enemy, while fifteen others were wrecked. So much for the property losses. Of the 800 families that were yet on the island at the end of the war, no less than 202 were the families of widows who had 342 children. With few exceptions the men of those families had lost their lives in fighting for their country. Over I200 Nantucket men were killed or captured in the course of the War of the Revolution. 


\section{VI}

\section{A LONG PERIOD OF DEPRESSION}

7 HE Nantucket whaler of widest repute at the end of the War of the Revolution was William Rotch. Manifestly he was a sincere Quaker and a typical whaleman of his day, for he would take no part in the fighting, and he would not let anything, not even repeated and enormous losses, interfere with the prosecution of his business enterprises. Thus, as noted, he was one of the men who went to New York to secure fishing permits from the British admiral. With Samuel Starbuck he went to Philadelphia to intercede with the American Congress for licenses to send ships to sea with British permits also on board, and he succeeded in that design. And when the Massachusetts privateers took a couple of whale ships into port for sailing under British licenses, he was one of the committee sent from Nantucket to argue before the court at Boston for the release of the captured vessels. 
Further than that, although his losses amounted to more than $\$ 60,000$ during the war, he built ships to replace those taken by the enemy, and he kept them cruising for whales. For perseverance under adverse circumstances, there was no man more noted in the annals of the whale fishery than Rotch.

As it happened, one of the ships of William Rotch returned to port just at the time, at the end of the war, when it became safe to send a cargo to Europe. She was at once ordered with oil to London. The appearance of a ship flying the American flag in that port created a decided sensation. Said a periodical of the day:

"The ship Bedford, Captain Mooers, belonging to Massachusetts, arrived in the Downs the $3 \mathrm{~d}$ of February, \& was reported at the Custom-House the 6th instant. She was not allowed regular entry until some consultation had taken place between the commissioners of the customs \& the lords of council, on account of the many acts of parliament yet in force against the rebels in America. She is loaded with 487 butts of whale oil; is American built; manned wholly by American seamen; wears the rebel colors \& belongs to the island of Nantucket in Massachusetts. This is the 


\section{A Long Period of Depression}

first vessel that displayed the thirteen rebellious stripes of America in any British port." 1

Another Nantucket ship, the Industry, Captain John Chadwick, arrived a few days after the Bedford. Both ships sold their cargoes to advantage.

The appearance of these two ships with American whale oil thus promptly after the end of hostilities, however, prepared the way for what seemed at the time the death-blow to the American whale fishery.

The British ship owners, who had been extending their fishery by the aid of Yankee whalemen captured during the war, protested against further importations of "rebel" oil, and a duty of $£ \mathrm{I} 8$ a ton was immediately laid upon all foreign oil. As the other European nations were also striving to foster their whale fisheries by means of protective duties, the American whalers were thrown back on their own home market.

${ }^{1}$ It is said (Starbuck) that one of the Bedford's sailors was humpbacked. One day while he was ashore one of the natives overhauled him, and, laying a hand on his back, said, "Hello, Jack, what have you got here?" - "Bunker Hill and be $d-d$ to you," replied the Yankee. 
Ioo The Story of the New England Whalers

As already noted, the War of the Revolution, together with unusual misfortunes in storms, had destroyed 149 out of 150 ships that were owned at Nantucket before the war began. The Buzzard's Bay and other whaling fleets had suffered almost as severely. The American people had waged a defensive war, for the enemy had come to the American coasts to do the fighting, and the raids alongshore that were thus made inevitable had wiped out ships, warehouses, the outfits stored therein, and the try-works. To add to the other misfortunes of the whalers, the market for whale products was almost ruined. Having no whale oil, the people of America had turned to substitutes, such as tallow candles. Even the lighthouses were in some cases compelled to use substitutes. It is likely that no other industry of the country suffered as much through the war as that of the whalers.

When the European market was closed to them the American whalemen found their oil, which cost them not far from $\$ \mathrm{I} 20$ a ton to secure, selling for $\$ 85$. Thereupon the Nantucket men applied to the Massachusetts legislature for a 
bounty to save the fishery from extinction. The legislature granted $£_{5}$ a ton on white sperm oil, $£ 3$ on yellow sperm, and $£ 2$ on whale oil "that may be taken or caught" by vessels "owned and manned wholly by the inhabitants of this Commonwealth."

The whalemen promptly fitted out their ships then, and brought home so much oil that the burden of the bounty became too great, and at the same time the market was depressed so far that the ships were worse off than they had been before the bounty was given them.

As early as 1764 , while yet the whalemen were subjects of Great Britain, the British authorities had contemplated establishing a whale fishery at Halifax or Quebec, but had been unable to induce the whalemen to migrate. They said that Quebec was not a suitable location; it was too far from the sperm grounds. As for Halifax, it had a military government, something heartily detested by all Americans, and what was of more importance, they had "so invincible an aversion to the loose habits and manners of the people, that nothing could induce them to remove thither, 
IO, The Story of the New England Whalers

even supposing them reduced to the necessity of emigration." 1

When, after the War of the Revolution, the one industry of Nantucket became depressed to a point where even such thrift as that of these islanders was not able to make a whale ship profitable, some of the inhabitants remembered the British attempts to establish whaling communities, and began to look abroad for opportunities that seemed to be denied them at home. With England and France paying bounties to their whalemen, these Nantucket men thought they might do better to migrate to Europe. Chief among those who thus determined to abandon their old home was William Rotch. Leaving the island

${ }^{1}$ It is related that a young whaleman named Greene, mate of a Nantucket whale ship that had put into Halifax, had the audacity to interfere for the protection of a girl to whom the Duke of Clarence, admiral of the British fleet, was giving unwelcome attention, and when nothing else would protect the girl he took the officer by the coat collar and the seat of the trousers and threw him down a flight of stairs. The admiral (he was afterward William IV of England), on picking himself up, sent for the young whaler, intending to offer him a commission in the Royal Navy, but Greene had gone on board ship and would answer no summons from any naval man. 


\section{A Long Period of Depression}

on July 4, 1785, with the ship Maria, he went to London and applied to William Pitt, Chancellor of the Exchequer, for aid in transferring the whalers of Nantucket to some port in England.

Pitt allowed Rotch to wait in idleness for four months and then appointed Lord Hawksbury, "a gentleman not very favorably disposed toward America," to consider the matter. Captain Rotch asked Hawksbury for £Io0 sterling transportation for a family of five persons, and $£$ Ioo settlement.

"And what do you propose to give us for this outlay of money?" said Hawksbury.

"I will give you some of the best blood of the island of Nantucket," replied Rotch. He added that roo families would take advantage of such an opportunity to emigrate. Hawksbury calculated that a family could be transferred for $£ 87$ IOs., and he offered that sum. Captain Rotch arose to leave, saying, "Thy offer is no object."

"Well, Mr. Rotch, you will call on me again in two or three days," said Hawksbury.

"I see no necessity for it," replied the captain, and away he went. The next day Hawksbury 
I04 The Story of the New England Whalers

sent for him, and they "had the old story over again." Rotch told Hawksbury that a rumor was current to the effect that France had agreed to admit oil from Nantucket.

"If there is any such contract sufficient to retain us at Nantucket, neither you nor any other nation shall have us," said he. "And if it is insufficient, I will endeavor to enlarge it."

"Ah, Quakers go to France?" said Hawksbury.

"Yes, but with regret," replied the captain. Thereupon he went to France. Hawksbury then became suddenly anxious to secure the whalers and wrote to Rotch, offering to give all the money asked, and to allow the whalers to bring in forty of their ships; but Rotch refused to have anything more to do with him. In Paris Rotch found a kindly reception.

"I had a separate interview with all the ministers of state necessary to the subject, five in number," wrote Rotch (the quotations are from a Rotch manuscript first published by Starbuck), "who all agreed to and granted my demands. This was effected in five hours." 


\section{A Long Period of Depression}

The concessions thus secured allowed the Nantucket whalers to have "an entire free exercise of their religion"; a tract of land for homes, storehouses, and a dry-dock; the importation of all whaling products and of food supplies free of duty; all bounties and other privileges allowed to native fishermen; an additional premium per ton on the burden of their vessels engaged in the whale fishery; liberty to command their own ships and select their own crews; freedom from military duty in time of war as well as peace. An additional duty was to be laid on all oil that might thereafter be brought from foreign nations. According to Jefferson's Report, "Nine families only of thirty-three persons accepted this invitation" from France. Rotch was among the number.

In the meantime the British authorities had been negotiating directly with Nantucket to induce some of the whalers to go to Nova Scotia, and with so much success that a ship was sent to carry away the emigrants. While the ship lay at the wharf, however, a letter was received from Lafayette, asking the people not to move until they 
ro6 The Story of the New England Whalers

should hear further from France. This letter had so much influence that only two families went away in the British ship.

The publication of Jefferson's Report, however, while the facts are as stated, has created a wrong impression as to the condition of affairs on Nantucket during that period. For, while only the few left at the times mentioned, a considerable number of whalers went to Nova Scotia later and established themselves at a settlement on Halifax Bay, which they named Dartmouth, - a fact that indicated the presence of a number of Buzzard's Bay whalers in the community. Others went to Milford Haven, England. A Catalogue of Nantucket Whalers, issued by Hussey and Robinson of Nantucket, in 1876, gives a list of 149 Nantucket captains who commanded British whale ships "prior to 1812." It is certain that many of the mates and harpooners, and some of the seamen on these ships, were also Nantucket men; for when Commodore Porter, in the American frigate Essex, destroyed the British whale fishery in the Pacific Ocean, he found several of the crews so made up. The Nantucket captains of French 
whalers numbered $8 \mathrm{I}$ at the same period. Both England and France got some of what Captain Rotch called "the best blood of Nantucket."

To complete the story of Captain Rotch, it appears from manuscripts quoted by Starbuck that he had to return to America eventually. He wrote:

"In the beginning of I793 I became fully aware that war between England and France would soon take place, therefore it was time for me to leave the Country in order to save our vessels if captured by the English. I proceeded to England. Two of them were captured, full of oil, and condemned, but we recovered both by my being in England, where I arrived two weeks before the war took place. My going to France to pursue the whale fishery so disappointed Lord Hawksbury that he undertook to be revenged on me for his own folly, and I have no doubt gave directions to the cruisers to take any of our vessels that they met with going to France. When the Osprey was taken by a King's ship the officer sent on board to examine the papers called to the captain \& said, 'You'll take this vessel in, sir; she belongs to William Rotch.", 
108 The Story of the New England Whalers

Rotch had lived eight years in France. He remained only one year in England. He then returned to Nantucket, but found a welcome that did not please him, and a year later he moved to New Bedford, where he died in 1828 . It appears, however, that members of this family continued to reside in France, and to maintain a whaling fleet there until 1855. Other vessels belonging to the Rotches were sailed out of England for a long time after William Rotch returned to America.

The fact that Rotch was not heartily welcomed in Nantucket is interesting. The people of Nantucket as a whole loved the Stars and Stripes, as the emblem of a nation; they had a pride in their skill as something peculiarly American. They regarded the emigrants as deserters, and from the day when William Rotch sailed away in the Maria, they openly denounced the migrants.

In fact, while Rotch was preparing to sail, Captain Alexander Coffin, a leader of the patriots, wrote (July 8, I785) to Samuel Adams to invoke legislation against the emigrants. He said (letter quoted by Starbuck) that Captain Rotch "is now taking on board a double stock of materials, 


\section{A Long Period of Depression}

such as Cedar boards (commonly called boat boards), of which they have none in England, a large quantity of cooper's stuff for casks, \&c. Neither does it stop here. The house of Rotch have been endeavoring to engage an acquaintance of mine to go to Bermudas to superintend the business at that place. . . O One of the company is now at Kennebeck, contracting with some persons for an annual supply of hoops, staves, and other lumber necessary for the business." In consequence of Coffin's letter, Massachusetts forbade the exportation of the materials that Rotch was taking.

The depression which drove Rotch and his associates from Nantucket was by no means ended when Rotch returned to America. The weakness of the American republic and the disordered conditions in Europe due to the French Revolution bore heavily upon the American whalers. Pirates and piratical privateers swarmed from the ports of the West Indies. Some of the whalers were captured and others were driven from the sea by the danger of capture. The good fighting done by the little American navy in the 
I Io The Story of the New England Whalers

quasi-war with France ended to a large extent the depredations of the French pirates; but the American foreign policy was changed after the end of that war. Under the new administration (Jefferson's), the aggressions of European belligerents were to be stopped by a policy of "peaceable coercion." The American government thought it possible to compel the British, during the war with Napoleon, to grant "free trade" to American ships by a threat to cease buying certain British goods, such as beer, playing cards, etc., in case the grant were not made. When an American warship was attacked upon the high seas and a part of her crew carried away by a British frigate, the American administration avenged the outrage by laying an embargo on all American shipping! No other part of the history of the American people is so exasperating to a modern patriot as that relating to the period between I8OI and I8I2.

Naturally an embargo upon American shipping was wholly ruinous to the whalers, and it was during the embargo period that most of the whalemen whose names appear in the list of captains of foreign whale ships emigrated. Finding it 
impossible to follow their calling at home, they went to England and secured employment, even though the British authorities were then treating the American people with a degree of injustice not yet forgotten. Because the British had a strong navy and knew how to use it, the British whale fishery flourished while the American whale fishery was depressed beyond measure.

And yet during the long period between the War of the Revolution and the end of the War of I8I2, those who, like the people of Nantucket, could build, and fit out, and man their own ships with their own labor and resources - without borrowing capital - had a fair chance to make a living, and a few of the more enterprising, skilful, and fortunate could and did do something more. ${ }^{1}$ The business as a whole, however, was of very little consequence as compared with what it had been in the good times before the Revolution.

Between I789 and I8I5 one notable advance was made by the American whalers: they increased the size of their ships up to 300 tons. The greater

${ }^{1}$ The following account of a voyage made by the ship Lion of Nantucket shows how owners made money when every- 
II The Story of the New England Whalers

economy found in the use of larger ships, together with the discovery of new fields, really saved the American whale industry from extinction.

And yet, curiously enough, the progress that called for larger ships sounded the death knell of the Nantucket whale fishery. The myth of the red whalers was true, - Nantucket was a moccasin full of sand thrown out to sea by the giant thing went well. The "owners' share was much more than the ship was worth" (quoted by Weeden):

Ship Lion, Nantucket, 1807

DR.

CR.

To am't charge

Sundry acc'ts in clearing ship . . . . .

Share of captain, I/I8

Share of mate, $1 / 27$.

Share of second mate, I $/ 37$. . . .

Share of 2 ends men, each, $\mathrm{I} / 48$...

Share of 5 ends men, each, $\mathrm{I} / 75$. . .

Share of cooper, $\mathrm{I} / 60^{\circ}$

Share of boy, I/I 20 .

Share of 5 blacks, each, I $/ 80$.....

-Share of I black, on 400 bbls., I/80 . .

Share of I black, I/90

Share of 1 black, I/85

Share of I black on all but 400 bbls., $x / 90$

Ownes' share . . . . 24,252.74

$\$ 362.75$

2,072.13

$\mathrm{I}, 38 \mathrm{I} .4 \mathrm{I}$

I,008.06

I,554.10

$2,486.55$

621.64

310.82

2,33I.I4

108.36

414.42

438.80

318 . 10
By $37,35^{8}$ gals. body oil • . \$I9,766.r4

By 16,868 gals. head matter . I7,849.73

By $5_{50}$ gals. black oil . 
forces of nature. The arms of the crescent, in which the island took form, provided a very good shelter from sea and wind, once a ship had arrived within the embrace. But across the mouth of the harbor lay a bar upon which the water was never more than ten feet deep. When the Nantucket people began deep-water whaling with 30-ton sloops, the harbor was excellent for their purpose. When the ships had reached a size of roo tons and more, however, trouble began. In pleasant weather lighters were sent off to receive so much of the cargo as was necessary to lighten the ship to a point where she could enter. In foul weather the ships went to Martha's Vineyard and to mainland ports to shift cargoes.

By their ingenuity the Nantucket whalers kept afloat, but the lightering was expensive. Moreover, there were dangers to be considered in connection with such work. Accordingly, in 1803, when many of the Nantucket ships were so large that they could scarcely cross the bar, though in ballast only, the people of the island made an appeal for help to the national government. The document can be found in Volume X, American 
II4 The Story of the New England Whalers

State Papers, pp. 526-527. In it the story of the Nantucket fishery is told briefly; reference is made to the large bounties which were then paid by the British and French governments to sustain their whalers, and then, with these facts for an argument, the Nantucket whalers asked "that Congress would grant them the nett revenue collected in Nantucket as a fund to enable them to extend piers into the sea, so as to form a narrow channel which might be deepened and would, (as they conceive,) be kept deep, when so confined, by the rapidity of the tide flowing in and out." .

A more modest or a more worthy petition for national aid cannot be found in the archives of the nation. They asked only that they might retain for a time their own contributions toward the support of the general government and use the money to increase their facilities for doing their peculiar business, and thus increase their ability to make greater contributions to the support of the government.

Further than that, here were a number of plain but observing sailors, men without scientific training, proposing the very means for cutting 


\section{A Long Period of Depression}

away sandbars which brought fame to the celebrated engineers who deepened the water at the mouth of the Mississippi, and gave to Charleston, South Carolina, a new, deep, and permanent channel to its harbor.

The modest petition of the Nantucket whalers was considered by a committee of Congress. The committee reported that they reflected "with great pleasure on the enterprise and skill with which the inhabitants of Nantucket have pursued the whale fishery; affording an admirable example of zeal and industry to all nations of the earth," and then resolved, "That the inhabitants of the island and town of Nantucket ... have leave to withdraw the said petition."

In 1806 the whalers came once more to Congress for relief. They pointed out the disadvantages under which they labored because of the necessity of taking their ships to other ports to discharge the oil into lighters, and then said:

"Add to this the collectors of the customs charge the fees of office in each collection district, although the ships have no foreign goods on board, so that whaling vessels are almost always compelled to pay double custom house expenses." 
I 6 The Story of the New England Whalers

A committee of Congress considered this appeal; it also listened to the politicians ("good fellows," every one, beyond a doubt), who held the offices of collector of customs at the ports involved, and then declared that "it would seem to be fair and reasonable that the collectors of customs should receive their regular fees in transacting all their official business"; because, forsooth, "the fishery is profitable to those who carry it on," and the payment of double fees "cannot operate, in any essential degree, as a discouragement."

In I806 thirteen whale ships cleared from Nantucket and eight cleared from New Bedford, the port next to Nantucket in the extent of its whaling business. In 1818 Nantucket sent eighteen whale ships to sea; New Bedford, twentyfive. In 1846 (called the "boom year" of whaling) sixteen whalers cleared from Nantucket and sixty-nine from New Bedford.

In 1839 the whalemen of Nantucket made a supreme effort to overcome the disadvantages of a shoal bar at the harbor entrance by building a steam "camel." This camel was a floating dock that was able to travel in and out of the harbor 
with its own motive power. It was large enough to pick up a loaded whale ship and carry it across the bar. Though it was used for the purpose intended, it was not a practical success, and it was, in time, abandoned.

In I857 four whale ships cleared from Nantucket and ninety-five from New Bedford. New Bedford at that time owned 329 whale ships; Nantucket owned only forty-one, and these were handled chiefly from other ports. In I874 Nantucket's name disappeared from the list of American whaling ports. Because only ten feet of water was found on their harbor bar at best, the whalers who taught their arts to the whaling world were béaten at last and compelled to emigrate to other ports where the water was deeper.

The story of the American whalers during the War of 18I2, though brief, is interesting. At the beginning of the war Nantucket owned fortysix whale ships. Of these about twenty sailed for the Pacific in the year I8II. New Bedford sent one ship to those grounds, the Barclay, Captain Gideon Randall. These ships were yet on the Pacific when the war began, and that fact was 
I 8 The Story of the New England Whalers

well known to the Nantucket renegades who were in the British whale fishery. Accordingly, the renegades secured letters of marque, armed their ships, and sailed for the Pacific to prey on their former friends and neighbors. One of them was so eager for plunder that he did not wait for a commission; and he was caught plundering in a way that would have justified the American authorities in hanging him as a pirate. However, the appearance of the United States frigate, Essex, under Commodore David Porter, in the Pacific, not only released the American whalers that the renegades had captured, but all of the British whale ships except one were taken, and the one was compelled to lie idle in harbor while Porter was making his famous cruise.

The story of the whaler Barclay and Captain Randall is worth giving in some detail because of his connection with the first admiral of the American navy, David Glasgow Farragut, on whom he tried to play a practical joke, with results that Farragut remembered all his life.

While at work off the coast of Peru the Barclay was captured by a Peruvian corsair called the 


\section{A Long Period of Depression}

Nereyda. Spain (Peru was yet a Spanish possession) was not at war with the United States, but she was an ally of Great Britain in the war. with Napoleon, and the captain of the corsair thought that, as Britain's ally, he might lawfully prey on the valuable whale ships from New England. He found the Barclay almost full of oil, and taking out her crew he put some of his own men on her and sent her toward port. On the way, however, the Barclay fell in with a British whaling letter of marque, the captain of which soon learned the conditions prevailing upon the captured ship. The fact that the Barclay was then under the Peruvian flag was a matter of no importance to the British captain, for he promptly set the Peruvians ashore and took possession of the Randall.

Unhappily for him, however, the Essex came along and took both him and the Barclay. The Essex had taken the Nereyda, meantime, and released Captain Randall. Commodore Porter now offered to give the Barclay to Randall, but the crew of the Barclay had shipped on the Essex and declined to return to the whaler. The whaler 
I20 The Story of the New England Whalers

was therefore manned with naval seamen and kept in company with the Essex.

In due time, other ships having been captured, Porter found himself short of officers to place in command of the prizes, and in this emergency he ordered Midshipman David Glasgow Farragut to the command of the Barclay, although Farragut was only twelve years old. What happened after Farragut took command of the whale ship is told in the admiral's Memoirs:

"This arrangement caused great dissatisfaction on the part of the captain of the Barclay, a violent-tempered old fellow; and when the day arrived for our separation from the squadron [the Barclay was ordered to Valparaiso], he was furious, and very plainly intimated to me that I would 'find myself off New Zealand in the morning'; to which I most decidedly demurred. We were lying still while the other ships were fast disappearing from view.

"I considered that my day of trial had arrived (for I was a little afraid of the old fellow, as every one else was). But the time had come at least for me to play the man; so I mustered up courage and informed the captain that I desired the mainsail filled away, in order that we might close up with the Essex funior. He replied that he would shoot any man who dared touch a 


\section{A Long Period of Depression}

rope without his orders; he 'would go his own course, and had no idea of trusting himself with a $d-d$ nutshell,' and then he went below for his pistols. I called my right-hand man of the crew, and told him my situation; I also informed him that I wanted the maintopsail filled. He answered with a clear 'Aye, aye, sir!' in a manner which was not to be misunderstood, and my confidence was perfectly restored. From that moment I became master of the vessel, and immediately gave all necessary orders for making sail, notifying the captain not to come on deck with his pistols unless he wished to go overboard; for I really would have had very little trouble in having such an order obeyed.

"I made my report to Captain Downes, on rejoining him, and the captain also told his story, in which he endeavored to persuade Downes that he only tried to frighten me. I replied by asking Captain Downes how he succeeded."

It was a serious matter to the young naval officer, but the fact that Captain Randall said that he would find himself "off New Zealand in the morning," though New Zealand was on the farther side of the ocean, shows how the whaler really viewed the matter. The fact is that in those days it was the custom of whaler captains to take great interest in the youngsters on their own ships, and to train 
122 The Story of the New England Whalers

them in many ways. Captain Randall was but training the youth who was to do much for the honor of the flag later, and he was as much pleased as any one when the lad was able "at least to play the man." The Barclay was taken to Valparaiso, and she sailed thence for New Bedford, arriving there in March, I8I4, with 1800 barrels of oil.

The records show that Captain Randall, while in command of the ship George and Susan, "came home sick, I8I9." Thereafter he disappears from the record. The Barclay was in commission until I859, when she was "withdrawn," too old for further service, and was sent to the "bone yard."

When by good fighting afloat during the War of 1812 the American people gained the right to send their merchantmen to all parts of the earth unmolested by any power whatever, a new era dawned upon the whalers and upon all other American ships. 


\section{VII}

\section{ADVENTURES OF THE EXPLORERS}

I asked a maiden by my side,

Who sighed and looked to me forlorn, "Where is your heart ?" She quick replied, "'Round Cape Horn."

I said, "I'll let your father know,"

To boys in mischief on the lawn;

They all replied, "Then you must go

'Round Cape Horn."

In fact, I asked a little boy

If he could tell where he was born;

He answered with a mark of joy,

"'Round Cape Horn."

— Old "gamming" song.

THEN Nantucket men first went whaling in deep-water ships, the world was new in a way not now easily comprehended.

Spain had drawn a line across the South Sea from Panama and Mexico to Manila. Drake, Dampier, and a few other hardy souls had followed that 
I24 The Story of the New England Whalers

route in search of the annual treasure ship, - sometimes with success, - but outside of this thin line the mighty expanse of the Pacific was unknown. In I743-1 744 Admiral Lord Anson strove to take a squadron of six ships around Cape Horn to destroy the Spanish forces on the west coast of South America, but so great were the real dangers as well as the terrors of the passage that only one, the ship carrying the flag, succeeded. Admiral Bougainville, of the French navy, became famous as an explorer because he succeeded in sailing around the world a little later. It was on February I4, I779, that Captain James Cook, one of the most noted of the explorers of the Pacific, was killed at the Sandwich Islands, and it was not until I 79I-I 795 that Vancouver did the work that placed his name on the map of the northwest coast.

In the Atlantic, during the eighteenth century, the waters were, of course, better known. The slaver's three-passage route was followed often enough. There were packet lines from Spain to the West Indies and the river Plate, from France to the St. Lawrence (before the year 1762), and from England to her colonies. But only the 
American sailors had recognized the Gulf Stream, and wide breadths of the South Atlantic had never felt the cut of a keel. Indeed, as already noted, when Burke, in his speech on Conciliation with America (1775), wished to praise in highest terms the bold enterprise of the people of Nantucket, he told how they ventured in their whale ships to the Falkland Islands.

Terrors that were then very real seem foolishness now. As late as 1833 the sloop Fame, Captain Peter Myrick, of Nantucket, sailed (July 27) "in search of whales, sea serpents, \&c." For this fishery she carried patent harpoons that were charged with poison, - prussic acid. In earlier days than that the superstitions of the sea led the captain of the ship, even the bravest of captains, to go to an astrologer for a horoscope that would tell when the stars were in the right position to bring good luck to the venture. The fateful day having come, the sails were spread, but never before, no matter how well the wind served. The horoscope cleared away the terrors, - the imaginary dangers, - but real ones remained that tried the soul. 
I26 The Story of the New England Whaiers

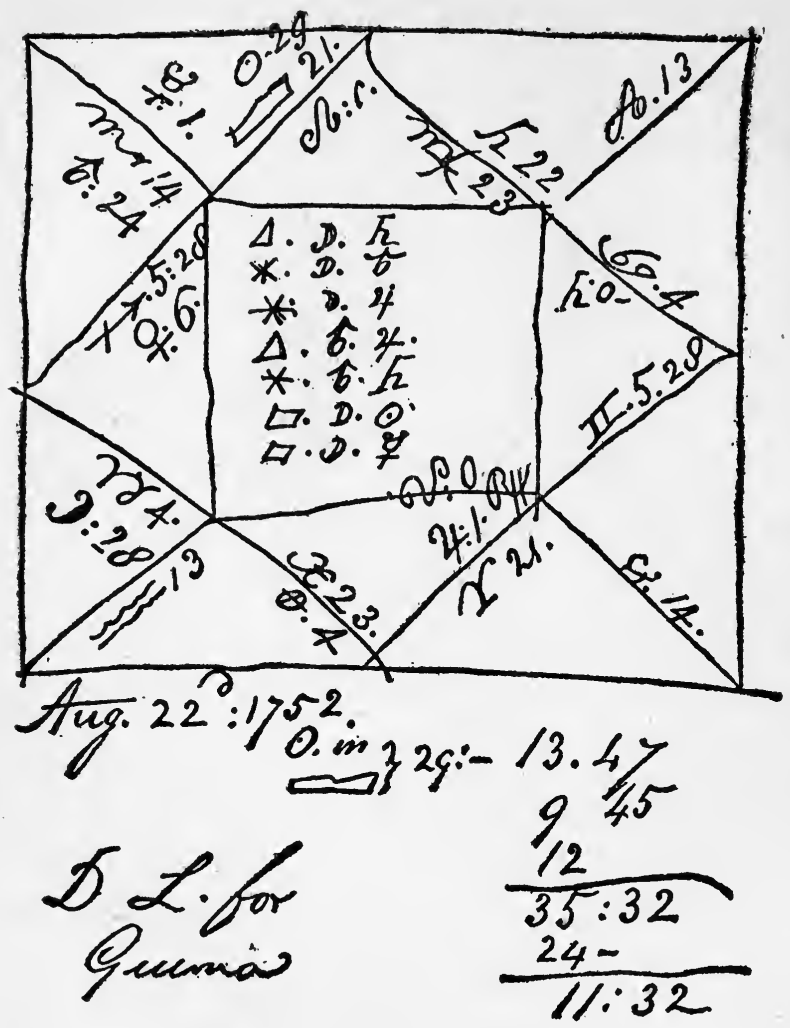

HoRoscope PREPARED FOR CAPTAIN DAVID LINDSAy, OF THE Brigantine “Sanderson," Newport, Rhode Island, $175^{2}$.

The quality of the ships may be inferred from the fact that as late as 1825 the Kingston, Captain Alexander Perry, of Nantucket, was sheathed with leather as a protection from the ravages of the 
teredo. The whirl of the cyclone had not been recognized and ships were hove to with their bows pointing toward the deadly centre of the hurricane. The great plague of the sea, scurvy, was ever before the crews making long voyages. The game sought, especially the sperm whale, was not only a monster of prodigious strength; it was well known to be aggressively vicious, and the boat's crew took their lives in their hands whenever they lowered for the chase.

Nevertheless, of such peculiar fibre was the mind of the whaler that the terrors and dangers which made weaker men tremble were given not a thought, as he made sail for sea. Indeed, if these dangers had any moving influence whatever upon the American whaleman, they did but strengthen his determination to go. With a spirit like that which animated those who searched for the Golden Fleece, or that in the breasts of the Vikings who braved the frozen North, he went forth seeking wonderlands.

Because of this spirit, enough tales of adventure have been recorded in the annals of the whalemen to fill a large volume, some of which shall be given here to illustrate the character of these men. 
i28 The Story of the New England Whalers

In 1827 , while Captain Alexander Macy, of the ship Peruvian, was "in latitude $9 \mathrm{deg}$. $14 \mathrm{~min}$. south and longitude $167 \mathrm{deg}$. $48 \mathrm{~min}$. west," he "discovered land bearing from westsouthwest to south by west, I 2 miles distant, his ship then heading south by east. On the following day he saw two other islands, or prominent parts of the island seen the day before, with valleys intervening, lying to the south and west, the nearest part four miles distant. This island was well wooded," and in a way not pleasing "it was found to be inhabited." Not at all timid were these islanders. "At 3 P.M. a canoe with five natives of large stature and ferocious countenances, well armed with spears and clubs, came under the stern of the Peruvian, and remained there nearly an hour. Soon after many other canoes were seen at the leeward paddling in a direction as though their object was to intercept the ship. The manœuvres of the natives appeared so hostile that Captain Macy made all sail offshore." When the ship's course was changed the whole native fleet came directly in chase, and they were yet bending to their paddles when night came on; but the wind held fair and the ship escaped. 


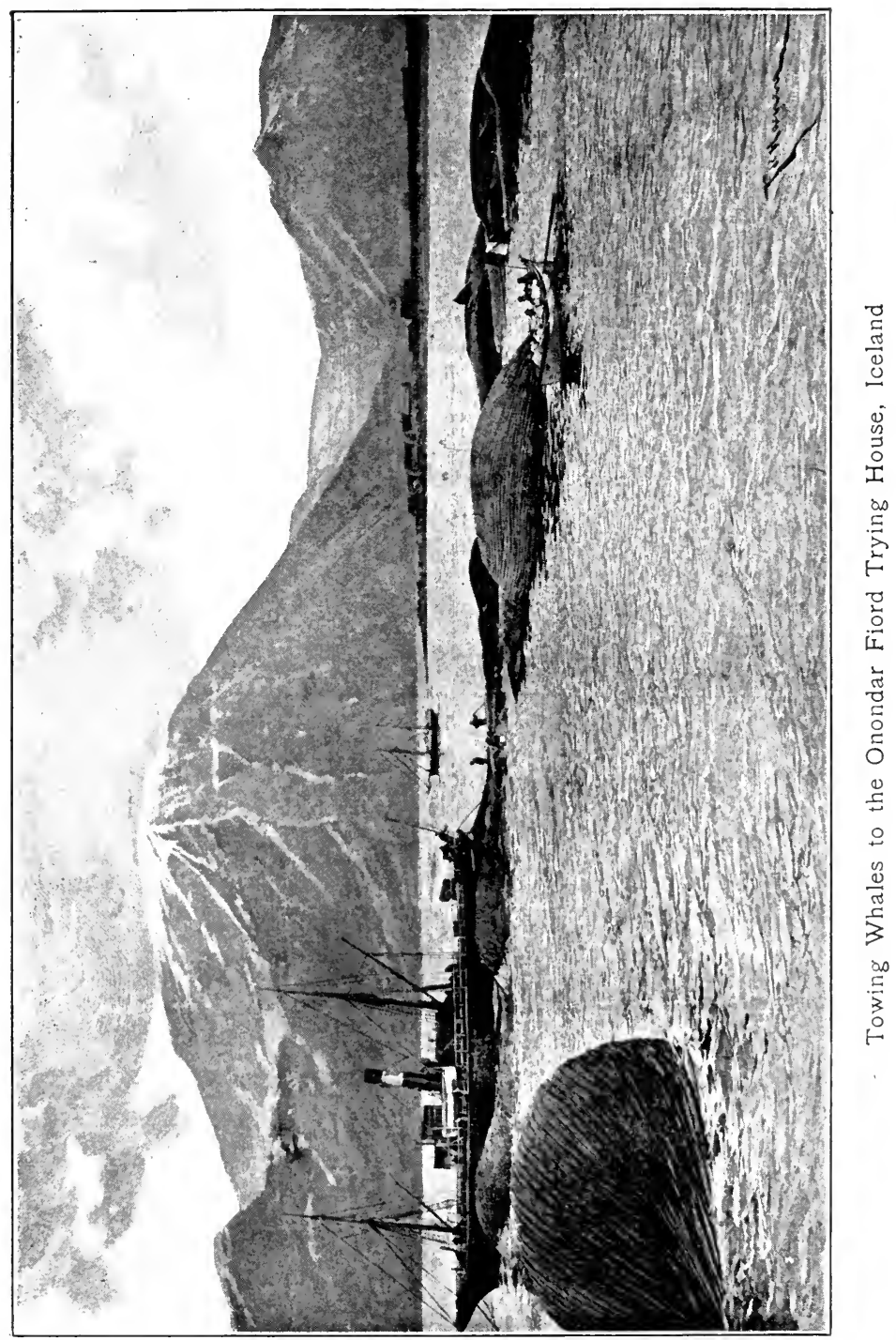



In I819, while the ship Syren was near the Pellew Islands her boats were lowered for whales. The natives, seeing that she was left with but three or four men on board, came off, swarmed over the rail, and drove the ship keepers into the rigging. A recall signal brought the mate's boat alongside, where the mate was able to see the savages dancing in glee over the prize they had captured. Happily for the crew a quantity of tacks had been stowed aloft, and remembering them the mate shouted:

"Break out them carpet tacks and sow'em over the deck."

It was soon done, and the savages, who were wholly unacquainted with such things, were soon dancing to a new tune. With every step they accumulated more tacks in the soles of their feet, and they soon plunged, howling, over the rail and swam ashore.

A dismal tale was that of the Ceno of Nantucket, commanded by Captain Samuel Riddle. In April, 1825, this ship struck on a reef near Turtle Island, one of the Fijis. The crew were received on shore with kindly demonstrations, but a few 
I30 The Story of the New England Whalers

days later another clan of the islanders, on coming to where the sailors were living, were filled with greed for the strange garments worn by the white men; and seeing that no arms were carried by the sailors, massacred all of them but one, who managed to hide in the brush until the murderous clan had gone home.

The story of the Awashonks, Captain Prince Coffin, of Falmouth, Massachusetts, is of similar interest. On October 5, I835, this ship touched at Namorik Island, one of the Marshall group, for refreshments. The natives came off in unusually large numbers; but because they were entirely friendly in their actions, no thought was given to this fact. After some time spent in the usual inspection of the ship, the natives suddenly gathered into a compact body, seized such weapons as were within reach, - especially the "spades" used when cutting in blubber, - and attacked the crew. Captain Coffin was beheaded by a single stroke of a spade. The man at the wheel and the second mate were quickly killed. The third mate, Silas Jones, wrenched a spade from one of the natives, but before he could use it two 
other natives came to the rescue and Jones fled for life down the fore hatch. The other unhurt members of the crew had, meantime, escaped either to the hold or the rigging, leaving the triumphant savages to take charge and head the ship for the shore.

Then the men aloft cut away the running rigging to impede the progress of the ship, while those below, led by Jones, worked their way aft. Finding in the cabin a number of muskets, with ammunition, a fire was opened on the savages, though not with decisive effect, because they gathered in places out of sight.

In trying to get out of range a number of the natives perched themselves above the companionway, which they had closed, and this gave Jones an idea. Placing an open cannister of powder close up under this group, he laid a short train and then, regardless of the danger he incurred, he fired it. The explosion tore off the roof of the cabin and hurled the natives away; whereupon Jones led his men on deck and drove the savages overboard before they could recover from the panic the explosion had created. 
I32 The Story of the New England Whalers

The story of another third mate, Mr. Benjamin Clough, of the Sharon, and his fight with murderous islanders, may very well be told here, because. of the effect which such stories had upon the industry in the earlier days. On October I5, 1842, the whaler Sharon, Captain Norris, of Fairhaven, Massachusetts, put into Ascension Island for wood and water. When ready to proceed on her voyage, eleven of her crew deserted, and being protected by the inhabitants, they succeeded in eluding the officers sent in search. In consequence of this the ship sailed on October 27 with a crew that numbered only seventeen men all told. The captain intended to touch at Bay of Islands or Port Jackson and fill up his crew.

On Sunday, November 6, whales were raised, and two boats were lowered, leaving Captain Norris, a Portuguese boy named Manuel Jose dos Rios, and three natives of the Kingsmill group of islands on board to keep the ship. A fourth islander was in one of the boats. A whale was soon killed by the boats, and as it was not far from the ship it was "waifed," so that the ship might easily run down to it and secure it, while the 
boats went on in pursuit of the "pod" of whales still in sight.

At 3 o'clock in the afternoon, while the mate, a Mr. Smith, was still in pursuit of the whales, he saw that the signal flag of the ship was at half mast, - a call to return to the ship immediately. On arriving near the Sharon the boat's crew saw that the boy was aloft, and as soon as they were within hail he told them that the islanders had killed Captain Norris and were in possession of the ship. To confirm this story one of the natives at that moment leaped upon the rail, entirely naked, where he brandished a cutting spade and dared the crew to come in and attempt to retake the ship. Another of the natives then joined this one, while the third mounted the opposite rail. Along both rails could be seen the spare harpoons and other whaling tools, besides sticks of wood and belaying-pins.

As the boat lay on the water with its crew gazing astounded at what they saw, one of the savages said something in his own language to the fourth native who was in the boat. It is supposed that he invited him to jump over and swim to the ship, 
I34 The Story of the New England Whalers

for the one addressed made a gesture of dissent. Instantly the one on the ship picked up the cook's axe and hurled it at the one in the boat. The force with which the axe was thrown was so great and the aim was so true that the weapon made a clean cut across the back of the shirt of the one in the boat, and it would have killed him had he not dodged it. Then the three natives on the ship united in throwing such missiles as would reach at the boat's crew. No one was hit, but several whalebone belaying-pins struck the rail of the boat and were broken by the force of the blow.

It should be noted that the dead whale had been secured alongside before the natives took the ship, and that the sails had been trimmed to prevent her forging ahead. Fearing that the mutineers would swing the yards until the sails would catch the wind and drive her away from the boats, Mr. Smith ordered the boy to cut the halyards of the upper sails on the mainmast and then go forward on a stay and cut those of the foremast. This was done. Then, the boat of the second mate having come up, a consultation was held to determine what should be done next. For it was evident 
that retaking the ship was to be a more dangerous task than any one there had ever faced. It was first proposed that the two boats should separate and make a dash at both sides of the ship at once. To this Mr. Smith replied that a proper regard for the interest of the owners, as well as for the safety of the men under his command, required him to avoid all personal risk, and he therefore suggested that the crews of the two boats should unite in the boat of the second mate and attack the ship, leaving him alone in his own boat at a safe distance from danger. To this proposition there was immediate dissent, and the men began to talk about pulling away to the nearest land. The second mate dropped out of the consultation by rowing his boat out of talking distance.

In the meantime the mate's boat had drifted rather close to the ship. In the bow of this boat stood a young man named Benjamin Clough. He was only nineteen years old, but by good work had made himself third mate of the ship. Because the crew was short of its complement, he was serving the mate as boat-steerer, or harpooner. On seeing the boat within range of the ship, as 
I36 The Story of the New England Whalers

he supposed, he suddenly picked up the lance that lay at his knee and hurled it at one of the islanders standing on the ship's rail.

As the lance warp was not long enough, the weapon, after stretching the warp, fell into the sea. The native, seeing this, laughed jeeringly, and invited Clough to throw again. To this invitation Clough responded with all his might as soon as he could recover the lance; and again, to the glee of the native, the lance twanged the warp taut and then fell into the sea.

Turning to the mate, Clough said: "Set me a stroke or two nearer, sir;" but the mate, instead of doing so, ordered the men to pull farther away lest the natives begin throwing their ready missiles at the boat again.

Upon this order Clough made no comment,seamen are notably polite to their superior officers, - but after a little he offered to go alone on board the ship by climbing over the bows, if the boy would cut loose the foreroyalstay and let it.drop into the water from the end of the jibboom. It was Clough's intention to climb, with the warp of the lance in his mouth, up the slender stay to 
the end of the jibboom and then, after getting the lance in hand, to charge down the spar and attack the three natives single handed.

To this proposition the mate gave ready consent, but when the boy in the rigging tried to climb up and cut the stay he was unable to do so, for he had been weakened by fright and the fatigue of his previous work.

As the ship was now forging slowly ahead, the two boats pulled to a station off the bows where they lay idle, silently watching the sharks that had been attracted in schools by the carcass of the whale beside the ship. Finally, when night came, Clough once more offered to venture alone upon the ship, and the mate once more consented.

Stripping naked, the young officer took the boat knife in his teeth, slipped over the side of the boat, and began working his way through the water toward the stern of the ship. The water was full of sharks, - two of them swam slowly beside him as he made his way, - but he continued until he was beside the ship's rudder. Up this he clambered and then passed in through the cabin 
138 The Story of the New England Whalers

windows. Though it was perfectly dark in the cabin, Clough found two cutlasses and two muskets, which he loaded, and leaned against the bulkhead beside the stairway leading up to the deck. Then a shot-gun was found, and Clough was loading it when he heard a native coming down the steps. Running to the foot of the steps, Clough picked up a cutlass and plunged it into the body of the native; but as he drew it forth to give another lunge the native grabbed it. A struggle ensued in which the active youth managed to gouge out one of the native's eyes, but the native in the meantime got a hold on the sword and cut Clough's right hand so severely as to disable it. Then the native fell exhausted.

Two of the savages were yet to be dealt with, however, and one of them soon came to the head of the stairs leading down into the cabin. Looking up Clough could see dimly that the native had a cutting spade poised. Hastily picking up a musket from the floor, Clough with his left hand and right forearm got it pointed up the stairs and pulled the trigger. The native fell, dead, down the stairs, but the spade came with him, 
and its edge struck Clough's left arm in the thick muscle above the elbow and cut through to the bone.

Clough now hurried to the cabin windows and called for help, telling the mate that only one of the savages was yet alive, and explaining the nature of the wound that the cutting spade had inflicted. To this appeal, however, the mate replied that as only one shot had been heard he could not believe that more than one savage was dead, and he thought it best not to venture on board as yet. Thereupon Clough tried to staunch the flow of blood from his wounds by applying such clothes as he could find, but was able to accomplish little because his left arm was entirely disabled and his right hand was so badly cut that he could grasp nothing with it. So he lay down on the cabin floor and waited the issue of events.

At the end of half an hour, having heard no sound from the ship, the mate pulled up under the stern and with his crew climbed in through the windows. On striking a light they saw the savage whom Clough had killed, lying at the foot of the steps, while the other was on the transom, 
140 The Story of the New England Whalers

living, but unable to move. One of the men promptly stabbed this savage twice with a boat spade, and the mate fired a musket into the dead body. Then the men went on deck. The remaining savage had jumped into the sea. The dead body of Captain Norris was lying on the quarterdeck, beheaded. The bodies of the two dead savages were thrown into the sea and that of Captain Norris was prepared for burial. During the night the remaining savage returned to the ship and was put in irons. He was delivered, eventually, to the authorities at Sydney, to which port the ship made its way. Clough's wounds healed in due time. When the ship returned to Fairhaven the owners, in spite of his youth, made him its captain, and then laid the keel of a new ship of 600 tons (the Niagara), especially for his use.

Consider the story of Captain Richard Macy, of the Nantucket ship Harvest (Vol. IV, "Naval Affairs," in American State Papers): In 1824, while cruising for sperm whales "in latitude 2 I deg. 2 I min. south and longitude I6I deg. west," as the log read, the lookout cried, "Land 
ho!" The captain bore away for a look near at hand. It was a fair land in the eyes of the sailors, for it was covered with trees and other vegetation, while cocoanut palms stood in ranks along the beach. After a time a harbor was found, and cautiously, with lookouts aloft where they could see under-water reefs when far away, and with men at the braces ready to trim the sails should a change of course suddenly become necessary, and with others heaving the lead to learn the depth of water, the ship reached in and came to anchor.

Then it was seen that the island was not only fertile, but it was inhabited. People, who showed plainly by their actions that they were "timid and much alarmed by the approach of the vessel," appeared. It was manifest that they "had never been visited before, nor had they any knowledge of civilized people,"

Thereupon Captain Macy, though familiar with the tragic stories told of such islanders, lowered a boat and pulled ashore. A little imagination helps one to see the shaggy-bearded captain, clothed in broad-brim hat and a shad- 
142 The Story of the New England Whalers

belly waistcoat, as he stood at the stern, steering that boat toward the shore until he was able to leap to the pebbly beach. How he smiled, and spoke in soothing tones and offered gifts that were beautiful in the eyes of the savages who had gathered, with arms in hands, to meet him, need not be told in detail. But in the account quoted it is noted that after a time "they gathered around him in great numbers. They would not allow him to move or walk a step, but carried him wherever he wished to go," and "paid him every homage they knew how." To the untutored mind of the islanders of the South Sea the whaler was a god.

Of peculiar interest is the brief description of Deception Island, as given by Captain Pendleton, who was a whaler and sealer hailing from New London, Connecticut. On approaching the island he recognized at once that it was an extinct volcano. The sight of such a peak rising out of deep water excited his curiosity and he went sailing alongshore for a further examination. Thus, very unexpectedly, he came to a huge gash or slit in the side of the mountain affording 
"a passage of fourteen fathoms of water" straight into the heart of the peak. Through this narrow passage the venturesome captain steered his ship until she was floating in the centre of the ancient crater, which, to his eyes, "had the appearance of an immense bowl." Who but a whaler would have dared to steer into such a harbor?

Then imagine the feelings of the whalers who were the first white men to land on Fanning's Island. It was "a lagoon island, the land about five feet above the surface of the water." On this low reef the sailors found "the remains of a stone hut about twelve feet square, and in it human bones, stone hatchets, and blackfish teeth with holes drilled through them. Some parts of the island had been cultivated, as appeared by the gardens, fences of stone, \&c., remaining."

The remainder of this story will be readily imagined by those familiar with those waters. Most remarkable navigators were the natives of some parts of the Pacific. With "tracks" charts - made of interlaced and curiously woven sticks, they steered boldly forth, following not only straight courses but crossing currents, and turning 
I44 The Story of the New England Whalers

at a right, or any, other, angle from the original course when points at sea, indicated by their curious charts, had been reached. How they were able to read their woven sticks they could not explain, neither did they know the origin of such curious contrivances, but they understood the things themselves, and they made crooked passages, hundreds of miles in length, with success. Of course they failed sometimes: white men, more learned, did that at times, too; and a crew that had failed had landed on Fanning's Island, built a rude hut; planted gardens, and finally died there alone.

Still more weird was a tale of the Arctic. In August, 1775, Captain Warrens, of the whaler Greenland, while drifting in a calm among a vast herd of icebergs off the Greenland coast, saw a vessel that seemed to be badly dismantled aloft. His "curiosity was so much excited that he immediately leaped into his boat with several seamen and rowed toward her," says an old newspaper account. "On approaching he observed that her hull was miserably weather-beaten and not a soul appeared upon deck. He hailed her crew several 
times, but no answer was returned. An open porthole near the main chains caught his eye, and on looking into it he perceived a man reclining back in a chair with writing materials on a small table before him. The party therefore went upon deck and having removed the hatchway they descended to the cabin. Its inmate retained his former position and seemed to be insensible. He was found to be a corpse, and a green, damp mould covered his cheeks and forehead, and veiled his open eyes. He held a pen in his hand, and a log book lay before him, in which the last entry was yet decipherable. It read:

" 'Nov. 14, 1762. We have now been enclosed in the ice seventeen days. The fire went out yesterday, and our master has been trying ever since to kindle it again without success. His wife died this morning. There is no relief.'

"Captain Warrens and his seamen hurried from the apartment without uttering a word. On entering the principal cabin the first object that attracted their attention was the dead body of a woman reclining on a bed in an attitude of deep interest and attention. Her countenance retained 
I46 The Story of the New England Whalers

the freshness of life. Seated on the floor in one corner of the room was the corpse of an apparently young man holding a steel in one hand and a flint in the other, as if in the act of striking fire upon some tinder that lay beside him.

"In the forward part of the vessel several sailors were found lying dead in their berths and the body of a dog was crouched at the bottom of the gangway stairs."

This ship with her dead crew had been preserved in the Arctic ice for thirteen years. Captain George E. Tyson relates a similar story in his Arctic Experiences.

If space may be allowed for one more tale of adventure, contemplate the landing of Ronald MacDonald on one of the Japanese islands in the days before the awakening of that remarkable people. One ship, the Lady Adams, had disappeared near the Japan coasts (I826), before MacDonald determined to go ashore, and the circumstances made the whalemen believe that she had struck a reef, and that her crew, after reaching shore, had been killed. The ship Lawrence had been wrecked near the coast, and the second mate 
and seven men, after landing, had been treated with great cruelty. One of the number had been tortured to death. The crew of the Lagoda, of New Bedford, that stranded on that coast at about the time of the loss of the Lawrence, were also tortured, and one of these men killed himself to escape further torment. The terrors that awaited all who might be cast away in Japanese waters were well known to the whalemen who sailed to those waters, and yet when the Plymouth, of Sag Harbor, was at work, on a pleasant day, within sight of one of the islands, Ronald MacDonald, one of her crew, asked for and received his discharge. In lieu of his "lay," he took a boat equipped for landing on the island. He carried with him sundry books and utensils likely to be interesting to the natives, and boldly sailed to the beach. When he arrived he was seized, stripped of his possessions, and imprisoned; but because it was apparent that he came desiring only that he might be serviceable to the people, and because he at once began teaching those who guarded him the English language, he was not tortured.

Some time after MacDonald's landing an 
148 The Story of the New England Whalers

American naval expedition, under Commodore Biddle, visited Yeddo, hoping to open trade relations. On the arrival of the naval ships, MacDonald and the survivors of the two wrecked whale ships were warned never to return to the country, and then all were sent off to Commodore Biddle. The stories told by these whalemen, in connection with what Biddle learned, determined the American government to send another expedition (that under Commodore M. C. Perry) to Japan later, with the results well known to all.

From the earliest days of the deep-sea whale fishery the boys of America sat by the hearth and listened, wide-eyed and breathless, to such tales as these whenever a whale ship came to port. They gazed upon the curios, wooden swords that were edged with sharks' teeth, and spears that were pointed with human bones, which the whalemen brought to fortify their stories. And then they read such items as the following, taken from a New York paper printed in April, 1831 :

$$
\text { "Hudson, N.Y., March } 29 .
$$

"Huzza for the Mansfield. - The gallant ship Alexander Mansfield which fitted out at this port last May 
for a two-years' voyage has returned in the short space of nine months and a half with a full cargo having on board 2020 barrels of whale oil, 180 br. sperm oil and 16,000 lbs. whale bone. On Sunday evening she arrived at this place and safely moored at the company's dock amidst the loud huzzas of the citizens, and the firing of cannon.... The Mansfield will be immediately refitted for a second voyage. . . . We have also at the company's docks a beautiful, substantial vessel of about I 800 barrels burthen, called the Wasbington, which is fitted for a whaling voyage. Such is the spirit of the young men in this vicinity that there are already more applications for berths than will be wanted to man her."

In the early days the American whalemen were made up from among the boys who were spurred on to the sea by a love of adventure, and of honor, and of wealth, all in the order named. It was because the whalemen were of the boldest and most enterprising men of the nation that the fishery was spread over unknown seas and to the uttermost parts of the earth within a period of time that was astonishingly brief; and when and how the whalers did this work shall now be told.

In 1775 to have made a voyage to the Falklands was so great a distinction that England's 
150 The Story of the New England Whalers

best-remembered statesman of the period lauded the voyagers in his greatest speech. Captains David Smith and Gamaliel Collins, of Truro, Cape Cod, were the whalers who earned this honor. Their voyage was made in I774. A voyage around the Horn was the next venture forward.

Among the notable merchants of London, England, in 1787 or 1788 , was Samuel Enderby, who had been engaged in the whale fishery, and in trade with America for many years. He was especially interested in whale products, and in the course of the year mentioned he fitted out the ship Amelia, Captain James Shields, a Nantucket man, for a voyage to the fishery on the coast of Brazil. The mate of the ship was Archilaus Hammond, also a Nantucket man. On reaching the Brazil banks it was found that the season was ended. The whales had migrated. To men like Captain Shields, however, seeming misfortunes do but furnish opportunity for distinction. Shields had read the story of the explorations of Captain Cook, R.N., made between $\mathrm{I} 768$ and $\mathrm{I} 779$. Cook had seen many whales on the west coast of 
South America, and when Captain Shields found himself on the Brazil coast too late in the season, he braced his yards on the port tack and stood down to south'ard, bound for Cape Horn.

The luck that follows on enterprise came to Captain Shields. He found the west coast a "greasy" ground, and First Mate Archilaus Hammond was the first white man to drive a lance under the shoulder-blade of a whale in the Pacific Ocean. The Amelia returned to London full of oil in September, I790.

The story told by Shields reached Nantucket and New Bedford before the end of the year, and in I79I six or seven ships sailed from these two ports for the new grounds.

Soon so many ships were haunting these grounds that the whales were killed or driven off. Captain George Swain, 2d, of Nantucket, who sailed thither in $18 \mathrm{I} 7$, declared on his return, two years later, that, although he had saved I388 barrels of sperm oil and 568 of whale oil, no ship would ever again fill with sperm on that coast. Captain George W. Gardner, commanding the Globe, of Nantucket, sailed in 1818 for those grounds, in 
152 The Story of the New England Whalers spite of the gloomy forebodings of Captain Swain. On reaching the grounds, however, he became convinced that $\dot{S} w a i n$ was very nearly right, but with even greater confidence in his luck than that which had animated the captain of the Amelia, he put his helm astarboard and steered westerly into the unknown seas. It is because he steered into unknown waters that the enterprise of Captain Gardner must be considered greater than that of Captain Shields. By this venture Captain Gardner found the "Offshore Grounds." At the end of twenty-six months (whalers always reckoned the length of their voyages by the number of months) Gardner reached home with an interesting, if not a very eventful, story of exploration, and 2090 barrels of sperm oil, worth $\$ 61,555.73$. The Globe was the first ship to carry more than 2000 barrels of sperm oil to Nantucket. Some years later this ship appears again in the annals of the whalers because of a remarkable mutiny among her crew.

While Captain Gardner worked the Offshore Grounds, Captain Joseph Allen, of the Maro, a Nantucket ship, sailed (October 26, 1819) for 
the Pacific. At the Sandwich Islands he found the Rambler, Captain Benjamin Worth, of Nantucket; the Syren, Captain Benjamin Coffin (a Nantucket man), belonging to London (Enderby and Sons); the Cyrus, Captain Elisha Folger, and the Balena, Captain Edmund Gardner, both of New Bedford. While all these ships were lying in port the merchant ship O'Cane, under Captain Winship, a Brighton, Massachusetts, man, came in from Canton. Captain Winship had passed the coasts of the mysterious Japanese islands, and had seen so many whales that he talked with enthusiasm about them to these whalers; and thereupon the whalers made sail for that far-away region. It was a long race, and for a prize that might excite the ambition of any yachtsman. The Syren and the Maro arrived first and together. The Syren saved her first whale on the roth of May; the Maro got her first on June I. Both ships were full to the hatches within three months after reaching the grounds. The Maro returned after a voyage of 29 months with 2425 barrels of sperm oil.

In 1828 four Nantucket ships went to the east 
I54 The Story of the New England Whalers

coast of Africa, where they hunted sperm whales around Zanzibar and the Seychelle Islands. One of them, the Columbus, found her way into the Red Sea. In the years following this venture it was a common thing for the whalers to go to that coast and then sail easterly across the Indian Ocean and among the islands beyond, until they met their neighbors who had sailed around the Horn. St. Paul and Kerguelen Land became stopping places on an easterly route to the Pacific.

Of whaling around New Zealand it is recorded that "large schools of great whales abounded." "Several ships often get into a school of these whales at one time, each vessel taking one or more whales that yield 100 barrels of oil." Tasmania, New Ireland, the Solomon Islands, New Guinea, the Kermadec Islands, New Caledonia, New Georgia, - all these coasts were soon well known to the whalers of the United States. So, too, were the Sooloos, with their Malay pirates.

In 1835 the Ganges, Captain Barzillai T. Folger, of Nantucket, sailed along the northwest coast of North America from latitude 50 to latitude 60 degrees, and found whales of enormous size. 
Some cow whales yielded as high as 250 barrels each. The bone amounted to as much as 1000 pounds for each 100 barrels of oil, and bone was then bringing a price that was worth while.

In 1843 whales were found in abundance on the coast of Kamchatka. The Herkules, Captain Ricketson, and James, Captain J. K. Turner, both of New Bedford, were the first on that coast. The former reached home on April 3, 1845, with 200 of sperm, I900 of whale oil, and I2,000 pounds of bone, while the other arrived on June 9, I845, with 270 sperm, I600 whale oil, and 20,000 pounds of bone.

It was in those days that the bowhead, a whale so called because of the shape of its head (it was a "bone" whale), was first seen in the North Pacific. Just which one of three claimants had the honor of this discovery is now past finding out. Captain George A. Coville, of New Bedford, having entered the Okhotsk Sea on a venture, killed there a whale which he supposed would yield about 70 barrels. On trying out the blubber it yielded 150. The whaler Huntsville was in the region about that time and 
156 The Story of the New England Whalers claimed the honor of killing one of these surprising whales before Coville killed his. A French ship named the $A$ sia, commanded by an American, also claimed the honor. Disputes aside, it is certain that many whalemen soon found large profit on these grounds, for the whales were so tame and easily killed that saving them was like slaughtering pigs in the barnyard at home.

On October 22, 1847, the little bark Superior (275 tons only) cleared out from Sag Harbor for the far-away Asiatic grounds. On arriving, it occurred to Captain Royce, commanding the bark, that the Arctic Gateway, namely, Bering's Strait, was but a little way off to the north, and that it was invitingly open. Such an invitation was irresistible, and squaring away he entered. At the end of 19 months from the day he sailed, a marvellously short time, considering the distance, the Superior sailed back into Sag Harbor with all flags flying. She was loaded to the hatch combings with oil, and carried bone wherever it could be stowed, -80 barrels of sperm, 2400 of whale oil, and 20,000 pounds of bone, the whole worth $\$ 33,945 \cdot 30$. 
"A few years since," says the North American Review (January, 1834), "two Russian discovery ships came in sight of a group of cold, inhospitable islands in the Antarctic Ocean. The commander imagined himself a discoverer, and doubtless was prepared, with drawn sword and with the flag of his sovereign flying over his head, to take possession in the name of his Czar. At this time he was becalmed in a dense fog. Judge of his surprise, when the fog cleared away, to see a little sloop from Connecticut, as quietly riding between his ships as if lying on the waters of Long Island Sound. He learned from the captain that the islands were already well known, and that the sloop had just returned from exploring the shores of a new land at the south; upon which the Russian gave vent to an expression too harsh to be repeated, but sufficiently significant of his opinion of American enterprise."

The day of the explorers was the Golden Era of the whalers, and of all American. seamen. "Often adventures which Vancouver dedicates three chapters to, these men accounted unworthy 
158 The Story of the New England Whalers of being set down in the ship's common log." (Moby Dick.) A list of more than four hundred islands which were discovered in the Pacific by American whalers is found in the public document quoted above. But "whale, strongtimbered craft and swift clipper boat are gone. ... We have lost our natural place upon the seas. . . . No one can contemplate these achievements and this decay without sadness." (Weeden.) 


\section{VIII}

\section{WHALES AS THE WHALERS KNEW THEM}

$\mathrm{Oh}$, the rare old whale, 'mid storm and gale, In his ocean home will be,

A giant in might where might is right, And king of the boundless sea.

- Whale song quoted in Moby Dick.

T THEN Owen Chase, mate of the Nantucket whale ship Essex that was sunk by a whale in 1820 , finally reached home and related his experiences, he had this to say about the whale that attacked the ship:

"Every fact seemed to warrant me in concluding that it was anything but chance which directed his operations; he made two attacks upon the ship at short interval between them, both of which, according to their direction, were calculated to do us the most injury, by being made ahead and thereby combining the speed 
160 The Story of the New England Whalers

of two objects for the shock; to effect which the exact manœuvres which he made were necessary. His aspect was most horrible and such as indicated resentment and fury. He came directly from the school, which we had just before entered, and in which we had struck three of his companions, as if fired with revenge for their sufferings. ... At all events, the whole circumstances taken together, all happening before my own eyes," produced "at the time impressions in my mind, of decided, calculating mischief."

The mate's thoughts, as he left the ship, are expressed as follows:

"The dark ocean and swelling waters were nothing; the fears of being swallowed up by some dreadful tempest or dashed upon hidden rocks ... seemed scarcely entitled to a moment's thought; the dismal-looking wreck and the horrid aspect of the whale wholly engrossed my reflections."

Many pictures of the whale have been printed. Some were the dreams of poets. Others were the tabulated measurements made by scientists. 


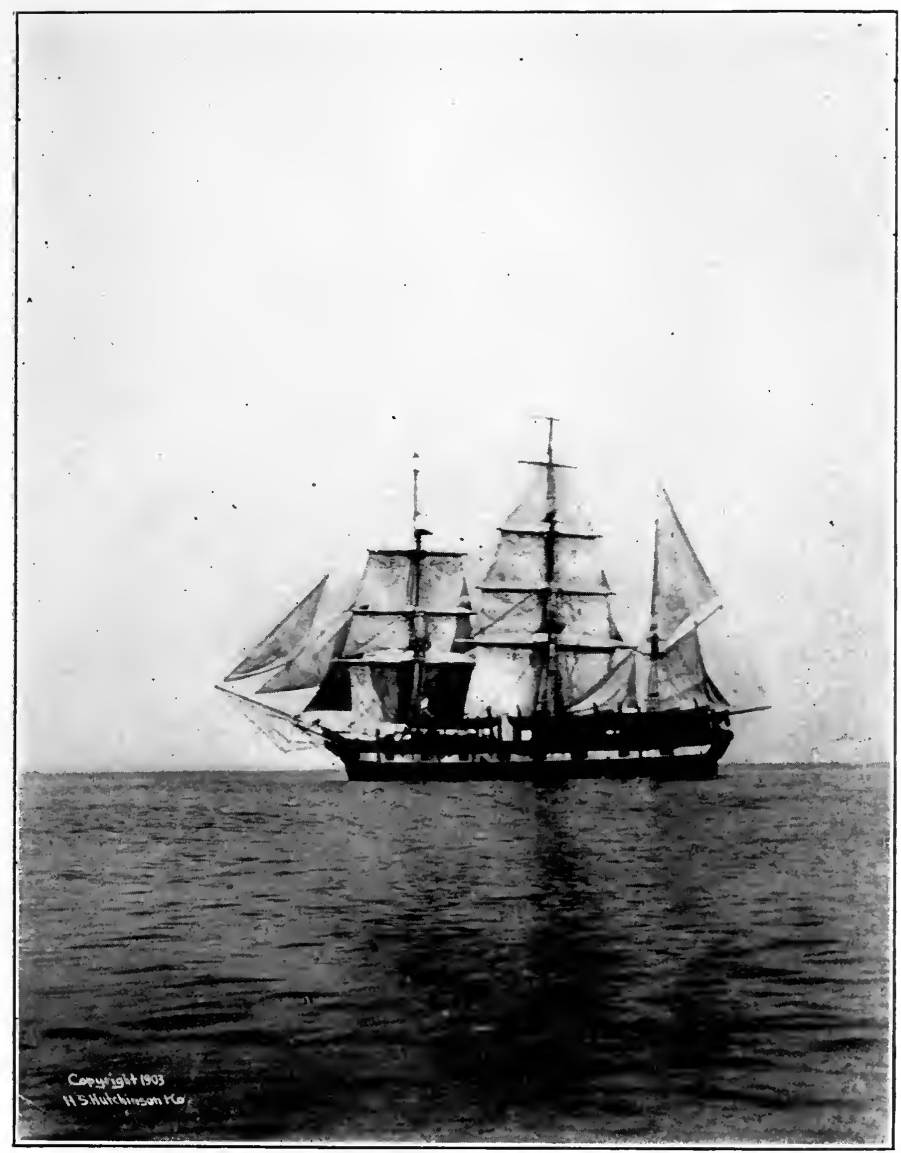

Off for a Two Years' Cruise 

Whales as the Whalers Knew Them I6I

Others still were the life scenes portrayed by the men who hunted whales wherever whales were to be found. In any story of American whaling all of these pictures seem to be of interest; but if it were necessary to make a choice among them, one would naturally select first of all those made by men who received their impressions while afloat, gunwale to fluke, beside the monsters to be described. When a man who has worked his way from the berth of an apprentice to that of chief mate of a whale ship, as Chase had, tells what he has seen of whales, his words are worth attention.

Nevertheless, it seems best to begin here with what might be called the scientist's point of view. As the reader learned long ago, the whales are not fish, but mammals, - animals that suckle their young. Unlike the fish, they have warm blood and lungs, and must come to the surface of the water to inhale fresh air at intervals under penalty of death by drowning. The fins, one on each side near the body, which help to make the whale look like a fish, have bones within that are not very different in location and number 


\section{The Story of the New England Whalers}

from the bones of a human arm, and it is a matter of common knowledge that the mother whale clasps her young to her breast by means of a fin much as a human mother holds her babe.

It is believed that in some long-ago period of the world's development the whales lived alongshore, part of the time on land and part of the time in the sea. How they were driven from the land to permanent homes in the sea is a matter of inference. Very likely the food supplies in the ancient seas were abundant. At the same time some huge reptile sought them for food when they were out on the land. A peculiar habit of the modern whale strengthens the belief that they once had enemies on the shore; when alarmed, now, they sometimes rise up perpendicularly with their heads well out of water, - they stand up like a beaver, so to speak, to scan the sea, and when in that position they revolve slowly around until they have looked in all directions with both eyes.

While in Madagascar waters, Frank Bullen (Cruise of the Cacbelot) saw a school of sperm whales playing around the ship, the crew being 
Whales as the Whalers Knew Them 163

too busy with blubber already taken to lower in pursuit. Of one thing they did, he says:

"As if instigated by one common impulse they all elevated their massive heads above the sea and remained for some time in that position, solemnly bobbing up and down amid the glittering wavelets like moveable boulders of black rock. Then all suddenly reversed themselves and, elevating their broad flukes in the air, commenced to beat them slowly and rhythmically upon the water, like so many machines."

It is supposed that whales may have been animals not wholly unlike the flat-tailed beaver; that, like beavers, they sat up or rose up on their haunches to look around when danger seemed to impend; also when they saw anything that excited their curiosity; and, finally, that in the course of the evolution of the race the hind legs were eliminated and the tail was developed into the form now seen.

Of hind legs the whales have not a trace. From their lungs to the tips of their tails, whales are very good fish, and yet the whales differ from all fish in the position of their flukes. 
I64 The Story of the New England Whalers

"A whale is a fish with a tail that lies on the water as flat as a pancake," said an old whaler to the writer, "and every fish, big or little, with that kind of a tail, is whale." The tails of fish are in a vertical plane.

Of the many kinds of whales described in the works of scientists two are of special interest here. One is called the right whale, and the other the sperm whale. Cachelot is another name applied to the sperm. If seen side by side at sea, they are at first glance very much alike, for each looks like a long, smooth, black rock, or say a monster log of black wood (albinos have been seen), over which the waves run freely, or break in masses of foam and spray. When they raise their heads out of the water, however, differences are at once seen. The head of the sperm whale is as blunt and flat as if the animal had, during untold ages, been in the habit of striking its head on the bottom every time it dove for food. The lower jaw is long and slender. The head of the right whale is blunt, but well rounded instead of flat on the end. It is rather flat on top and the lower jaw or chin 
Whales as the Whalers Knew Them 165 is thicker than the top of its head. As each whale expels the air held in its lungs while under water, a single vapory jet is spurted up and forward at an angle of 45 degrees from the forward point of the sperm whale's head; the right whale throws up two jets from the back part of its head, the spiracles, as the breathing holes are called, being located nearly above the angle of its jaws.

If the mouths of the two kinds of whales be examined, most remarkable differences are found. A single row of teeth is found on each side of the long, narrow, lower jaw of the sperm whale, the total number being from forty to fifty-six in an adult. The largest of the teeth are nine or ten inches long, and these weigh about a pound and a half each. They are all pointed, and they are placed far apart. There are no teeth in the upper jaw. A hole is found in the upper jaw opposite each tooth, and when the mouth is shut the teeth set into these holes. The teeth are not grinders; they merely serve to hold and break apart the squirming food of these monsters, which is to be described farther on.

The right whale has no teeth. Affixed to its 
I66 The Story of the New England Whalers

upper jaw are slabs of a hornlike substance called whalebone. In the largest whale, slabs more than twelve feet long are found. Captain David Gray, of Peterhead, Scotland, a noted authority, counted 286 slabs of bone on one side of the mouth of a whale he killed and 289 on the other side. There seems to be no regularity in the number of slabs; other whalers who have counted them find a different number with every count. When the whale's mouth is closed these slabs are slanted back, lying like piles of thin boards between the upper and lower jaws. When the mouth is opened, the lower ends of the slabs spring forward until they hang almost, but not quite, perpendicular along the sides of the mouth, where they form a screen. The inner edge of each slab is frayed and split into many long hairs and these cover over and fill in the spaces between the solid parts of the slabs, thus converting a coarse screen into a fine sieve. The lower lip supports and holds in place the lower edge of this sieve, while the upper lip is drawn up in a horrible grin, that fully displays the huge slabs. 
Whales as the Whalers Knew Them ${ }_{167}$

The food of the right whale consists of a variety of small animals that float in wide masses on the sea, - crustaceans "not larger than a common house fly," called "brit" by the whalers. When the whale wishes to feed, it swims to and fro with its mouth open through the floating brit. Water and brit together float into and through the unobstructed forward part of the mouth. The water then flows out through the whalebone sieves on each side of the mouth, while the brit is caught by the sieves.

"The usual way in which a whale feeds," wrote Captain Gray, "is to choose a spot where the food is plentiful and swim backward and forward for two or three hundred yards with the nose just under water. They invariably swim from one side of the beat back again to where they started from, with their mouths open. Then they close their jaws and swallow the food caught." After the mouth is closed the tongue is raised and the remaining water is forced out, leaving the crustaceans caught on the screen. "They often go with the point of the nose so near the surface that we can see the water running 
I68 The Story of the New England Whalers

over it just as it does over a stone in a shallow stream. . . Their course below the water can often be traced by their eddy. This is caused by the movement of the tail. . . . They turn around before coming to the surface to blow, and lie for a short time to lick the food off their bone before going away for another mouthful."

Whales vary much in size even when adult. According to Whales and Porpoises, by George Brown Goode, Assistant Secretary of the Smithsonian Institution (p. 9), “The largest sperm males measure from 80 to 84 feet in length, the head making up about one-third of the whole. The youngest sperm whale on record is one measuring sixteen feet, taken near New Bedford in 1842 ; its weight was 3050 pounds." The female sperm is small, being from one-fifth to one-fourth the size of the male. The record sperm whale reported at New Bedford was captured by Captain Owen H. Tilton. It produced I54 barrels of oil. Captain C. Allen saved one that produced 150 barrels. The usual product is from forty to fifty barrels, but many are taken that yield from 80 to 100 barrels. The length of a common sperm whale is from forty to fifty feet. 
Whales as the Whalers Knew Them 169

The largest of the sperm whales - eightyfour feet long - measure thirty-five or thirtysix feet in girth at the thickest part, which is at the neck, if a whale may be said to have a neck. The body is deeper than it is broad at all points from the head to the "small" (namely, where the body joins the flukes), and at the small it is round. The height (or depth) of the largest sperm whale "at the forehead is eleven feet and its width nine or ten feet," according to Davis, author of Nimrod of the Sea. As one of these monsters lies on the surface with its head out of water its crown, or nose angle, is as high above the surface as the roof of a one-story house. When the animal is standing up with head out of water scanning the horizon, the top of its head may be not far from thirty feet up in the air, or say as high as the roof of a three-story house. It would not seem so high to a spectator on a ship, because the immense expanse of the sea dwarfs everything afloat. But if seen from a whale boat alongside, it would seem much larger, especially to a frightened landsman.

The tails of all whales are divided into two 
I70 The Story of the New England Whalers

flukes. The length of the largest, as measured fore and aft, is from six to eight feet, while the breadth across both is from twelve to fifteen feet. These figures have a special interest when it is known that many a venturesome whaler has driven his boat in under the rising flukes, to a place where nearly a hundred square feet of that most deadly weapon rose above him.

It is said that the right whale received its name through the custom of the early European whalers in speaking of it as the right kind to capture. The sperm whales were not pursued in the early days, apparently. Whales that produced plenty of oil and bone were the "right" whales to capture. In time, however, it was observed that there were several kinds of oil-and-bone whales. The early whaler explorers who went hunting along the polar ice found one that they named bowhead, from the shape of the head as seen above water. Another whale was named humpback because of the shape of its back. It was noted that the humpback had folds of skin under its chin, and that its fins were of extraordinary length. An examination of the records of 
the fishery for the oil-and-bone whales shows that the whalers did not always distinguish between the varieties. A table in Whales and Porpoises says that Captain Devot, of New Bedford, killed a right whale off Kadiak that yielded 290 barrels of oil. Captain Wood took one that gave 280 barrels, while Captain Winston got one of 270 barrels. The average yield of whales taken on the North Pacific ground ( $\mathcal{T}$ be Whale Fishery, p. I7) is or was "about 125 barrels each." It is the bowhead whale that raises the average yield to this figure, and it is not unlikely that the enormous yields recorded above were from this variety of the right whale. It is interesting to note that while bowheads yield so much oil, they are never more than sixtyfive feet long. The large male right whales are from fifty-two to fifty-three feet long, while the females are from fifty-four to fifty-seven feet long.

The humpback whale is still smaller. The record yield from one of these was I 45 barrels, secured in 1848 , from a humpback killed off Monterey, California. 
172 The Story of the New England Whalers

While the records do not, for obvious reasons, contain the weights of adult whales, fair estimates have been made. Scoresby calculated the size or displacement of an Arctic whale at 81.5 cubic feet, which would give a weight of about II4 tons. He estimated the weight of an ordinary large right whale at seventy tons.

The horse-power exerted by a finback whale in propelling itself through the water was estimated by Sir William Turner, Professor of Anatomy at the University of Edinburgh, assisted by Mr. John Henderson, a Glasgow shipbuilder, in I886. A whale of this kind was stranded at Longniddry. It was 80 feet long, its estimated weight was 74 tons, and the tail was from 18 to 20 feet wide across the broadest parts. To attain a speed of twelve miles an hour, for whales of this kind often swim at that rate, required the exercise of "a propelling force of I45 horsepower." (Scientific American, March 5, r887.)

The records show that finbacks 120 feet long have been killed. Sulphur-bottom whales (so called because of the color of the under parts) reach a length of IIo feet, according to $T$ be 
Whale Fishery., Dr. James H. Weeks, of Stonington, Connecticut, in a series of articles on A Whaleship's History, printed in the Westerly, Rhode Island, Sun, in 1900, in speaking of the sulphur-bottom whale, says:

"Captain Frederick Smith has a section of a backbone taken from this species in his yard [on Elm, corner of Cutler Street, Stonington], [that] was taken from a whale which, on the beach, measured I50 feet."

Turning again to the life habits of the whales, consider how they breathe. The sperm whale comes to the surface, raises its head, and for three seconds expels the foul air from its lungs. The exhaled air is full of moisture, and when this vapor settles on human skin it is so acrid as to create pain. Fresh air is drawn in so rapidly "that hardly an instant is required." The exhalation and inspiration, or the "blowings," are repeated sixty or seventy times at a rising, the whole time devoted thus to renewing the air of the lungs and aërating the blood being twelve minutes on the average. Then the whale dips its head under water, raișes its tail until 
I74 The Story of the New England Whalers

it stands perpendicularly on its head, and drops swiftly down. It remains out 'of sight, presumably searching or waiting for food, for an hour or an hour and a quarter.

The bowhead whale, found along the Arctic ice, when undisturbed, comes to the surface, "spouts" from six to nine times, dips down and pursues its food for fifteen or twenty minutes, and then comes up again.

"They will go on in this way feeding for an hour or more," said Captain Gray, already quoted. "After that they will disappear under the nearest ice and sleep there until they come out for exercise or for another meal. Unlike other warm-blooded animals they do not require to breathe through their nostrils while asleep, and they do not do so. Whales can sleep as well under water as they do upon the surface, as I have often seen them disappear under solid ice and remain there for many hours at a time. Sometimes they also fall asleep with their heads down and only their tails out of water."

It is apparent from this that when sleeping these whales do not inhale any air. Captain Gray continues : 
Whales as the Whalers Knew Them 175

"Like all the inhabitants of the sea, whales are affected by the tides, being most numerous at the full and change of the moon, beginning to appear three days before and disappearing entirely three days after the change. Often this will go on for months with the utmost regularity, unless some great change in the ice takes place. No doubt whales are seen and often taken during any time of the tides; but if a herd is hunted systematically, and they are attached to a particular feeding bank, this is their usual habit. Neither can this peculiarity in their habits be easily accounted for; their food is as abundant during the neap as it is in the spring tides."

Davis, previously quoted, notes a similar peculiarity in connection with the sperm whale fishery of the Pacific. He says:

"The length of time that a whale can remain under the surface is probably much greater than has hitherto been allowed. Sometimes, notably during the full of the moon, the whales abound over the feeding ground, and many are taken. But the busy season is followed by a period of 
I76 The Story of the New England Whalers

two weeks or more during which none will be visible. Vessels will be spoken from all points of the compass, and to the question, 'Have you seen any whales?' the answer will be, 'Not for a week or ten days.' The busy and dull seasons alternate uniformly over an area of 600 miles north and south by 900 miles east and west. Bull whales often appear as though they have been reposing on a muddy bottom, and off the coast of New Zealand they have been seen with such barnacles on their lower jaws as are found on a ship's bottom."

The brief length of time that whales are away from their feeding grounds, as described by Gray and Davis, forbids the idea that they migrate, during that interval, to other feeding grounds; for there are no other grounds within reach. The only explanation of their disappearance that seems reasonable is found in the hibernating habit.

In connection with this idea of whale hibernation it is interesting to note a peculiarity of the circulation of the blood in the whale. The amount of blood in an adult is, of course, enormous. 
The main artery leading from the heart is a foot in diameter. The lungs are of corresponding capacity. When the blood flows purified from the lungs it does not go directly into the circulation, as in other animals, but into a cellular reservoir (called an arterial plexus, by one writer), and there it is stored uncontaminated, to be drawn into circulation as needed. It is agreed among scientific writers who have described the whale that in this storage reservoir (so to speak) of aërated blood is found the explanation of the ability of the whale to remain under water, even when wounded, for more than an hour. The bottle-nose whale (a small member of the sperm family) remains under for more than two hours, and then comes to the surface with enough speed to carry it through the air in a graceful curve. Now, in connection with these facts about the whale, consider the condition of the woodchuck, a land animal that has no storage reservoir of aërated blood. As the writer has observed, woodchucks while hibernating have been known to live when their dens were entirely under water for a period of at least forty-eight hours. This 
I78 The Story of the New England Whalers

long submergence had no injurious effect upon them so far as any one could see, for they were as lively as ever when revived by the return of spring. If a woodchuck, having no reserve of aërated blood, can endure submergence for such a length of time, it is not unreasonable to suppose that whales, with their enormous reserves of aërated blood, might sleep under water for periods at least as long as those during which they disappear from their feeding grounds.

Most remarkable, and perhaps unexplained, is the ability of the whales of a school to communicate with each other. In $T$ be Whale Fishery (p. 266) is the following:

"It is worthy of remark that as soon as a whale is harpooned the news is telegraphed through some invisible agency to others of the same species, though at a great distance; a general stampede ensues, and with noses in the air they all rush to windward."

Bennett, the author of $A$ Whaling Voyage Around the Globe, says in regard to this habit: "It is a confirmed fact, and one often noticed by southern whalers, that upon a cachelot being 
struck from a boat others many miles distant from the spot will almost instantaneously express by their action an apparent consciousness of what has occurred, or at least of some untoward event, and either make off in alarm, or come down to the assistance of their injured companion. But without attributing to the cachelot an extraordinary acuteness of sight or hearing, or any more mysterious sensibility, we may perhaps find that the violent agitations of the sea produced by the plunges of the harpooned whale, and the more rapid and distinct conveyance of sound in water than in air, are sufficient to account for the above phenomenon."

Other observers have declared that distant whales have been alarmed when the stricken whale made no excessive noise or unusual disturbance in the water, and that the alarm was conveyed to windward as well as to leeward. Thus Davis says:

"It is commonly conceded that whales have a mysterious power of communicating with each other, and instances are mentioned which, if trustworthy, afford the strongest proof possible. 
180 The Story of the New England Whalers

Stationed at the mastheads of their vessels captains have observed that when their boats were attacking a whale to leeward a school several miles to windward, and out of sight of the combatants, would show signs of alarm and retreat the moment the first blow of the harpoon was struck. Sound was not the means of communication, as the distance was too great, and furthermore it is a well ascertained fact that whales only signal by sound in the practice of 'lob-tailing.' In 'lob-tailing' the whale rises perpendicularly in the water with its head downward. Thus poised it will swing from side to side sweeping a radius of thirty feet with awful violence. The concussions of its tail with the water may be heard for many miles, while the sea is a mass of foam, and the air is filled with spray. The practice is supposed to be intended for amusement, but it is also a tocsin."

"The instant one is attacked every whale for miles around springs up, shoots his head out of water and listens," says another observer. In connection with this unexplained method of communication one should remember the habit 
Whales as the Whalers Knew Them I8I

of the whale, brought down from the time when it lived alongshore, of rising up with head far above the water, as a woodchuck rises on the land to look for danger.

It is further to be noted that undisturbed schools, while spread out and while playing over several square miles of the seas, will suddenly, and as if answering a signal, all throw their tails into the air and instantly and together disappear under water. No trained soldiers ever stepped together with greater precision than is shown by schools of whales in this evolution.

Do whales have vocal cords? Can they sing and roar? Manifestly the men who know the whales best think so.

Herbert L. Aldrich, author of Arctic Alaska and Siberia, in describing his experiences in an Arctic whaler, says :

"One of the most interesting of the [gamming] yarns was that about the singing whales. When I first heard it I took it for a joke, intended for me to bite at. But one day there was a rehearsing of experiences and I found that the ship masters really believed that whales do sing. Captain 
182 The Story of the New England Whalers

Kelley, of the brig Eliza, was the first to discover this singing, but he was laughed at for it. In I882 several ships lay at anchor under Indian Point. As usual the masters got together and in the midst of their conversation Captain Kelley broke in: 'There's a bowhead!' Everybody laughed about 'Kelley's band,' but he insisted that whales were near by and he was going to give chase. One master suggested that it was the copper on the ship, another that it was seals, another that it was the ice, and so on. But when Captain Kelley took up anchor and set sail every ship followed him. One whale was caught. Soon more singing was heard. The result was the capture of several whales. After having attention thus forcibly called to the singing it was not long before the masters were on the lookout for it. It is inferred that it is a sort of call or signal for whales, when making a passage through Bering Sea, to notify each other that they are bound north, and perhaps that the straits are clear of ice.

"While Captain Wm. H. Kelley was right whaling in the Japan Sea in I88I he put his 
Whales as the Whalers Knew Them I83

ear to the line and heard the whale that he had struck give a deep, heavy, agonizing groan, like that of a person in pain. It had been known for a long time that humpback whales, black fish, devil fish and other species of whales sing, and that walruses and seals bark under water, and it is believed that all animals having lungs and living in the water, as these do, have their own peculiar cry, or as whalemen express it, 'sing.' Whenever a whale is struck by a harpoon it is noticed from the masthead that every whale in sight is 'gallied,' that is, frightened. Usually they disappear, but occasionally they simply jump, then settle back quietly to feeding or whatever they may be doing. It is particularly true that sperm whales take fright when one of their number is struck. No reason has ever been assigned for this sudden signal of danger except this 'singing' theory. It is believed that when a whale is struck its cry of pain is heard by every other whale in sight from aloft.

"In January, 1887, one of the Eliza's boats struck a sperm whale and instantly the whole school, which was three miles or more off, started 
I84 The Story of the New England Whalers

for their wounded companion, and circling about it huddled as if to ask, 'What's the matter?' With bowhead whales the cry is something like the hoo-oo-oo of the hoot owl, although longer drawn out and more of a humming sound than a hoot. Beginning on $\mathrm{F}$ the tone may rise to $\mathrm{G}$, $\mathrm{A}, \mathrm{B}$, and sometimes to $\mathrm{C}$ before slanting back to $\mathrm{F}$ again. With the humpback whale the tone is much finer, often sounding something like the E string of a violin."

On page 212 of Goode's The Whale Fishery is the following:

"Sperm whales travel the seas in great herds, from one hundred to three hundred, and they are said to acknowledge a leader, who swims in advance and gives the signal of combat or flight by uttering a peculiar roar."

In Notes on the Challenger by H. N. Mosely, it is said regarding the "singing" of the southern "finners," "The expiratory sound is very loud when heard close by, and is a sort of deep bass snort, extremely long, loud and somewhat prolonged; it might even be compared to the sound produced by the rushing of steam at high pressure from a large pipe." 
Whales as the Whalers Knew Them 185

A description of the eyes and ears of the whales should prove interesting in connection with what has been written about the whale's powers of communication. While the eye socket in the skeleton of a whale might lead one to suppose that the eye is of a size somewhat in proportion to the bulk of the animal, this organ is in fact small. Herman Melville, in Moby Dick, compares the eyes of a full-grown sperm whale to those of a colt. Moby Dick is a novel, but Melville's descriptions of whales and whaling are accepted at New Bedford. The eyes of all whales are located far aft and well down near the angle of the jaw. The whale, therefore, has an extremely limited field of vision. Melville says that each eye covers no more than "some thirty degrees of vision in advance of the straight sideline of sight; and about thirty more behind it." That the whale's eyes unite to portray a single field of view upon the brain, as the eyes of a man do, is of course impossible. It is reasonable to suppose that the whale ordinarily sees and comprehends two distinct fields of vision. When he raises his head perpendicularly out of water 
I86 The Story of the New England Whalers

and revolves slowly around to gaze in all directions, he is confirming his previous impressions as well as exploring new fields. When attacked without previous warning the unfortunate animal is, of course, too badly startled to take a survey of the whole face of the sea, but it may - it frequently does, in fact - see an enemy in each of its fields of vision, while at times more than one is seen in each. It is thus that the whale is "gallied," according to Melville, who says:

"It may be an idle whim, but it has always seemed to me that the extraordinary vacillations of movement displayed by some whales when beset by three or four boats; the timidity and liability to queer frights so common to such whales - I think all this indirectly proceeds from the helpless perplexity of vision volition in which their divided and diametrically opposite powers of vision must involve them."

Still smaller than the eye is the ear of a whale. The external opening of the ear in the sperm is near and behind the eye, "and into the hole itself you can hardly insert a quill, so wondrously minute is it." The right whale ear is not only 
Whales as the Whalers Knew Them 187

small but it has no external opening, being covered with a membrane.

To go on with the mysterious and unexplained characteristics of whales:

"Another peculiarity of the whale," says Davis, " is the 'glip.' When the sperm whale is alarmed or alert against pursuit, it emits, on going down for a run beneath the surface, a portion of oil or its equivalent, which, for a considerable period of time, causes a smooth, bright surface upon the water. This is termed the glip or wake. The mystery of the glip is in a real or supposed communication between this smooth spot and the whale making it. Should the boatheader incautiously pull his boat into this glip or cross the line between the whale and his glip, the effect will be to gallie the animal."

James Templeman Brown, who contributed a large portion of the matter found in Goode's The Whale Fishery, after quoting the above from Davis, says :

"This is maintained and substantiated by whalemen generally." He also says (p. 26r) that the right whale possesses a similar power: 
I88 The Story of the New England Whalers

"An officer of a boat never follows the wake of a right whale, for the moment the boat strikes the 'suds' it is maintained that the whale is immediately made acquainted with the fact through some unknown agency and will be gallied without fail, and soon widen the distance between itself and the crew."

Frank Bullen (Cruise of the Cacbelot), in describing the pursuit of the first whale (a sperm) struck by the boat in which he pulled, says that as they approached the whale the boat was suddenly stopped and allowed to drift.

"Now what's the matter, I thought, when to my amazement the chief, addressing me, said: 'Wonder why we've hauled up, don't ye ?' 'Yes, sir, I do,' said I. 'Wall,' said he, 'the fish hev sounded, and ef we run over 'em we've seen the last ov 'em.'"

Curiously interesting is the ability of whales to sink swiftly at will. When the whalers approach a whale they drive their boat in forward of the flukes until it lies "wood to blackskin," - in contact, or nearly so. As the boat is about to strike the whale the harpooner throws his 


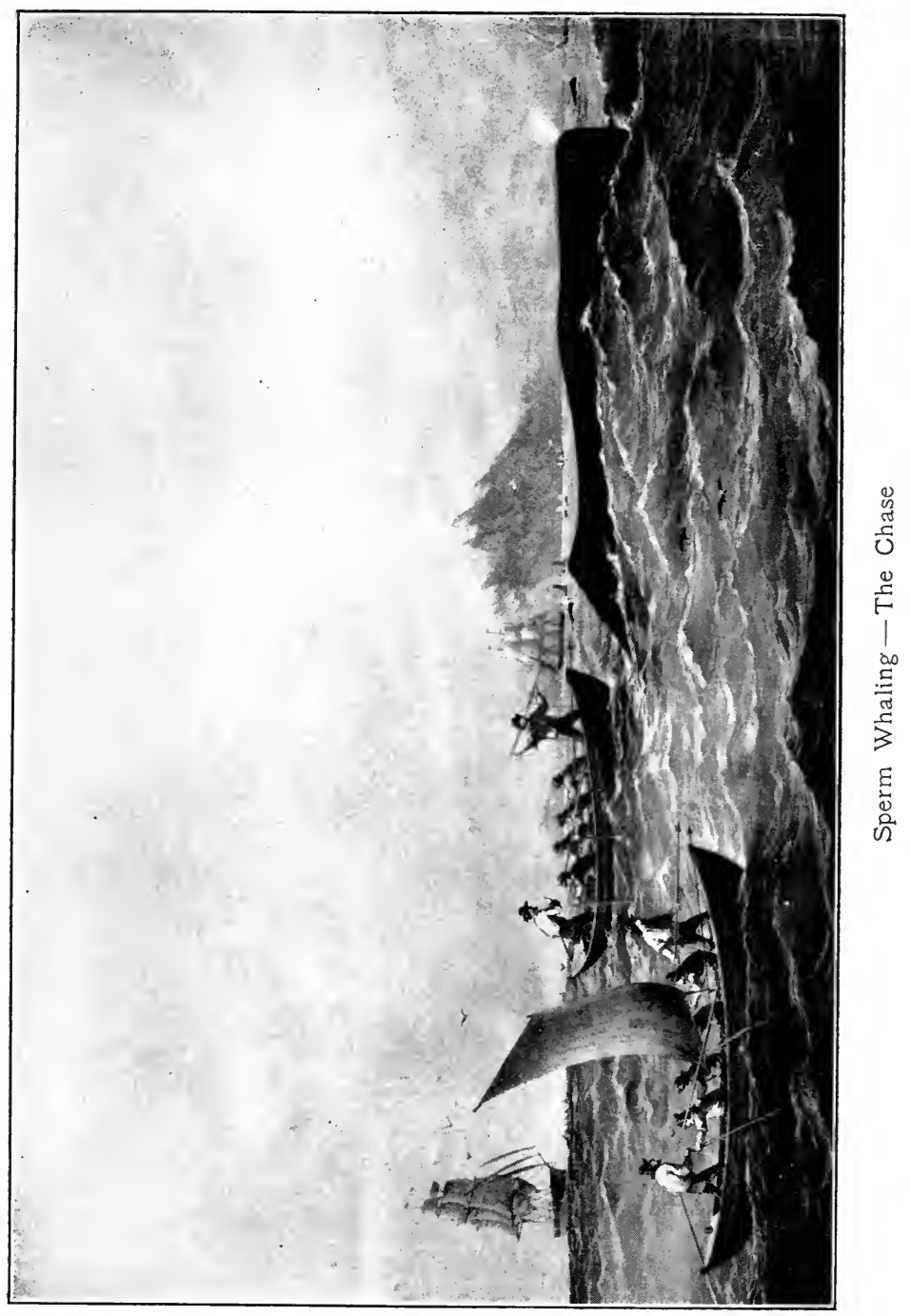



Whales as the Whalers Knew Them I 89

weapon into the whale's body. If he is slow in doing so, or if a passing wave drops the boat unexpectedly in contact with the whale before the harpoon is thrown, the whale usually sinks as swiftly as if it were a mass of lead; the harpooner is never able to strike his weapon into the whale after it has thus begun to sink.

Captain Davis described a peculiarity of the right whale as follows:

"On the tip of the upper jaw there is a spot of very limited extent seemingly as sensitive in feeling as the antennæ of an insect. However swiftly the right whale may be advancing on the boat, a slight prick on this point will arrest his forward motion at once. I think it safe to say he will not advance a single yard after the prick is given. He will either pitch his head and round down like a great wheel turning on a fixed axis, or he will turn shortly to the right or left according to the part of the nose which is pricked. Sometimes he will throw his enormous head straight into the air and settle backward tail first, by this motion exposing his whole throat to the thrust of the harpoon or lance; he may 
I90 The Story of the New England Whalers

take any course save the one directly forward. ... And it is also endowed with a backing power which is simply marvellous when we consider the enormous weight moving forward with great speed."

It is told of the whale of the northwest coast that it "practises a ruse de guerre by hollowing its back, causing the blubber to become loose or 'slack,' as it is termed, and preventing the harpoons from entering. Many a boat steerer has been dismayed by this manœuvre, and although the harpoon may have been thrown with all the force that could be summoned, the impetus was inadequate to penetrate the relaxed blubber and flesh." (The Whale Fishery.)

Whales are gregarious and gather in vast schools, as noted especially when migrating; that is to say, they did so in the days when there were enough whales to form such schools. In estimating the number of California gray whales seen along the Pacific coast in the migrating season, Scammon says (Marine Mammals of the Northwest Coast): "It has been estimated approximately by observing men among the shore 
Whales as the Whalers Knew Them I9r

whaling parties that a thousand whales passed southward daily from the $15^{\text {th }}$ of December to the first of February for several successive seasons after shore whaling was established [185I]. . . Accepting this number without allowing for those which passed offshore out of sight from the land, or for those which passed before the 15th of December or after the Ist of February, the aggregate would be 47,000."

Sperm whales were often seen in schools estimated in the thousands in the early days. Dr. Thomas Beale (Natural History of the Sperm Whale) says: "I have seen in one school as many as five or six hundred." That was written in I839, at a time when whale ships by the hundred had scoured the Pacific for more than twenty years and had greatly reduced the number of whales on the grounds visited by Dr. Beale.

The largest schools of sperm whales were composed of females and their young, with from one to three stalwart males in company, which were known to the whalers as "schoolmasters." Like land animals of similar habit, these lordly bulls 
I92 The Story of the New England Whalers

secured and maintained their positions by good fighting, and their aggressive character was frequently shown toward the whalers as well as toward venturesome individuals of their own kind.

The younger and smaller bulls - thirty-barrel whales - also went in schools which were not usually found near the larger schools of females. Then as the whalers cruised to and fro, they encountered big bulls, old and gray, that were swimming solitary and alone, though two were seen, now and then, heading the same course but at some distance from each other. These old bulls invariably showed the scars of battle, for they had been driven from the schools of females by younger and more vigorous fighters. "Whenever a lone whale meets with a drove [of females] he forthwith turns upon the male of the group and gives him battle," said the New Bedford Gazette, in 1837. "Their manner of fighting is bold and destructive. They run backward from each other several rods and then rapidly advance, their great square heads meeting with dreadful suddenness. The scene [of 
Whales as the Whalers Knew Them 193

a combat of the kind as described to the editor] was one of awful display. The two monsters, being among the largest of their species, advanced upon each other with their jaws, which measured sixteen feet in length, widely extended, exhibiting huge rows of great teeth, and presenting the most ferocious appearance. They cleaved much of the flesh from each other's heads and left deep marks of their teeth in other parts. In the affray one of them had his jaw slewed around and many of his teeth stove out, while the jaw of the other was broken off so that it hung to the head only by the flesh. It is said that these battles are not uncommon; and the conqueror always joins the drove of females and continues the cruise."

It is a curious fact that when whales with crooked jaws were killed by the whalers they were found to be as well nourished usually as the uncrippled whales; though Bullen notes three such whales, killed during his cruise, that were all "dry skins." How they could secure their food when the lower jaw for a part of its length could not be closed against the upper 
I94 The Story of the New England Whalers

jaw was a puzzling question, until some consideration was given to the feeding habits. Observation convinced the whalers that the sperm whale lived chiefly on the sepia octopus, the huge eight-armed creature that seamen called the giant squid. When in their death flurry, sperm whales often throw up the contents of their stomachs. Pieces of sharks and other kinds of fish have been ejected at such times, but pieces of the arms of this octopus were usually seen to the exclusion of other matter. As all fishermen know, the squid is attracted to any shining substance, - like a metal plate, for instance, that is lowered into the water. Now the mouth of the sperm whale is lined with a satinlike membrane that glistens with a metallic lustre when exposed under water. Undisturbed whales have often been seen lying at or near the surface with their lower jaws hanging down so that the inside of the mouth was plainly visible. Taking all these facts together, the whalemen came to believe that the sperm whales go into the depths where the giant squid usually passes its life, and when there lie motionless with their mouths 
Whales as the Whalers Knew Them 195

open. On seeing the white lining of the whale's mouth the squid, either from curiosity or in the pursuit of what it supposes is food, swims into the very jaws of its enemy. Thus even a whale with but a part of a jaw might secure prey. In support of this belief is the fact that blind whales (a fungous disease sometimes blinds the sperm whale) have been taken that gave as much blubber as one in perfect condition. The sperm whale should therefore be called a trapper rather than a hunter.

The brain of the whale is but a small bit of gray matter, if its size is compared with the bulk of its body. The skull of the larger sperm whale measures more than twenty feet in length. It is wedge-shaped with the edge of the wedge forward. The huge forehead that towers so high above the water is composed chiefly of flesh, gristle, and oil. Low down in the rear end of this huge skull is a cavity "seldom exceeding ten inches in length and as many in depth" that holds the brain.

A small brain may be exceedingly active, however, and all whalers are agreed that some 
I96 The Story of the New England Whalers

whales are more intelligent than others, and that the more intelligent ones sometimes show astonishing mental activity.

Of the mental characteristics of the whale it is noted first of all that the mother sperm (for example) shows a strong affection for her young. That the bowhead mother is seldom seen with her young nowadays is one of the curious facts of whale life, and whalers suppose that the young are brought forth under the polar ice and are kept there until large enough for weaning. When the whalers find a mother sperm whale and her young, they attack the young one first, if possible, knowing well that the mother will not desert it, and they will be able to secure her after killing the smaller one. The distress of the mother at such a time is manifest.

"But for all the notice taken by the whale she might never have been struck," says Bullen in describing an attack upon a mother whale with a calf by her side. "Close nestled to her side was a youngling of not more, certainly, than five days old, which sent its baby spout every now and then about two feet into the air. 
One long winglike fin embraced its small body holding it close to the massive breast of the tender mother, whose only care seemed to be to protect her young, utterly regardless of her own pain and danger.... While the calf continually sought to escape from the enfolding fin, making all sorts of puny struggles in the attempt, the mother scarcely moved from her position, although streaming with blood from a score of wounds. Once, indeed, as a deepsearching thrust entered her very vitals, she raised her massy flukes high in air with an apparently involuntary movement of agony; but even in that dire throe she remembered the possible danger to her young one and laid the tremendous weapon as softly down upon the water as if it were a feather fan. So in the most perfect quiet, with scarcely a writhe, nor any sign of flurry, she died, holding the calf to her side until the last vital spark had fled, and left it to a swift despatch with a single lance thrust."

Many a mother whale has been killed while thus striving to shield her young, for the whaler has the same contempt for sentiment that is shown by the butchers of wild animals on land. 
198 The Story of the New England Whalers

The females almost always show sympathy when one of their companions is attacked. They gather around the stricken one and act, the whalers say, as if anxious to render assistance. Through this habit the whalers have often secured two or three from a school of females. The cow whales also remain with their male companions in spite of danger. The first whale that Frank Bullen struck, he says, was a big bull that had a cow of small size for a companion. The cow followed the bull as it fled for life, and finally, after it was lanced mortally, she sounded with it. In due time the bull came up to the surface and died. Then Bullen found that his harpoons had been withdrawn from the dead bull, and yet the harpoon line was fast to something. Finally the cow came up much exhausted and it was easily killed. An examination of her carcass showed that the harpoon line was entangled with her teeth, "as if she had tried to bite in two the rope that held her consort," says Bullen, "and only succeeded in sharing his fate. I would not like to say that whales do not try to thus sever a line." 
Whales as the Whalers Knew Them I99

Young bulls, however, are animated by no such feeling. The moment one of their number is attacked they stick their heads into the air and seek a far country with all the speed they can command. It is a smart crew that gets more than one out of a "pod" of bulls.

That whales learn by experience, and very rapidly at-times, is well known to all whalers. The bowheads have long since learned that a ship is dangerous company, and they always feed near the ice.

"Persecution has made them shy and instead of roaming at large the whales only feed along the ice fringe where they can bolt to cover beneath the ice if attacked," says Captain Gray. "Nowadays whales are like rats or rabbits, never to be found far from their holes, particularly since the introduction of steam; they will never lie on banks where there is not sufficient ice to shelter them."

An incident of interest in any study of the mental characteristics of whales is an account of a chase of a couple of humpbacks as given in Bullen's book: 
200 The Story of the New England Whalers

"For a couple of days we met with no success, although we had a very aggravating chase after some smart bulls we fell in with. ... They went away gayly along the land, not attempting to get seaward, we straining every nerve to get alongside of them. Whether they were tantalizing us or not I cannot say, but it certainly looked like it. In spite of their well-known speed we were several times so close in their wake that the harpooners loosed the tacks of the jibs to get a clear shot; but as they did so the nimble monsters shot ahead a length or two, leaving us just out of reach. It was a fine chase while it lasted, though annoying; yet one could hardly help feeling amused at the way they wallowed along. ... At last after nearly two hours of fun they seemed to have had enough of it, and with one accord headed seaward at a greatly accelerated pace, as who should say, 'Well, s'long, boys.' . . . In a quarter of an hour they were out of sight."

The stories of what has been done by the fighting whales have seemed so remarkable that a special chapter is devoted to them. Of the 
Whales as the Whalers Knew Them 20r

other notable characteristics of these monstrous animals but one remains to be mentioned here. Alert, swift, and mighty, some whales of the fighting kind have defied for years the ablest whalers of the seven seas. With each successful resistance to attack such whales have seemed to gain in skill, and to increase in ferocity. The name of "Moby Dick, the White Whale," was taken from a fighting whale that was known to all whalers in the early part of the nineteenth century as Mocha Dick. Nevertheless a time came when a whale boat paddled up unawares upon even the mightiest and wisest of the fighters. The man at the bow was so skilful or so fortunate that he drove both harpoons "to the hitches" at a point where they, in part, at least, paralyzed the fighting spirit of the veteran. The mate then hurried forward, and before the animal had recovered enough of its customary strength to turn on the boat, the deadly lance was plunged into its side, and its "life". was reached. Flinching and bellowing under the intolerable pain it strove to fly, but the convulsions of death soon seized upon it. In wild agony it flung itself 
202 The Story of the New England Whalers

from side to side, while the clotted blood spouted high from its spiracle until life was almost gone. Then, with its last fleeting strength, it swam feebly in a circle until its head was toward the sun, and while lying thus - always with its head toward the sun - it turned on its side, "fin out," and died. 
HARPOONS, LANCES, GUNS, AND BOATS

$7 \mathrm{HE}$ earliest records of civilized whaling show that the harpoons then used were barbed spears something like those used by the aborigines, but pointed with iron or steel instead of stone or bone. A long line was attached to the harpoon, and by it the whale boat was kept connected with the whale into which the harpoon had been thrust, unless, indeed, the whale sounded, or dived, to a depth beyond the length of the line or in some way broke loose. When the wounded whale fled along the surface, the civilized whalers from the earliest times always strove to haul in on the line, until the boat was brought near enough to enable one of the crew to thrust a lance into the animal. The lance was simply an unbarbed spear, one that could be thrust in, and then withdrawn and thrust again. The harpoon and lance were 
204 The Story of the New England Whalers

better than the weapons used by the aborigines, chiefly because made of better materials; the form was not materially better. The civilized weapons were, in fact, evolved from those used by the aborigines.

The white men also used the aboriginal drag on certain occasions. When the whale sounded so deep that it was necessary to let go of the line, a drag (called "drug," usually) was attached to the end of it to impede, as far as possible, the progress of the whale. Indeed, at times "drugs" have been fastened to the line at intervals as it was running out. These drags were made of heavy plank.

Even in the use of the bow and arrow some of the white whalers have followed the aborigines. A letter from Captain Neils Juel, a whaler of Bergen, Norway, to Professor Spencer F. Baird (September 22, 1884), speaks of "the manner in which the fishermen" of Norway "kill the whale by means of arrows and cross-bow." "When a whale enters a bay," he says, "the passage is barred with a strong net and the whale is shot. They let him go for two or three days 
Harpoons, Laances, Guns, and Boats 205

inside. The arrows contain no poison, but later investigations have led to the discovery of a peculiar bacillus that lives on arrows already used, and which poisons the blood. Old arrows (of iron) are only esteemed, and now we know the reason why. After some days the whale becomes dying and is despatched with knives and harpoons."

Three kinds of harpoons have been popular among American whalemen. One with two barbs was called the "two-flued iron," another with one barb the "one-flued iron," and the third was the toggle-iron. The points and barbs of all harpoons were made of steel and welded to soft, tough iron shanks, except, of course, in the case of the toggle-iron, where the point and barb were made in one piece that was secured to the shank in such a way that it could turn around in the blubber, as the Eskimo toggle turned, until it lay across the end of the shank. The points and the forward or cutting edges of the barbs were always tempered and then sharpened to a razor edge. The boat steerers whetted them on the finest hones and then 
206 The Story of the New England Whalers

finished them on a strop, as one would put an edge on a razor. When not in pursuit of whales it was a common practice to put leather shields over the cutting parts of harpoons and lances.

The shank of the harpoon was about 30 inches long. The toggle of a toggle-iron was about six inches long. At the upper end of every shank was a socket into which a six-foot wooden handle was set. A hickory sapling with the bark on was much liked by able harpooners in other days, because the bark gave a good handhold. A short piece of the whale line was secured to the shank just at the socket by turns called hitches. It was then led halfway up the handle, and fastened there at two points by several turns of stout cord. When a whaler said that a harpoon was "in to the hitches," he meant that the full length of the metal part had been driven in.

Harpooners who had special pride in their work, some of those, for instance, who wore the chock pin as a badge of honor, had harpoons made for their private use. Well-worn horseshoes and horseshoe nails were much used in 


\section{Harpoons, Lances, Guns, and Boats 207}

forging these special weapons, and razor steel was used in making the cutting edges and points.

The first toggle-iron made for an American whaler was forged by Lewis Temple, a negro harpoon maker living in New Bedford. He introduced it in the year 1848 , and it has been the most popular harpoon among American whalemen since that year. (T he Whale Fishery.)

In I850 Captain C. F. Brown, of Warren, Rhode Island, invented a harpoon that had a chisel-shaped point. The sides of the chisel were not sharpened to a cutting edge and the barbs were both twisted to one side in a curve like the thread of a screw. The forward edges of ordinary harpoons were necessarily sharp and they sometimes cut so large a hole in the flesh of the whale that the harpoon drew out when a strain was brought on it. The curved, flangelike barbs of the chisel-pointed harpoon, it was supposed, would engage themselves in uncut flesh when a strain was brought on the harpoon, and hold under all circumstances. The conservative whalemen, however, never took a fancy to this invention. 
208 The Story of the New England Whalers

"I have seen the shanks of harpoons that have been twisted into the most questionable shapes by the actions of dying whales; some had complete circles or loops bent into them, and none of the instruments could be used again until forged anew. When the whale is towing the boat the shanks of the harpoons, usually the portions known as the necks, are sometimes reduced in diameter by tractile force. That the fibres of cold iron can be drawn out in this manner has been doubted by sceptics, but it does not seem improbable to persons who are familiar with the ductility of metals, or with the great strain brought to bear upon the harpoon when a boat is towed through a heavy sea, and more particularly when a harpoon is fastened under the rib of a whale. I have seen very interesting specimens of this character, and in the fall of I882 I sent three stretched harpoons to the National Museum. Sometimes the harpoon breaks, and the portion which remains in the whale may be long afterwards cut out by the crew of the same or another vessel. Owing to the marks, the instrument may be easily identified. The wound becomes 
Harpoons, Lances, Guns, and Boats 209

cicatrized, and perhaps after many years, by attrition, the projecting shank may be worn to a mere shred. A boat steerer belonging to the Ansel Gibbs, of New Bedford, threw his harpoon into a bowhead whale in Hudson Bay, and several years afterwards the Cornelius Howland, of New Bedford, captured the same whale in the Arctic regions on the western coast. The whale had traversed the great northwest passage, which is yet unknown to man, and carried with it the harpoon, which was branded with the names of the Gibbs and of the blacksmith [Jireh Swift] who made it." (James Templeman Brown, in The Whale Fishery.)

All the harpoons belonging to every whale ship were marked with names, letters, lines, dots, etc., made with a cold chisel in such a way that any one finding a harpoon in a whale could tell not only what ship it was from, but also the boat from which it was thrown. This was done because of the whaler's rule of the chase which said that "marked craft claims the fish, so long as it is in the water, dead or alive."

The Whale Fishery says that "the books of 


\section{I0 The Story of the New England Whalers}

Mr. James Durbee, the veteran harpoon maker of New Bedford, show that from 1828 to 1868 he made and sold 58,517 harpoons." During that long period there were from eight to ten other harpoon makers in that one port, and all were kept busy.

Every whale boat that was lowered carried two "live" harpoons, - the two that were secured to the whale line ready for use. One of these live irons was fastened to the end of the whale line. The other one carried a short line the loose end of which was looped around the main line. The harpooner threw the first iron into the whale. Then he picked up the second iron and tried to throw that into the whale, also. If he failed, he threw it overboard to get it out of the way; for if jerked over by the plunging whale, there was no telling what damage it might do as it was going. Thereafter this harpoon rode on the main line; it was usually seen, dragging in the water just under the bow of the boat, where it justified the adjective "live" that was applied to it.

Besides the live irons each boat carried two 
Harpoons, Lances, Guns, and Boats 2II

'or three spare ones. Each ship carried from three to five boats ready for lowering when whales were seen, and thus from twelve to twenty harpoons were carried from the ship whenever boats were lowered. Of course every ship carried a supply of spare harpoons, and as there were hundreds of whale ships in commission all the time, it is easy to see how it happened that many harpoons were made during the period mentioned above.

The lance was composed of a flat, oval-shaped steel blade, sharp as a razor, welded to a tough and stiff iron shank six feet long. A wooden handle six feet, or thereabouts in length, was inserted in a socket at the upper end of the shank. A whale line a few fathoms long was fastened to the lance. As the whaleman drew in near the flying whale that had been struck by a harpoon, the man at the bow darted the lance at the whale even when it were not possible thus to reach a vital part; for every wound bled freely and weakened the animal in its struggles. At each throw the lance was drawn back by the line for another dart, until finally the boat was 
212. The Story of the New England Whalers

drawn within reach of the shoulder, when the lance was thrust into the 'whale's vitals and "churned" up and down.

Among the earlier colonial laws that now serve to amuse the student of history was one providing a penalty for every instance when a whale was "foolishly lanced behind ye vitals."

Another weapon used in the earlier part of the fishery was the boat spade. It consisted of a flat, triangular, chisel-like blade, five or six inches wide on the cutting edge, and perhaps twice as long, which was secured to a six-foot handle by means of a socket. It was provided with a line by which it could be recovered if dropped overboard. Nothing ever done by American whalemen shows the reckless courage of the race as well as the use of the boat spade. For when, as the boat was drawn in alongside, the man in the bow saw the whale raise its tail in air for a dive, he slewed the boat in under the uplifted flukes and drove the spade into the root of the tail and cut off so many of the tendons and muscles as utterly to disable the monster.

"There is one case on record," says James 


\section{Harpoons, Lances, Guns, and Boats 213}

Templeman Brown, "that has come under my observation when an officer actually unjointed the flukes by a tremendous and well-directed blow of the spade. The whale was in a favorable position, the uplifted flukes producing a tension, and the caudal fin, though still connected, hung to one side."

"Spading flukes is one of the lost arts of the fishery;" he continues. "We should naturally think that it would be far preferable to stand off at a safe distance and kill the huge floundering cetacean with an explosive lance fired from a gun. ... Not so with the broad-chested, whitehaired whalemen of the old school, who regard the modern gun as a travesty upon their forefathers."

The warp in the early days was made of fine hemp, but in modern days the manila fibre has been preferred, because it is at once stronger and more pliable. Says Melville:

"The whale line is only two-thirds of an inch in thickness. By experiment its 150 yarns will each sustain a weight of 120 pounds; so that the whole rope will bear a strain nearly equal to three tons." 
214 The Story of the New England Whalers

"The whale line is laid in Flemish coils [i.e. in flat, concentric coils, one on top of the other], 225 fathoms in the large tub and 75 fathoms in the small tub, which each whale boat carries," says $T$ be Whale Fishery. "The upper and lower ends of each line are exposed and provided with eye-splices in order that one end of the line may be made fast to the harpoon and the other end to the other line when fast to a whale. Each boat carries 300 fathoms of line, and if a whale, by running or sounding a great distance, takes it all out, another boat is signalled and assists in the capture."

Scoresby tells of a Greenland whale that drew out six miles of line, with fifteen harpoons attached, and carried down a whale boat with all hands before it was killed. Usually a whale takes out no more than 200 fathoms - 1200 feet - of line.

The most important weapon used in the modern fishery is the whaling gun, of one of the forms now to be described. Among the weapons used on war-ships in the seventeenth and eighteenth centuries was the swivel cannon. It was usually 
Harpoons, Lances, Guns, and Boats 215

made of cast iron with the bore large enough to accommodate a one-pound, cast-iron ball. Guns of this kind were mounted on the rails of war-ships by means of swivels, and for short range were convenient and fairly effective. Knowing all about these swivels, some whaleman, as early as I73I, invented a swivel from which a harpoon could be fired at a whale. The art of aiming cannon had not yet been acquired by the seamen of the world, however, and when the whalemen tried to aim this harpoon gun, while the boat was dancing and plunging over the waves, they found that they could not hit the target. The use of slow matches (percussion caps had not been invented) was another drawback. Moreover the harpoon line proved so much of a drag on the harpoon that the range of the gun was limited. The frames of the whale boat were not strong enough to bear the strain of the recoil of the gun, and when the frames were made heavier the whalemen were unable to row the boat as swiftly as was necessary. When two or more boats gathered around a whale, and all began to fire at it, the chances of 
216 The Story of the New England Whalers

hitting one of the boats with the gun-thrown harpoon were greater than the chances of hitting the whale. The gun was therefore soon discarded, and when in 1771 and 1772 it was tried again, it proved as unpopular as before.

In the nineteenth century the swivel gun for throwing a harpoon was again offered to the whalers. Niles' Register of May 24, I8I7, mentions the use of such a gun by the whalers of Bermuda. A British gunmaker named Greenei and a Norway inventor named Svend Foyn made guns that were mounted on the bows of whale boats in such a way that they could be pointed in any direction speedily. Greener's first guns had the old flint-locks. Foyn added an explosive bomb to his harpoon, and it was arranged so that it would explode after it had penetrated the whale and not before.

The harpoon for use in a gun is made entirely of metal. The end of the handle is a disk that fits in the bore of the gun resting on the powder charge. The handle is in two parallel parts, and a ring, to which the harpoon line is attached, slides freely to and fro in the slot thus formed. 
When the harpoon is placed in the bore of the gun, the ring slides to the head of the harpoon. When the gun is fired, the harpoon carries the ring with the line trailing away behind. If the gunner fails to hit the whale, or if the first harpoon fails to kill the animal, other harpoons are at hand ready for more shots as opportunity may offer. On the coast of Norway and in the Iceland waters the harpoon guns, as invented by Foyn, are popular. Foyn himself made a fortune using his own gun. On the Pacific coast of the United States the Greener gun has been used. The range of these swivel guns is placed as high as 84 yards. In America, however, the harpoons thus used had no bomb attached. The bombs are fired from another kind of gun. In 1847 the following, from the Nantucket $E_{n}$ quirer, went the rounds of the newspapers printed in the Atlantic ports:

"We saw yesterday at the store of Captain E. W. Gardner a very curious contrivance for killing whales. It is a short gun weighing some twenty-five pounds - the stock being of solid brass - from which a harpoon is to be fired into 
218 The Story of the New England Whalers

the animal. The handle of the harpoon goes into the gun about a foot, and a line is fastened to it, of course outside the gun, by which the whale is to be held.

"There is also a bomb lance for the purpose of killing the animal. The instrument is loaded with powder, and a slow match is led from the magazine to the end which goes into the gun. When the lance is fired into the whale the slow match ignites; and in about half a minute the fire reaches the powder which is in the head of the instrument, which instantly explodes, killing the animal outright. At least, this is what the article is intended to do.

"The whole apparatus is certainly very ingenious; whether or not it is really an improvement on the present mode of killing whales is more than we are able to say. That is a question that must be settled by the whalemen themselves."

Any study of the history of the sea shows that sailors and shipowners are the most conservative people in the world. It was thirty years after Fulton made a success on the Hudson before 
Harpoons, Lances, Guns, and Boats 219

steamers for crossing the ocean came into use. The compound engine was in use on the Great Lakes before $185^{\circ}$, but salt-water owners refused to adopt it until after I870. Ericsson made a practical screw propeller before I 840 , and men-o'war used it within five years; but the merchantship owners were building side-wheel Atlantic liners until after I860. The gun that could be fired from the shoulder to throw a bomb into a whale was to come into universal use only after the whaling business had died down to a small fraction of what it was when the gun was introduced.

The muzzle-loading gun described in the Nantucket paper is now known as the Brand gun, and it is still popular on Cape Cod, though about as much out of date as the hand lance. Three sizes have been in use in the fishery, the bore being from seven-eighths of an inch to an inch and a quarter in diameter, and the weight of the gun from 23 pounds down to 18 . The charge of powder was but three drams. C. C. Brand of Norwich, Connecticut, was the inventor of the old smooth-bore shoulder gun. 
220 The Story of the New England Whalers

The bomb lance to be fired from a shoulder gun was invented by Robert Allen, also of Norwich, Connecticut. It was merely a long metal tube, filled with powder and fired by means of a time fuse. As it was fired from a smooth-bore gun, and was unprovided with wings or feathers of any kind to keep it travelling end-on, it was quite likely to strike the whale "broadside to," and fail to penetrate far enough. It was not only ineffective in such circumstances, but it was likely to prove dangerous to the whalemen by exploding as it lay on the surface of the whale, and throwing pieces of the metal in all directions.

In 1852, however, Brand improved the bomb by giving it feathers such as the Indians used to affix to their arrows, only rubber was used instead of feathers from a fowl. As thus improved, the bombs are now used.

A curious accident occurred in connection with the use of the bomb harpoon of Norway. In I895 a dead whale, into which more than one harpoon had been fired, was brought alongside the little steamer on which the gun was mounted. The steamer was to tow it to the beach near the 
Harpóons, Lances, Guns, and Boats 22I

try-works. When the whale had been well secured to the steamer, a live bomb that was in the whale's blubber suddenly exploded. The explosion opened a hole in the vessel, which sank so quickly that the crew had barely time to escape.

In May, 1877, the New Bedford Mercury had the following:

"During last year Captain Eben Pierce, the well-known manufacturer of bomb lances, and Selmar Eggers . . . perfected . . . a breech-loading whaling gun varying from the ordinary weapon as much as a modern sixteen shooting rifle does from the flint-lock shot-gun of our ancestors.

"The great superiority of this weapon lies in the manner of loading. The old guns were loaded with loose powder, and were more dangerous to handle when charged; the powder would also become dampened with flying spray when in a boat that was going through the water at a lively rate, and it has often occurred that when the pursuers had arrived within easy range of their prey they would find the charge moistened, and the weapon consequently useless. Mr. Eggers' 
222 The Story of the New England Whalers

gun is so constructed that by touching a spring in the butt, a chamber in which the barrel terminates is opened. Into this a cartridge is inserted. It is charged with $2 \frac{1}{2}$ drams of powder, or about half the quantity used to load the ordinary guns. The chamber is then closed. Upon pulling the trigger the hammer strikes a sharp blow upon a cap in the end of the cartridge, and the piece is discharged. The whole operation of loading, firing, and reloading can be accomplished in two minutes' time. . . . The gun is much surer and safer, as these cartridges can be kept in the pocket until needed; and no water can lessen their power after they are placed in the chamber. With the breech-loader, a lance can be sent with destructive effect over $75^{\circ}$ feet, if fired at a slight elevation. The weapon is constructed of gun metal and is thus almost impervious to wet."

Cunningham and Coogan, a New Bedford firm, brought out another breech-loader, with a bomb lance for a projectile. Each style of gun has its friends. It is said by whalers that all three kinds of guns herein described are effective, and that all 
Harpoons, Lances, Guns, and Boats 223

of them "kick" with amazing power whenever fired. It is, therefore, customary to use a lanyard to secure every gun to the boat in such a way that if the gunner should be kicked overboard, the gun can be recovered!

Bomb lances, in late years, have been made from 17 to 19 inches long, and from a pound and a quarter to two pounds in weight. The bursting charge is about two ounces of powder. In using these bomb guns the whale is first struck with a harpoon thrown by hand, the boat is drawn up within range as soon as possible - within from 30 feet to 30 yards - and then a lance is fired into the animal.

The darting gun is the latest style of bombthrowing weapons. It was invented by Captain Eben Pierce and Patrick Cunningham, of New Bedford. A gun barrel is attached, with its muzzle end down, to a harpoon. The gun barrel is provided with a trigger in the shape of a rod of metal that projects beyond the muzzle. Having loaded the gun, the combination of harpoon and gun barrel is thrown at the whale. The harpoon sinks into the whale and holds the boat to the 
224 The Story of the New England Whalers

animal by means of a line, as usual. As the harpoon is thus made to penetrate the whale, the metal-rod trigger strikes against the skin of the whale, discharges the gun, and the bomb lance is thus fired into the whale. The Whale Fishery says that "were it not for this kind of gun, ice whaling could not be successfully pursued." That is to say, that the whales found along the ice fields are now so shy, and hover so close to the ice, that if struck by an ordinary harpoon they would escape under the ice before a bomb could be fired into them from an ordinary gun.

Still another weapon - the whaling rocket was invented by Patrick Cunningham. Cunningham is known to most seafaring people as the inventor of a line-carrying rocket used by the lifesaving stations for carrying lines to stranded ships. This rocket was modified so that a barbed harpoon point was fixed to the head. A gun barrel loaded with a bomb lance was attached beside the rocket, and the combination was so arranged that the rocket in its flight would strike the whale, the harpoon would penetrate, and the gun would then fire the bomb into the whale. 
Harpoons, Lances, Guns, and Boats 225

The rocket gun has been found useful chiefly in the alongshore fisheries, where boats larger than the ordinary whale boat are desirable.

The use of a net for taking whales has been mentioned. In 1848 Captain Josiah Ghenn, master of the schooner Council, while cruising off the coast of Labrador, made a net 150 fathoms long by 8 deep, and set it as a trap near the beach, hoping to catch a bowhead in it. A bowhead entered the trap, but on becoming somewhat entangled, it swam away out to sea.

"And I have never seen that whale or net since," said the captain, in relating the story to the writer of $T$ be Whale Fishery.

In an essay on Whale Fisbing in the Faroe Islands, Mr. S. H. C. Muller described to the International Fisheries Exposition (Glasgow, I882) a net that is used in those islands for taking blackfish, as the grind or pilot whale is called. This net is usually 200. fathoms long by 8 deep, and is made of nine-yarn rope. It has been found very useful in holding the small whales within narrow waters until the fishermen can go among them and use the lance. 
226 The Story of the New England Whalers

These blackfish are only twenty-two feet long at most At one point on the coast of New Zealand a station has been established for the express purpose of taking right whales with a net. The following, regarding this station and its net, was written by Mr. Allen Kelly, and published in Forest and Stream on July 21, 1906:

"Wangamumu is a little bay on the east coast, a few miles south of a prominent cape which juts out to the northeast and might easily be mistaken for the northeastern extremity of the North Island. During May and June the Antarctic whale migrates north into warmer waters, and it seems probable that there is some set of currents around the headland of Wangamumu which deceives him into seeking a passage to the Tasman Sea by boring into the shore at that point. Whatever may be the cause, the fact is that schools of whales hug the shore and pass very close to a great jutting rock at Wangamumu.

"Straight out into the sea from the point of rocks is stretched the whale net, made of threequarter inch wire rope in six-foot mesh, each mesh being formed of separate sections of rope 


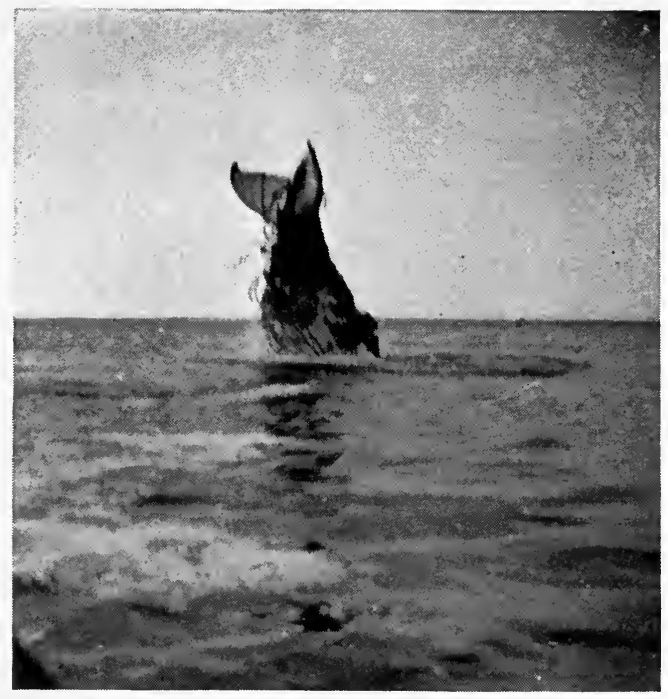

Entangled Whale Diving 



\section{Harpoons, Lances, Guns, and Boats}

attached to iron corner rings, taking the places of knots. The top edge of the net is held close to the surface by barrels serving as buoys. . A whale cruising along the shore gets his head through a mesh, and instead of attempting to back out, he rushes forward and entangles himself hopelessly in the net. . . F From a lookout station on the top of the headland a watcher signals the approach of whales, and the boats put off and lie in wait. An entangled whale carries away the net with a rush, but the great weight of the wire rope and the drag of a long line of buoys impede him, and instead of heading out to sea and going away with the whole outfit, he thrashes about and soon gets fins and flukes entangled, when the boat approaches and the whalers finish the business with the lance as in the old days."

Plans for poisoning whales with prussic acid were evolved in England in 1831. The Scientific American of September 8, 1860, says:

"A paper has just been published in England by Professor Christison on the result of some experiments suggested as long ago as $183 \mathrm{I}$, by W. \& G. Young of Leith, for the capture of 
228 The Story of the New England Whalers

whales by means of prussic acid. The subtile poison was contained in tubes, in quantity about two ounces. Among other difficulties one was to discharge the poison at the right time. After various trials the plan fixed upon was to attach firmly to each end of the harpoon near the blade one end of a strong copper wire, the other end of which passed obliquely over the tube, thereby - securing it in its place; then through an oblique hole in the shaft, close to the upper end of the tube, and finally to a bight in the rope where it was firmly secured. By these means the rope could not be drawn tight (as it would be when the harpoon attached to it struck the whale) without crushing the tubes; the poison would then enter the whale and death ensue. Messrs. Young sent a quantity of the tubes charged with poison by one of their ships engaged in the Greenland fishery, and on meeting with a fine whale the harpoon was deeply buried in its body; the leviathan immediately 'sounded,' but in a very short time the rope relaxed and the whale rose to the surface quite dead. The men were so appalled by the terrific effect of the poisoned harpoon that they declined to use any more of them." 
Harpoons, Lances, Guns, and Boats 229

The Whale Fisbery, in speaking of the use of prussic acid, says that "American whalemen unanimously attribute the inauguration of this enterprise to the French." Niles' Register, on September 2, 1843, said that a French naval surgeon had invented a tube-carrying harpoon of a design that would spill the poison into the wound, and it adds that such a method had been proposed in Baltimore as early as 1837 . F. C. Sanford, of Nantucket, is authority for the statement that the ship Susan, that sailed from Nantucket on November I7, I873, carried poisoned harpoons. They were not used by the crew, however, according to the mate of the vessel, $\mathrm{Mr}$. Charles E. Allen, also a resident of Nantucket. Mr. Samuel Tuck, of Williamsburg, Brooklyn, New York, who was agent for the Susan, told Mr. James Templeman Brown that the harpoons were forged on Nantucket with slots in the head where slender tubes of poison could be placed. Two harpoons made in this fashion are now displayed in the National Museum.

Captain William Adams, a Scotch whaler, wrote to Professor Baird as follows: 
230 The Story of the New England Whalers

"During the winter of I86I a large two-grooved rifle was made by Messrs. Dixon, of Edinburgh, from plans and instructions of Mr. James Miln, of Murie. The weight of the rifle was 28 pounds. Shells were made for it and filled with one-half ounce concentrated prussic acid and a small charge of powder fired by a ten-second fuse."

On May I2, I862, one of these shells was fired into a whale. "She went under for four or five minutes, and on coming up another was fired into her. She then seemed quite helpless. Three gun harpoons were then fired into her as she lay on her side. At 12:30 P.M. she was quite dead. We had no difficulty with the men in regard to the poison, but we never got another chance to use it."

An official list of patents issued by the United States Patent Office for the week ending March 30, I852, shows that Dr. Albert Sonnenberg and Philipp Rechter, of Bremen, Germany, had secured a patent for an "electric whaling apparatus." "We claim," said the inventors, "the application of electric galvanic current by a conductor to an instrument which is thrown into sperm and right 
Harpoons, Lances, Guns, and Boats 23I

whales, as well as other animals of the sea, in order to secure them." The whale boat for this machine was made longer than the ordinary one. A "magneto-electric rotation machine" was provided to supply the current, and a wire from this machine through the whale line to the harpoon conveyed the current into the whale. Having struck the whale with this harpoon, the boat's crew were to grind away merrily on the machine while it transmitted "eight tremendous shocks or 960 strokes per minute, so formidable a power that no living being can resist the same." The current was to return through the water, the bottom of the boat being coppered to facilitate the flow.

Last of all to be described in connection with the weapons is a reel used on the Norwegian steam whale boats for "playing" a whale after it has been struck with the harpoon that is fired from a swivel gun. The harpoon line used there is of soft hemp and about as thick as a man's wrist. All of the line, except the necessary slack that is coiled beside the gun, is wound on the spool of a steam winch. When a whale is struck 
232 The Story of the New England Whalers

by a harpoon, but not killed by the attached bomb, the wounded animal plunges to the bottom or swims away at its utmost speed. At this time the man at the winch pays out as much line as he must, but keeps a heavy strain on it. When the whale slackens its speed, or in any way eases the strain, the line is wound in, but only to let it out again, if the whale makes another plunge. The man at the winch literally plays the whale as a rod fisherman plays a trout or salmon, until it is finally brought within reach of another bomb.

As the models of harpoon and spear were developed from the arrow and the spear of the aborigines, so, it may be said, the whale boat is but a larger and stronger birch-bark canoe. The first civilized whalers of America used such boats as were carried by the ships that crossed the sea. But from Long Island to the coast of Maine the colonial whalers had ever before them the lightweight canoes, sharp at both ends, that were used by the red whalers. The Indians in their canoes dashed in alongside the whale, plunged home their weapons, and then, with a stroke of the paddle, turned away, dodging the flukes and 
Harpoons, Lances, Guns, and Boats 233

escaping immediate danger, only to return again for another attack. In speed and handiness the canoe model was not excelled by any then known to the white men. Therefore, in spite of race prejudice, inherited from the brutal days when every man's hand was against his neighbor, the white whalers adopted the red man's model.

The whale boat was sharp at both ends and could be driven astern as readily as ahead. Giving the boat great sheer - building the bow and stern high out of water - enabled it to throw off the waves of a rough sea, and also made it less likely to turn over when struck by a flaw of wind. Then, still following the canoe model, the floor was made nearly flat so that the crew could turn the boat swiftly and dodge the onslaught of a wounded whale much as the Indians did. Oars were used by the white whalers from the first, but they also adopted the Indian paddle, because paddles made less noise and disturbance in the water. Finally sails were added to the boats of the white whalers, partly because a sailing boat could run on to a whale without disturbing it, and partly because sailing saved the work of rowing. 
234 The Story of the New England Whalers

Since 1860 the usual length of the whale boat has been 28 or 29 feet. A 28 -foot boat is 20 feet long on the keel, 5 feet 8 inches wide, and 26 inches deep. The keel is " 4 inches in rocker"; it is bent in the shape of a bow. The sheer or upward curve of the rails was 15 inches above the horizontal plane amidships in former days, but it is made less in these days. All framing is made of white oak and the planks are of cedar. The ribs are but half an inch deep. Inch-pine boards are used for thwarts. A mast is stepped through a hole in the forward thwart. Centreboards are located where needed. The stem rises above the rail, where it is shaped like a $\mathrm{Y}$, in the bottom of which is a brass roller or a lining of lead to form a smooth fairway for the whale line. A shallow box is built something like a forecastle deck in the bow of the boat. On this are coiled the spare ends of the whale lines that are attached to the "live" harpoons. At the stern of the boat a stout timber head rises from the keel up through a short deck, and it is well supported by knees. The whale line is taken from the tub to this timber head, around which two or three turns are 


\section{Harpoons, Lances, Guns, and Boats 235}

taken in order to bring a strain on the line when a struck whale is sounding. The friction of the line flying around this timber often sets it on fire, and it is necessary to throw water over it. The weight of a whale boat ready for the ship is from 500 to $55^{\circ}$ pounds. One in the National Museum with its load of weapons, lines, etc., weighs 1528 pounds. The boat is usually steered with a I9-foot oar, but a rudder is carried. The oars range from 9 to 16 feet in length, and the shortest is placed at the bow. The 28-foot boat formerly sold as low as $\$ 90$, but the prices are now far above \$Ioo.

The ordinary whale ship of what was called the Golden Era of the nineteenth century carried four boats on the davits, - one aft on the starboard side, called the "captain's" or the "starboard" boat; one aft on the port side, called the "larboard" boat; one on the port side abreast the mainmast, called the "waist" boat; and one forward on the port side, called the "bow" boat. The first, second, and third mates had charge of these boats on the port side in the order named. The harpooner of the captain's boat took charge 
236 The Story of the New England Whalers

of it when the captain wished to remain on the ship.

Every whaler carried two or three spare boats and plenty of lumber for making repairs. Some modern whalers carry from five to seven boats on the davits ready to lower, but they keep the starboard waist clear because it is there that the whale is secured when its blubber is to be saved. The small schooners that now haunt the Atlantic grounds carry two or three boats on the davits, and a spare one on "the tail feathers," as the davits at the stern are called. The davits are made of stout bent timbers, that rise about ten feet above the rail in order to hold the boat above the waves. Iron davits have been tried, but they were not approved. Whale boats are usually worn out in one voyage, even when they are not destroyed by the whales. They are thrown violently against the side of the ship when lowered in a seaway; the race to reach the whale is something of a strain, and the race after the whale is struck, when they are dragged through - literally through - the waves at a speed of from six to twelve knots an hour, is a greater one. When the 
whale sounds, the strain on the line lifts the stern high in the air while the bow is depressed until the rail is just awash. After the racking of a cruise of forty months, no one cares to use the boats for a new voyage.

The original deep-water Nantucket whaler was a sloop of thirty to forty tons, - a vessel of the size of the oyster sloops that are to be seen in the Atlantic ports. Such vessels as these, and even larger ones, were built back in the woods, at times a mile from the water. When ready they were lowered down on huge sleds and drawn by a hundred yoke of oxen to the water side. The men who built the ship manned it. Nantucket men (or women) also wove the canvas for their sails, beginning in I792, and a newspaper item of that time says that the looms employed more hands than the five ropewalks that were then in existence on the island. The cost of the small whale ships of the eighteenth century was nominally from $£_{3}$ to $£_{5}$ per ton register.

During the nineteenth century the Pacific whalers were from 200 to 450 tons register, usually. A ship like the Charles Phelps, built at Westerly, 
238 The Story of the New England Whalers

Rhode Island, for Stonington owners, and registered at New London on August 23, 1842, was a favorite size. As described by James $\mathrm{H}$. Weeks in the Westerly Sun (January 2, I900), she was 107.5 feet long by 27.5 wide and 13.75 deep. She measured $362 \frac{19}{5}$ tons. Such a ship and her outfit cost from $\$ 60$ to $\$ 70$ a ton. In 1847 a writer in Hunt's Merchants' Magazine boasted that New London owned "the largest and the smallest whalemen in the world, - the ship Atlantic being 699 tons burden, while the schooner Garland is only 49 tons." The Atlantic lost her captain, William Beck, during that voyage, but she saved a cargo worth nearly $\$ 80,000$. Though the largest whaler in the world, she was yet shorter than the sloop yachts that have in recent years sailed for the America's cup in the races off Sandy Hook.

The first steamer employed in the whale fishery was the Innuit. She left Peterhead, Scotland, for the Greenland grounds in 1857 , and came back at the end of three weeks with 150 tons of oil. This good luck led the owners of many steamers to venture into the Arctic whale fishery; but out 
Harpoons, Lances, Guns, and Boats 239

of fifty-two vessels that were so employed during the next two years, so many were lost in the ice that steamers went out of style almost as rapidly as they had risen in favor. Then the work of building steamers, especially for the fishery, was begun, and ever since that time steam has had a firm hold on the whalers of the world.

The first American steam whaler was the barkrigged Pioneer of 212 tons register. She had been built for a transport during the Civil War. In 1865 Williams and Havens, of New Bedford, rebuilt her and sent her to Davis Straits. She reached home on November 14, I866, with 340 barrels of oil and 5300 pounds of bone. In her next cruise she was crushed in the ice. ( $\mathcal{T}$ be Whale Fishery.) The first steam whaler to make a notable success was the Mary and Ellen, built by William Lewis and others, of New Bedford, especially for the purpose. She measured 508 tons. She sailed September 9, I879, for the North Pacific, under Captain L. C. Owen, and on October 10, I880, reached San Francisco with 265 barrels of sperm oil worth $\$ 28$ per barrel, $235^{\circ}$ barrels of whale oil worth \$I6 per barrel, 
240 The Story of the New England Whalers

and 45,000 pounds of bone worth $\$ 2$ a pound. She was afterward sold to the United States for use in the search for the survivors of the feanette Expedition, and was accidentally burned on November $30,188 \mathrm{I}$. The success of this ship, and that of another which her owners built to take her place, made the use of steamers popular for the Arctic fishery. The American whale fleet of I880, including outfit and steamers, was valued at $\$ 70$ a ton.

Perhaps the most interesting novelty adopted by American whalers was a steam whale boat. The noise made by a propeller was the chief objection to such a craft. Whales were and are so wary that they are sometimes frightened by the approach of a boat under sail; that a boat with a whirling screw under its stern should ever get alongside a whale seemed impossible. Nevertheless, in 1882, at the suggestion of Lieutenant Z. L. Tanner, U.S.N., the firm of J. H. Bartlett and Sons, of New Bedford, sent a 28-foot steam cutter, of the navy pattern, but fitted to burn "scrap," with their bark Rainbow, Captain Bernard Cogan. Aldrich, previously quoted, saw the 
Harpoons, Lances, Guns, and Boats 24I

launch in use in the Arctic fleet during the year I887.

"Eight vessels, two steamers, and six sailing vessels were at anchor in the bight under Cape East, Siberia," he wrote. "Immediately after dinner, one day, the lookout on. the southernmost vessel raised the cry of 'b-l-o-w!'. The echo of his call had scarcely died away before the whale boats of this vessel dropped from the davits into the water, set sail, and scattered about to watch for the next appearance of the whale. Boats from the other vessels were not far behind, and within five minutes from twenty-five to thirty white sails were darting over the water, each boat's crew hoping to be nearest the spot where the whale should rise to blow.... A great shout came from all sides, and a ' $b-\mathrm{l}-\mathrm{o}-\mathrm{w}-\mathrm{w}$ ' sounded from each crow's nest as the whale's head appeared above the water within striking distance of the Lucretia's boats. There was a quick manœuvre, the boat steerer darted his harpoon into the whale, and 'fast boat!' resounded from every vessel. It was a magnificent sight as the whale milled about and started out to sea at a high rate of speed, 
242 The Story of the New England Whalers

towing the boat after him. The boat steerer had struck the whale abaft the vitals ... so that it was yet far from certain whether he would be captured.

"The whale went out to sea two or three miles, towing the boat at such speed that it did not ride over the waves but cut through them, throwing spray like a torpedo boat. Then he turned about and doubling his wake sought the protection offered by the shore ice near the ships. The instant the whale headed shoreward four of the captains and I took the only steam whale boat in the fleet and joined in the chase, as there was little hope of saving the whale unless more bomb lances could be shot into him, and as yet not one of the other boats had had opportunity to shoot him.

"At the north end of the floe was a bight in the ice. The whale passed in under the ice and suddenly appeared in this bight to blow.... Before he could sound our boat had steamed into the bight and was alongside of him. The captain of the Lucretia stood in the forward end of the boat with shoulder gun in hand ready at 


\section{Harpoons, Lances, Guns, and Boats 243}

the proper instant to shoot; and the master of the Eliza stood amidships, also with gun in hand. It was only for an instant that we saw the whale as we steamed past at a high rate of speed. But the captains were alert. There were two loud reports that almost deafened us, and that made the boat tremble from stem to stern. The whale gave a sweep of his flukes through the air as the bombs exploded, and rolled over dead."

Captain Cogan, who carried out this boat, in his report regarding its work the first year, said that it was "used to advantage towing boats to windward and towing whales to ship in light winds. Found her most useful in chasing wounded whales that got loose. It is hard for a whale to get away from her in open water, and she always got fast second boat. We used the darting gun, hand lance, and bomb lances. We got two whales with her, and saved one wounded whale that we would have lost if we did not have her... . Used properly, one steam launch is a big advantage to a ship." 


\section{$\mathrm{X}$ \\ SKETCHES AFLOAT WITH THE WHALERS}

HAT the original deep-water whaling ves-
sels were manned by the men who had
built and owned them has already been noted. On the return of such a ship to port the crew received lays or shares, in proportion to the work each had done, and then the remainder of the catch was divided in proportion to the share each owned in the ship. When oil was at its lowest such a crew could live by their fishing, and when it was high they might grow rich. The energetic and ambitious poor man never had a better chance to get on in the world than in the early days of the American whale fishery. Naturally the ambitious poor flocked to the whaling ports, and the population of those ports grew in more ways than one with the growth of the fishery. Thus the ships were then supplied with excellent 
crews. Later it was necessary for the captains to reach out to the near-by towns to complete their crews.

"Captain Isaiah West, now eighty-six years of age, tells me that he remembers when he picked his crew within a radius of sixty miles of New Bedford; that oftentimes he was acquainted, either personally or through report, with the social standing or business standing and qualifications of every man on his vessel, and also that he remembers the first foreigner, an Irishman, that shipped with him, the circumstance being commented upon at thàt time as being a remarkable one." (James Templeman Brown.)

Later still neither the whaling ports nor the near-by towns could furnish men, and the whaler captains perforce applied to the crimps (men who made a business of supplying crews to ships) of all the Atlantic ports for men. They sailed short-handed and touched at the Azores or the Cape de Verdes for Portuguese sailors, all of whom were whalers accustomed to an alongshore fishery. They reached down on the coast of Africa and gathered whom they could find, such 
246 The Story of the New England Whalers

as the marooned crews of slavers and other outcasts of the earth. In the Pacific they stopped at the Islands and recruited among the beach combers, - white degenerates who preferred life among the cannibal islanders, but were willing to make a voyage now and then.

In the columns of the New York Sun, on July I4, I839, appeared the following advertisements:

"Wanted immediately, Ioo enterprising young men, Americans, to go on whaling voyages in first-rate ships. Carpenters, coopers, and blacksmiths also wanted. The present is a very desirable opportunity for those who wish to take a voyage to sea to learn navigation or nautical improvement. All clothing and other necessary articles furnished on credit. Apply to S. \& J. N. Luckey, Io6 South Street, upstairs."

"Wanted, thirty young men for the three ships at New Bedford, twenty-five men for two ships at Fairhaven, twelve men for a ship at New London, ten men for a ship at Sag Harbor. By applying immediately at Thomas Lewis' clothing store, No. I 5 James Slip, they can have their choice of ships and places. All clothing furnished on credit." 
It was an advertisement something like one of those that drew to the sea J. Ross Brown, whose Etchings of a Whaling Cruise was once a "bestseller" among sea stories. He had grown tired of the work of a Washington reporter, and on coming to New York thought to see the world from the deck of a whale ship.

"You think we'll do?" he asked timidly after he and a companion had applied to a crimp.

"Oh, no doubt about it," replied the crimp. "I'm willing to risk you though I may lose something by it. If you are determined to make a voyage, I'll put you in the way of shipping in a most elegant vessel, well fitted, - that's the great wellfitted Vigilana, and activity will insure your rapid promotion. I haven't the last doubt but you will come home boat steerers. I sent off six college students a few days ago, and a poor fellow who had been flogged away from home by a vicious wife. A whaler, gentlemen, - a whaler is a place of refuge for the distressed and persecuted, a school for the dissipated, an asylum for the needy. There's nothing like it. You can see the world - you can see something of life." 
248 The Story of the New England Whalers

In this way the "greenhorns" were tolled to the ship. Like Frank Bullen in later years, Brown signed for the voyage although he had no idea of what he was to receive or where he was going.

When the crew had been gathered they were taken to the ship, and she was usually found at anchor well out in the bay, lest some of the men desert as soon as they learned her destination. In the early days it was the custom among New Bedford owners, at least, to go on board the departing whalers with a company of friends and give the ship "a send-off" by sailing down the bay in her, and serve all hands with a fine dinner and something to drink. But that would never do in later days. The anchor was got up as soon as possible after the crew came on board. No one of the whaler writers speaks of singing a "chanty" at the windlass, but Melville says in Moby Dick that as the Pequod reached out to sea "lank Bildad as pilot headed the first watch and ever and anon as the old craft deep dived into the green seas, and sent the shivering frost all over her, and the winds howled and the cordage rang, his steady notes were heard: 
"Sweet fields beyond the swelling flood, Stand dressed in living green, So to the Jews old Canaan stood, While Jordan rolled between."

The first work on every whaler, after reaching open water, was the training of the raw hands. Some whaler captains allowed them to rest in the forecastle until the inevitable seasickness had worn off, but as a rule they had to work it off. Bullen says of his first evening on a whaler:

"Seven stalwart men were being compelled to march up and down on that tumbling deck, men who had never before trodden anything less solid than the earth. The third mate, a waspish, spiteful little Yankee, with a face like an angry cat, strolled about among them, a strand of rope yarns in his hand, which he wielded constantly, regardless of where he struck a man. They fell about, sometimes four at once, and his blows flew thick and fast, yet he never seemed to weary of his ill doing.... Such brutality I never witnessed before." The next day, however, "in spite of their treatment, perbaps because of it, some of the poor fellows were beginning to take hold of things man fashion." 
250 The Story of the New England Whalers

While one of the mates trained the "greenhorns," the men who could do a sailor's work rigged the crows' nests, - little platforms on which a man could stand high up above the sails on each mast. Seats were fitted on some of these platforms, and all were provided with stout hoops within which the lookout could stand safely. On each mast two men were usually kept throughout each day, on the lookout for whales, and their eyesight was sharpened by an offer of ten pounds of tobacco, sometimes five dollars, as a reward to the one who first announced a whale that the crew succeeded in saving.

The boats were also prepared for service. In each were placed three or four harpoons, two lances, a boat spade, a short-handled axe or two, and a stout knife or two. The harpoon lines were carefully coiled into the tubs which were put into the boats. The oars and the mast and sails were laid in ready for instant use and then a keg of water and one of bread, a lantern with candles, a bucket for dipping, a dipper for the same purpose, and a small flag for signalling were added. In modern boats, at least one gun is carried with sufficient ammunition. 
The crews were divided into two divisions called watches, - "starboard" and "larboard." "Starboard" and "port" are the designations on ordinary merchantmen. The mates also picked crews for their boats, four men for each, each mate picking a man in turn, beginning with the first mate.

As soon as the boats were ready and the weather would serve, the ship was hove to, - a part of her sails were placed so that the wind would prevent her going ahead, - and then the boats were lowered to teach the crews how to row. A log was sometimes allowed to drift at the end of a line, and the boats were rowed close to it in order that the inexperienced might have a chance to throw dummy harpoons at it. In these drills the ambitious youngsters of the old days took part with an eager zest that soon made them whalemen; but the landsmen who had been "bamboozled" on board, and the merchant sailor who had shipped through a misunderstanding, always looked upon them with disgust.

If lucky, additional drill was had when a school of "blackfish" appeared. These small whales 
252 The Story of the New England Whalers

did not yield much oil, but the chase was more realistic than rowing aimlessly around the ship and harpooning a log. Moreover, the flesh of these whales is very good eating, and fresh meat is a treat at sea.

Meals were served at 7:30 A.M., at noon, and at 5 P.м. Meat, usually boiled, and bread were dumped in bulk into pans and carried from the galley, or cook room, to the forecastle, where the men divided it and ate it from small pans. For drink they had tea and coffee sweetened with "longlick" - molasses. On the better class of ships the cooks made scouse, a mixture of hardtack (soaked in water) and meat; or of beans, hardtack, and meat; or potatoes, hardtack, and meat. The memory of scouse whets the appetite of every old sailor long after he leaves the sea. Duff was a mixture of flour, lard, and some kind of cheap fruit, such as dried apples. The mixture was boiled in a bag and then served with molasses. "Plum duff" was stuffed with raisins - and served in the cabin. The meat of blackfish and porpoises was often boiled with "doughboys," or dumplings that were not afflicted with any- 
thing to make them light, but they were always eaten with avidity. The men ate their food sitting on benches in front of their bunks in the forecastle. Young gentlemen accustomed to table elegancies found forecastle conversation and eating habits deplorable at times, until custom had changed their habits of thought.

Finally a day came when a lookout saw the spout of a whale, or the form of a whale breeching, or the tail of a whale lashing the water, and straightway he roused the ship by bawling:

"There she b-l-o-w-s! Blows! B-l-o-w-s! There she breeches! There she white-waters!"

The crews hurried to their boats and the captain climbed to the main crow's nest. The ship was headed for the whale, the "pod," or the "school," as the case might be, and then when the captain thought her near enough, he ordered the boats away. The mate in each boat took the steering oar, and the harpooner the bow oar. The lightest man in the crew had the stroke oar and also attended the sheet of the mainsail. His oar was formerly 12 or I4 feet long, but may now be no more than 9. The oarsman forward of the 
254 The Story of the New England Whalers

stroke had charge of the line tub and pulled a heavy oar, - I 2 to 16 feet long. The next oarsman had a still longer oar, - formerly as much as I8 feet long, - while the man forward of him, who was called the bow oarsman, had a shorter oar and was required to attend to stepping the mast and taking it down. The harpooner, called boat steerer usually, pulled a light oar. The mate steered the boat with an oar from 19 to 22 feet long. The long oars formerly used went out of fashion because it was found that they wore out the men in any but the shortest pulls.

With sail alone in a good wind, with oars and sail in a light wind, and with oars alone in light airs and up wind, the boats headed away for the whale. When approaching under oars the men put them away, and took paddles as they drew near the whale. The ship was usually left in charge of the captain, the cook, the cooper, and an idler or two. If the captain "lowered," the cooper was ship keeper.

The wildest boat races the world ever saw were those made in chase of whales by boats from rival ships, - especially from ships of different nation- 
alities. With English, French, Portuguese, and Americans pulling for one whale, every man worked with all his might for the honor of the flag; and that is a fact worth considering. In one racethe story is a classic among American whalemen - an English and an American boat chased a whale in Delagoa Bay. The Englishmen were able to cut in between the whale and the American boat, but as they drew up beside the whale, and the Englishman at the bow reached for his iron, the American harpooner leaped to his feet and "pitchpoled" his harpoon clear over the English boat and struck the whale.

To "pitchpole" is to throw a harpoon with both hands through a high curve to a long range. In "pitchpoling" the harpooner generally rests the top end of the harpoon handle in the palm of his right hand and then, steadying the weapon with the left hand, gives it a toss.

As the harpoon in the Delagoa Bay race struck the whale, the harpoon line fell across the English boat. The English crew were placed in deadly peril, but they managed to get clear of the line before a strain came upon it. Then the Ameri- 
256 The Story of the New England Whalers

cans went on and killed the whale. The writer has been unable to find an account of any race in which Americans were beaten; apparently beaten Yankees were too much ashamed of themselves to record their experiences.

To the "greenhorn" the row to the whale was often a period of painful terror.

"Y'r a smart youngster, an' I've kinder took to yer," said the mate to Frank Bullen as he pulled toward his first whale; "but don't ye look ahead and get gallied, 'r I'll knock ye stiff wi' th' tiller; ye hear me? An' don't ye dare to make thet sheet fast, 'r ye'll die so sudden y' won't know where y'r hurted."

It was a necessary warning, for green hands have been known to jump overboard in a panic on finding themselves alongside a whale. By sailing as well as rowing, Bullen's boat reached the whale.

“'Stand up, Louey!' said the mate softly. . . . Suddenly there was a bump; at the same moment the mate yelled, 'Give 't to him! Give 't to him!' and to me, 'Haul that main sheet, naow haul, why don't ye ?' I hauled it flat aft and the boat 
shot up into the wind, rubbing sides as she did so with what, to my troubled sight, seemed an enormous mass of black india rubber floating."

The whale up tail and sounded. The men made haste to take down the mast with its sails and stow the bundle aft by sticking the heel of the mast under the afterthwart and allowing twothirds of the bundle to project beyond the stern of the boat. The mate went forward and the harpooner came aft and took up the steering oar, thus becoming the boat steerer and earning the name by which he was known on the ship.

As the line ran out, the boat steerer threw turns around the post standing in the stern until the strain made the bow of the boat plunge down to the water's edge while the stern rose high. It was in this manner that whales were usually struck.

The custom under which the boat steerer struck the whale and then went aft, while the mate went forward to lance the whale, seemed to be foolish and dangerous to Herman Melville. He thought the mate should both strike and lance the whale. As the whalers saw the matter, however, the most 
$25^{8}$ The Story of the New England Whalers

experienced man was needed at the steering oar until the whale was struck, and then he was needed at the lance. Moreover, placing a man of less experience at the harpoon gave him a good training. Young men of agility were often promoted to the rank of harpooner during their first voyage. Bullen was promoted still higher - he became fourth mate. The ambitious youth could have his chance at all times in the whale fishery, even in ships commanded by hard men, indeed, perhaps sooner in them than in others.

Of the incidents and accidents that have followed the striking of whales, so many extraordinary stories have been told that one comes to think that the extraordinary is the ordinary event, if such an expression may be allowed. It is interesting to note, too, that in nearly every story of the kind some one of the boat's crew appears in the character of hero. Consider as an example a tale told of Amos C. Baker, who was third mate of the bark Awashonks in 1864, and afterward for many years keeper of Clark's Point lighthouse, near New Bedford. On October I3 of the year mentioned, the Awashonks raised two 
whales off the coast of Patagonia. Three boats were lowered, including that of Mr. Baker, and they took the whales head and head. The mate got fast first, and then Mr. Baker, after a vain effort to reach the other whale, pulled in where his harpooner threw two irons into the mate's whale. In the usual course Mr. Baker then went forward and used his lance, but at the instant he shoved the steel home the whale caught his boat with its tail, and the next thing Baker knew he was lying in a half of the boat. The other half had been reduced to splinters, and one of Baker's legs had been broken above the knee. After saving the whale (Baker's lance thrust killed it) the other boat took the young man to the ship, where he lay in his bunk for eighty days. When at last he was able to walk on crutches, he happened to be on deck when a whale was raised. All the boats having been ordered away, Baker took his place in spite of the remonstrances of the other officers, and leaning on the heavy steering oar in place of a crutch, he put his boat where his harpooner was able to give the whale first iron. Among the classic tales of the whale fishery is 
260 The Story of the New England Whalers that of the loss of the Ann Alexander, of New Bedford. This ship was on the "Offshore Grounds" - west of Chili and Peru - when on August 20, 1850, a "pod" of whales appeared and three boats were lowered, Captain John S. Deblois going in one of them. The mate's boat soon struck one of the "pod," but the monster instantly turned with jaws open and the men fled overboard just in time to save their lives. A moment later the whale bit the boat to pieces. Such a disaster as this, though shocking enough to a "greenhorn," was a common experience among the whalemen. Captain Deblois at once pulled in, picked up the boat's crew, and shifted a part of them to the second mate's boat. Then both the captain and the second mate started to attack the whale, which had been busy, meantime, biting at the pieces of the boat it had destroyed. In the usual course a whale thus engaged would not have noticed the approach of the boats for a second attack; but this one had its eyes open, and it turned to meet the enemy more than halfway. Rushing forward with a speed and agility that no boat could escape, it grasped the second 
mate's boat, as it had that of the mate, and literally bit it into kindling wood.

Captain Deblois was a fighting man; the fact that he had gone afloat where it was the whaler custom for a captain to remain on the ship and allow the mates to do the fighting, proves that he was a man of aggressive courage. But when he had once more picked his men from the sea (they had escaped as before by jumping overboard), he headed for the ship, and when there he sent the mate to gather up the oars and such other débris as might have escaped the fury of the whale. In his view it was his duty to fill his ship with oil, and not to "whale for glory," as persistence in fighting a whale of this kind was sometimes called.

The mate, however, was of more reckless disposition. He gathered the débris as ordered, and then, when returning to the ship, managed to get within range of the whale and thrust a lance into it. Unfortunately, however, he failed to reach a vital point, and the whale, ignoring the small boat, made a dash at the ship, striking her abreast the foremast and crushing in her side. She sank so rapidly that the crew were unable to secure 
262 The Story of the New England Whalers

more than three gallons of water, and they would have perished speedily in their open boats but for the fact that they were picked up by another whale ship.

Of course whale-ship owners always cautioned their officers not to do such reckless things; they all said that needless risks were to be avoided; but the fact was that if the mate had succeeded when he made that last attack he would have sailed on his next voyage as a shipmaster, and very well he knew it.

Memorable in a different way was Captain Sparks, of the Provincetown whaling schooner Edward Lee. During the afternoon of May I4, I88I, Captain Sparks and his mate lowered their boats in pursuit of whales. By good luck and good work the mate soon killed one which he secured alongside the schooner and then began the usual work of cutting in the blubber. Captain Sparks went after a whale that was shy, and it led him such a race that when he at last gave up all hope of securing it, and tried to find his way back, he was, through some error of his own or upon the schooner, unable to do so. 
Captain Sparks and his men were adrift in the torrid zone, a thousand miles from land, in an open boat twenty-eight feet long. The keg of water which they had taken with them when leaving the ship had been emptied before the pursuit of the whale was abandoned. For six days they sailed toward the land with no food nor any water except a little saved during rain squalls. Then a school of whales appeared. To the mind of any ordinary whaler, knowing, as all do, the ugly disposition of the bulls usually found with such schools as this was, the whales were to be avoided by a crew in the condition of Captain Sparks and his men. To the captain, however, they seemed to offer a chance for life, and he and his men, rising superior to the weakness that weighed them down, pulled into the school and killed a whale that they might eat its flesh. Later they were picked up and brought to land.

In a Diary of a Whaling Cruise, by Victor Slocum, published in the Forest and Stream, in December, 1907, is a story that describes a not uncommon experience of the whalemen after striking a whale. It says : 
264 The Story of the New England Whalers

"We jumped the boat ahead and darted two irons, which started him off at a high speed to windward, and the people on the ship told us afterward that we literally skipped from one sea to the next. All we were conscious of was the fact that the boat simply rested on her keel and the spray flew over us in great sheets.

"At last he slacked up and gave us a chance to put in a bomb lance. He made a rush to leeward, to where we had left the dead whale,straight as a die and right over him, - dragging us over, too, of course, all the time spouting blood. Then he dove under us and came up with his blow-hole right under the nose of the mate, who was looking over the side for him, and he got the spout of thick blood right in the face at less than a yard distance. Of course it spattered all of us, and when we hauled alongside with our two whales we all looked as much like murderers as anything else."

More men lost their lives through the flying harpoon line than in any other way. As the sounding whale dragged out the line a coil very often caught around a man's body or limb and 
carried him down. Cases where a man was taken down so swiftly that the crew did not see it done are on record. Sometimes the line jammed in the crotch in the bow of the boat and carried boat and all down. Sometimes the whale came to the surface, striking the bottom of the boat through accident. Men were kicked overboard by the bomb-throwing guns. Bullen suffered this mishap, and then, in trying to save himself, he unwittingly dragged himself up on top of the whale he had shot just as it was going into its death flurry. He managed to cling to the harpoon during the flurry, but was laid up for three weeks after he was rescued.

An interesting story of a whale boat lost from a ship is that told by Captain Roland F. Coffin in An Old Sailor's Yarns. Coffin was in the captain's boat, and the captain held on to a whale that ran away all one night. They killed the whale in the morning, "waifed" it, and then started to sail back and find the ship.

"We missed the ship some way. Arter runnin' till noon the next day and seein' nothin' of her, the old man made up his mind that we had run 
266 The Story of the New England Whalers

by her; that she was a-workin' up to windward to look for us, and had reached so far over our track as to be out of our sight when we passed her. 'So,'says he, ' 'tain't no use to run off any further, and 'tain't no use pullin' to windward, and the best thing we can do is jist to lay still, and she'll cruise about till she finds us.'

"Well, we laid still for twenty-four hours longer, and then our grub was very near all used up, and things was a-lookin' bad for us; so we set sail and concluded we'd reach back and forth on a wind, and we done so . . . till near six o'clock, when just as we was a-goin' round one of the chaps who had stood up for to git a good look sings out 'Land ho!' Up we all jumped in a jiffy, and there, sure enough, about two p'ints on the lee bow, was a small island."

They landed on the island at daylight the next morning. It was one of the coral reefs common to certain parts of the Pacific, and one not found on the charts.

"What we wanted jist then more than anythin' else was somethin' for to drink. We hadn't had no water for nearly twenty-four hours. You may 
jist imagine, then, how glad we was when one of the party by the name of Tom Bunker - he belonged to Nantucket - sung out, 'Here's a spring!' You see, sir, there was six of us all told, and the old man had made us separate as far apart as we could and yet be within hail, and so go across the island for to survey it like and try for to find wood and water. At Tom's hail, hows'ever, we all come to at once and ranged up to him, and sure enough, here was a little spring of beautiful clear water. If you want to know what first-class tipple is you must try spring water arter you've been in a boat twenty-four hours without any. Tom told us that afore he come up with the spring he seen the whole ground alive with some kind of creepin' animal, but what they was he couldn't tell. Well, we didn't hyst that in exactly, but we thought that maybe Tom's bein' so long on the water without anythin' for to drink had made him kind of loony, and so he imagined he seen animals when he hadn't. 'What's funny about this here island,' says the old man, 'is that there ain't no birds onto it. I've landed on plenty of islands afore which didn't 
268 The Story of the New England Whalers

have no natives onto 'em, and there was always thousands of birds; and here, exceptin' some gulls a-flyin' over the reef, we ain't seen a bird.'

"'Talkin' about inhabitants,' says one of the chaps, just then, 'what do you call that thing yonder?' We looked where he p'inted and there, sure enough, was a native. He appeared for to be kind of frightened at us, and kept at a respectful distance, and as we advanced he retreated. So the old man, he says, 'You stay here, my lads, and I'll go for'ard alone, and then maybe it won't be so much afeerd.' So we sits down and the old man he goes on ahead, puttin' his hands onto his breast, and a-makin' all sort of motions for to show that he didn't mean no harm; and finally the savage seemed to understand, and stopped still for to let our old man come up. But it seemed, as he told us arterward, when he got within hailin' distance, all of a sudden the native, as we had took it to be, runned toward him, and with a kind of a yell like jist tumbled down all into a bunch at his feet. Well, we heerd the yell the critter grave, and we rushed up to where the old man was, and if ever I see a man flabbergasted completely, 
it was that old man. 'Boys,' says he, 'that ain't no native; it's a woman and a white woman at that; and how on earth she got here beats me entirely.'

"Well, she soon come around to herself, and if ever you see a critter delighted for to see anybody that there critter was delighted for to see us. And the first words she said when she come to was: 'It ain't no dream; you are real. Thank God, I am saved!'

"'Well, as to that, marm,' says our old man, 'of course we'll do anythin' for you that's in our power; but whether you be saved or not, there's different opinions about, but there ain't no doubt of the fact that we are lost." ",

The lone woman was the wife of the captain of a whale ship that had been lost with all hands except her on the reef. She had been washed ashore and then had managed to save enough from the wreck to make herself comfortable so far as living was concerned, and there she had remained for five years.

"Well, it was a good job for us, anyway. When we got to her hut she says to our old man, 'Now 
270 The Story of the New England Whalers

you and your men sit down here behind the house, and I'll go to work for to cook you a breakfast. Of course I didn't expect company, and so I haven't got none ready at present; but there's plenty here and I won't be long a-gittin' of it.' Well, she takes a stick that looked somethin' like a boat's tiller and away she went into the grove of cocoanuts, and we seen her a-runnin' back and forth a-strikin' at somethin' on the ground, but whatever it was we didn't know, and to tell the truth we didn't care. Fact was we was all pretty well tuckered out, and gittin' where all things was comfortable and a good breakfast promised us, we jist give up and stretched down onto the grass and went to sleep. The old man sot the example, and I heerd him a-borin' pump$\log$ afore I dropped off. I was woke up by one of the finest smells of cookin' I ever smelt, and it fetched me right up onto my feet to onct, and I went along to where the woman had her fire, - jist some stones with a fire built onto 'em, - and found that what I smelt come from a big sasspan which she had over the fire. 'Wait a few minits,' says she; 'it's a'most done; and if 
you don't say it's a good stew, then call me a bad cook.' The smell had waked up the rest of the chaps by this time, and we was all ready for our meal when she dished it up. Well, sir, I never eat anything like that stew in all my born days. I s'pose it was because I was hungry, partly, but then it really was extremely nice as she made it, for we had it often after that when we wasn't so sharp set.

"The woman she looked on quite delighted for to see us eat, and a-fillin' each chap's dish as fast as it was empty; but arter she had helped us all around for the sixth time ... says she, 'I'll bet you don't any of you know what you've been eatin'.'

"'Well, marm,' said our skipper, 'that 'ere was jist the question I was a-goin' for to ask you; this here's a powerful good stew, and shows that you're a fust-class cook, - but that of course you would be, comin' from Nantucket, - but I hain't seen no birds onto the island, and I can't jist judge from the taste what sort of a animal you've made it of.'

"'Well,' says she, 'that there was a rat stew, 
272 The Story of the New England Whalers

and rats is now about the only livin' thing there is upon the island except ourselves, and I begun to think that if they increased much more they'd eat me as they have everythin' else.'"

The rats had come from the wrecked ship, "the numerous eggs in the birds' nests provin' a great temptation," and they had driven the birds from the reef. They had then begun to clear the cocoanut trees, and the lost sailors found themselves face to face with the problem of controlling the increase of the rats under penalty of starvation. But while they were working at the problem in sailor fashion - "we had rat to eat all ways, roast rat, broiled rat, fried rat, rat fricassee, and rat stew" - the ship to which they belonged arrived off the island and took them away, leaving the rats in full control.

In the usual course, after a whale had been harpooned it sounded and then, on returning to the surface, went swimming away as if in search of a far country. The crew then faced forward and grasping the line hauled in and pulled the boat closer to the whale, if possible. If the speed of the whale was so great they could 
not do this, they waited until the whale became tired and slackened speed, say from ten or twelve knots down to five or six. As the boat was then hauled near it was steered out around the thrashing tail. The mate sometimes reached out forward of the bow of the boat, clutched the line, drew it aft by main strength, and handed the bight to the bow oarsman, who held it, leaving the mate free. If the harpoon was planted well forward, it was not necessary to do this. In any way possible the boat was drawn up until the mate, standing in the bow, was able to reach out with the lance and drive it into the vitals of the whale.

To this day the old hand lances are used in open water, for who would throw away a fivedollar bomb when the hand lance would serve?

Having killed the whale the carcass was usually towed to the ship, though it often happened that the ship could be sailed to the carcass. Towing a whale was the hardest work known to the sea; for nothing wilts a man like plying the oars when he cannot see that the boat is making any progress.

Right whales very often sank as soon as dead, and sperm whales did so sometimes. In her 


\section{The Story of the New England Whalers}

first voyage the Charles Phelps saved five sperm whales and twenty-nine right whales. Ten others were killed, only to have them sink. The lines parted when six others were struck (an unusual proportion, showing that she had cheap warp), and from twelve that were struck the irons drew out, showing that she did not carry toggle-irons. Her record was that of the average of her day.

In shoal waters like those of the Okhotsk Sea, sunken whales were sometimes buoyed and watched until the gases of decomposition brought them to the surface. A special harpoon was invented for raising sunken whales from shoal depths. This harpoon had enormous barbs and it was of extraordinary weight, - made so with cast iron. It was fitted with rings that, when slipped over the taut-drawn harpoon line which had gone down with the dead whale, would serve as guides or fair-leaders to keep the instrument pointed at the whale as it dropped down through the water. Such a harpoon, sliding down the warp, would often sink into the carcass and hold there until the stout line that was always fastened to it could be wound around the ship's windlass, 
and lift the carcass to the surface "like a speared sucker," as a whaleman said to the writer.

Sometimes a boat abandoned, for the time, a whale that it had killed in order to pursue another near at hand. When two whales were killed by one boat's crew they sometimes left one afloat where it died while they towed the other to the ship. In every whale left adrift the men planted a signal flag called the "waif." The "waif" was to guide the searchers who always went after the carcass.

When the boats were lowered, the men remaining on the ship kept a careful lookout, watching the whales and the boats. If the whales were not instantly found by the boats' crews, these lookouts signalled the location of the whale by waving a flag kept at the masthead for that purpose, and by manipulating the sails in various ways. Every ship had its own private code of signals for such occasions, and the display, when the boats of several ships were following one whale, was sometimes wildly exciting.

After towing a dead whale to the ship the crew secured it alongside by means of a chain that 
276 The Story of the New England Whalers

was looped around the "small" and then taken in through a port in the bow of the ship and made fast to a stout timber-head provided for the purpose. By keeping the ship under easy sail the body of the whale floated close alongside. A staging or scaffold was rigged out from the side of the ship in such a way that the body of the whale floated between it and the ship, and yet at some distance below it. On this staging the first and the second mates usually worked with spades - chisels with handles from twelve to twenty feet long - to cut the blubber from the carcass. A stout railing on the side next to the ship was provided, and against this the officers leaned as they worked at the whale. Two huge tackles were suspended from aloft and a "blubber hook" at the bottom of one of these was inserted into a hole that was cut into the whale between the eye and the fin. When this had been done the whale's head was cut off and allowed to float, at the end of a stout line, astern of the ship while the blubber was stripped in a long spiral from the body. In stripping the blubber the men hoisted away on the tackle that had been hooked into the 


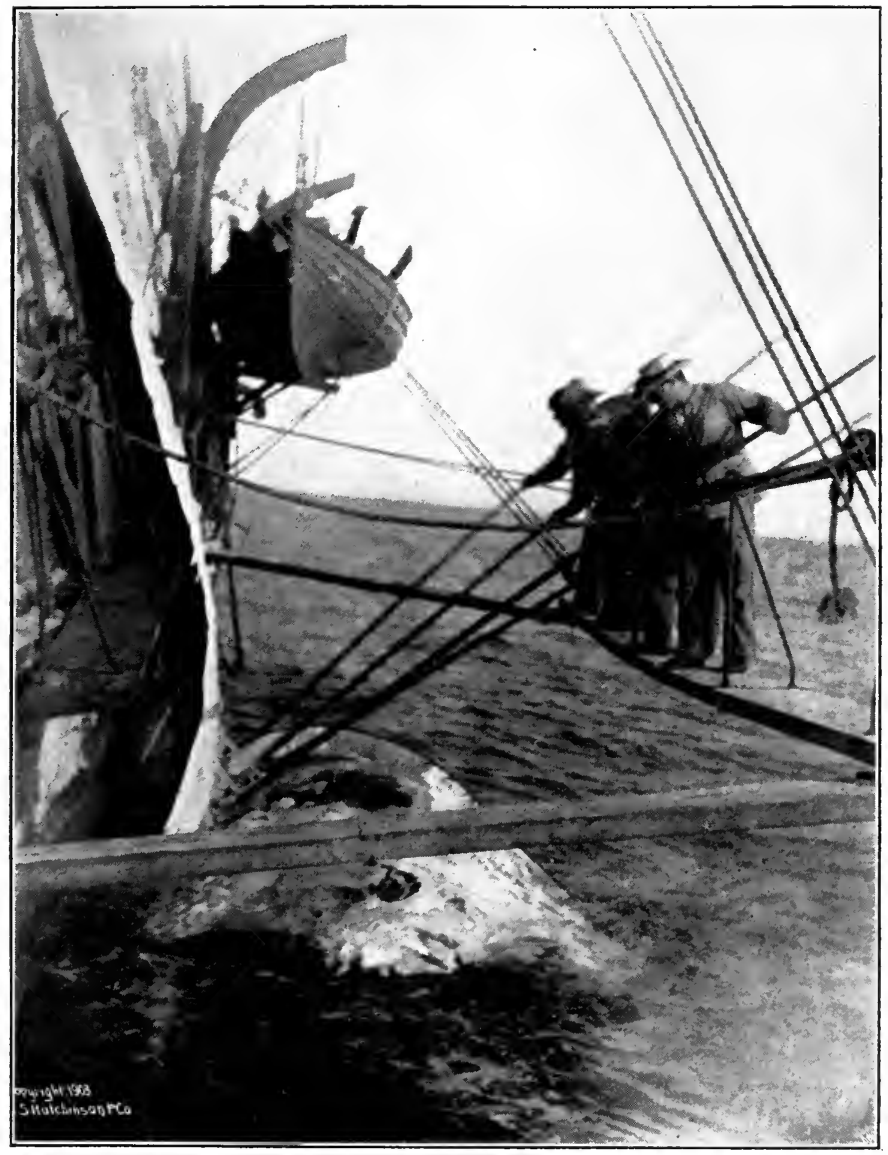

Cutting in a Whale 

blubber near the eye, and the officers cut through the blubber in such a way as to release a long strip. When the tackle had been run up as high as possible another one was hooked into the blubber at the level of the scaffolding and then the part above this tackle was cut loose with a longhandled, long-bladed knife, called a boarding knife. The big pieces of blubber thus secured were called blanket pieces, and they were from three to six feet wide by perhaps twenty feet long. They were lowered into the hold as fast as secured, until the body was stripped.' The head was then cared for. The head of the sperm whale was peculiar. The lower jaw was long and slender. The part above the mouth was composed of a tough gristle called "white-horse." Above that was a boneless layer of blubber called the "junk," and above that a huge cell-really a great tank - that was filled with a superior quality of oil in a liquid condition. The entire head of a small sperm whale was hoisted in on deck and there cut up. The lower jaw of a large sperm whale was taken in first of all; then the "white-horse" and "junk" were separated and 
278 The Story of the New England Whalers

hoisted, each by itself, on deck. The "case," as the huge tank in the head was called, was then hoisted in if possible; if too heavy for that, the case was hoisted, neck end up, as high out of water as possible, after which a hole was opened into the tank, or case, and the oil was bailed out with a bucket.

In cutting up the heads of the bone whale, it was customary to cut off the lips, which were full of oil, and then take pains to get on deck the upper jaw with the bone attached.

When the more valuable parts of the whale were on the ship, the lean carcass was allowed to go adrift, - food for the sharks that always swarmed around a whale ship that was "cutting in." The fact is that the sharks sometimes got so much of the blubber that the crew were kept busy to save any quantity worth while, and this was especially true when three or more whales were brought alongside at once, as sometimes happened. It is said that the sharks never attacked the men who, in the course of the work, were obliged to get down on the whale's body. Nevertheless, the officers on the cutting stage 
usually jabbed their spades into every shark that came within reach, because of the quantity of blubber taken. Killing or wounding a shark always attracted the near-by sharks to it, and it was devoured by them.

The blanket pieces of blubber were cut into chunks as large as a man could handle - each say as long as the blanket was wide, and a foot or so wide. These were laid one at a time on benches called "horses" and slices were cut, something like the slices from a loaf of bread, only the slice was not quite severed from the main chunk. As these slices were connected together, something like the leaves of a book, they were called "books" and "bibles." The "books" of blubber were pitched into the try-pots, which were huge iron kettles, two or three in number, supported in a brick furnace placed on deck abaft the foremast. An iron pan full of water was placed under the furnace as a precaution against fire. The furnace was heated by burning "scrap," the fibrous remainder left after the oil was extracted from the blubber. When a ship returned home, it always carried enough scrap to start 
280 The Story of the New England Whalers

the fires on the next voyage: As the oil came from the blubber, it was dipped into tanks to cool and then run into the barrels and stowed in the hold.

Steam whalers have been fitted with tanks heated by steam to try out the oil. In the Norwegian fishery the lean parts of the whale are steamed to extract the oil, and the refuse is made into fertilizer.

At all times, cutting in a whale was hard work. It was work that had to be done as rapidly as possible, too. Trying out the blubber was not so hard, though on a ship where the master was overbearing and cruel it could be made most disagreeable.

Slocum, previously quoted, says of the work: "Cutting in and trying out the blubber is a prosy job, and nasty is no name for it. All hands strip down to a shirt [he was in a warm-water whale ship], a pair of overalls rolled up to the knees, showing a pair of bare shins and sockless feet in large brogans, and in we go-grease from head to foot-day and night until the whale is all cut safely on board. It gives you 
a funny sensation at first to get into a deckful of blubber, with the slimy stuff around your exposed cuticle, and oil squashing out of your shoes at every step."

As a rule, the men found some pleasure in dipping their hardtack into the boiling oil, and thus recooking it into a sea dainty. The flesh of the young whales was eaten, especially that of the humpback. In some ships a barrel of flour was brought on deck and the cook was kept busy making doughnuts while the boiling was in hand. Sailors from ships commanded by the strong men of the fishery - men who did not feel obliged to resort to cruelty to preserve discipline - always spoke of boiling out the oil as a "squantum," which is the Nantucket word for a picnic, and they were known to call the boat ride which was taken when a struck whale towed the boat far from the ship a "Nantucket sleigh ride."

In foul weather no master could make the work of cutting in anything less than a terrible hardship, especially if the ship were in high latitudes. And the boiling, which had to be done on deck without shelter, was of course also a hardship. 
282 The Story of the New England Whalers

The bark fava, that sailed from New Bedford on October 2, 1872 , carried a donkey engine on deck for use in all hoisting work, and especially when cutting in. The modern steam whalers have steam winches for the same purpose.

"Scrimshawing" and "gamming" alone remain to be considered in the life of whaler crews. "Gamming" was simply visiting from ship to ship whenever opportunity offered. A boat from each of two ships meeting in fair weather would be lowered to carry parties to and fro. It was a hard ship indeed where the crew was not allowed such a bit of recreation, and the men who thus got together told stories, sang, and danced to their hearts' content. "Scrimshawing" was the work of the whaler artists. In all but the worst ships the men were allowed at least half of each twenty-four-hour day to themselves. On some ships they had more than half. This leisure was allowed, of course, only when there was no whale in sight or alongside. The men could not sleep all of their watches below and there were no circulating or other libraries on whale ships. To pass away the 
heavy hours, the men made many kinds of fancy things for friends at home. The teeth of the sperm whales were saved and carved into picture frames, brackets, and many other devices. Canes were made from the sperm jawbone, from whalebone, and from the backbones of a shark strung on an iron rod. The heads of these canes were generally carved from teeth of the sperm whale. Strange woods were secured at the islands where the ship called, and these were made into writingtables, work-stands, work-boxes, etc., and they were often inlaid with tooth ivory and shells and woods of different colors, making designs of striking beauty. Strange fibres were woven into mats and rugs. The tools used by the "scrimshanders," as these workers were called, were usually as rude as those used by the aborigines, but, like the aborigines, the sailors had no end of time, and a look into the parlors of the oldtime whalers shows that artists were developed among the men who killed whales for a living; the product of their skill was really the expression of the love they had for the work they were doing. 
284 The Story of the New England Whalers

Said a writer in Hunt's Merchants' Magazine, November, 1840 :

"The appearance of most whalemen when they return from a voyage is hardy and robust in the extreme; the substantial food and bracing air, afforded by the circumstances in which they are placed, as well as their violent exercise, serving to give remarkable vigor and animation to their constitution. The class of men acting in the capacity of masters cannot be regarded with too great respect. As a body they are men who have combined in their character the most valuable traits; cool, determined, and brave, they bear the weight of duties and encounter hazards which could hardly be appreciated upon the land. A striking difference exists, however, in the success of different masters. Some appear always endowed with good luck, while others are as uniformly unfortunate in their expeditions. Doubtless the different success of these captains may be attributable to a diversity in skill, energy, knowledge, and prudence; yet it is often owing to circumstances which are known only to the Omniscient. We have in our eye one of these 
men who, although yet comparatively young, is distinguished for his energy and his uniform success. Spare in his form, there is a restlessness in his eye and frame which seems to indicate that his soul is absorbed in his pursuit and conquered by his ambition to succeed. ... He has worked his way by degrees to the station of principal owner in a large ship, starting as he did a common sailor, and by his own efforts has already earned a considerable fortune. ... This man has been a source of vast profit to his employers, and while we are writing is probably hurling the harpoon into a whale upon waves so high and beneath clouds so dark that other mariners would deem it prudent to lay to for preservation from the winds."

The whalemen were the frontiersmen of the sea. Their life was at least as rude and as dangerous as that of the home makers who built $\log$ huts between the villages of hostile savages in the West. And on the whale ship as on the frontier, the man who had ambition and energy and endurance always won out at last. 


\section{XI}

\section{WORK OF THE FIGHTING WHALES}

CAID Captain Benjamin Worth in writing 1 his autobiography for use in Macy's History of Nantucket:

"I began to follow the sea in 1783 , being then fifteen years of age, and continued until I824. During this period of forty-one years I was shipmaster twenty-nine years. From the time when I commenced going to sea until I quitted the business I was at home only seven years. At the rate of four miles an hour while at sea I have sailed more than I,I9I,000 miles. ... I have assisted in obtaining 20,000 barrels of oil. . . While I commanded a vessel not one of my crew was killed or even had a limb broken by a whale."

It sometimes happened that way. Some captains loaded their ships, voyage after voyage, with never a mishap of any kind, but in the usual course the whalemen had fierce combats with whales during every cruise. Among the many 
stories told of the fighting whales none is more graphic than that related by J. T. Brown in Stray Leaves from a Whaler's Log (as printed in the Century Magazine for February, 1893), about the death of a Portuguese-American boat steerer known as Vera.

"Vera had been ordered to rig up one of the spare boats; and devoted most of his night to strapping irons and getting his boat into shape for lowering, whistling and humming snatches of songs to himself as he worked industriously about the windlass bitts. Early the next morning a lone sperm whale was descried on the horizon, and the larboard and bow boats were again ordered down.

"'I think you'd better play loose boats to-day, and let Mr. Ashford get fast,' said the captain to Mr. Braxton [the mate in charge of the larboard boat, Mr. Ashford, the third mate, having command of the bow boat] as the boats pulled away from the ship.

" All right, sir,' replied the mate, and away sped the boats through the silent water under double motive power of sail and oar. 
288 The Story of the New England Whalers

"The bow boat, according to orders, got in first, but the whale turned flukes and sounded. Both boats lay off for the rising, and for further developments. The boat steerer of the bow boat had been reported ill before leaving the vessel, and Vera had taken his place.... The stroke oarsman [of the larboard boat - it was Brown, the writer] was retained at his own oar, and at the time we now speak of was in excellent position to witness the magnificent spectacle of harpooning a large sperm whale, provided Mr. Ashford's boat should strike it first.

"Vera was standing in the bow of his boat with his harpoon well in hand, his head swathed in a party-colored handkerchief, his shirt collar turned well back, exposing the bronze of his powerful neck, and his nervous, restless eye covering the sea about him. There was a deathlike stillness about the scene, broken only by the swashing of the restless waves as they beat against the sides of the boats, and by the gurgling noise of the tide-rips as they played mischievously with the steering oars which trailed astern.

"Suddenly there seemed to be a commotion in 
the bow boat, Vera uttered a cry in Portuguese, and, like a terrific bolt of fire from the clear sky of a midsummer day, the immense, glistening lower jaw, armed with two rows of polished teeth, flashed from the water, and the gigantic whale leaped into the air, carrying with it the head of the boat, which had been snapped asunder, and the unfortunate Vera, whose head and long arms were suspended from the corner of the monster's mouth, the body and legs being confined within the iron vice. The sportive humpbacks, those clowns of the cetaceous order, oftentimes bolt clear of the water; but it is seldom the horizon is outlined between a sperm whale and the sea. The eyes of the stroke oarsman of the larboard boat were directed to poor Vera's face, - the rapidly changing expression of that face, which afterwards appeared to him in his dreams in the forecastle and in his lonely vigils at night. First it indicated surprise and indignation; next it seemed to implore help; but the lips spake not and not a muscle moved. A calm resignation now settled upon the blanched features, but it soon gave way to utter despair and help- 
290 The Story of the New England Whalers

lessness, which were rapidly succeeded by facial contortions indicative of the most intense physical suffering. The whale closed its mouth upon the victim's waist, and disappeared beneath the boiling waters, carrying with it the wretched sufferer, whose life blood tinged the foam-crested waves.

"Two other men, the bow oarsman and the mịdship oarsman, were never seen again. No one knows whether they were killed outright or drowned. The remaining three, all more or less cut or bruised, though not seriously, were fished up from the floating débris, the officer, Mr. Ashford, being hauled up by the hair of his head in a fainting condition. Not a word was uttered except by Mr. Braxton, who said in a low, soft tone of voice:

"'Come, boys, let's head her for the ship."”

Some of the stories of the fighting whales indicate that when an old sperm had been attacked and had escaped serious injury he was always ready thereafter to force the fighting at sight of a whale boat. For example, consider the story of the Barclay, Captain William Barney, Jr., 
of Nantucket. She sailed for the Pacific on October 9, 1832. The story of her adventures was mever told in detail, but before the end of the month, while off the Azores, she sent her boats after a sperm whale, and the mate's boat soon struck it with both irons. When the mate had gone forward to apply the lance, however, the whale turned and killed him, after which it made good its escape. A few days later the ship Hector, Captain John O. Morse, of New Bedford, met the same whale. Captain. Morse was one of the fighting skippers and lowered with his mates for the attack, only to find that the whale was coming to meet them all at least halfway. It selected the mate's boat for its first rush. The mate by a quick turn escaped its first attack and managed to throw a harpoon into it as it passed; but the next instant the whale struck the boat, no one knows how, and made basket work of its bow.

The whale then turned, apparently to attack the boat with its jaw, and it would have gone hard with the crippled boat but for the presence of the captain, who pulled in and attracted the 
292 The Story of the New England Whalers

attention of the monster. As the whale turned toward the captain's boat the mate shouted:

"Look out, sir; it's a fighting whale!"

"All right; I've got a long lance and want to try it," replied the captain. But before he had poised his boasted lance the whale grabbed the boat by the bow, lifted it entirely out of the water and shook it to pieces, scattering the crew and implements far and wide over the water. The crew were all picked up, leaving the whale busily searching the water for fragments of the broken boat. These, as he found them, were all bitten and crushed into matchwood, save only a keg that had been in the boat. That danced over the waves, escaping the rushes of the whale in a way that seemed to exasperate the monster; at any rate, it soon left all other objects to pursue the keg with steadily growing vigor.

On seeing, after reaching the ship, the whale's interest in the keg, the mate (his name was Norton, but his first name was not recorded) offered to pick a crew and lower once more. He was allowed to do so. As he drew near to the whale, however, it lost interest in the keg 
and turned on the boat with such vicious dashes that the crew literally fled for life. For half a mile they pulled and turned and backed water with all their might. Several times they escaped from the snapping jaws by less than a foot, and they were rapidly reaching a condition where they could not make another stroke of the oar when the whale suddenly turned over (it had been fighting as sperm whales usually do with its belly up), in order to get its nose out of water and inhale a breath of fresh air.

As it happened, the boat was at that moment within easy reach, and Mr. Norton, who had never for a moment lost his head, was able to drive his lance into the "life," killing it almost instantly. On cutting in the blubber the harpoons from the Barclay were found in its body, thus proving beyond dispute that it was the whale that had killed the Barclay's mate.

The stories of the ability of the fighting whales to endure punishment are almost beyond belief. The bark Emerald, Captain Abraham Pierce, that sailed from New Bedford on July 15, r857, fell in with a fighting whale in the North Pacific 
294 The Story of the New England Whalers

that kept all her boats busy for nine hours. During that time it was struck by five harpoons, and seven bombs were exploded in it; yet it destroyed three boats, meantime, and then, when it was at last killed, it sank in forty fathoms of water and the crew got nothing for their labor.

More extraordinary still was the experience of Captain Malloy, of the Osceola 3d, of New Bedford. The waist boat and the captain's boat were lowered for a lone bull. Both struck the whale, which in turn stove in both of the boats. A sweep of its tail cut the bottom out of the captain's boat; the other boat was merely crushed. The waist boat, in the meantime, had fired a bomb into the whale, but without any effect whatever, so far as the men could see.

As all hands had been thrown into the water by the attack of the whale, the ship had to come and pick them up. When this had been done Captain Malloy headed the ship toward the whale and stood, gun in hand, ready to fire a bomb as soon as a convenient range should be reached. It was supposed that the whale would be so busy crushing the fragments of the broken boats that 
it would not heed the approach of the ship. Nevertheless, as soon as he saw the ship coming (it was when she was about three hundred feet away) the whale turned on its side and made for the ship, with its mouth open, as is the habit of the species in making an attack. The whale struck the vessel on the bluff of the bow, knocking off the cutwater. The ship trembled from stem to stern, and so great was the concussion that many articles on board, such as crockery and glassware, were dislodged from the places where they were usually kept. As the whale crossed the bow two hand lances and a bomb were thrown into it. The vessel was headed for the whale the second time, but it kept off. All this time the two tow lines and a portion of the stove boat were fastened to the whale, the lines being entangled about its body. Captain Malloy with a picked crew finally approached the whale and killed it after a desperate battle of twelve hours. (The Whale Fishery.)

Starbuck says that thirty-one bombs were fired into this whale before it was killed. It yielded II 5 barrels of oil. 
296 The Story of the New England Whalers

Davis, in his Nimrod of the Sea, tells about the work of another fighting whale which made such a terrific onslaught upon the boats that the crew of the ship were entirely demoralized, and the captain felt obliged to make port in order to give the men a chance to run away, - a privilege of which they availed themselves promptly.

Right whales also fight back, though but rarely. A Long Island captain, whose name is not given, relates a story of a fight with one of these whales (it can be found in Starbuck's history) that seems well worth quoting verbatim:

"My second mate had fastened to a large whale that seemed disposed to be ugly; so I pulled up and fastened to her also. I went into the bow and darted my lance, but the whale rolled so that I missed the life and struck into the shoulder blade. It pierced so deep into the bone (perhaps through it) that I could not draw it out; the whole body of the whale shivered and squirmed as if in great pain. Then turning a little, she cut her flukes, taking the boat amidships. The broadside was stove in, and the boat rolled over, the crew having jumped into the sea. I cut the line 
in the chocks at the same moment to save being run under with a kink. The crew were soon safely housed on the bottom of the upturned boat, or swimming and clinging to the keel. The second mate wanted to cut his line and pick us up, but I foolishly told him to hold on and kill the whale. But I bragged too soon. Just then the whale came on the full breach, and striking the boat he went right through it, knocking men and wreck high in the air. Next its great bulk fell over sideways, right in our midst, and spitefully cut the corners of her flukes right and left. In the surge and confusion two poor fellows went down; we saw no sign of them afterward, and the water was so dark - stained with blood - that we could not see into it.

"As the whale came feeling around with her nose she passed close by me. I was afraid of the flukes and got hold of the warp or something and towed a little way until she slacked speed a little. Then I dove under, so as to clear the flukes, and came up astern of them. I was in good time, for having felt the boat she turned over and threshed it with a number of blows 
298 The Story of the New England Whalers

in quick succession, pounding the wreck into splinters. She must have caught sight of me, for she came up on a half breach and dropped her head on me, and drove me, half stunned, deep into the water. Again I came up near the small, and again dove under the flukes. From this time she seemed to keep me in sight. Again and again she would run her head in the air and fall on my back, bruising and half drowning me as I was driven down in the water.

"Sometimes I caught hold of the line or something attached to the mad brute, and would hold until a sweep of the flukes would take my legs and break my hold. The second mate's boat had cut long ago, and watched her chance to pick up the surviving crew, but had not been able to reach me; for when the whale's eye caught the boat she would dash for it so wickedly that the whole crew became demoralized. . . . To husband my strength I gave over swimming, and, treading water, I faced the danger and several times by sinking avoiding the blow from her head. As a desperate resource, I strove with the point of my sheath knife to prick her nose. ... Thus 
for three-quarters of an hour that whale and I were fighting; the act of breathing became labored and painful; my head and shoulders were sore from bruises and my legs had been pounded by her flukes; but it was not until I found myself swimming with my arms alone, with my legs hanging paralyzed, that I felt actually scared. Then it looked as if I couldn't hold out much longer. I had seen the ship close beside me and the second mate's boat trying to get in to me and throwing me lines; but I had failed to reach them. Now these things seemed very far off; that was the last I remembered until I came to aboard ship.

"I was afterward told that the first mate, in answer to a signal from the ship, had come up; and seeing me feebly paddling with my hands and not answering his hail he put straight into the fight. The whale saw them coming and made for them. The men sprang to their oars, and the mate had time to seize my collar while they pulled their best to escape the furious whale.

"The mate had true pluck. Leaving me to the care of the crew on board, he put back for 
300 The Story of the New England Whalers

the whale. As he afterward said, 'she was too dangerous a cuss to run at large in that pasture field.' Watching a chance he got a set on her over the shoulder blade and sent the red flag into the air. This tamed her; she lagged around for a time and settled away dead. The mate then came on board and reported sunk whale. It was several weeks before I was able to take my place in the head of my boat again."

Still more remarkable than these stories are those of the whales that left off fighting the small boats to make a deliberate attack upon the ship from which they had come. Many ships have collided with whales and many whales have struck ships with destructive effect through pure accident, because unable to see what is directly ahead of them; but the interest in this chapter is confined to the fighting qualities of the monsters.

Of the stories of the ships that have been struck by whales making a deliberate attack, the most noted were those of the loss of the $A n n$ Alexander, already told, and of the sinking of the Essex, of Nantucket.

The bark Katblene, Captain Thomas H. Jen- 
kins, of New Bedford, was sunk by a whale a little north of the equator in the Atlantic, on March 7, 1902, and the newspapers of the day wrote an account of the disaster in which it was said that the attack by the whale was premeditated. The facts, as related by Captain Jenkins in a book printed in New Bedford during the same year, show that when the whale had arrived near the ship it plunged down and tried to go under the ship, but he was so near and was coming so fast he did not have room enough to get clear of her. Another ship, the Pocabontas, of Holmes Hole, was attacked by a whale that left off fighting her boats and made a dash at her. It struck a glancing blow on the bow that opened several of her plank ends. She put into Rio Janeiro, leaking at the rate of 250 strokes of the pump per hour.

In addition to what has already been said about the loss of the Ann Alexander, it may be worth telling that five months after the disaster the Rebecca Sims, of New Bedford, killed the whale that had sunk the unfortunate ship, as was proved by finding the irons which the men of the $A n n$ 
302 The Story of the New England Whalers

Alexander had thrown into it, together with several pieces of timber that had been embedded in its head when it broke in the side of the ship. The injuries thus sustained had tamed its spirit, and it made no fight when struck by the Sims.

The Essex sailed from Nantucket on August I2, I8I9, under the command of Captain George Pollard, Jr., who, by the way, was already somewhat distinguished through having been one of the crew of Fulton's Clermont in her first voyage up the Hudson. The Essex followed the usual course around the Horn, and when, on November 20, she was in latitude $0^{\circ} 4 \mathrm{O}^{\prime}$ south and longitude I $19^{\circ}$ west, whales were raised. Three boats were lowered. The mate's boat got an iron into a whale, but at the next instant the animal struck the boat with its tail, and opened a hole so large that the mate was obliged to cut the warp immediately. By stuffing their clothes into the hole the crew of the boat managed to keep it afloat while they pulled back to the ship for repairs.

On reaching the ship the mate saw that the captain and the second mate were fast to a whale, and he headed the ship down toward them. 
Then, as he was about to begin the work of repairing his own boat, the mate saw a huge sperm whale come to the surface of the water about twenty rods away. It lay for a moment apparently having a look at the ship, and then it settled just beneath the surface, after the manner of whales when making an attack, and headed for the ship. The mate ordered the wheel hard up, but the ship was moving so slowly that she was unable to dodge, and the whale struck her on the bow, giving her "such an appalling and tremendous jar as nearly threw us all on our faces. The ship brought up as suddenly and violently as if she had struck a rock," so said the mate. The whale then passed under the ship, scraping her keel as he passed, and came to the surface about a hundred yards away, where he lay thrashing the water with his tail and "snapping his jaws as if in a great fury."

Meantime the ship began to sink, and the mate (Mr. Owen Chase, who wrote an account of the disaster that was printed in book form) at once started the pumps and set a signal to recall the boats. A little later, as he was getting some 
304 The Story of the New England Whalers

provisions ready to put in the boats, one of the crew shouted:

"Here he is; he is making for us again!"

"I turned around and saw him about a hundred rods directly ahead of us," wrote Mr. Chase, "coming down with apparently twice his ordinary speed, and to me it appeared with tenfold fury and vengeance in his aspect. The surf flew in all directions and his course toward us was marked by a white foam of a rod in width, which he made with a continual violent thrashing of his tail. His head was about half, out of water, and in that way he came upon and again struck the ship. I called out to the helmsman, 'Hard up!' but she had not fallen off more than a point when we took the second shock. I should judge the speed of the ship to have been at this time about three knots and that of the whale about six. He struck her to windward, directly under the cathead, and completely stove in her bows. $\mathrm{He}$ passed under the ship again, went off to leeward, and we saw no more of him."

The spare boat was now hurriedly launched overboard and the ship's compasses were put into 


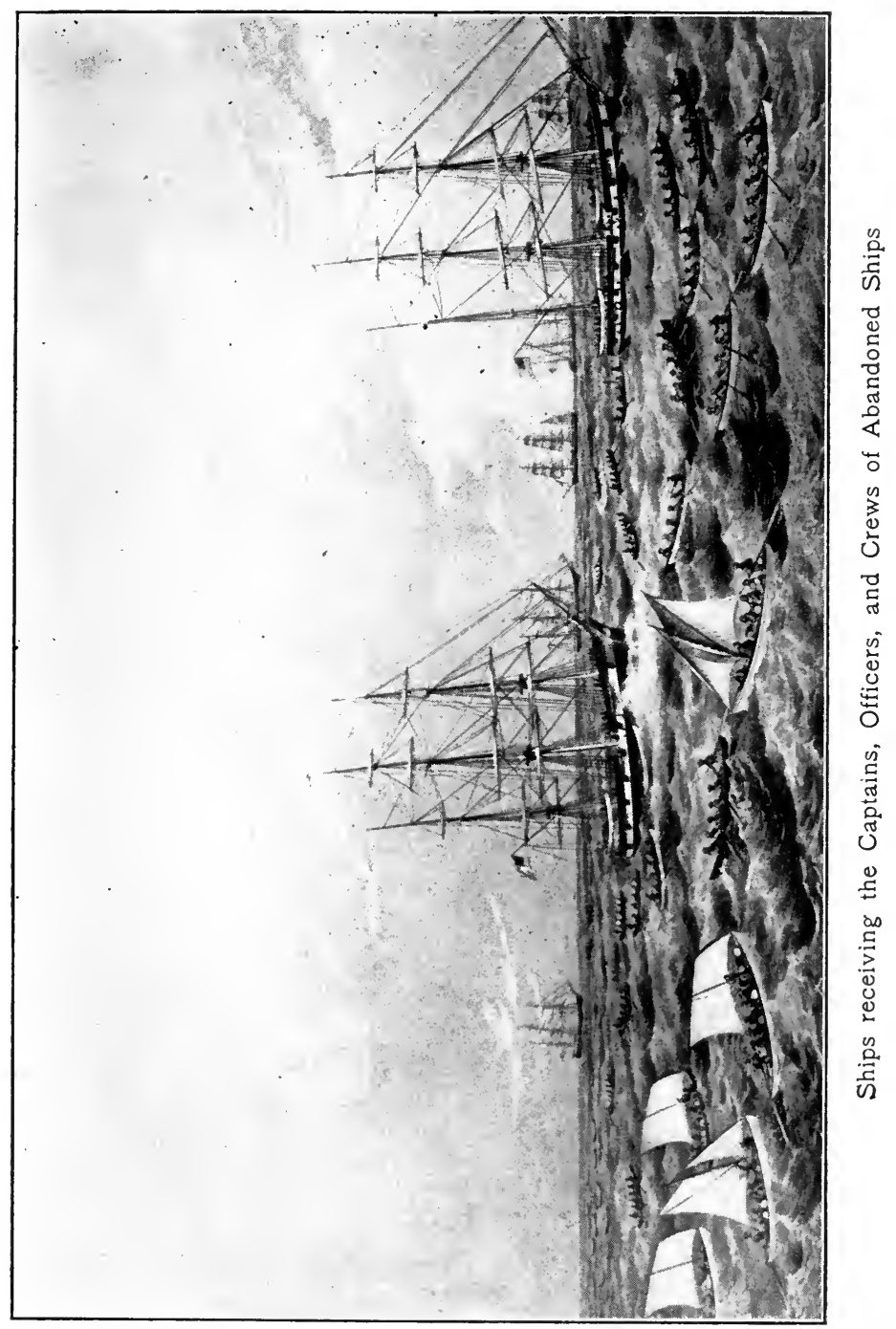



it. When the other boats that had been in pursuit of the whales returned to the ship, the captain cut away her masts. Thus relieved, she sank more slowly, and the crew were able to get from her 600 pounds of bread, 200 gallons of water, a musket, a small canister of powder, two files, two rasps, two pounds of boat nails, and some meat. Each boat was fitted with a jib and two spritsails, and while lying beside the ship, which remained for some time afloat with her deck awash, the sides of the three boats were built up with spare plank so that they would be less likely to ship water in a gale. Finally a consultation was held. The nearest land was the Marquesas Islands, and next to them the Society Islands. But the crew feared to head for those islands because in those days the natives were savages who had not been well treated by such ships as had visited them. Accordingly it was determined, on November 22, to steer for the coast of South America.

One of the boats (that commanded by the mate) was old and patched, having been knocked partly to pieces several times in fights with whales. 
306 The Story of the New England Whalers

To it only six men were assigned. The other two carried seven men each. It was agreed that the daily allowance of each man should be one hard biscuit and a half pint of water. It was while thinking of the condition of himself and shipmates as they thus began their passage toward the mainland that Mr. Chase wrote:

"The dark ocean and swelling waters were nothing; the fears of being swallowed up by some dreadful tempest, or dashed upon hidden rocks, with all the other ordinary subjects of fearful contemplation, seemed scarcely entitled to a moment's thought; the dismal-looking wreck and the horrid aspect and revenge of the whale wholly engrossed my reflections until day again made its appearance."

On December 16 the allowance of food and water was reduced one-half. To quench their thirst the men then began going overboard to soak in moisture, as they supposed, and in doing this they discovered a number of barnacles on the bottoms of the boats. These they cleaned off and devoured. Four days later land was seen, Ducie's Island. 
On landing a cave was discovered near the beach, and it was immediately examined. Lying on the floor the searchers found eight human skeletons, and a board in which had been cut with a sailor's knife the words, "Ship Elizibeth of London."

As the island afforded water, with a little peppergrass, and as it was possible to catch fish on the reef, three of the castaways determined to remain in spite of the manifest fate that had overtaken the men from the Elizabeth. The others renewed their supply of water and sailed away once more.

In a storm on January 12,1820 , the mate's boat was separated from the other two. Two days later, when he had been away from the island about two weeks, Mr. Chase wrote in his diary (as published; it was, of course, a muchedited diary, for no whaleman was ever guilty of using such language):

"We were as yet just able to move about in our boat and slowly perform the necessary labors appertaining to her; but we were fast wasting away with the relaxing effects of the water, and 
308 The Story of the New England Whalers we daily almost perished under the torrid rays of a meridian sun; to escape which we would lie down in the bottom of the boat, cover ourselves with the sails, and abandon her to the mercy of the waves. Upon attempting to rise again the blood would rush into the head and an intoxicating blindness come over us."

Six days later still, he said: "We were hardly able to crawl about the boat. Our ounce and a half of bread, which was to serve us all day, was in some cases greedily devoured, as if life was to continue but another moment; and at other times it was hoarded up and eaten crumb by crumb, at regular intervals during the day, as if it was to last forever."

To add to their misery, the men usually dreamed of eating at tables loaded with food.

On February 8 one of the men, Isaac Cole, suddenly leaped to his feet, hoisted the jib, shouted that he would not give up, and that he would live as long as any of them. Then he fell down and died. Chase told the survivors that they ought to use the body for food.

"We separated his limbs from his body and 


\section{Work of the Fighting Whales}

cut all the flesh from the bones; after which we opened the body, took out the heart, and then closed it up again, sewed it up as decently as we could, and committed it to the sea. We now first commenced to satisfy the immediate cravings of nature from the heart; after which we hung up the remainder, cut in thin strips, about the boat to dry in the sun; we made a fire and roasted some of it to serve us during the next day."

They lived on the flesh of the dead man until the morning of the 18 th, when at 7 o'clock one of the men shouted, "Sail ho!" It was no delusion; the brig Indian, of London, was at hand. She picked them up and carried them to Valparaiso. They had reached latitude $33^{\circ} 45^{\prime}$ and longitude $81^{\circ} 3^{\prime}$. The Indian arrived at Valparaiso on February 25 .

The captain's boat and that of the second mate were together until January 28. Their provisions were exhausted and three men died of starvation. The flesh of these men was divided between the two boats and eaten. On February I the men in the captain's boat, being once more without food, drew lots to see who should die 
310 The Story of the New England Whalers

and who should be the executioner. Owen Coffin drew the death lot and Charles Ramsdale the other. When the lot had fallen, the captain begged Ramsdale to kill him instead of Coffin, who was Pollard's cousin; but Coffin refused to permit this to be done. Coffin's flesh was eaten. On February I I Barzilla Ray died of exhaustion, leaving Pollard and Ramsdale alone in the boat. They were found in a delirium by the whale ship Dauphin, which arrived with them at Valparaiso on March 17. The boat of the second mate was never heard from. The men left on Ducie's Island endured terrible suffering, but were rescued by a British vessel before life was gone.

"The story of the Essex's loss and of the dire necessity to which the survivors were reduced, preceded Captain Pollard to Nantucket. Eyewitnesses of the scene on his return say that the cliffs and wharves were lined with spectators, and that he walked to his home through an awestruck, silent crowd." (Gustav Kobbé, in Century Magazine.)

Pollard sailed in command of the ship $T_{\text {wo }}$ Brothers in $182 \mathrm{I}$, but she was lost on a coral 


\section{Work of the Fighting Whales}

reef in the Pacific, and the captain, although all hands were saved, gave up the sea. He was for many years on the police force at Nantucket, and died there in 1870 , aged eighty-one years. Owen Chase became a successful whaler captain. 


\section{XII}

WHALING AS A BUSINESS ENTERPRISE

$7 \mathrm{HE}$ counting-house hero of the American whale fishery was a man who deliberately took his life in his hand in the hope of making a large profit, and succeeded. His name was Captain W. T. Walker, of New Bedford.

In 1847 Captain William C. Brownell, of New Bedford, bought an old ship named the Envoy, intending to break her up for the metal in her hull. In her career the Envoy had always been a lucky ship. She was built in the booming year of 1833 for Amherst Everett, of Providence, and she was registered at 392 tons, the size of the ordinary Pacific whaler of her day. She sailed from home December 26, in the year she was built, under Captain J. C. Clark, and she returned four years later - January I, I838with 2100 barrels of sperm oil, worth $\$ 57,887$. And that is to say, her first cruise paid for the 
cost of ship and outfit, and left a large sum as clean profit in addition. In her last cruise, which ended in February, I847, she brought home a cargo worth $\$ 56,000$, and in the meantime she had done so well that she had cleared well up toward $\$ 200,000$ for her fortunate owner, or say $\$ 12,000$ a year during the fourteen years, on an original investment of perhaps $\$ 35,000$ all told.

But now the ship was far gone, worn out in "bucking" the gales off Cape Horn, and the ice beyond Bering's Strait. Captain Everett was rich enough to retire from whaling and the ship was sold, as said, to the owner of a "nautical bone yard."

When the Envoy reached New Bedford, however, Captain W. T. Walker took a look at her. Captain Walker wanted a ship. During a previous voyage he had purchased on speculation, at Wytootacke, a thousand barrels of oil that had been saved from a wreck, and he wanted a ship, first of all, to carry that oil to market. In addition to the freighting venture, however, he also wished to try whaling again. The Envoy was certainly a hard-looking specimen of a ship, but Captain 
3I4 The Story of the New England Whalers

Walker thought she would last for one more cruise. He was willing to "take a chance," at any rate. And when he offered to take her, it was not in the nature of any owner to refuse to fit her out.

All told, including the ship, the expense of a few repairs, and the outfit of food and whaling apparatus, the Envoy cost just $\$ 8000$, when ready for sea. Application was then made for "a good fat lump of insurance, to cover the risk on the way," but the underwriters without exception asked to be excused. This refusal of the insurance companies to risk a dollar at any premium shows to a seafaring man better than anything else the condition of the old hulk, and it was the entire willingness of Captain Walker to sail on a ship as rotten as she was that makes him the chief counting-house hero of the fishery.

There is, of course, another point of view. $\mathrm{He}$ was risking not only his own life but the lives of his crew, and it is certain that not one of the forecastle men had any idea of the risk he was taking when he signed for the voyage. To ship a crew in a rotten ship was never considered 


\section{Whaling as a Business Enterprise 315}

reprehensible among shipowners, and that is a fact of some importance, perhaps, in any account of any branch of sea commerce.

The Envoy sailed from New Bedford on July I4, 1848. Going to Wytootacke, she carried Captain Walker's oil to Manila, whence it was shipped to London, and sold at a profit of $\$ 9000$. Then the Envoy went cruising, and in fifty-five days took 2800 barrels of whale oil besides bone. Returning to Manila, Captain Walker shipped 1800 barrels of the oil and 40,000 pounds of the bone to London, where it was sold at a net profit of $\$ 37,500$. Meantime on going for another cruise Walker had the extraordinary luck to secure 2500 barrels of whale oil and 35,000 pounds of bone.

As the old ship was now loaded in every nook and hollow, Captain Walker headed for San Francisco, where he arrived in $185 \mathrm{I}$. Here oil and bone were sold to the value of $\$ 73,45^{\circ}$; bone that netted $\$ 12,500$ was shipped to New. Bedford, and then, to end all, he sold the ship for $\$ 6000$. On an investment of $\$ 8000$ the Envoy made $\$ 138,450$.

The records show that as early as 1616 - in 
316 The Story of the New England Whalers

the days of Champlain and Hudson - whale oil was exported from New England. Most of this oil was probably obtained from whales that floated dead to the beach, for the early court records are full of troubles arising from opposing claimants to such whales. Nevertheless the people of every settlement alongshore were prepared to go afloat in pursuit of whales seen from the beach, and it is interesting to note that the people of Salem, for going as far as Cape Cod in search of whales, were counted extraordinarily venturesome. Of the profits made on Massachusetts Bay and Long Island by the alongshore whalers in the early days, no definite record exists. The records of Nantucket are more satisfactory. Thus, in 1715 six sloops that averaged $3^{8}$ tons in size secured 600 barrels of oil and I I,000 pounds of bone, the value of the whole being $£$ I roo. At first thought this seems a small take for a year's work of six sloops, but it must be remembered that these sloops were not constantly at sea; the owners, who were also the crews, were, as already noted, farmers who worked their land besides going whaling. They, at least, produced their 


\section{Whaling as a Business Enterprise}

own food between cruises. Moreover, in that era of low wages $£ 183$ per vessel seemed vastly larger than such a sum seems now. In 1730 twenty-five vessels secured 3700 barrels of oil, and in 1745 the island shipped 10,000 barrels of oil to Boston alone. Small as the average income of a ship may seem, the business was growing. Further than that, the vessels did not fare all alike. Some came home "clean," - without a barrel of oil, while others saved large quantities in short periods. Naturally, the good luck of the few kept the many trying.

Two interesting business facts are related of the fishery in those early days. In 1706 one Thomas Houghton secured from the New York authorities a monopoly of the lean parts of whales, which, in the usual course of the fishery, were left at the water's edge to decay. He set forth in his petition to the authorities that he intended to carry the meat and bones to Boston, where he was to treat the material by a secret process. What the product was to be is not stated, but it appears by inference that he was to make saltpetre by burying the material in the soil, where, 
318 The Story of the New England Whalers

as is now known, the nitrate of potash would be formed by bacterial processes.

In $175^{\circ}$ an Englishman, named Benjamin Crabb, obtained from the Massachusetts authorities a monopoly for making sperm candles during a period of fourteen years. The Crabb monopoly failed. No capitalistic monopoly of the early days ever succeeded, though backed by legal enactment, as have the monopolies of modern days which have, in some cases, been maintained contrary to statute.

The extent of the whaling business in the years before the Revolution has been set forth in figures. Large as was the business then done by Nantucket, the extent of the fishery at other ports was of small moment. After the American seamen, by good fighting afloat during the War of 1812 , had secured the right to cross all seas unmolested by foreigners, the business spread to other ports rapidly. Thus in 1815 the total number of whalers that went to sea after peace was restored was: from Nantucket, 50; from New Bedford, I0; from Sag Harbor, Long Island, 3; from Fairhaven, Massachusetts, 2; from Hudson, New 
Whaling as a Business Enterprise

York, 2, and from Westport, Massachusetts, I. While fourteen of these ships returned to port "clean," more than half of them brought home full cargoes, and it was in 1817 , when those of the fleet which had gone to the Pacific were coming into port, that the recorded catch of sperm for the first time rose above 1,000,000 gallons, the actual amount being $1,028,475$, worth 72 cents a gallon. The take of whale oil was 561,830 , which then sold for 60 cents, and this, with 19,444 pounds of bone that sold for 12 cents a pound (it was hardly worth saving at the price), brought the total income of the whalers for that year up to $\$ 1,091,576.88$.

Fewer ships had been fitted for the fishery in 1816 and 1817 than in 1815 , but the success of the Pacific ships that arrived in 1817 started a growth of the fishery which continued practically unchecked for about thirty years.

A curious feature of this growth was the interest taken by capitalists in out-of-the-way ports. Two ships sailed from Hudson in 1817 , following those of 1815 to the Pacific, and one, the Eliza Baker, Captain Paddock, was long remembered 


\section{The Story of the New England Whalers}

because she was overhauled by a pirate that robbed her crew of all the clothing they had. In I8I8 Philadelphia tried whaling with indifferent success. A year later New York City sent out two. Perth Amboy tried the fishery in 1824; Edenton, North Carolina, in 1831; Poughkeepsie, in 1832; while Gloucester, Massachusetts, the home of the cod-fishery, turned to whaling in 1833. The next year Newburgh, New York, joined the whaling fleet, and Portland and Wiscasset, Maine, came in during the same year. If one may judge by the-names of the captains of these outport ships, the business was started in them by migrants from old Nantucket and New Bedford, just as ship-building was undertaken on the Ohio River by migrants from Massachusetts. For the outport captains were usually Coffins, or Starbucks, or Husseys, or Paddocks, or others with names familiar on the island.

The increase in the number of whaling ports (there were 32 all told in 1835) was indicative of the growth of the fishery. Prices were gradually increasing, while the enterprising shipmasters were going farther afield and discovering new 
grounds where whales were numerous and not easily frightened. In 1835 the whalers brought home 5,181,529 gallons of sperm oil, which sold at 84 cents. The take of whale oil was $3,950,289$ gallons, which sold at 39 cents. This was less than the price of 1817 , but, in the meantime, the price of whalebone had increased to $2 \mathrm{I}$ cents a pound, and the take was nearly a million pounds. Two years later the take of whale oil passed that of sperm, $-6,385,995$ to $5,319,138$ gallons.

In 1829 the American whaling fleet numbered 203 vessels; in 1834,421 ; in 1840,552 . In 1846 there were 680 ships and barks, 34 brigs, and 22 schooners, a total of 736 vessels, hunting for whales under the American flag. That was the flood-tide year for the number of vessels. The fleet measured 233,262 tons, and the estimated investment was $\$ 21,000,000$, or say $\$ 28$, 000 per vessel. It is certain that this estimate is high enough, for shipowners have always had the habit of appreciating their own possessions. New London owned the largest ship of the fleet, the Atlantic, measuring 699 tons, and the smallest as well, the schooner Garland, of 49 tons, that was at work on the coasts of Desolation Island. 
322 The Story of the New England Whalers

While many outports had entered the trade, the principal part of the growth of the fleet had been in Buzzard's Bay. In 1822 Nantucket sent 40 whalers to sea; New Bedford sent 33. In the next year Nantucket sent 19 and New Bedford 26, - the sceptre had departed from Nantucket forever. Though no people ever loved home better than did the inhabitants of Nantucket, the inconveniences of a shallow harbor compelled them to move. New Bedford was, at an early date, the port of chief importance on the mainland, and the refining business increased there with greater rapidity than at Nantucket, because Nantucket owners had found it convenient to carry their oil to Buzzard's Bay, even while they fitted their ships at their home port. Moreover, New Bedford's whale fishery had been built up, as noted; by men who, for various reasons, had emigrated from Nantucket in the days before the shoal water on Nantucket bar had become a crying evil.

Being a growing port, New Bedford naturally benefited by the ups and downs of the fishery at the outports. The merchants who made the 
sporadic ventures elsewhere and succeeded were often glad to sell out and retire; those who failed retired perforce, and in each case New Bedford was ready with the cash to buy the ships.

The fishery reached high water in Buzzard's Bay in 1857, when New Bedford owned 329 whale ships, and those owned at the other ports of the bay, including Fairhaven, Dartmouth, Westport, Mattapoisett, and Sippican, brought the Bay fleet up to 426 vessels. New London, Connecticut, and Sag Harbor, Long Island, were considerable ports. They sent seventeen and thirteen vessels to sea in the "boom" year of 1846 .

In 1835 the value of the product of the whalers exceeded for the first time $\$ 6,000,000$. In 1845 the sperm-whale fishery reached its highest point in amount of product, the total import being $4,967,55^{\circ}$ gallons. The price was then 88 cents a gallon. In $\mathrm{I} 855$ the price was $\$$ I. 772 per gallon, but the amount saved was only 2,288,443 gallons. Whale oil reached record figures in 1840 , when the take was II, 593,483 gallons. The price, then 33 cents, rose above 73 in 1855 ; but the amount then saved was only $5,796,472$ gallons. 
324 The Story of the New England Whalers

In 1853 the product of bone reached $5,652,300$, the record amount. The price was then $34 \frac{1}{2}$ cents; it had been 50 during the year before. The highest income received by the whalers in any one year was in 1854, when the take sold for $\$ 10,802,594 \cdot 20$. That was therefore the floodtide year of the fishery. The catch of 1857 sold for $\$ 10,491,548.90$, and the years 1853 to 1857 , inclusive, paid the whalers $\$ 51,063,659.59$. The catch of each year sold for about $5^{\circ}$ per cent of the estimated investment in the fleet.

In the year after the Superior showed the way to the fishery north of Bering's Strait, I54 ships entered those waters. Starbuck estimates that this fleet was worth $\$ 4,650,000$; the catch sold for $\$ 3,419,622$.

Among the more profitable voyages noted in the record are the following:

The ship Sarab, Captain Frederick Arthur, of Nantucket, sailed for the Pacific on May 26, I827, and reached home on April I9, I830, with 3497 barrels of sperm oil, the largest amount ever brought home by a Nantucket ship in a single voyage. It sold for $\$ 89,000$. In 1838 the New 
Bedford ship William Hamilton, Captain William Swain, brought home 4060 barrels of sperm oil, the record of all sperm voyages. She had sent home, meantime, I2I barrels, so that her total catch amounted to 4I8I barrels, then worth \$109,269.

The largest single cargo of whale oil ever brought to port was 5300 barrels in the South America, Captain R. N. Sowle, of Providence, Rhode Island. She also brought 200 barrels of sperm oil and 50,000 pounds of bone. She was away from home only 26 months. In $185 \mathrm{I}$ the George Washington, Captain Edwards, sailed from New Bedford, and in the course of her voyage took 7000 barrels of whale oil, 75 of sperm, and 50,420 pounds of bone. She sent home a large part of the catch by freighters.

While the Envoy made, as told, the record per cent profit on the original investment, the people of New London claim the honor of bringing in the cargo that sold for the highest price and gave the largest profit above the cost of the outfit. The Pioneer, Captain Ebenezer Morgan, sailed from that port on June 4, 1864, and returned on September 18, 1865, with 1391 barrels of oil and 
326 The Story of the New England Whalers

22,650 pounds of bone. Small as this take was, it sold for $\$ 151,060$. The cost of the outfit was $\$ 35,800$; but if from the gross income the wear and tear of the ship be deducted instead of the whole cost of the ship, the net receipts were above those of the Envoy. If the return per annum on this voyage be compared with that on the Envoy, the showing is still better.

The voyage of the little schooner Watchman, Captain Charles W. Hussey, of Nantucket, which sailed in September, I857, and returned in August of the next year, is worth mention. For while she saved only $4 \mathrm{I}$ barrels of sperm and 386 of whale oil, she brought in a quantity of ambergris that sold for $\$ 10,000$.

Ambergris is a secretion found in the bowels of the sperm whale. It is supposed to be the result of disease. It has been found afloat at sea and washed up on beaches, in various parts of the world, but usually it has been secured from whales not in good condition. "It is used in the preparation of fine perfumery, having the property of thoroughly uniting the ingredients." It sells for more than its weight in gold. In 1878 the 
Adeline Gibbs, of New Bedford, brought home I32 pounds that sold for more than $\$ 23,000$. In 1836 the bark Wade, Captain Charles B. Ray, of Dartmouth, Massachusetts, secured 50 barrels of ambergris, according to Starbuck. Between 1836 and I 880 the American whalers saved $1667 \frac{7}{8}$ pounds.

To show how a lucky voyage paid the owners and crew of a whaler, the record of the Charles Phelps, of Stonington, Connecticut, may be given. The Phelps sailed on August 29, I842, and returned March 30, 1844. The following figures are from a history of the ship written by James $\mathrm{H}$. Weeks, of Stonington, and printed in the Westerly, Rhode Island, Sun, in I900:

"In all thirty-four whales have been captured and thirty-three were taken by the various boats as follows:

"Larboard boat, I6; waist boat, 7; starboard boat, 7, bow boat, 3; found dead, 1 .

"Of this number five were sperm and the remainder (29) right whales. The boats were fast to six others, but the lines parted and they were lost. From twelve the irons drawed, and ten after being killed sunk and were not recovered. The number of irons lost during the voyage was thirty-four. Captain Palmer Hall made his report and manifest at the Stonington custom house 
328 The Story of the New England Whalers on April I, 1844, and it shows the cargo of the Charles $P$. Phelps to have been as follows:

" 2600 barrels of whale oil, I 40 barrels of sperm oil, and 2600 pounds of bone. The following value is placed on the entry of merchandise by Charles P. Williams, to whom it was consigned:

2600 barrels of whale oil at $\$$ II per barrel . $\$ 28,600$ I40 barrels of sperm oil at \$29 per barrel . $\quad 4,060$ 2600 pounds of whale bone at $33^{\frac{1}{2}}$ cents per pound

Total

One paper of unusual interest is the following under the head of "Amount paid officers and crew of ship Charles Phelps on her first voyage, April, 1844 :

Captain P. Hall . . . . . . . . . $\$ 2,544.59$

Gilbert Pendleton, Jr. . . . . . . 1,624.56

Thomas Burtch, Jr. . . . . . . . 942.29

John C. Nichols . . . . . . . 666r.36

Amos P. Wendleton . . . . . . 453.88

C. W. Austin . . . . . . . 44 43

S. Fletcher . . . . . . . . 4 449.31

A. Verhoff . . . . . . . 625.08

E. P. Berry . . . . . . . . 255.22

William Greenman . . . . . 297.64

William Cole . . . . . . 234.05

Silas Fitch . . . . . . . 453.88

Gurdon Hall . . . . . . 371.16" 
Not to fill the page with a list of forgotten names, it may be said that the smallest sum received by any one of the crew was $\$ 56.23$. He was a young boy, presumably. One sailor, Harry Baker, received $\$$ I25.12. The total amount paid to the crew was $\$ 13,289.77$. The owners took $\$ 28,120.33$, or more than twice as much as the entire crew who did the work. Charles W. Austin was a boat steerer, one of the men on whom the ship depended to fasten the small boats to the whales, yet his pay, $\$ 441 \cdot 33$, amounted to less than 76 cents a day for the voyage. It is to be noted that no man except the captain received in cash the sum set to his name. Every man had been obliged to buy clothing out of the "slop chest," a chest of goods carried by the captain for sale to the crew, and most of the men had had some money and an outfit advanced to them on entering the ship.

The pay of a skilled man like Austin seems extraordinarily small now, but the record shows that he shipped for the next voyage at a lay of only one seventy-fifth. The pay of the captain was only $\$ 4.36$ a day for the voyage, - less than 
$33^{\circ}$ The Story of the New England Whalers

mechanics are receiving now (1908) in New York City.

All that has been said about the "lay" system of pay being the fairest ever devised for seafaring men might be repeated here. The pay of the common sailors on the Phelps was as good on the average as that of seamen in any service at that time, and their work was usually much easier. Moreover, as already noted, the common sailor had a better chance for promotion.

Yet the fact remains that the owners of the ship - and of every ship of that day - took more than a fair share of the product of the labor of the crew.

This brings us to a consideration of what may be called the forecastle view of whaling in the days after the fishery had grown to a point where it was no longer possible to man the ships from among the young men of the ports and the vicinity of the ports, when the refuse of all ports had to be taken to fill up. The following statements, written by United States Consul F. M. Ringgold, from Paita, Philippine Islands, and published in Hunt's Merchants' Magazine, must certainly 
be without exaggeration because this magazine was the organ of all merchant-ship owners of that day (September, I849):

"All hands are huddled on board without a chance of looking at their chests, for the contents of which they have given a receipt which is to be deducted from their share or 'lay.' Each sailor is charged upon the owner's books with an average outfit of seventy dollars. By many owners interest is charged on this outfit from the day of sailing until the return of the vessel. When the sailor opens his chest he feels as we may suppose the man did who 'fell among thieves.' He finds that the contents of the chest are insufficient for his comfort, and that they are not worth twenty-five dollars in all. To compensate for this want of comfortable clothing, he may procure supplies from the owner's slop chest, which has been placed on board, by paying a handsome profit [100 to 200 per cent].

"The lay or share of a green hand is from a one hundred and eightieth to a two hundredth; that is, one barrel of oil out of every one hundred and eighty or two hundred that are taken. But from this, ten per cent is to be deducted for leakage, and frequently three per cent for insurance, although, if the vessel is lost, and is fully covered by insurance, the owners recover all and the men get nothing, because the charge is not made upon the men until the vessel gets home. The owner 
332 The Story of the New England Whalers

plays an open and shut game. If the vessel gets home the sailor pays the insurance, but if she is lost the owner pays the insurance and pockets the profits.

"The following is the result of one seaman's voyage for four years:

Sailor's share reduced to money . . . . . $\$ 262.25$ Less fitting, shipping, and medicine chests $\quad 10.00$ Ten per cent discount on $\$ 265.25$. . . . 26.22

Three per cent insurance on $\$ 262.25$ • . . 7.86 Money originally advanced . . . . . 70.00 Interest on same . . . . . . . . . . 16.80 Cash advanced during voyage . . . . . 30.00 Interest on same one per cent a month . . . 7.20 Clothing which he was compelled to draw owing to his bad outfit . . . . . . 40.00 To be deducted from sailor's share . . . $\$ 208.03$ Amount to be received at the end of the voyage $\overline{\$ 54.17}$

"From 3000 to 4000 young men yearly sail from the United States and, becoming disgusted, desert, and either from shame or moral corruption never return. The cause is small pay and bad treatment."

Francis Wayland, the eminent educator and author, in a lecture delivered before the New Bedford Port Society, on November 20, I842, a lecture which was preserved in pamphlet form, 
and is now before the writer, confirms almost every statement of the robbery of the sailors which was made by the consul quoted above. "Grossly imposed upon in the matter of outfit" and "the man at the close of his long service finds himself as poor as at the beginning" are some of the expressions used by Wayland in his discourse (p. I8).

Bluntly stated, the whale-ship owners, who were receiving from 25 to 50 per cent per year, clear profit, on their investment in the ships of that period, were willing to increase their gains by sheer robbery of the men whose work brought the gains. In what was called the Golden Era of whaling this robbery was the rule; the owners disposed to do the fair thing were apparently the exception. There is no reasonable doubt that some of the men to whom Wayland was talking, some of the members of the Port Society, were chief among those robbers, and their support of the Society was only an evidence of their hypocrisy.

Nor is that all. At this time, when the forecastle life was unendurable, the berth of the high- 
334 The Story of the New England Whalers

est officer on the ship became something scarcely worth seeking; for in the latter part of the Golden Era (1854), when ships were bringing in on an average $\$ 16,000$ a year each, the captains were paid on an average an eighteenth, or about $\$ 900$ a year. The matter is worth recalling because the custom of robbing seamen was common throughout the merchant service, and had its influence upon the loss of American prestige upon the high seas.

In every work upon the American whale fishery much stress is laid upon the effect of the Civil War in destroying the industry. It is noted that many ships were burned by Confederate cruisers fitted out in England, and that forty ships were purchased by the government and sunk in the channel at Charleston. As the government paid a large price (too large, in some cases) for each of the forty, and as the British government eventually paid something for the ships which the Confederates destroyed, it is not proved that the fishery was ruined to any extent by either the Confederate cruisers or the Stone Fleet. At worst, the owners as a class were as well able to 
begin the fishery anew at the end of the Civil War as they were at the end of the War of the Revolution.

It may be noted, too, in passing, that other American ship merchants were also in good financial condition at the end of the Civil War to renew their trade upon the sea, if they had wished to do so; that is, there was no lack of capital for sea purposes. Yet the whaling fleet which had numbered 508 vessels in 1860 numbered only 226 in 1865 , and the number in 1866 was only 199, although the prices of products were then higher than in 1865 .

Figures are prosy, but it should be interesting to recall that the prices of all whale products in the period of twenty years immediately following the Civil War were, on the average, higher than they were during the twenty years immediately before that war, and that the price of whalebone increased enormously during the later period. Thus sperm oil was selling at 73 cents in 1842 and at 82 in 1886 . It was $\$ 1.45 \frac{1}{2}$ in 1860 and $\$ 2.55$ in 1866 . Bone sold for 20 cents in $184 \mathrm{I}$, $80 \frac{1}{2}$ in $1860, \$ 1.71$ in 1865 , and $\$ 2.68$ in 1885 . 
336 The Story of the New England Whalers

The average yearly income per ship during the twenty years after the war was greater than that during the twenty years preceding the war. The total sales of products in the year I 846 amounted to $\$ 6,203,115.43$, or $\$ 8428$ for each ship in the fishery; the income per ship in $1885, \$ 15,550$. The average income per ship in 1854 was something over $\$ 16,000$, while the average in 1905 was about $\$$ \$ 9 , 000 .

With individual receipts higher on the average, the number of ships steadily decreased, but the seeming paradox is easily explained. The prices of oils have been maintained at the figures noted solely because the number of ships in the fishery was decreasing. The substitution of petroleum for whale oils as illuminants, and in part as lubricants, has destroyed the market for whale oils, or nearly so. The development of the cottonseed oil business also affected the fishery. If the price of whalebone had not increased during the years since the Civil War, it is likely that the whale fishery would have been abandoned long ago.

The competition of the new oils was not the sole 
cause of the decadence of whale fishery, however, as a glance at the other branches of the American merchant marine will show, for American ship merchants as a guild have been steadily losing their sea habit. They have turned from investments afloat to those on shore, save only as some have found profits in alongshore trades.

In connection with this change of habit, consider the effect of forecastle life upon the young Americans, as already described, and the effect of the disgust of the young men upon the ship-owning guild. For it is manifest that when the supply of young Americans failed in the forecastle, the supply of men for the cabin decreased, and with the failure of the supply of American officers there was a failure in the supply of new blood that should have been infused into the counting room. The young men who might have brought enterprise and enthusiasm, as well as knowledge, into the counting room to keep up the needed evolution, were riding the line on Texas cattle ranches or "booming" town sites in Kansas, or sinking prospect holes in the Rockies. The oldtime shipowners learned the business astride of 
338 The Story of the New England Whalers

the weather-topsail yard-arm. They looked the gale in the eye. Too many of the modern shipowners learned the business sitting astride of a tall stool, whence they looked a slow-moving clock in the eye. To such men the spinning business and speculating in stocks seem naturally more attractive than any kind of over-sea trade.

In the old days we had, and we had to have, sailors before we had ships. The glory of the Golden Era of the Yankee clipper, as of the Yankee whaler, was due to the superiority of the Yankee sailor, - the young men who waded barefooted through the snow in order to secure opportunity for a career that began in the forecastle and ended in the counting room. And the American flag will never regain its old-time place upon the Seven Seas until the ambitious, adventurous young American can find a more attractive career afloat than ashore.

Brief space will serve to tell about the modern uses of whale products. Sperm oil, as brought from the sea, is purified and then separated into two products, - oil and spermaceti. The spermaceti is used in making candles, in giving a gloss 
to linen in the laundry, and to some extent in medicine. Sperm oil is used as a lubricant and in softening leather in the tanneries. Crude whale oil when refined yields oil and a substance called whalefoots. Whale oil is used in ropewalks, and it is mixed with black lead and paraffin to make a lubricant. Some of it is usèd in making a soap that is used by gardeners in destroying insects; but most of the so-called whale-oil soap is made of inferior fish oils. The whalefoots is used by tanners. As all women know, the whalebone is used in corsets to give distinction to the human form. Steel stays are in common use, but no metal has yet been found that will take the place of the ever elastic whalebone. The best whips are made with a heart of whalebone. On the whole, the uses of whale products are few in number, but each has thus far held a place which nothing else could fill. 


\section{XIII}

\section{THE MUTINEERS AND SLAVERS}

FTER the time came when whaler captains went to the "crimps" for crews, mutinies often occurred in the fishery.

That is to say, many crews became so discontented for various reasons that they broke out in open rebellion, refusing to do duty, deserting the ship, etc.

The causes of these mutinies are not far to seek. Testimony that must be believed shows that the officers were often brutal in their treatment of the men, and were willing to increase the profits of the ship by robbing and, sometimes, starving them. Starving crews was certainly uncommon in the whale fishery; but legalized robbery was, as said, common even in Wayland's day.

The ordinary mutiny was nothing more than what is now called a strike. The men fled ashore 
when opportunity offered, and on other occasions made protests to the captain in a body. Usually a strike was ended by a free use of fists, belayingpins, or such other weapons as the officers could get hold of. The officers stood together; the men rarely did so.

Of these lesser mutinies nothing more need be said here; but two uprisings, in which the forecastle men triumphed through a slaughter of some of the officers, are memorable.

The ship funior, Captain Archibald Mellen, Jr., sailed from New Bedford on July 2I, I857, bound for the Pacific by way of the Indian Ocean. On the following Christmas day the ship was in south latitude $37^{\circ} 5^{\prime}$ and east longitude $166^{\circ}$ $57^{\prime}$. The log of the ship, as printed in the New Bedford Mercury, says of the day:

"At sundown shortened sail to maintopsail and foresail. Middle part, strong gale. Latter part, heavy gale from southward. Lying to at sundown."

After shortening sail, Captain Mellen gave each man a small glass of grog because it was Christmas, and then in the usual course the deck 
342 The Story of the New England Whalers

was left in charge of the boat steerers while captains and mates turned in for the night.

At one o'clock the next morning, while the gale was raging with undiminished violence, five of the crew, Cyrus Plummer (the leader), John Hall, Richard Cartha, Cornelius Burns, and William Herbert, all armed with loaded guns, entered the cabin, leaving five others on deck to guard the entrance to the forecastle and keep the other members of the crew, all of whom were in ignorance of the plot, from coming on deck. The captain and all three of the mates were sleeping soundly. Pointing their guns at these officers, and taking the word from Plummer, all fired together. Apparently the guns wabbled, for not one of the officers was killed outright. The captain, rising up, said:

"Oh, my God! What is this?"

Plummer at once seized him by the hair, and saying, "G__ d - you, it is me!" struck him several blows with a hatchet and killed him.

As the third mate strove to rise, Cornelius Burns stabbed him with a boarding knife, the swordlike weapon used in cutting up blubber, and 
killed him. Meantime Cartha struck at the second mate with a similar weapon, but missed him, and then fired a pistol at him. Before he could finish the work of killing this officer, however, all the mutineers were called on deck to overawe the forecastle men who had been aroused by the shooting, and the first and second mates were left in the cabin, wounded, but still able to walk. The first mate, Nelson Provost, then escaped to the hold while the second mate went on deck, where he found Plummer in full control.

Under Plummer's orders the men now threw the dead officers overboard and then the second mate was put in irons. Some of the mutineers wanted to kill him, but Plummer would not allow it. The ship was then headed toward the Australian coast, where the mutineers intended to land, and the first mate was left in the hold to shift for himself. On drawing near to land, however, the need of a navigator, who, like the mate, was acquainted with the coast, led the mutineers to hunt him out. The mate himself said afterwards that when they brought him up on deck his hair literally stood on end through fear 
344 The Story of the New England Whalers

that he was to be killed. Of course he readily agreed to serve as pilot.

A landfall was made at Cape Howe. Heaving the ship to, the mutineers loaded two whale boats with such plunder as the ship afforded and pulled ashore. Before leaving, however, Plummer, who knew that the ship would be taken to some civilized port as soon as possible, wrote the story of the mutiny in the log book in order to clear those left on board from all suspicion of having had any part in the revolt. As that was an unheard-of proceeding, the document is worth giving in full. William Herbert wrote at Plummer's dictation as follows:

"This is to certify that we, Cyrus Plummer, John Hall, Richard Cartha, Cornelius Burns, and William Herbert, did, on the night of December 25th last, take the ship funior and that all others in the ship are quite innocent of the deed.

"The captain and third mate were killed, and the second mate was wounded and taken prisoner at the time. The mate was wounded in the shoulder with the balls from a whaling gun. At 
the time we fired we set his bed on fire, and he was obliged, for fear of suffocation, to take himself to the lower hold, where he remained until Wednesday afternoon.

"We could not find him before that, but we undertook a strict search and found him then. We promised his life and the ship if he would come out and surrender without any trouble, and so he came out. Since he has been in the ship he has been a good officer and has kept his place. We agreed to leave him the greater part of the crew and we have put him under oath not to attempt to follow us, but to go straight away and not molest us. We shall watch around here for some time and if he attempts to follow us or stay around here, we shall come aboard and sink the ship.

"If we had not found Mr. Nelson the ship would have been lost. We are taking two boats and ten men and everything we want. We did not put Mr. Nelson in irons on account of his being wounded, but we kept a strict guard on him all the time.

"We particularly wish to say that all others 
346 The Story of the New England Whalers

in the ship but we five aforementioned men are quite innocent of any part in the affair.

$$
\begin{array}{ll}
\text { “(Signed) Cyrus Plummer. } \\
\text { John Hall. }
\end{array}
$$

“Witnesses:

Richard Cartha.

"Hugh Duff.

Cornelius Burns.

Henry T. LORd.

William Herbert.

Herman Graf."

The ship made port at Sydney. The authorities captured eight of the mutineers, including Plummer. They were placed on the funior, where each was confined in a heavy hard-wood cage lined with iron, and a guard of six well-armed men was stationed over each cage. A new crew was shipped and then she sailed for home.

As the story was told by the officers, the mutiny was unprovoked, and Starbuck speaks of it as a "diabolical atrocity." When Plummer and his associates were put on trial, however, Benjamin F. Butler, the noted Civil War general, took up the defence with such effect that Plummer only was found guilty of deliberate murder. The facts of the mutiny were not disputed, but it was testified that the men had been driven to desperation 
by hard fare and ill treatment on the part of the captain. The judge charged the jury that all of the eight men were equally guilty of the death of the two officers, but the jury, believing the story of the ill treatment of the men, cleared four of the accused, found three guilty of manslaughter, and Plummer, as said, guilty of deliberate murder. Plummer was sentenced to die, but when the facts in his case were placed before President Buchanan, the sentence was commuted to imprisonment for life. Plummer died in prison. The three convicted of manslaughter were in time released.

There is but one mutiny known to the annals of the whalers in which there was no provocation, and that was the one on the Globe, Captain Thomas Worth, of Nantucket. The Globe sailed from Edgartown, Martha's Vineyard, for the Pacific on December 15, 1822. She had been a lucky ship; she was the first that ever brought in a cargo of 2000 barrels of sperm oil. Rounding the Horn in March, she reached Oahu in May, 1823, and there the first symptom of trouble appeared in the desertion of six men. The reader will remember the old missionary hymn that described the Pacific islands as regions 
348 The Story of the New England Whalers

"Where every prospect pleases

And only man is vile."

On hearing those words sung at the bethel chapels of civilized ports, many sailors of sinful habits - especially such as found slave ships attractive - made haste to ship on whalers in order that they might thus reach those wondrously beautiful and wicked islands. The six men who deserted from the Globe were of this character.

Having had none too many men before these deserted, Captain Worth picked up on the island six to take their place, of whom four were white men, one was a negro, and one a native of the islands, as follows: Silas Payne (formerly of Sag Harbor, Long Island), John Oliver, Anthony Hanson, Thomas Liliston, and William Humphries (negro, from Philadelphia), besides the native. These men were known to be of the class called beachcombers. They were lazy vagabonds who had deserted from other ships to live the life of the savage natives, and had become weary of it so far that they were willing to ship for a time in order to secure some of the products of civilization not readily to be obtained in the islands. 
From the day the Globe left Oahu to go cruising, the new recruits were lazy and insolent. To make them work well was impossible. In spite of, or perhaps because of, the character of these men, a boat steerer, named Samuel B. Comstock, became very friendly with them, and especially with Payne. Comstock, after the usual fashion, lived in the cabin, where he had been well treated; the third mate, Nathaniel Fisher, had been too kind to him. For Comstock had challenged Fisher to a wrestling match at a time when men from another ship were visiting on board, and after Fisher had proved himself the better wrestler, Comstock struck him. For this Fisher threw him to the deck and held him until the appearance of anger passed away, and then let the matter drop.

In time the tales told by the beach-combers about their life among the savages led Comstock and some of the other members of the original crew into a conspiracy to kill the officers, and then sail to the Malgraves and there abandon themselves to such joys as they might find.

Accordingly, on the night of January 2.5, I824, 
$35^{\circ}$ The Story of the New England Whalers

while Comstock was in charge of the deck, the conspirators armed themselves for the attack. With Comstock in the lead, and the negro Humphries carrying a lamp to light the way, they found Captain Worth asleep in a hammock. Comstock hit him on the head with an axe, killing him instantly. Payne then made a thrust with a boarding knife at William Beetle, the mate, but the blow failed, and the mate, leaping up, seized Comstock by the throat. This attack made Comstock drop his axe, but Payne placed a boarding knife in his hand and with that he knocked the mate, seriously wounded, into the pantry. Comstock then stabbed him with the knife, disabling but not killing him.

Turning from the mate, Comstock now locked the door to the room occupied by Second Mate John Lumbard and Third Mate Nathaniel Fisher. His movements had been so quiet, thus far, and withal so swift, that neither of these officers had been aroused. Having secured them in their room, Comstock now loaded two muskets, each of which had a bayonet affixed to it. Pointing one of the muskets toward the door in such a way 
as he supposed would enable him to hit one of the officers, he fired.

"Was either of you hit ?" said he.

"Yes, I am shot in the mouth," replied Fisher.

At that Comstock opened the door and thrust a bayonet at Lumbard, but slipping in the blood on the cabin floor, he fell headlong. Fisher at once picked up the musket and he was pointing it at Comstock's breast, when the mutineer promised to spare the lives of the remaining officers. Fisher foolishly accepted the promise and gave up the musket. But no sooner did Comstock get the weapon into his hands, than he thrust the bayonet repeatedly into Lumbard and then, turning upon Fisher, he reminded him of the wrestling match, and said:

"You have got to die!"

"If there is no hope, I will at least die like a man," said Fisher, and then added, "I am ready." Comstock shot him through the head, killing him instantly. A little later the mate and Mr. Lumbard, though both were yet alive and conscious, were thrown into the sea. Lumbard clung to the rail as well as he could, when they shoved him 
$35^{2}$ The Story of the New England Whalers overboard, and for a time he swam beside the ship, begging to be taken on board.

Having obtained full possession of the ship, the mutineers headed her for the Malgraves. On the 28 th the negro, Humphries, was seen loading a pistol, and when asked why he was doing so, he said he had heard two of the sailors plotting to retake the ship. The two denied the charge, of course, and Comstock ordered that they and the negro be tried by a jury. The negro, when arraigned, answered a few questions in a low and hesitating voice, and then without further proceedings, Comstock, who had presided as judge, said :

"It appears that William Humphries has been accused of a treacherous and base act, in loading a pistol for the purpose of shooting Mr. Payne and myself. Having been tried, the jury will now give in their verdict, whether guilty or not guilty. If guilty he shall be hanged to a studdingsail boom rigged out eight feet upon the foreyard, but if found not guilty Smith and Kidder shall be hung upon the aforementioned gallows."

Smith and Kidder were the men Humphries 
had accused. The negro was at once pronounced guilty. He was then seated on the rail beneath the foreyard, and a noose was placed around his neck. At this moment he said, "Little did I think I was born to come to this - " and then, before he could say more, he was hoisted to the end of the studding-sail boom, the entire crew hauling on the line.

On February 14, the Globe anchored at the Malgraves. To govern his crew Comstock had issued, meantime, a decree which he called the law, as follows:

"If any one sees a ship and does not report it immediately, he shall be put to death. If any one refuses to fight a ship, he shall be put to death; and the manner of their death is this: They shall be bound hand and foot and boiled in the try-pots of boiling oil."

All hands signed these "laws." Comstock went ashore to live as soon as possible. A considerable quantity of provisions and plunder (including a Bible, curiously enough) was taken ashore. Tents were made from sails. In a few days Payne and Comstock quarrelled. Oliver 
354 The Story of the New England Whalers and the other beach-combers sided with Payne, and with loaded musket hid near Comstock's tent in order to shoot him as soon as he should appear. When Comstock came into view he saw the gang, and drawing a sword, he started toward them with menacing motions. When they aimed their muskets at him, however, he shouted:

"Don't shoot me! Don't shoot me! I won't hurt you."

In spite of this pleading four muskets were fired, and he fell, pierced through the breast and the head with bullets. He was dead before his body reached the ground; but Payne, through fear that the shooting had not killed him, chopped his head almost off with an axe.

Having sewed the body in canvas, Payne ordered a grave dug exactly five feet deep. In this the body was buried. A chapter of the Bible was read and muskets were discharged by way of a funeral service.

Comstock was killed on February 17. That night the ship was left in charge of Gilbert Smith, a boat steerer, and five other men. As soon as night came these men cut the cable and sailed 
away to Valparaiso, where they delivered the ship to Michael Hogan, the American consul.

The flight of the ship left Silas Payne, John Oliver, Thomas Liliston, Roland Coffin, William Lay, Cyrus M. Hussey, Columbus Worth, and the Sandwich Islander on the beach. For several days Payne and his chums ruled the camp by terror. They tried to rule the natives in the same way, and to this end they brutally flogged two women and put one man in irons. For this, on February 23, the natives began throwing stones at the camp. Payne, seeing what he had brought upon himself and associates, strove to pacify the natives, but it was now too late. They continued the attack, and all but Lay and Hussey were soon killed. Why these two men were saved was never definitely learned. Each was adopted by a native family, and they were well treated until the United States war schooner Dolphin, Lieutenant Commander John Percival, reached the island on December 29, 1825, and took them away.

The story of the whale ships that were used in carrying slaves from Africa to a market in the two 
356 The Story of the New England Whalers

Americas has never been written. In Starbuck's list of the sailings of whalers from different American ports it is said that the bark Margaret Scott, Captain Oliver S. Cleaveland, belonging to Rodney French, of New Bedford,' and the Fame, Captain Mitchell, belonging to William Tate, of New London, were diverted to the slave-trade, the former on a voyage begun September 16, 1857, and the other during a voyage begun on June 18,1844 . Of the circumstances, nothing is told. The New Bedford Mercury, in speaking of the Stone Fleet that was fitted out to block the port of Charleston, South Carolina, during the Civil War, says:

"Among the craft purchased was the Margaret Scott, a vessel which had been seized a short time previously by a United States marshal on the grounds that she had been fitting for a voyage in slave-trading. Her commander and owners were found guilty of the charge, and the Scott was sold at auction, and acquired for the Stone Fleet."

The whaler Herald, Captain Samuel Barker, that belonged to Charles P. Williams, of Stonington, Connecticut, is mentioned by Starbuck as follows: 
"Sold at Rio Janeiro (?), I848, by captain. Also 600 sperm."

The story of the Herald, as told in a message from President Polk, with accompanying documents (dated March 2, I849), shows that the captain, after selling the oil, made a slave voyage and then disappeared with the ship.

The Laurens, Captain Eldredge, belonging to Tiffany \& Halsey, of Sag Harbor, was seized in the harbor of Rio Janeiro in $\mathrm{I} 84 \mathrm{I}$ by Commodore Storer, U.S.N., on a charge of fitting out for the slave-trade. The document just quoted also declares that another whaler had been fitted out at Bahia, and that it was supposed to be the Cynosure, Captain Simonds, belonging to J. F. Trumbull, of Stonington, Connecticut. Of this whale ship Starbuck says that she was "sold in Bahia." It is reasonable to suppose that slave-traders bought her with the understanding that she was to be sailed under the American flag, and by the American captain and crew, to the slave coast. This done the captain was to deliver her to the new owners as soon as he learned that the slaves were on the beach ready to embark. 
$35^{8}$ The Story of the New England Whalers

The flag thus protected the ship to the last moment.

Of the noted whaler bark Augusta, that was fitted out for the slave-trade by Appleton Oakes Smith, a son of the poetess Elizabeth Oakes Smith, it is recorded that she was sold to Smith before she was fitted out. It is worth noting perhaps that the price received by the owners was $\$ 7000$, a fact that has some bearing on the cost of fitting out ships for the whale fishery.

When certain peculiarities of the whale-ship are considered in connection with the needs of a ship in the slave-trade, it is seen that all whalers were very well adapted to carry "black ivory," as the negroes were called. Thus the try-pots were excellent for cooking large quantities of food, and the barrels used normally for oil would serve equally well for carrying water needed in such large quantities on a slaver. What was of more importance still, a whale-ship could sail to the coast of Africa with her try-pots in place and with barrels full of water, and when within sight of the beach could defy the inspecting officer from any of the men-o'-war stationed on the coast 
to suppress the slave-trade. For whales were to be found on that coast; moreover it was the custom to keep water in such barrels as were set up so that they would not shrink apart. The temptation to enter the trade was enormous. Thus while a whale-ship averaged, as noted, $\$ 16,000$ a year income, in 1854 the average profit on a cargo of slaves delivered in Cuba or Brazil was about $\$ 250$ a head. If well handled, a whaler might deliver from 600 to 800 slaves, and so clear from $\$ 150,000$ to $\$ 200,000$ on a single trip. While a captain averaged $\$ 900$ a year in the whale fishery, he might receive $\$ 9000$ or more for a single voyage on a slaver; what he might make by running away with a ship shall appear.

In the meantime the public, especially the New York ship-owning public, looked upon the laws against the slave-trade as the Wall Street financiers of 1906 regarded the laws forbidding railroads giving rebates to favored shippers. Lawyers were found to declare the anti-slave-trade laws unconstitutional, just as lawyers in 1906 declared laws pertaining to railroads unconstitutional.

The slaver captains and mates used to live in 
360 The Story of the New England Whalers

the East Side region of New York, between James and Houston streets. The arrangements for slaver voyages were made at the Astor House and other first-class hotels. If by chance a slaveship was captured, ship merchants of the highest reputation stood ready to bail the accused. If by any chance a slaver officer were incarcerated for a time, he lived the life of a Sybarite while behind the bars. Even after the war was begun, the consideration shown these men whom the law declared to be pirates was such as to astound the modern reader. Thus it is a matter of record that one of the United States attorneys detailed to prosecute Appleton Oakes Smith was seen dining at the most stylish restaurant in town with the criminal he was to try. It was this shocking condition of public opinion in the United States that led Henry A. Wise, of Virginia, when in Rio Janeiro, to write (February I8, I845) to the Hon. John C. Calhoun, Secretary of State, saying:

"I beseech, I implore the President of the United States to take a decided stand on this subject. You have no conception of the bold effrontery and the flagrant outrages of the African 
slave-trade. . . . And every patriot in our land would blush for our country did he know and see, as I do, how our own citizens sail and sell our flag to the uses and abuses of that accursed traffic, in almost open violation of our laws. We are a byword among the nations, - the only people who can fetch and carry any and every thing for the slave-trade, without fear of English cruisers; and because we are the only people who can, are we to allow our proudest privilege to be perverted, and to pervert our own glorious flag into the pirate's flag?"

For more than fifteen years after that letter was written the state of public opinion allowed the free use of the flag to the slaver pirates. With this fact in mind, one is able to appreciate the assertion that, in all the annals of the whale fishery, no statement more to the credit of the American whalemen can be found than this: that of more than 2000 ships which sailed in the fishery between 1808, when the slave-trade became unlawful, and the Civil War, when blood and fire purified the public mind in that one respect, only five whale-ships became known to 
362 The Story of the New England Whalers

the records as slave carriers. A few others were, very likely, so used, but the record does not show the fact.

The story of the slaver-whaler Fame is soon told. Captain William Tate bought her in Boston in 1844 , and sent her to sea on June 18 . On the way to the Pacific the mate was killed by a whale, and in 1846 Captain Mitchell died. There is nothing to show whether she had taken any oil, meantime. The second mate, a native of the Azores whose home was in New London, and who had shipped under the name of Anthony Marks, took the ship to Rio Janeiro, where she arrived in December, 1846. Marks told the United States consul, Mr. Gorham Parks, that the ship needed repairs, and that when he had made them, he intended to go whaling and try to make amends for the ill luck of the ship thus far. The consul, of course, approved this proposition and supervised the repairs; but when they were completed, Marks took on supplies of which Parks knew nothing, and then, with a number of Brazilians and Portuguese on board as passengers, he sailed away. Having gone to the east coast of 
Africa, a cargo of 530 slaves was taken on board. These were so well handled that only three died on the way back, and the survivors were landed at Amazonas, near Cape Frio, Brazil.

For his success, Marks received $\$ 40,000$. The forecastle men received from $\$ 250$ to $\$ 340$ each. The slaver voyage lasted about five months.

The consul made an effort to capture the stolen ship, but he failed. Marks took her to Paranagua, where he altered her so that she could not be recognized by her owners. Of her subsequent career there is no record, but she was undoubtedly sailed in the trade until unspeakably foul and then burned.

As a final touch to the picture of the whalers as slavers, brief reference may be made to the loss of the ship Cassander, Captain Winslow, that sailed from Providence on November 19, I847. It appears that, when on the coast of Africa, she took on board, as members of the crew, two negroes. From the coast the ship sailed out to sea, and between 4 and 5 o'clock in the morning, on May I, I848, the crew found her on fire. When the alarm was given, and all hands were 
364 The Story of the New England Whalers

called to save the ship, the two Africans jumped into the sea. Lines were thrown to them, but neither would accept the offer of help, and one of them soon sank. The other was picked up by a boat and brought on board, where he confessed that he and the other negro had set fire to the ship, because they believed they were to be carried to America and sold as slaves. The efforts to extinguish the flames proved vain. The crew were driven to the boats, in which they drifted without food for ten days before they were picked up. In the meantime two of them had died from starvation. 


\section{XIV}

\section{TALES OF WHALERS IN THE CIVIL WAR}

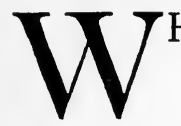

HEN one asks the people of New Bedford for the name of the best-remembered whaler hero of the Civil War, they reply promptly that it was Commander William P. Randall. Randall, as the story is told, first gained fame locally as the second mate of a Pacific whaler.

The third and fourth mates of the ship were relatives of the captain, and, as sometimes happened in the whale fishery, the skill and success of the second officer did not prove wholly acceptable to the captain, for the reason that the other mates were thereby thrown somewhat into the shade. While laboring under such a disadvantage as these circumstances imposed, Randall, and the other mates as well, lowered for a whale. The captain ordered Randall to play loose boat, - lie off, - allow the others to strike the whale, 
366 The Story of the New England Whalers and then go in and help as he could. The orders were obeyed, of course. In due time the whale was struck by the third and fourth mates, and then when Randall pulled in and fastened to it the whale at once turned to fight. In the mêlée the whale turned a somersault between the boats and came up with Randall's line tangled in its teeth. The other boats now cut loose, and the whale fled with Randall in tow.

Just as night came the men managed to get the boat within reach, and Randall killed the whale; but when he was boring a hole through the whale's fluke for the tow line, he had the misfortune to "split his hand quite open to the bone on the spade edge." And then, "as if his troubles must needs come upon him all at once," says Bullen, in an account written for the New Bedford Mercury, "he had hardly completed his rude surgery on the wounded hand when a huge Kanaka, his harpooner, suddenly seemed to become crazy with fear of the darkness and his inability to see the ship. He howled with fright and demanded water and food.... Randall tried to soothe the frantic man, but finding that he could not do 


\section{Tales of Whalers in the Civil War ${ }^{36} T$}

so, and that the rest of the crew showed signs of demoralization, he reached for his bomb gun, and calling all hands to witness that if compelled to shoot the Kanaka, he was doing such an act only in the common interest, he sat pointing the gun with its awful charge at the mouthing, gesticulating negro, trying meanwhile to ignore the pain which was slowly deadening his left side from the jaw to the waist.

"And there in his loneliness and full acceptance of responsibility sits the youth, Randall, feeling face to face with death, . . . but fully determined to die if he must man fashion, ... until with eyes that grow humid with gratitude he sees the tender flush of dawn mantling the east, . . . and lifting his voice in the long mellow 'Sail ho!' brings all his men out of their slumbers into rejoicing consciousness."

With such a reputation as the spirit thus exhibited could give him, Randall entered the Union navy at the outbreak of the Civil War, secured the rank of acting master, and was assigned to the old sailing sloop-of-war Cumberland. $\mathrm{He}$ was stationed in command of the after pivot gun. 
368 The Story of the New England Whalers

On March 8, 1862, the Cumberland was lying at anchor just to the west of Newport News Point, at Hampton Roads. The frigate Congress was lying not far away, and at intervals up the roads toward Fortress Monroe were a number of other Union war-ships. Up the James River, and just within the range of vision of the lookout of the Cumberland, were a number of small Confederate steamers that had recently come down the river and were lying at anchor as if meditating a run through the blockade which the Cumberland and the other ships were maintaining. Lieutenant George U. Morris, the executive officer, was temporarily in command of the Cumberland, the commander having been ordered elsewhere for the day.

It was a very quiet, pleasant day. The crew of the Cumberland took in hand the laundry work of the ship that morning, and when noon came the clothes were on lines strung up in the rigging.

For weeks past rumors about a Confederate ironclad that was said to be building at Norfolk had come to the fleet. "Contrabands," as the runaway slaves were called, brought the rumors. 
Tales of Whalers in the Civil War 369

They had reported the new ship (known as the Merrimac) nearly ready for action, but the commanding officer of the Union ships was one of the conservatives who did not have any faith in the negroes, and, what was of more importance, he had no idea that the "new-fangled" notion of a ship would amount to anything even if she did come.

A little before I o'clock, when she was by no means expected, the Confederate ship came into view. She was out for a trial trip, and her commander, Commodore Franklin Buchanan, was determined to give her such a trial as no ship had ever had before. Steaming across the bay he headed first of all for the Cumberland. The drums beat to quarters, and the crew were standing at their guns as the strange-looking craft drew near. They saw her pass the frigate Congress, firing her bow gun at that ship as she came, and then they opened on her with such guns as would bear. Chief among these was the after pivot gun, under the command of Master Randall. With cool precision he loaded and fired, - as coolly as he had in former times loaded and fired the bomb 
370 The Story of the New England Whalers

gun at whales. But the shot, though aimed with deadly accuracy, made no more impression than if he had fired a musket instead of a cannon. Wholly uninjured, the great ironclad came on until, with a mighty crash, her bow was driven into the side of the Cumberland. Then she drew away, and with her crew working her guns she passed on, steamed up the James a little way, turned around, and came back beside the old sloop-of-war.

The Cumberland was settling by the bow rapidly, and the whole crew could hear the water roaring in through the hole that had been made in her. But when the Confederate ranged up and demanded that she surrender, Lieutenant Morris replied:

"Never! I'll sink alongside."

Then "the gun crews kicked off their shoes and stripped to the waist. Tanks of cartridges were hoisted on the gun deck and opened, and round after round was fired at the ironclad. Never did a crew fight a ship with more spirit and hardihood than these brave fellows of the Cumberland while the vessel was going down." 


\section{Tales of Whalers in the Civil War $37 \mathrm{I}$}

Finally the rising tide reached the deck where Randall and his men were working their pivot gun. The order to abandon ship had already been given, and those able to do so had fled over the rail;-all but Randall's crew. The water was lapping their feet, but they lingered until Randall aimed and fired the gun, and then with the water sissing into the gun's hot muzzle they leaped for life.

On the recommendation of Lieutenant Morris, who is memorable forever as one who would "sink alongside" rather than surrender, Master Randall was promoted to the rank of volunteer lieutenant "for coolness and bravery." $\mathrm{He}$ eventually obtained the commission as ensign in the regular line of the navy, and was placed on the retired list as a lieutenant commander on August 6, I886.

Although more than forty years have now passed since the end of the Civil War, the old ship merchants of New England, and especially the whale-ship owners, yet find some difficulty in calling the Confederate cruisers by any other name than "pirates." The thorough work done 
372 The Story of the New England Whalers

by some of those cruisers was enough, naturally, to create bitter memories; but to add to the bitterness the cruiser captains did some things that outraged the feelings of the captured ships' crews in a way hard to forget. Thus when Commander Raphael Semmes, while in command of the cruiser Sumter, learned that the crew of the Confederate privateer Savannab had been placed on trial in New York for piracy, he confined eight of the merchant seamen he had captured and gave them "to understand that they were hostages, and that their discharge, their close confinement, or their execution, as the case might be, depended upon the action of their own government in the case of the Savannab prisoners." (Memoirs of Service Afloat, p. I78.)

As was eventually seen, the men of the $S a$ vannab were not pirates; they had been legitimately serving the Confederate government. The Confederate president, Jefferson Davis, on learning that the Savannab's men were to be tried as pirates, ordered a number of United States soldiers placed in confinement as hostages to abide the fate of those sailors, and in this act he was, 
Tales of Whalers in the Civil War 373 of course, entirely justified. It was one thing, however, for the president of the Confederacy to select captured soldiers as hostages in such a case, and an entirely different one for the commander of a cruiser to select merchant seamen for a similar purpose.

Then, after the Federal authorities had captured and imprisoned in irons the paymaster of the Sumter, Semmes, instead of referring the matter to his government for action, avenged himself and the paymaster, as he said, by putting in irons and otherwise ill treating the crews of several captured whalers. "I pursued this practice, painful as it was, for the next seven or eight captures, putting the masters and mates of the ships, as well as the crews, in irons." (Memoirs of Service Afloat, p. 429.)

Starbuck, in describing another feature of the work of the Confederate cruisers, says:

"They adopted a device to ensnare their victims which can but be severely reprobated as inhuman. Capturing a vessel, they waited until night had fallen upon the scene, and then, firing her, they pounced upon the unfortunates who, 
374 The Story of the New England Whalers

obeying the natural impulses of humanity, bore down for the burning craft to save the lives they believed to be endangered. Thus were captured and burned by the Alabama the ships Benjamin Tucker, Osceola, Virginia, and Elisha Dunbar, of New Bedford; Ocean, of Sandwich; Alert, of New London, and schooners Altamaba, of Sippican, and Weather Gage, of Provincetown, all of whom, attracted by the burning of the Ocean Rover, of Mattapoisett, hastened to rescue the shipmates whose lives they believed to be imperilled."

Semmes' story of the burning of the Ocean Rover is entirely different from that told by Starbuck, and it may be given here not only as a matter of justice to Semmes, but because it describes in an interesting way the destruction of a number of the whaling fleet. Semmes says, in Memoirs of Service Afloat, p. 43I :

"Later in the afternoon we chased a large ship, looming up almost like a frigate, in the northwest, with which we came up about sunset. We had showed her the American colors, and she approached us without the least suspicion that 


\section{Tales of Whalers in the Civil War 375}

she was running into the arms of an enemy. . . . This large ship proved to be the Ocean Rover, of New Bedford, Massachusetts. She had been out three years and four months, cruising in various parts of the world; had sent home one or two cargoes of oil, and was now returning herself with another cargo of eleven hundred barrels. The master, though anxious to see his wife, and dandle on his knee the babies that were no longer babies, with true Yankee thrift thought he would just take the Azores in his way home, and make another 'strike' or two, to fill up his empty casks. The consequence was, as the reader has seen, a little disappointment. I really felt for the honest fellow, but when I came to reflect for a moment upon the diabolical acts of his countrymen of New England, who were out-heroding Herod in carrying. on against us a vindictive war, filled with hate and vengeance, the milk of human kindness which had begun to well up in my heart disappeared, and I had no longer any spare sympathies to dispose of.

"It being night when the capture was made, I directed the prize to be hove to in charge of a 
376 The Story of the New England Whalers prize crew until morning. In the meantime, however, the master, who had heard from some of my men that I had permitted the master of the Ocmulgee and his crew to land in their own boats, came to me and requested permission to land in the same manner. We were four or five miles from the land, and I suggested to him that it was some distance to pull.

" 'Oh, that is nothing,' said he; 'we whalers sometimes chase a whale on the broad sea until our ships are hull down and think nothing of it. It will relieve you of us the sooner, and be of some service to us besides.'

"Seeing that the sea was smooth, and that there was really no risk to be run, for a Yankee whale boat might be made, with a little management, to ride out an ordinary gale of wind, I consented, and the delighted master returned to his ship to make the necessary preparations. I gave him the usual permission to take what provisions he needed, the whaling gear belonging to his boats, and the personal effects of himself and men. He worked like a beaver, for not more than a couple of hours had elapsed before he 
was again alongside of the Alabama with all his six boats with six men in each, ready to start for the shore. I could not but be amused when I looked over the side into these boats at the amount of plunder that rapacious fellow had packed into them. They were literally loaded down with all sorts of traps, from the seaman's chest and bedding to the tabby cat and parrot. Nor had the 'main chance' been overlooked, for all the 'cabin stores' had been secured, and sundry barrels of beef and pork besides. I said to him:

"Captain, your boats appear to me to be rather deeply laden; are you not afraid to trust them?"

"'Oh, no,' he replied; 'they are as buoyant as ducks, and we shall not ship a drop of water.'

"After a detention of a few minutes, during which my clerk was putting the crew under parole, I gave the master leave to depart.

"The boats, shoving off from the side, one by one, and falling into line, struck out for the shore. That night landing of this whaler's crew was a beautiful spectacle. The moon was shining brightly, though there were some passing 
378 The Story of the New England Whalers

clouds sailing lazily in the upper air. Flores, which was sending off to us, even at this distance, her perfumes of shrub and flower, lay sleeping in the moonlight. The rocky islets that rise like so many shafts out of the sea, devoid of all vegetation and at different distances from the shore, looked weird and unearthly. The boats, moving swiftly and mysteriously toward the shore, might have been mistaken, when they had gotten a little distance from us, for Venetian gondolas with their peaked bows and sterns, especially when we heard coming over the sea, a song, sung by a powerful and musical voice, and chorussed by all the boats. Those merry fellows were thus making light of misfortune, and proving that the sailor, after all, is the true philosopher. But little I dreamed, as I stood on the deck of the Alabama, and witnessed the scene I have described, that four years afterward it would be quoted against me as a violation of the laws of war! And yet so it was. It was alleged by the malice of my defamers, who never have and never can forgive me for the destruction of their property, that miles away at sea, in rough and 


\section{Tales of Whalers in the Civil War 379}

inclement weather, I compelled my prisoners to depart for the shore in leaky and unsound boats, at a hazard of their lives, designing and desiring to drown them! And this is all the thanks I received for setting some of these fellows up as nabobs among the islanders. Why, the master of the Ocean Rover, with his six boats and their cargoes, was richer than the governor when he landed in Flores, where the simple islanders are content with a few head of cattle, a cast net, and a canoe.

"The Alabama had now two prizes in company [the schooner Starlight, a cargo carrier bound from Boston to the Azores, had been taken before the Ocean Rover appeared], with which she lay off and on the island during the night, and she was destined to secure another before morning. I had turned in and was sleeping soundly when about midnight an officer came below to inform me that there was another large ship close on board of us. I was dressed and on deck in a few minutes. The stranger was plainly visible, being not more than a mile distant. She was heading for the island. I wore ship as 
380 The Story of the New England Whalers

quietly as possible and followed her, but she had in the meantime drawn some distance ahead, and an exciting chase now ensued. We were both close-hauled on the starboard tack, and the stranger, seeing that he was pursued, put every rag of sail on his ship that he could spread. I could but admire her with her square yards and white canvas, every sheet home and every leach taut. After a chase of about four hours, day broke, when we hoisted the English ensign. This was a polite invitation to the chase to show her colors, but she declined to do so. We now felt sure that she was an enemy, ... and fired a blank cartridge. Still she was obstinate. She was steering for Flores and probably, like the Starligbt, had her eye on the marine league. Having approached, in another half hour, within good round-shot range, I threw a 32-pounder near enough to her stern to give her captain a shower bath. In a moment more we could see the stars and stripes ascending to the stranger's peak, the mainyard was swung aback, and the prize had surrendered herself a prisoner. She proved to be the Alert, of and from New London, and 


\section{Tales of Whalers in the Civil War $38 \mathrm{I}$}

bound by way of the Azores and Cape de Verde Islands to the Indian Ocean. She was only sixteen days from port, with files of late newspapers; and beside her own ample outfit for a large crew and a long voyage, she had on board supplies for the group known as the Navigators' Islands, in the South Indian Ocean, where among icebergs and storms the Yankees had a whaling and sealing station.... We paroled the officers and crew of the Alert and sent them ashore in their own boats as we had done the others.

"I now had three prizes on my hands, and as I could make no better use of them, thanks to the unfriendly conduct of neutrals, ... . we had three funeral pyres burning around us at the same moment. The other whalers at a distance must have thought that there were a good many steamers passing Flores that day. There was more work for us ere night set in. Another sail was discovered standing in for the island. We proceeded to meet the stranger, who was standing in our direction. The ships approached each other very rapidly, and we soon discovered the new sail to be a large schooner of unmistakable 
382 The Story of the New England Whalers

Yankee build and rig. . . . Upon being boarded she proved to be the Weathergauge, a whaler of Provincetown. . . . We now landed the crew of the Weathergauge in their own boats, with the usual store of provisions and traps, and burned her. Two days elapsed now without a capture. On the third day the welcome cry of 'Sail ho!' again rang from the masthead, and on making sail in the direction indicated by the lookout, we soon discovered the chase was a whaler. And in an hour or two more we were alongside of the American whaling brig Altamaba, from New Bedford, five months out. The Altamaba had had but little success, and was comparatively empty. She did not make so beautiful a bonfire, therefore, as the other whalers had done."

As one chase was very much like another, it will suffice to say here that the next whaler taken was the Benjamin Tucker, of New Bedford, with 340 barrels of oil on board. She was fired at to o'clock in the morning. The schooner Courser, of Provincetown, was the next victim. She was burned in the forenoon, also, after which the crews of the three ships last mentioned were sent 


\section{Tales of Whalers in the Civil War 383}

ashore in their own boats. The Virginia was the next whaler captured, and of her Semmes says:

"The torch having been applied rather late in the afternoon, the burning wreck was still visible some time after nightfall." This, according to his account, was the only ship that might have served to toll on the unwary whalers of the vicinity at night, and as a matter of fact none came within sight in consequence of her flames.

The most important of the Confederate cruisers, in the whalers' point of view, was the Shenandoah. Lieutenant John M. Brooke, of the Confederate navy, had seen service in the northern Pacific while in the United States Navy, and from his knowledge of the whalers he worked out a scheme for raiding the fleet near Bering's Strait. A British steamer, renamed the Shenandoab, was fitted for this service under Lieutenant James Iredell Waddell.

On his way to Bering's Strait, Waddell stopped at Ascension Island, and found in the port four whale ships, of which three were American and one was under the Honolulu flag. The cruiser's boat having brought all the whaler captains to 
384 The Story of the New England Whalers

the Shenandoab, Waddell told them their ships were confiscated to the Confederate government.

"Well, that's pretty quick done," said Captain Chase, of the Hector.

"None of your impertinence to an officer of the Confederate navy," said Waddell.

"I'm not impertinent," said Chase; "but it's pretty quick done, just the same."

For that remark, Waddell ordered the whaler placed in double irons and "gagged for disrespect," according to the log of the Shenandoab; but as a matter of fact the officer who was ordered to do the gagging did not do it.

Later Waddell made an effort to induce Captain George O. Baker, of the Edward Cary, to join the Shenandoab's crew, for she was short of men. Captain Baker says he enjoyed life and free drinks for several hours, while Waddell was explaining the situation, but when he finally refused to join her he was put in double irons.

On leaving Ascension (April 13, I865) the Shenandoab went to the Okhotsk Sea and Bering's Strait region. Between the 27th of May and the end of June she captured twenty-four whalers 


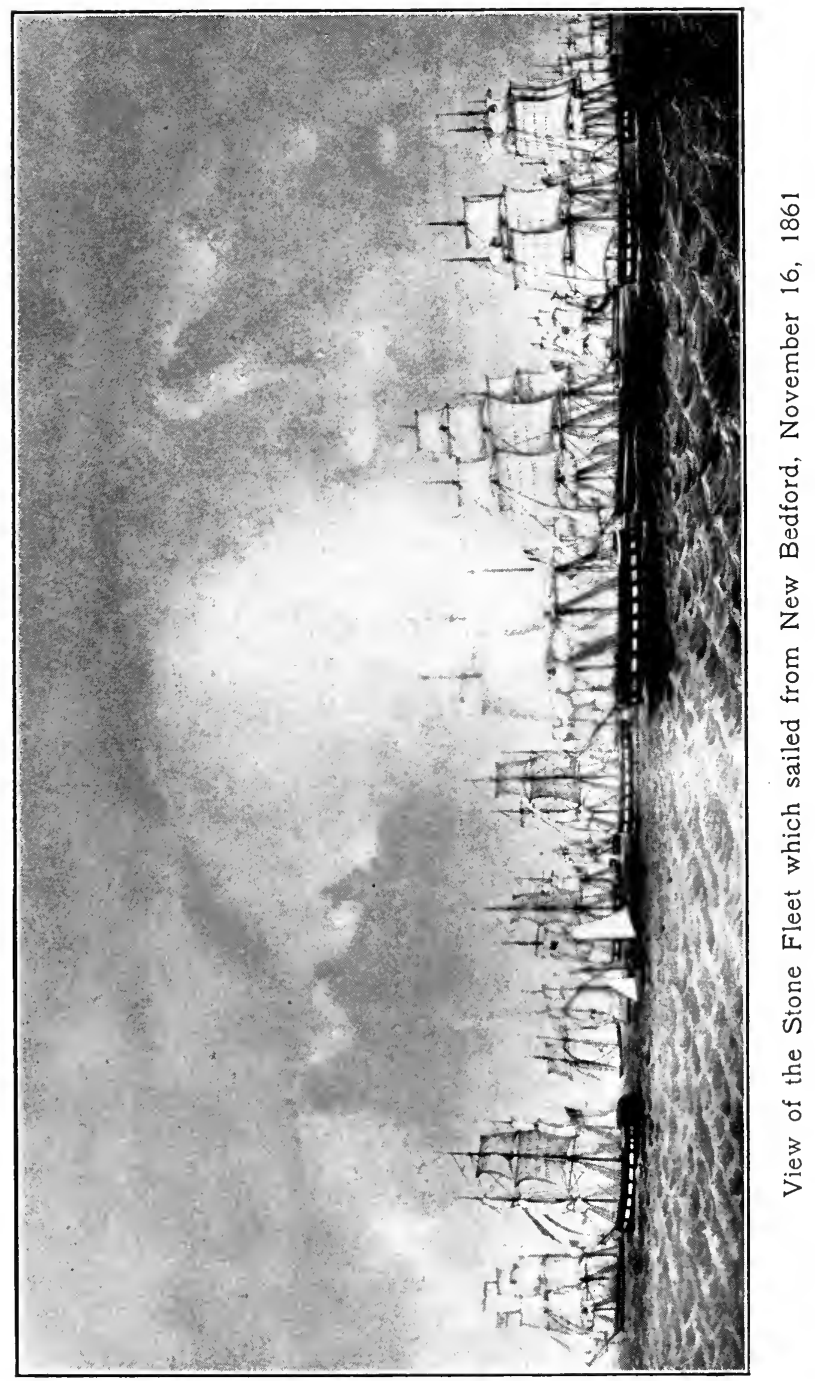



Tales of Whalers in the Civil War 385

and one trader. On June 22 five whalers were taken, among them being the Milo, the captain of which told Waddell that the war was ended. As the Milo had no papers on board to substantiate the statement, Waddell refused to believe it. The Milo was bonded for $\$ 46,000$, her master agreed that the owners would pay that sum to the cruiser's commander within six months after the independence of the Confederacy was acknowledged by the United States. She was then released to carry home the crews of other whalers which were burned. One ship was taken on the $23^{\mathrm{d}}$ of June and another on the 25 th, and then on the 26th six more were secured. All the eight were destroyed. On the 27th the trader Susan Abigail came to the Shenandoab, wholly unaware that she was in any danger. She had sailed from San Francisco on April 19, and had on board files of newspapers to that date. These papers told of the surrender of General Lee and the Confederate army of Northern Virginia; of the occupation of the Confederate capital by Federal troops; of the flight of President Davis and his cabinet. Fort Fisher, at Wilmington, 
386 The Story of the New England Whalers

North Carolina, had long since fallen, and Charleston, South Carolina, had been captured. Sherman had been pressing the Confederate army under Johnson (the last of the Confederate armies) so closely that Johnson had asked (April I4) for a cessation of hostilities, "the object being to permit the civil authorities to enter into the needful arrangements to terminate the existing war." (Johnson's letter.) The war was, in fact, ended, but no formal proclamation of the ending of hostilities had been made, and Waddell continued his work of destruction. The Susan Abigail was burned. On June 28 eleven whalers were captured, of which two were bonded to carry the crews and the others were burned.

The Shenandoab now turned southward, and on August 2 fell in with the English bark Barracouta, "from San Francisco to Liverpool, thirteen days out. Having received from the Barracouta the sad intelligence of the overthrow of the Confederate government" (quoted from the Shenandoab's $\log$ ), the cruiser was taken to Liverpool and there surrendered to the British authorities, who turned her over to the United States. 
Tales of Whalers in the Civil War 387

Among the whalemen captured by the Shenandoab on June 27 , especial mention must be made of Captain Thomas G. Young, of the bark Favorite, of Fairhaven. When he saw that the cruiser was really an enemy, he loaded his whaling guns and such muskets as were on board, hoisted the old flag, and mustered his crew for a fight. He then took his station on the roof of the cabin and when the boat from the Shenandoab approached to demand his surrender, he shouted:

"Boat ahoy!"

" Ahoy!" responded the officer in charge, to quote the story as told in Hunt's T be Shenandoab.

"'Who are you, and what do you want?" was his next salutation.

"We come to inform you that your vessel is a prize to the Confederate steamer Shenandoab.'

"'I'll be $\mathrm{d}-\mathrm{d}$ if she is, at least just yet, and now keep off or I'll fire into you!'

"The old Spartan began to squint along his bomb gun, and the men to handle their muskets in such a decidedly businesslike manner, that it was perfectly apparent that he intended to carry his threat into execution. 
388 The Story of the' New England Whalers

"Seeing this the officer in charge of the boat hailed our ship, reported the state of things, and wished to know if it was the captain's desire that he should board in spite of resistance. Captain Waddell ordered the boat back to the Shenandoab, which immediately steamed towards the contumacious Yankee, and ranged alongside.

"The skipper still stood by his bomb gun with his forces drawn up on deck as though he actually meditated fighting it out.

"'Haul down your flag!' shouted the officer of the deck as soon as we were near enough for his voice to be heard on board the whaler.

"'Haul it down yourself, $\mathrm{G}-\mathrm{d} d-\mathrm{n}$ you, if you think it will be good for your constitution!' was the plucky response.

"'If you don't haul it down, we'll blow you out of water in five minutes.'

" "Blow away, my buck, but may I be eternally blasted if I haul down that flag for any cursed Confederate pirate that ever floated.",

A boat was now sent to take the whaler on board the Shenandoab. It was able to get alongside the whale ship without a fight solely because 


\section{Tales of Whalers in the Civil War 389}

her under officers had seen from the first that resistance was hopeless, and when loading the guns had omitted to put percussion caps on the nipples. Captain Young aimed his gun at the Confederates, but when he pulled the trigger the weapon was not discharged. To this statement Starbuck adds :

"His inhuman captors, who were unable to appreciate bravery, put him in irons in the topgallant-forecastle, and robbed him of his money, his watch, and even his shirt studs."

One might doubt Starbuck's statement but for the character that Hunt, quoted above (he was an acting master on the Shenandoab), gives Waddell. He says (pp. 262-263) that after the cruiser reached Liverpool, Captain Waddell deliberately swindled the Shenandoab's crew out of a large sum of money that had been placed in his hands by the Confederate agent for their use.

A brief, picturesque Civil War story of the whalers is that told of the Stone Fleet. An early move of the Federal authorities for the restoration of the Union was the blockading of the Confederate ports.' Exactly 185 harbor and 
390 The Story of the New England Whalers

river openings were to be closed absolutely against commerce. For this purpose three naval steamers and sixteen ships of the sail were available when the proclamations were issued, and the number of merchant ships that could be purchased and armed within reasonable time was limited. In the emergency some one in the Navy Department suggested that Charleston, the leading port of the Atlantic coast, might be closed by sinking stone-laden vessels in the channel. This plan having been adopted, Assistant Secretary of the Navy, Gustavus V. Fox, contracted with Richard H. Chappell, of New Haven, to supply forty-five vessels of any kind that could be floated to Charleston. As many old whale ships were then at the piers of New Bedford, Mr. Chappell went there and succeeded in buying twenty four. The prices paid for these whalers ranged from $\$ 3150$ to $\$ 6500$, a fact of some bearing upon the estimated amount of capital invested in whale ships during the Golden Era. The ships were bought as they lay at the piers with their whaling gear on board. This gear was sold, and many a fine bargain was obtained by the town's speculators. 


\section{Tales of Whalers in the Civil War 39I}

"As fast as each ship was emptied, she was fitted for convenient scuttling. About two inches above the light-water line a two-inch hole was bored in the counter, running completely through the side of the vessel. Into this from each side was inserted a plug turning to a loose fit and provided with a flange head sufficiently large to close the opening. These two plugs were bolted together by a bolt, passing through the centre, held by a head on the outside and by a wrench nut on the inside." At the proper time the nuts were unscrewed, the bolt knocked out, and the two plugs were allowed to fall out and let the water pour in. One James Duddy, having the contract for supplying the stone for the fleet, "started into the country and soon had all the farmers tearing down walls and loading stone on drays." So says the New Bedford Mercury.

Crews having been shipped for the voyage to Charleston, seventeen of the twenty-four were anchored in the bay below the city. The captains of this fleet then met and elected Captain Rodney French (he who had been convicted of fitting out the Margaret Scott as a slaver) as their com- 
392 The Story of the New England Whalers

modore. Said Captain J. M. Willis, one of the captains, in regard to this choice:

"When all preparations were made, we decided on Rodney French for commodore of the fleet. Rodney, who was afterwards mayor of New Bedford, was a pretty good fellow, told a good story, and was generally liked by the rest of the captains. There was only one of the captains who thought Rodney was not the man for the position."

On November 20, at 7 o'clock in the morning, the fleet weighed anchor and reached down Buzzard's Bay in a flock, piling on the canvas and racing like a fleet of yachts on a club cruise. They were bound for Savannah as a rendezvous, and the survivors yet tell with glee that the commodore's ship was the last to arrive because he took the coast route while the others reached offshore and held a good wind. On December I9 and 20 they gathered in the channel at Charleston, where Acting Master George H. Bradbury, of the frigate $W a b a s h$, located each ship. Then all were stripped of their sails and rigging, the masts were cut away on most of them, and, the 


\section{Tales of Whalers in the Civil War 393}

plugs having been knocked out, they all sank to the bottom.

An old war-time lithograph that is greatly prized by New Bedford people, and can be seen well framed in many houses there, is entitled: "View of the Stone Fleet Which Sailed from New Bedford Harbor." 


\section{XV}

\section{IN THE LATER DAYS}

"T TE never tire of telling the story of Captain George Fred Tilton," said Zepheniah W. Pease in his Pen Pictures of

Typical Whalemen, printed in the one hundredth anniversary number of the New Bedford Mercury. In 1898 the Bering Strait whaling fleet of eight vessels was caught in the ice off Point Barrow. The Belvedere was one of the fleet and Tilton was her mate. The month of October found the vessels still in the ice. The westerly wind blew steadily and the vessels were lying close together on the east shore. They were short of supplies, and the whalemen foresaw that unless they obtained help in some way before the arrival of the fleet of the next summer all were likely to perish. Every day was an anxious one. Finally the crew of the Fessie H. Freeman were awakened one night by the crushing of the ship, and the 
company of forty-nine men had barely time to jump for the ice before she was utterly destroyed. They went to the Belvedere. A few hours later the captain and fifty-five of the crew of the Orca came to the same ship and said that they had been forced to come by the destruction of their ship.

Various plans for reaching the open water were tried. Dynamite was used to open a way, but it failed to accomplish the desired result. When all means had failed, an accounting of the food on hand showed that since the supplies on the Freeman and the Orca had been lost, there certainly was no hope that all hands could survive until the next summer.

In this condition of affairs, Tilton offered to attempt to reach a shore whaling station on the southerly coast of Alaska whence supplies might be forwarded. The captains without exception flouted the suggestion, but Tilton said:

"It is our only hope. We cannot survive without assistance until summer. I have a fighting chance if I go, and scarcely that if I remain. If any one can make the trip, I can."

The latter assertion was a conceded point, 
396 The Story of the New England Whalers

and after a long consultation the captains gave a reluctant consent. At Point Barrow, Tilton got a sled drawn by eight young dogs and two Indian runners. The sled was fitted with a sail to ease the work of the dogs when the wind was fair. Such provisions as could be sparedprincipally hardtack - were given him, together with a map, a compass, a gun and cartridges, and a tent. Then on October 27 all the crews assembled to see him start. There were few who did not believe that he would soon perish in one of the blizzards that were fast coming on, and when he began his journey they cheered him until he was out of sight.

During the first day Tilton covered twentyeight miles, but never again was he able to do as well. The next day a storm kept the men in their sleeping bags all day. The third day Tilton lost his axe, which had been invaluable for cutting fuel and making paths. They subsequently found a knife in some deserted Eskimo huts, but it could by no means replace the axe. Then Tilton's feet and hands were frosted and on the twelfth day the wind blew the shelter tent away, leaving 
the men no protection, except that afforded by the sled which they turned up at night for a windbreak.

The wind in the mountains of Cape Lisburne was so fierce that it lifted the party from the trail. A few frozen fish were found, but on the fifteenth day the provisions gave out, then the dogs were killed, one by one, as food for the others. Days of starvation followed, but a village of Eskimos was found at Cape Hope, six hundred miles from the starting point of the journey.

Here a little food was secured, but the Indian guides deserted. Undaunted, Tilton prevailed upon an Eskimo man and woman to take their place and then went on for twenty-nine days, during which a single fish of small size per day was all the food the party had. At St. Michael's, as the station for which he was bound was called, the Farvis relief expedition was found, and to it was given needed information as to the best way to reach the whale ships. Then Tilton went on once more, constantly on the verge of starvation, until, on March 22, he arrived at the Kadiak Islands. Thus he was adrift in the Arctic through 
398 The Story of the New England Whalers

all that winter. At the Kadiaks he was able to secure transportation to San Francisco.

"If Tilton had been a professional explorer," says the Mercury, "the world would have proclaimed this marvellous achievement, and he would have been celebrated in books," but he "made nothing of it and reshipped for another whaling voyage."

Captain Tilton's adventure is made to serve as an introduction to this, the final chapter of the book, because the story of the whalers in the later years is to be found chiefly in the annals of the Arctic beyond Bering's Strait, - along the northwest coast of Alaska, where Tilton found his opportunity. On the whole, the story is one of disasters, and the greatest disaster of all was that occurring in the fall of 1871 , when thirty-four whale ships, and one trader from San Francisco, with crews numbering more than 1200 souls, were caught by the ice near Point Belcher, on the extreme northwest coast of the continent.

In all, forty-two whalers gathered at the edge of the ice early in May, I871, and worked their way north as the ice retreated or opened, until, 
at the end of June, they were able to pass through the strait into the Arctic Ocean. During July all but one, the Oriole, Captain H. S. Hayes, followed the Alaska coast until within a few miles of Icy Cape, and finally, early in August, some of them were able to reach up past Wainwright Inlet, and almost to Point Belcher. During all this time they were never for a moment out of sight of the unbounded ice of the Arctic Ocean, save only when the fogs shut them in. The open water stretching along the coast was never more than ten miles wide at most; it was commonly no more than three or four, and it was in this narrow lead that the fleet worked along to the points mentioned. They were at anchor every night and sometimes for days at a stretch. The open lead was flecked over with cakes of loose ice which varied in size from that of a country schoolhouse up to that of a city block. In among these blocks of ice the whales appeared, now and then, jetting their vapory breath into the freezing cold air. Indeed, "green" lookouts sometimes mistook the spray of a wave that was dashed against the weather side of a 
400 The Story of the New England Whalers

cake of ice for the less familiar breath of a whale. It was (and it is yet) the custom to send the small boats cruising among these cakes of ice in search of whales. They pulled in among the cakes wherever they found room for their oars, and they followed the narrow leads or cracks in the main field itself.

The boats were lowered for this kind of work and sent cruising under sails and oars, hither and yon, on August II. Some had the luck to strike and kill whales which they were towing to their ships, while others were in pursuit of whales, when the wind suddenly shifted to the southwest, and the ice began to close in on boats and ships alike.

Some of the boats managed to pull clear, but many of them were caught in the leads through the pack. The crews of these boats were obliged to clamber,up on the ice and by means of lines hoist the boats up where temporary safety might be found. Then they began the slow work of tracking the boats across the ice toward the ships. In the meantime the ice was closing in around the ships. In haste the men on board 
got up the anchors and set such sail as was needed to keep the vessels ahead of the ice. In some cases the danger was so imminent that it was necessary to slip the cable. Only those who have seen Arctic ice can fully appreciate the scene or the hardships endured by the crews as they worked upon and in front of the irresistible ice-field.

In time, of course, the pack grounded, for field ice reaches down from three to five fathoms below the surface of the water; and because the ships were of shoal draft, and the gale was moderate (by the Arctic standard), the fleet was for the time safe. But the open water in which they were imprisoned was in no place more than half a mile wide, while the breadth was in places two hundred yards. Worse yet, it was certain that if the gale should increase, the' ice would be driven to the beach.

Nevertheless, no sooner did the ice cease its advance than every crew set lookouts once more, and every man was alert to respond to the old cry of: "Blow! blow! Thar she blows!"

For two weeks the crews worked the narrow 
402 The Story of the New England Whalers

water. They even went offshore on the ice and killed whales in the pocket-like openings found in the ice-field. Blow high or blow low, they were there for oil and bone, and they would neglect no opportunity that offered, merely because the ice was threatening.

On August 25 a strong northeast gale came. The whalers had been expecting it to come, and it released the entire fleet by driving the pack away to a distance of from four to eight miles. When the ice began to move off, the Eskimos flocked to the ships and told the captains that this was the last opportunity that would be offered for escape; but the captains laughed at the friendly warning. The whales were coming from under the ice in numbers greater than at any time during the season; moreover, another northeast wind was sure to follow the southwest gale which the Eskim.os said was due in a short time. In September they would pull out for home,- not sooner.

For four days the whalers prospered. Then the wind shifted to the southwest, as the Eskimos had predicted. It was not a bad gale at first, 


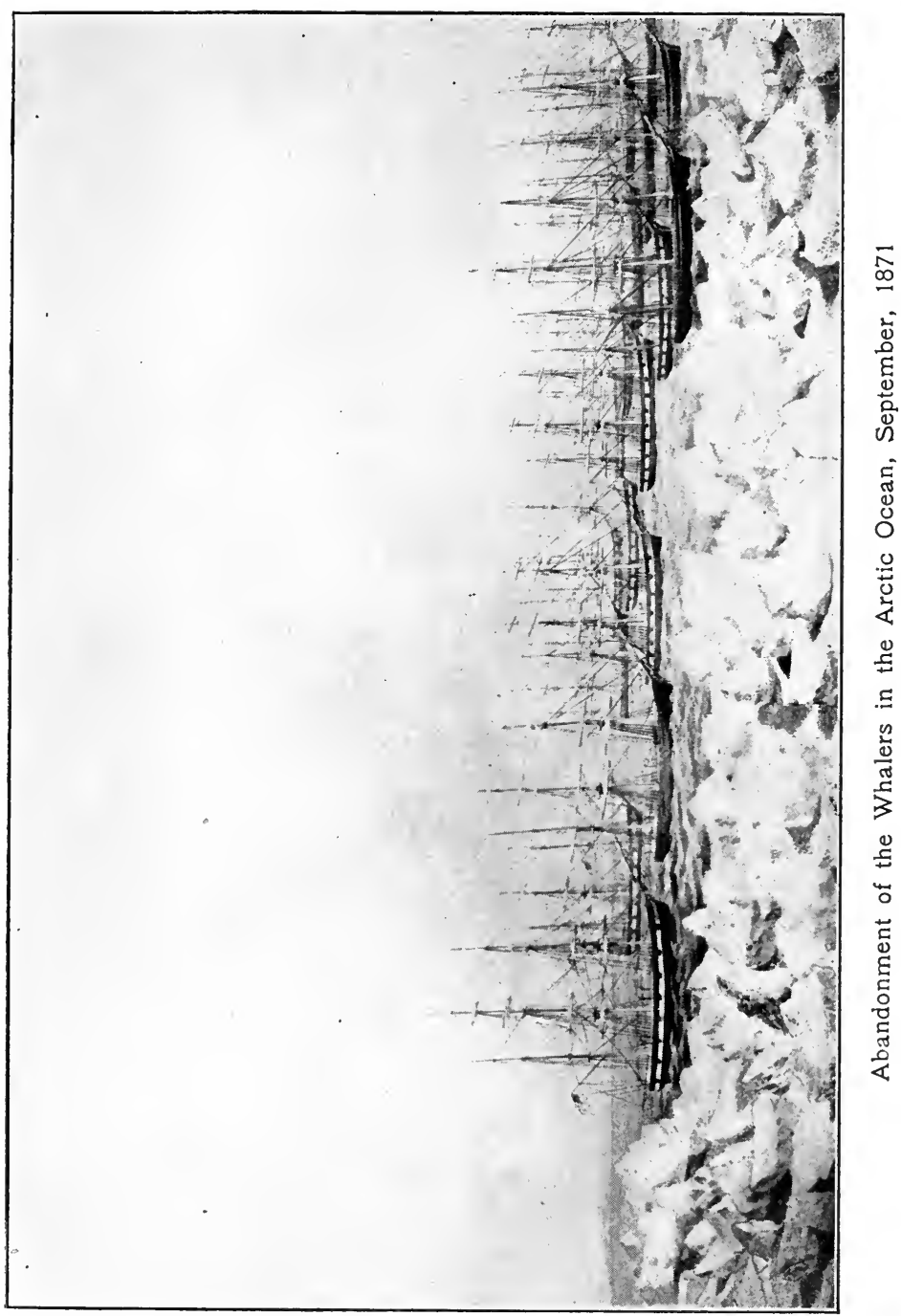



but on September 2 it came with a fury that was irresistible. The Comet, a ship that had faced the pack many a time, was caught between two huge floes and squeezed. Every frame was broken and her stern was forced out until it hung in a bulging mass above the ice. The crew fled to the other ships and were saved.

Some of the captains would now have been glad to up anchor for home, but it was too late; so they kept on whaling, hoping for a northeast gale. So it happened on the 7 th while the crew of the bark Roman were cutting in a whale, the ice began to swirl under the impulse of the wind, and it literally ground the old vessel to kindling wood. The next day the Awasbonks was destroyed in like fashion. The Awashonks was the vessel that, under Captain Prince Coffin, was attacked by the natives of Namorik Island away back in 1835 , with the result that Coffin, two mates, and four of the sailors were killed. Then under the impulse of the gale the ice began to rise up over the shoals near the beach, and all hands soon saw that it would certainly sweep across the beach itself before many days. 
404 The Story of the New England Whalers

At a consultation of all the shipmasters it was decided to send Captain R. D. Frazer, of the Florida, to explore such open water as was to be found alongshore to the south and west, the narrow lead between the beach and the icefield. He returned on the 12 th and reported the ice blockade solid, save for a lead just wide enough for small boats, to a distance of eighty miles from the fleet. Beyond the ice he had found seven whalers that were safe enough, and they, he said, would stand by until the crews of the beleaguered ships could reach them.

To cover eighty miles, even in the teeth of an Arctic gale, if that had been all, was no great hardship to old whalemen. But here were captains who had the savings of a lifetime invested in the ships they must leave, and every one in leaving his ship left the job by which he was supporting his family. Worse yet, some of the captains had their families with them. The women and children must be taken from the comfort afforded by stanch ships into the open boats where, drenched with the freezing spray which the gale would throw over them at every 
plunge of the bow, they must endure life as well as they could in the journey down the long, narrow lead.

Beginning at the stroke of the bell at noon on September 14, every ship set her ensign, with the union down. Then the crews climbed over the rails, helped the women and children down ladders to the boats, and when all -were ready the whole flotilla, numbering nearly two hundred boats, bearing I2I9 souls, headed away down the lead.

"It was just 4 o'clock when we shoved off from the Victoria," said Captain Davis, one of the unfortunates, in relating the story to the writer. "The sleet and snow were flying around us, and the blasts of wind that swept across the ice-fields made nothing of flannels and oilskins; but there was nothing else to do but pull away at the oars, as best we could, the whole night long. When daylight came we were strung along the open streak in a procession like the geese I was telling you about. Some were rowing, some were paddling, some had cails set. Between the snow and sleet squalls we could see the whole flotilla, but 
406 The Story of the New England Whalers

at times we couldn't see the next boat, though no further away than a ship's length.

"So we kept going, flinching when the squalls struck us, but thinking all the time about how much worse it was for them that had their women and children along. Of course we had food enough, - boiled beef and pork and bread that we'd made' ready before we left the ships, but we hadn't any coffee and we hadn't any way to make any. Along about four in the afternoon we saw on the beach a considerable lot of driftwood and with that we couldn't stand it any longer without the coffee. We pulled ashore and the rest followed."

Huge fires were built and the boats were drawn up and turned on edge to make shelters. With a number of sand-dunes found there to help break off the wind, the company became almost comfortable. Supper, with plenty of hot coffee, was prepared, and when that was eaten, everybody went to sleep in spite of the sleet-laden gale and the outlook for the morrow. Next morning, after a hastily eaten breakfast, all went afloat and toiled on. 
A few hours later the waiting ships were seen. It was necessary to pull out around a ten-mile tongue of ice that lay between them and the ships, but this was accomplished in spite of the tremendous sea that they met on the weather side of the point, and just sixty hours from the time of leaving the Victoria, Captain Davis was beside the Progress, Captain Dowden.

"When we got alongside I climbed up. I used to go to school with Captain Dowden," said Captain Davis.

"' Hello, captain,' says I.

"'Hello, Bill,' says he. 'I guess you want to stay, don't you ?'

"I did.

"'Well, I've got 220 on board now. You'll find better accommodation on that other ship down to leeward.'

"I went to the lee rail. 'Boys, pass up that grub and bear a hand about it, and then throw off the painter,' I said.

"They just humped themselves, and the boat was soon adrift. Then I walked aft to the captain again. 
408 The Story of the New England Whalers

“'Captain,' says I, 'I was just down to the rail to see about going off to the other ship, but some one had cast off the painter and there she goes now.'

"So we stayed. The fleet of seven vessels waited until the next day, and we counted up around, after a fashion, to see that none was left, and then made sail for the Sandwich Islands.

"It is the habit of the New Bedford owners to go to the Sandwich Islands every fall to meet the fleet and audit the accounts. It is a pleasant excursion for them, and it is good policy to attend to the business in person. It took us thirty days to get there. The owners were down on the beach to welcome. Instead of casks of oil and stacks of whalebone we discharged 1200 sailors, penniless, and with only one shift of clothes each, before the expectant owners."

When the whaling fleet returned next year (of course 'a fleet did return. Twenty-eight American and four foreign whalers went there), they found one of the abandoned vessels, the Minerva, afloat in Wainwright Inlet, as sound in hull as on the day her crew left her. All the 
others had been crushed, or stranded, or burned by the natives. This ship had served, during the winter, as a home for one sailor, who had braved the danger in the hope of making a fortune by saving bone from the abandoned ships. He secured a plenty of the bone, but the Eskimos would not let him keep it; in fact, they would have killed him but for the pity of their women, who hid him when the murderous mood was upon them. When spring came, he was glad to escape to the fleet empty-handed. The Minerva was manned and taken south. She was eventually sold and used as a freighter to carry oil from the Sandwich Islands to New Bedford.

In 1876 twelve ships were caught by the ice. "Several men perished in journeying from one beleaguered vessel to another, apparently more safe, and many died on the toilsome, perilous march to the rescuing ships. ... Fifty-three remained" with the ships, rather than risk the journey alongshore in search of ships that were clear of the ice, and three hundred escaped. The men who remained "were unequal to the exertion necessary to save their lives," says Goode's Whale Fishery. 
410 The Story of the New England Whalers

The story of the Oriole, mentioned above as a ship that did not follow the fleet, gives a good idea of what one may call the every-day work and losses of Arctic whalers. Captain H. Hayes commanded the Oriole that year, and Captain Davis was his mate. Hayes was one of the most enterprising captains of the Arctic fishery. $\mathrm{He}$ put the Oriole into the ice ahead of all others, and having found open water near the Siberian coast, he reached away toward Plover Bay.

"There, I guess we've got the best of them all this time," he said as the Oriole cleared the ice, and so he had, for there was not another ship in the open water, nor likely to be for some time. He expected to have the schools of whales to be found near Plover Bay all to himself.

As the day wore away a cake of ice, as big and rugged as a New England pasture, was seen ahead, and the captain pinched his ship up into the wind, hoping to pass to windward of it. Finding, after a time, that this could not be done, he told the man at the wheel to "Let her go off." Off she went as merrily as the bird whose name she bore, and in a few moments she was ploughing 
down toward the lee of the big cake of ice. When she arrived at the corner the captain waved his hand toward the man at the wheel as a signal to put the helm down and bring the vessel to her course again. The man did as ordered, but the captain was a bit vexed because he had been obliged to veer off, and it seemed to him that she was not coming to the wind as rapidly as she should have done. Turning around he said to the man:

"Consarn it, put that wheel down."

The man put the wheel hard down immediately, and before any one realized what was doing the bark was shaving along within a boat's length of the huge cake.

"Ease her off a little!" shouted the captain, and the man was obeying this order when she struck on a point of ice projecting under water like the ram of a man-of-war, and with a force that almost threw her on her beam ends.

"By thunder!" said Mr. Davis; "if she gets many more blows like that, we'll be in the boats."

As the vessel righted and continued on her way with speed unimpaired, no one gave the matter any more thought. That night, however, 
412 The Story of the New England Whalers

one of the boat steerers had occasion to go into the hold for some kind of gear for his boat. Opening the hatch he went backing down the ladder for a few rounds, and then, turning quickly, he climbed up again, shouting:

"Captain Hayes, yer ship's full of water clean up to the deck beams."

This was almost true, but by manning the pumps and rigging barrels in slings to bail her the crew managed to lower the water until they could get at the leak. The ice had made "basket work" of a large space on the bluff of the bow, but they covered the wound with oakum, canvas, etc., in a way that stopped the inflow of water for the time being, and then they sailed her to Plover Bay, where they laid her alongside a steep beach, discharged the cargo of all kinds, sent all upper spars on shore, and hove her down. The leak on the port side of the bow, where she had struck the ice, was soon repaired. At the same time, however, it was seen that some damage had been done on the starboard side. They therefore righted the ship, turned her around, and hove her down again. But just when she 
was down to the right angle, and the carpenter's gang were ready to go to work, the after-hatch broke in under the pressure of the water, for nearly half the deck was below the surface as she lay on her side. In three minutes she was on the bottom with only her mastheads out of water.

"There," said Captain Hayes, "now we've done it for keeps." It was so. Nothing they could do would raise her.

Hard as was the life of the whaler in the Arctic, there was a pleasant side to the picture, now and then. Even these castaways from the Oriole made shift to enjoy themselves in spite of the loss of the ship. The stores were on shore.

- The natives had been hired to help with the work on the ship. They had received some rum and liberal supplies of bread and molasses, which they liked almost as well as rum. They now proved good providers of Arctic game, and the crew went hunting for themselves, so that life was by no means all hardship while they waited for another ship to appear. The trader Victoria, mentioned above, was the first vessel that came to the rescue. When she had finished her trad- 
4I4 The Story of the New England Whalers ing with the Siberians she went over to the Alaska coast and thus had the misfortune to get caught with the whaler fleet of that year.

Captain Davis said that even when the ice was coming in over the shoals on the Alaska coast, just before all hands were driven from their ships, the officers of the fleet, instead of bewailing their fate, managed to get some comfort out of life by going ashore, from day to day, and shooting wild fowl. The fall migration was at its height, and as Captain Davis described the flight, the geese were so numerous that they formed an almost unbroken procession "a few rods wide and just as long as your eye could reach. That sounds like a fish story, don't it? Well, it's the truth, just the same. They were lower down than the eaves of a four-story house, and there was scarcely a break in the procession large enough to see a church steeple through, always supposing that a church steeple had been there," said the captain. "The number of wild fowl killed was so great that, on the Victoria, at least, the men got tired of them, and were glad to get back to salt pork and beef." 
With the growth of the importance of the Arctic whaling, due to the decline in the price of oil and the increase in the price of bone, San Francisco became the real home port of the American whaling fleet, though to this day more whalers are registered at New London than at the Pacific port.

The first whaler to sail from San Francisco was the Popmunnett. She cleared out for a sperm voyage in 1850 . During thirty years thereafter, however, no more than eight whalers were registered there in any one year. In the meantime, a coast whale fishery was established in California, beginning at Monterey in $185 \mathrm{I}$. The habit which certain whales then had of visiting sheltered waters of California and Lower California (Magdalena Bay, for instance), to bring forth their young, and the migrations along the coast, gave a great impetus to this fishery. But the whales were nearly exterminated, and with decreasing production came decreasing prices. Neither the Arctic nor the coast fishery could make a whaler port of San Francisco, until after the destruction of sailing ships in the Arctic ice 
$4^{16}$ The Story of the New England Whalers

compelled the whalers to adopt steam. It was the use of steam that made San Francisco a popular port with whalers, in the first place. Then it was seen that the shipment of the crude oil across the continent was a large and, to a great extent, a needless expense. In 1883 "extensive works for the manufacture and sale of whale and sperm oil" were erected at that port, "thus enabling the owners there located as well as others who import oil at that place to find a market without paying the heavy cost of shipping the same to the Atlantic seaboard."

(The Whale Fishery.)

The whale fishery fleet of 1883 numbered 125 all told, of which number nineteen were registered at San Francisco. Thereafter the fleet decreased steadily until I90I, when only forty American vessels were employed in the pursuit of whales. The last report of the Commission of Navigation shows that the fleet yet numbers forty, and that San Francisco owns eighteen of them, - twelve steamers and six ships of the sail.

The space allotted to this story is filled. We, the reader and the writer, have travelled far to- 


\section{In the Later Days}

gether; but the hold of our ship is "all chocked off," she is "full up to the hatch coamings." More whales might be caught, more stories might be told, but there is no room left for stowing any kind of cargo. We must pass the word, "All hands up anchor for home!" and strike up the chanty that was usually sung by the crews on such an occasion:

"We're homeward bound to New Bedford town;

Good-by, fare you well; good-by, fare you well;

When we get there we will walk around;

Hurrah, my boys, we're homeward bound.

"And now our ship is full, my boys;

Good-by, fare you well; good-by, fare you well;

We'll think of home and all its joys;

Hurrah, my boys, we're homeward bound.

"It's when you see those New Bedford girls;

Good-by, fare you well; good-by, fare you well;

With their bright blue eyes and flowing curls;

Hurrah, my boys, we're homeward bound.

"When we're paid off, we'll have a good time;

Good-by, fare you well; good-by, fare you well;

The sparking of girls and the drinking of wine;

Hurrah, my boys, we're homeward bound. 
418 The Story of the New England Whalers

"We'll spend our money free when we're on shore; Good-by, fare you well; good-by, fare you well; And when it's all gone, we'll to sea for more; Hurrah, my boys, we're homeward bound." 


\section{Stories from American History}

\section{Yankee Ships and Yankee Sailors}

\section{By JAMES BARNES}

Tales of 1812, by the author of "Drake and his Yeomen," "For King and Country," etc. Illustrated by R. F. ZOGBAuM and Carlton T. Chapman.

Cloth, $\$ 1.50$

\section{The Wilderness Road}

\section{By H. ADDINGTON BRUCE}

The central figure in this story of the early development of the Middle West is Daniel Boone, the man who blazed the famous Wilderness road. In telling his story Mr. Bruce touches on such matters as the economic and social factors influencing the movement across the mountains, and the significance of that movement with relation to the growth of revolutionary sentiment in the American colonies, etc. To be illustrated.

Cloth, $\$ 1.50$

\section{The Story of the Great Lakes}

\section{By EDWARD CHANNING and MARION F. LANSING}

The Professor of American History in Harvard University, author of a number of volumes on the History of the United States, has found an immense amount of romance centred about the Great Lakes, from the time of their discovery and early exploration by the French missionaries down to the present time when they play so important a part in the industrial progress of the Middle West. This book tells the story of these great inland waterways, with special reference to those picturesque aspects of history which interest the general reader. To be illustrated.

Cloth, $\$ I .50$

\section{The Story of Old Fort Loudon} By CHARLES EGBERT CRADDOCK

A Tale of the Cherokees and the Pioneers of Tennessee, 1760, by the author of "The Prophet of the Great Smoky Mountains." Illustrated by ERnest C. Peixotto. 


\section{Southern Soldier Stories}

\section{By GEORGE CARY EGGLESTON}

Forty-seven stories illustrating the heroism of those brave Americans who fought on the losing side in the Civil War. Humor and pathos are found side by side in these pages, which bear evidence of absolute truth. Illustrated by R. F. ZOGBAum.

Cloth, $\$ 1.50$

\section{Tales of the Enchanted Isles of the Atlantic}

\section{By THOMAS WENTWORTH HIGGINSON}

Legends showing that the people of Europe were for centuries fed with romances of marvellous and beautiful countries beyond the Atlantic. Besides the early Irish, Spanish, and other traditions of the Happy Islands of the West, there come to us, among others from our own race, the old stories of King Arthur and his Avalon; of St. Brandan's Isle; of the Voyages of Erik the Viking; and of the vanishing Norumbega, so real a vision to the imaginations of Queen Elizabeth's day. Illustrated by ALBERT HERTER.

Cloth, $\$ 1.50$

\section{De Soto and His Men in the Land of Florida} By GRACE KING

The author of "New Orleans: The Place and the People" has collected into an entertaining volume stories of the brilliant armada which sailed westward under De Soto in 1538 to subdue the natives and bring this country under the Spanish crown. Old Spanish and Portuguese narratives are the basis of its history. Illustrated by George Gibbs. 


\section{The Story of the New England Whalers} By JOHN R. SPEARS

Some of the most romantic and adventurous characters in American history are dealt with in this book, in which Mr. Spears tells the story of the American whaling industry. He has given us the life stories of the men who made New Bedford, Nantucket, and Marblehead the men to whom more than to any others was due the upbuilding of the American merchant service in the early days of the Republic. Illustrated from photographs.

Cloth, $\$ 1.50$

\section{Buccaneers and Pirates of Our Coast}

\section{By FRANK R. STOCKTON}

This book is an account - with efforts to sift falsifying legend and preserve the truth - of the offshoots of the early English, French, and Dutch combinations against Spanish exactions in West India waters. From the early buccaneer with a legitimate purpose came the pirate whose greed of booty was for private gain. Mr. Stockton has told wild stories of picturesque figures among both types of leaders, and his characteristic quaint turns of humor set them off entertainingly. Illustrated by G. VARIAN and B. W. Clinedinst.

Cloth, $\$ I .50$

PUBLISHED BY

THE MACMILLAN COMPANY 


\section{THEODORE ROOSEVELT}

The Boy and the Man

\section{By JAMES MORGAN}

\section{The New York Times Saturday Review}

heads its two-column-and-a-half review with the caption:

"THE IDEAL BIOGRAPHY OF MR. ROOSEVELT"

The Journal of Education, Boston, says :

"No other biography that has come under my eye will put as much iron into a young man's blood as this story. ... Buy it, read it, pass it along to others to read, and tell others to read it."

The Sacred Heart Review says:

"Whether or not a reader believes in Mr. Roosevelt's policies, we doubt if he can fail, after reading Mr. Morgan's book, to be a better American."

The book is not a eulogy, an analysis, or a criticism. It is a straightforward narrative, interesting in style, and admirably free from political bias. It is a book in which every man and boy in America is interested.

Illustrated with exceptionally fine portraits. Cloth, $\$ 1.50$

\section{THE MACMILLAN COMPANY}

POBLISHERS, 64 \& 66 FIFTH AVENUE, NEW YORK 
RENT 

(1)

H.

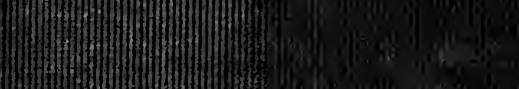

(1)

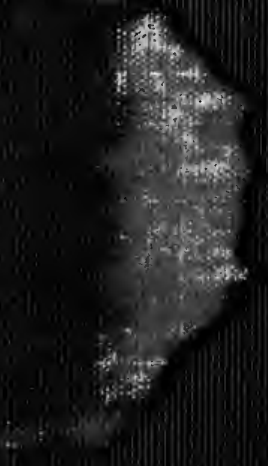

